\title{
Water-Quality Assessment of Steiner Branch Basin, Lafayette County, Wisconsin
}

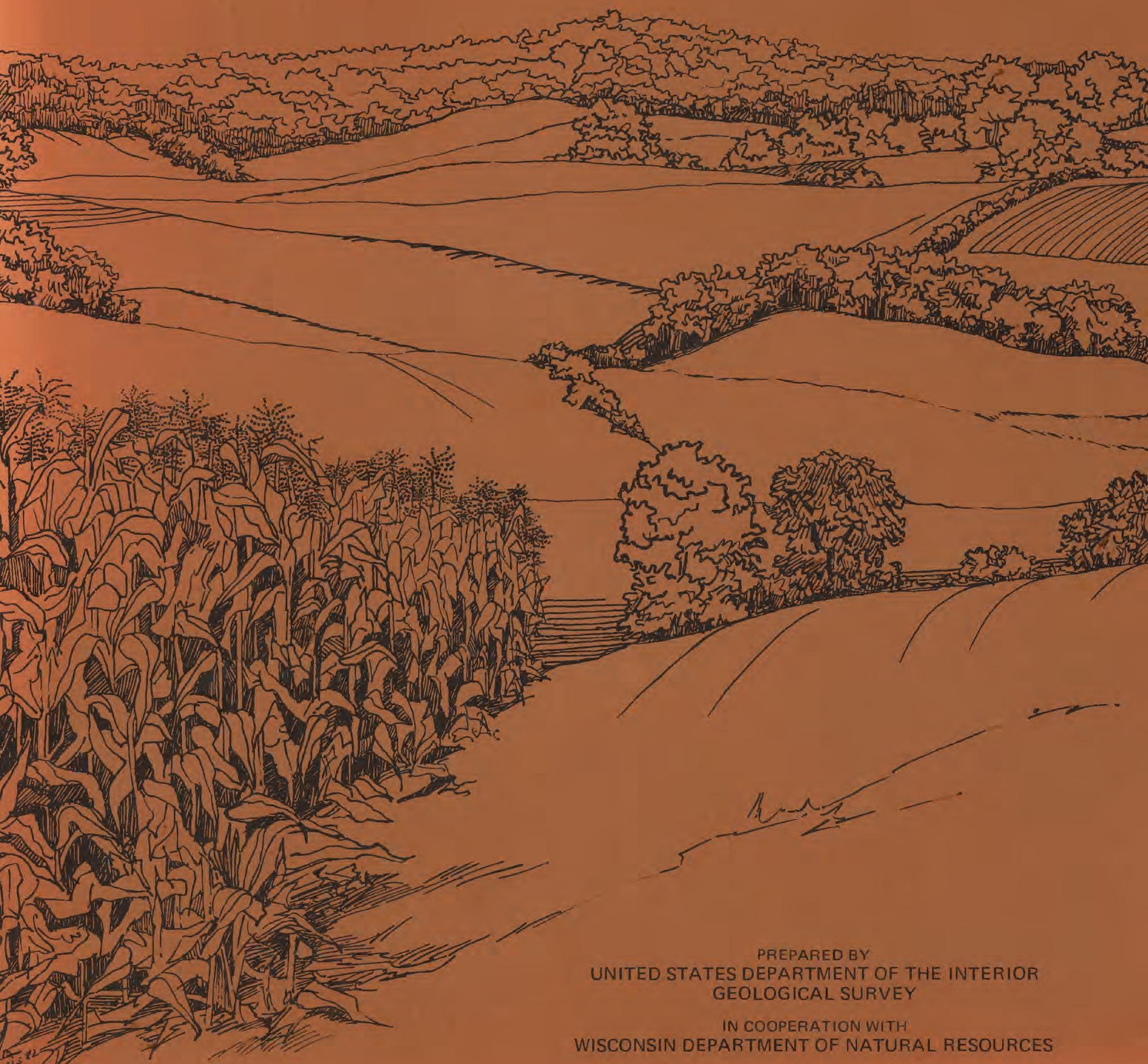




\section{Water-Quality Assessment of Steiner Branch Basin, Lafayette County, Wisconsin}

S. J. FIELD AND R. A. LIDWIN

U. S. GEOLOGICAL SURVEY

Water Resources Investigations 81-52

Prepared in cooperation with the

Wisconsin Department of Natural Resources 


\title{
UNITED STATES DEPARTMENT OF THE INTERIOR
}

JAMES G. WATT, SECRETARY

\section{GEOLOGICAL SURVEY}

\author{
Dallas L. Peck, Director
}

For additional information write to:

U. S. Geological Survey

1815 University Avenue

Madison, Wisconsin 53706 


\section{CONTENTS}

$\underline{\text { Page }}$

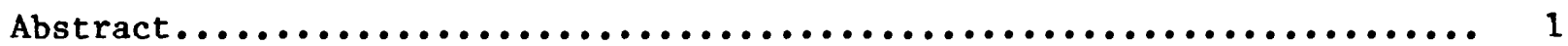

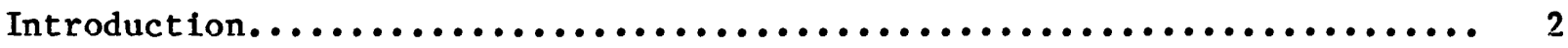

Physical setting....................................... 4

Geography............................................ 4

Topography........................................ 4

Vegetation........................................ 4

Stream-channel characteristics....................... 7

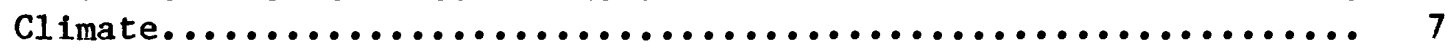

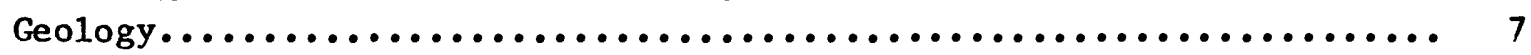

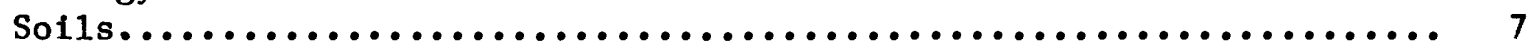

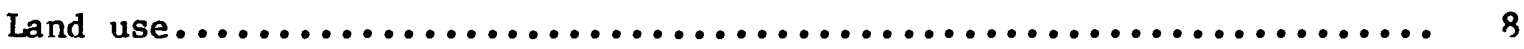

Sampling network and data-collection methods.................... 1n

Hydrologic conditions during study period....................... 11

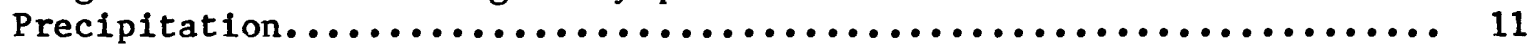

Ground-water levels................................... 13

Streamflow........................................ 13

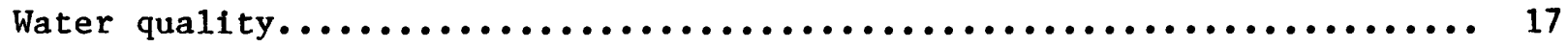

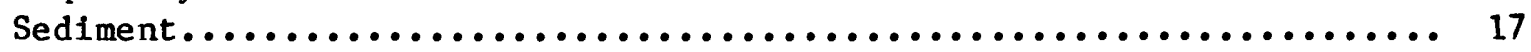

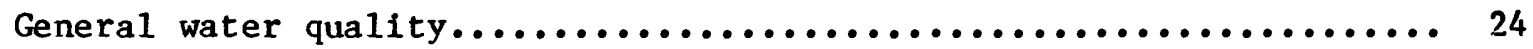

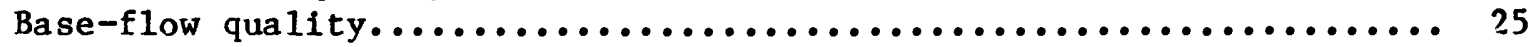

Water quality of selected storms........................ 27

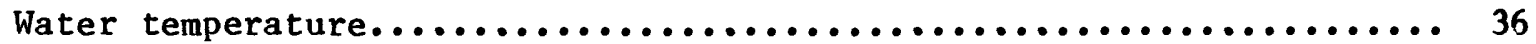

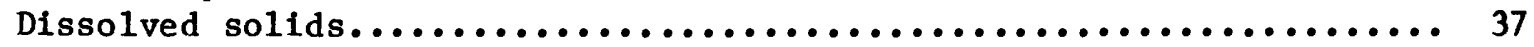

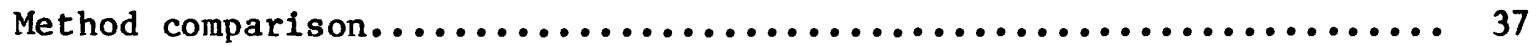

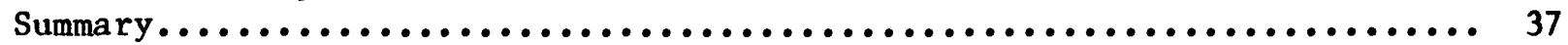

References................................................. 38

\section{ILLUSTRATIONS}

Figure 1. Map showing location of Steiner Branch and Yellowstone River basins in Wisconsin........................ 3

2. Aerial photograph of Steiner Branch basin............... 5

3. Topographic map of Steiner Branch basin................ 5

4. Map showing soil slopes in Steiner Branch basin............ 9

5. Graphs showing water levels in a shallow and deep we11...... 12

6. Hydrograph and precipitation for Steiner Branch, 1978 water year....................................... 14

7. Hydrograph and precipitation for Steiner Branch, 1979 water year....................................... 15

8. Hydrographs of the 1978 and 1979 water years for Steiner

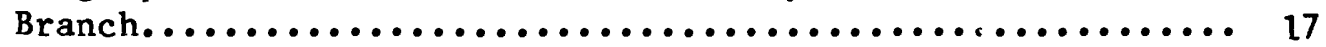

9. Map of precipitation for July 20, 1978, storm in the Steiner Branch and Yellowstone River basins................. 18 
10. Graph showing particle-size distribution of suspended sediment at Yellowstone River.......................

11. Graph showing stream discharge and suspended-sediment concentration for storms of June 16-17 and July 20-21, 1978

12. Hydrograph and constituent concentration graphs of the July 20-21, 1978, storm for Steiner Branch..............

13. Graph showing phosphorus, orthophosphate as a percentage of total phosphorus............................... 31

14. Graph showing constituent proportions of total nitrogen..... 32

15. Graph showing relation between chemical constituents and suspended sediment.............................

16. Graph showing double mass-accumulation curves for Steiner Branch for dissolved solids, suspended sediment, total nitrogen, nitrite plus nitrate nitrogen, and organic nitrogen versus stream discharge.....................

17. Graph showing double mass-accumulation curves for Steiner Branch for total phosphorus, ammonia nitrogen, and phosphorus, orthophosphate versus stream discharge........

\section{TABLES}

Table 1. Total precipitation and departure from normal, Dodgeville,

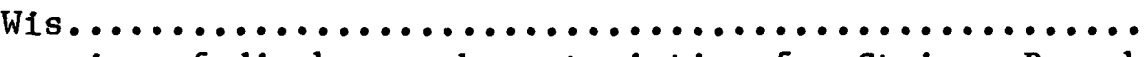

2. Summaries of discharge characteristics for Steiner Branch and Yellowstone River, 1978 and 1979 water years...........

3. Comparison of peak discharges of Steiner Branch and Yellowstone River................................

4. Suspended-sediment characteristics for Steiner Branch and Yellowstone River...............................

5. Daily suspended-sediment loads for days when the load was more than 25 tons at Steiner Branch, 1978 and 1979 water years...

6. Suspended-sediment data for Yellowstone River for period of record.......................................

7. Average yields, average concentrations, and percentage contribution of total yields of base-flow samples..........

8. Constituent loads and percentage of total yields for the 14

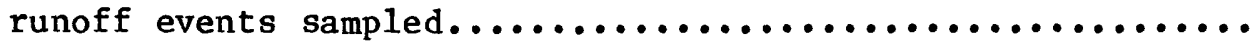

9. Average and maximum daily yields of nitrogen and phosphorus constituents for Steiner Branch.....................

10. Stream discharges for Steiner Branch, 1978 and 1979 water

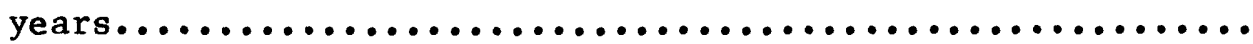

11. Stream discharges for Yellowstone River, 1978 and 1979

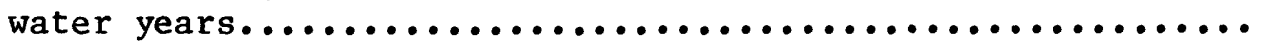

12. Suspended-sediment discharges for Steiner Branch, 1978 and 1979 water years................................ 43

13. Suspended-sediment discharges for Yellowstone River, 1978

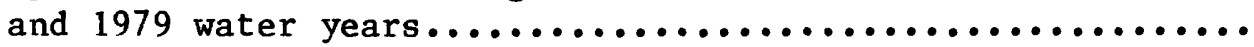


14. Total organic nitrogen for Steiner Branch, 1978 and 1979 water years.................................... 47

15. Total nitrogen for Stelner Branch, 1978 and 1979 water years.. 48

16. Total nitrite plus nitrate nitrogen for Steiner Branch, 1978 and 1979 water years............................ 49

17. Total ammonia nitrogen for Steiner Branch, 1978 and 1979 water years................................. 50

18. Total phosphorus for Steiner Branch, 1978 and 1979 water years...................................... 51

19. Total phosphorus, orthophosphate for Steiner Branch, 1978 and 1979 water years................................ 52

20. Water temperatures of Steiner Branch 1978 and 1979 water years..................................... 53

21. Specific conductance of Steiner Branch, 1978 and 1979 water years...................................... 56

\section{CONVERSION TABLE}

For readers who prefer to use SI units rather than inch-pound units, conversion factors for terms used in this report are listed below.

\section{Mu1tiply}

Inch (in.)

foot ( $f t$ )

mile ( $\mathrm{mi}$ )

square mile ( $\left.\mathrm{mi}^{2}\right)$

foot per $\mathrm{mile}(\mathrm{ft} / \mathrm{ml}$ )

ton per square $\mathrm{mile}\left(\mathrm{ton} / \mathrm{mi}^{2}\right.$ )

cubic foot per second $\left(\mathrm{ft}^{3 / \mathrm{s}}\right)$ degree Fahrenheit $\left({ }^{\circ} \mathrm{F}\right)$
By

25.40

0.3048

1.609

2.590

0.1894

0.3503

$2.832 \times 10^{-2}$

$0.555-(\mathrm{F}-32)$
To obtain

mil1imeter (mm)

meter (m)

kilometer $(\mathrm{km})$

square kilometer $\left(\mathrm{km}^{2}\right)$

meter per $\mathrm{kllometer}(\mathrm{m} / \mathrm{km})$

metric ton per square

kilometer $\left(t / \mathrm{km}^{2}\right)$

cubic meter per second $\left(\mathrm{m}^{3} / \mathrm{s}\right)$

degree Celsius $\left({ }^{\circ} \mathrm{C}\right)$

NOTE: The use of brand names in this report is for identification purposes only and does not imply endorsement by the U.S. Geological Survey. 


\title{
Water-Quality Assessment of Steiner Branch Basin, Lafayette County, Wisconsin
}

\author{
S. J. FIELD AND R. A. LIDWIN
}

\begin{abstract}
Steiner Branch basin in southwestern Wisconsin has rugged mature topography. Corn is planted in 30 percent of the basin on slopes ranging from 0 to 20 percent. Although contour stripcropping is a recommended practice for these easily eroded soil slopes, few conservation practices are followed to reduce soil losses. Because the stream drains into a manmade lake used for recreation, its water quality is of major concern. The purpose of this report is to assess the magnitude and types of nonpoint discharges that affect the water quality of Steiner Branch.

Total stream discharge for the 1978 and 1979 water years was 1,500 cubic feet per second per day and 1,800 cubic feet per second per day, respectively. The 1978 water year discharge was about 90 percent of the average and the 1979 discharge was 120 percent of average. During the 1978 water year, base flow was about 60 percent of the stream discharge, and in 1979 it was about 78 percent. Streamflow during the 2-year study period ranged from 1.5 cubic feet per second, which is approximately the low flow that occurs on the average of once every 2 years, to 392 cubic feet per second, a discharge of about a 5-year floodrecurrence interval.

Suspended-sediment yields were 369 tons per square mile in the 1978 water year and 84.6 tons per square mile in 1979. These yields were 1.66 times higher than those monitored in an adjoining basin where more typical conservation practices were employed. However, suspended-sediment yield per unit of stream discharge was only 1.30 times higher in the Steiner Branch basin than in the adjoining basin. The estimated long-term annual suspended-sediment yield for the Steiner Branch basin is 444 tons per square mile. Sediment concentrations in Steiner Branch ranged from 3 to 6,430 milligrams per 1iter.
\end{abstract}


Most of the nutrient load of the stream was transported during runoff: total organic nitrogen, 80 percent; ammonia nitrogen, 80 percent; total phosphorus, 84 percent; and total orthophosphorus, 77 percent. Transport of nitrite plus nitrate nitrogen and total nitrogen occurred primarily during baseflow conditions, with 75 and 56 percent, respectively, of the total load for the study period being transported during these conditions. The time distribution of total phosphorus, total orthophosphorus, ammonia nitrogen, and total organic nitrogen transport was very similar to suspended-sediment transport in Steiner Branch.

\section{INTRODUCTION}

In 1972, Congress mandated through Section 208 of Public Law 92-500, the Federal Water Pollution Control Act Amendments (FWPCAA), that the surface waters of the United States shall be "fishable and swimmable" by 1983 (92d Congress, 1972). To reach this goal, the states must identify and establish programs to improve water quality. It was evident that this water-quality goal could not be attained by regulation of point-source pollution only and that pollution from nonpoint sources could be major contributors to water-quality degradation (Donigon and Crawford, 1976).

The Wisconsin Department of Natural Resources (DNR) was designated as the State agency responsible for water-quality protection in Wisconsin (Wisconsin Department of Natural Resources, 1976) and had a primary role in meeting the FWPCAA requirements. However, to assess nonpoint-source input to water-quality degradation a data base must first be established. To assist in documenting an adequate data base, the U.S. Geological Survey, in cooperation with DNR, began a study in 1977 to define the water quality in relation to streamflow in basins that have pollution from nonpoint sources. The first basin chosen for study was that of Steiner Branch.

The purpose of this report is to present the magnitude and types of nonpoint discharges that affect the water quality of Steiner Branch. The scope includes determination of (1) the annual loadings of suspended sediment; (2) total nitrogen and phosphorus loadings associated with storms of varying magnitudes and seasons; (3) water temperature and dissolved solids; and (4) miscellaneous water-quality characteristics and constituents--dissolved oxygen, pH, biochemical oxygen demand, fecal coliform and fecal streptococcus bacteria, biomass, pesticides, trace metals, alkalinity, and chloride.

Steiner Branch is in Lafayette County $9 \mathrm{mi}$ west of Blanchardville in southwestern Wisconsin ( $\mathrm{fig}$. 1). Its drainage area is $5.9 \mathrm{mi}^{2}$ at the gaging station. During the study, approximately 30 percent of the basin was planted with corn on steep slopes, some in excess of 12 percent on which conservation practices to reduce erosion were few. Downslope from cropland, a wooded fringe in excess of 20 percent slope was common. It was suspected that, despite the buffer of natural cover, the combination of these conditions could produce high soil losses and significant pollution in the receiving waters. The water quality of Steiner Branch was of major concern because it is tributary to Yellowstone Lake, a manmade recreation lake. 


\section{EXPLANATION}

$\Delta$ Stream-gaging station and automatic sampling site

U.S. Geological Survey rain gage

National Weather Service rain gage

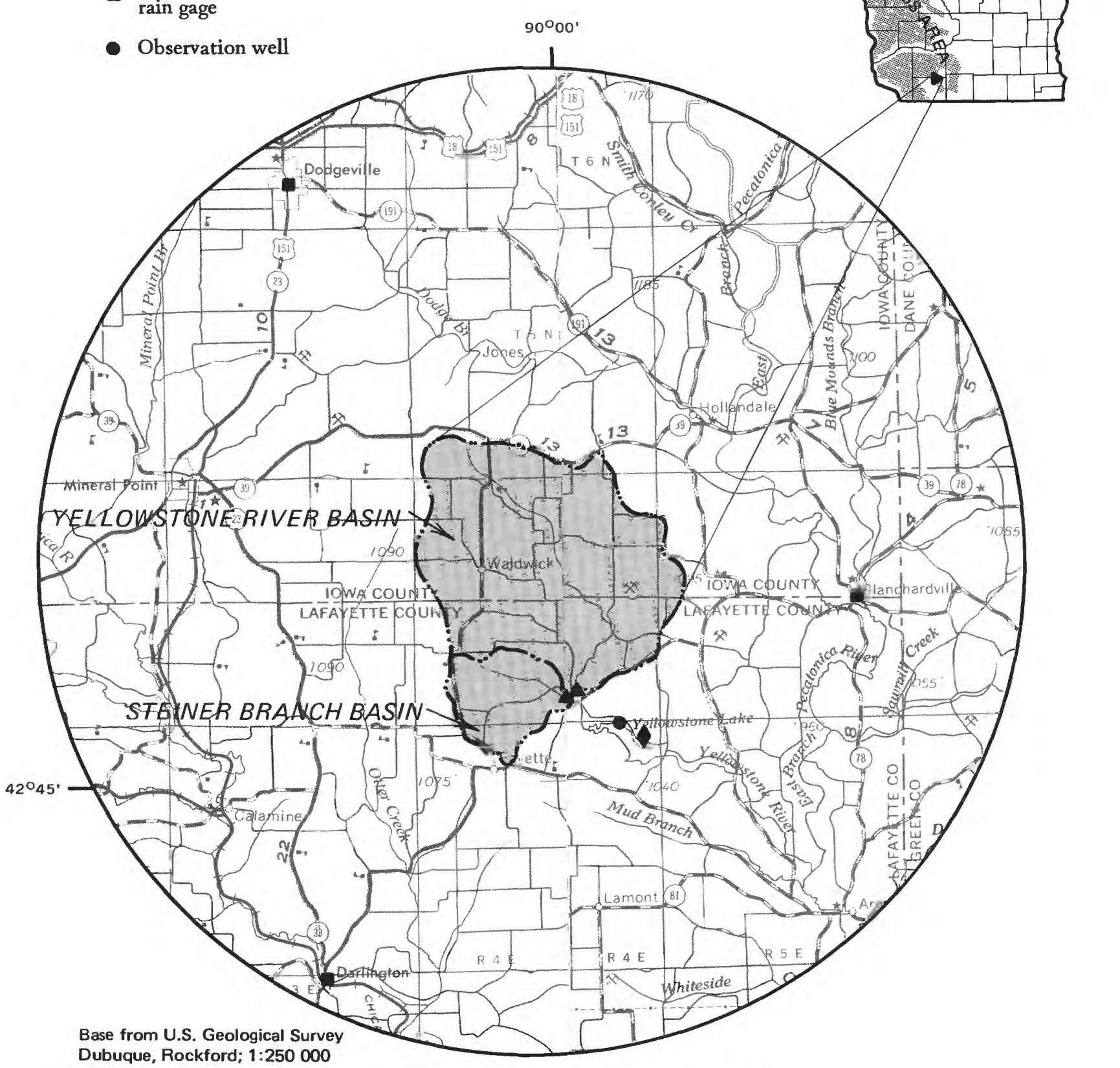

ord; 1:250 000

1958, revised 1971

SCALE 1:250000

0

Figure 1. Location of Steiner Branch and Yellowstone River basins in Wisconsin. 
Steiner Branch adjoins the Yellowstone River basin to the north (fig. 1), which is also tributary to Yellowstone Lake. In comparison to the monotypic corn cropping in the Steiner Branch basin, the Yellowstone River basin typifies the mixed agricultural uses of this historical dairy region. Although the Yellowstone River basin is not free of soil erosion and nonpoint water-pollution sources, the widespread adoption of contour stripcropping and other conservation practices expresses the high erosion risks and traditional concern for soil loss among the area's farmers. Figure 2 offers a partial aerial view of the contrasting pattexn in agricultural practices between Steiner Branch and its surrounding watersheds.

The Yellowstone River basin, which is reasonably typical of the regional land use, is adjacent to the Steiner Branch basin and, in addition, afforded the use of historical water and sediment-monitoring data. For these reasons, it was chosen as the control for suspended-sediment and stream discharge. The Yellowstone River was monitored for sediment discharge from 1955 to 1960 and for stream discharge from July 1954 to September 1965. The gaging station was reactivated simultaneously with the gaging station on Steiner Branch. The drainage area of the Yellowstone River basin upstream from the gaging station is $28.5 \mathrm{mi}^{2}$.

The authors wish to thank the Yellowstone Lake State Park personnel for their assistance in the data collection, especially Mr. Walter Johnson who serviced the samplers.

\section{PHYSICAL SETTING}

\section{Geography}

\section{TOPOGRAPHY}

Steiner Branch and the Yellowstone River basins have rugged mature topography characterized by well-developed dendritic drainage consisting of flat-bottomed valleys separated by steep-walled, slightly rounded ridges. The topography of Steiner Branch is shown in figure 3 and is similar to that in the Yellowstone River basin.

The altitude of the drainage divide of the Steiner Branch basin is about $1,120 \mathrm{ft}$, whereas that of the Yellowstone River divide is about $1,250 \mathrm{ft}$. The altitude of the streambeds of both streams at the gaging stations is $840 \mathrm{ft}$.

\section{VEGETATION}

The woodlands in both basins are generally on the steep valley walls, whereas agricultural cropping is on the ridgetops and valley bottoms. The woodlands are in the northern extension of the Central Hardwood Forest Region (Watson, 1966). The forest vegetation is classified as the oak-hickory forest type but is transitional between that type and the northern hardwood type. 


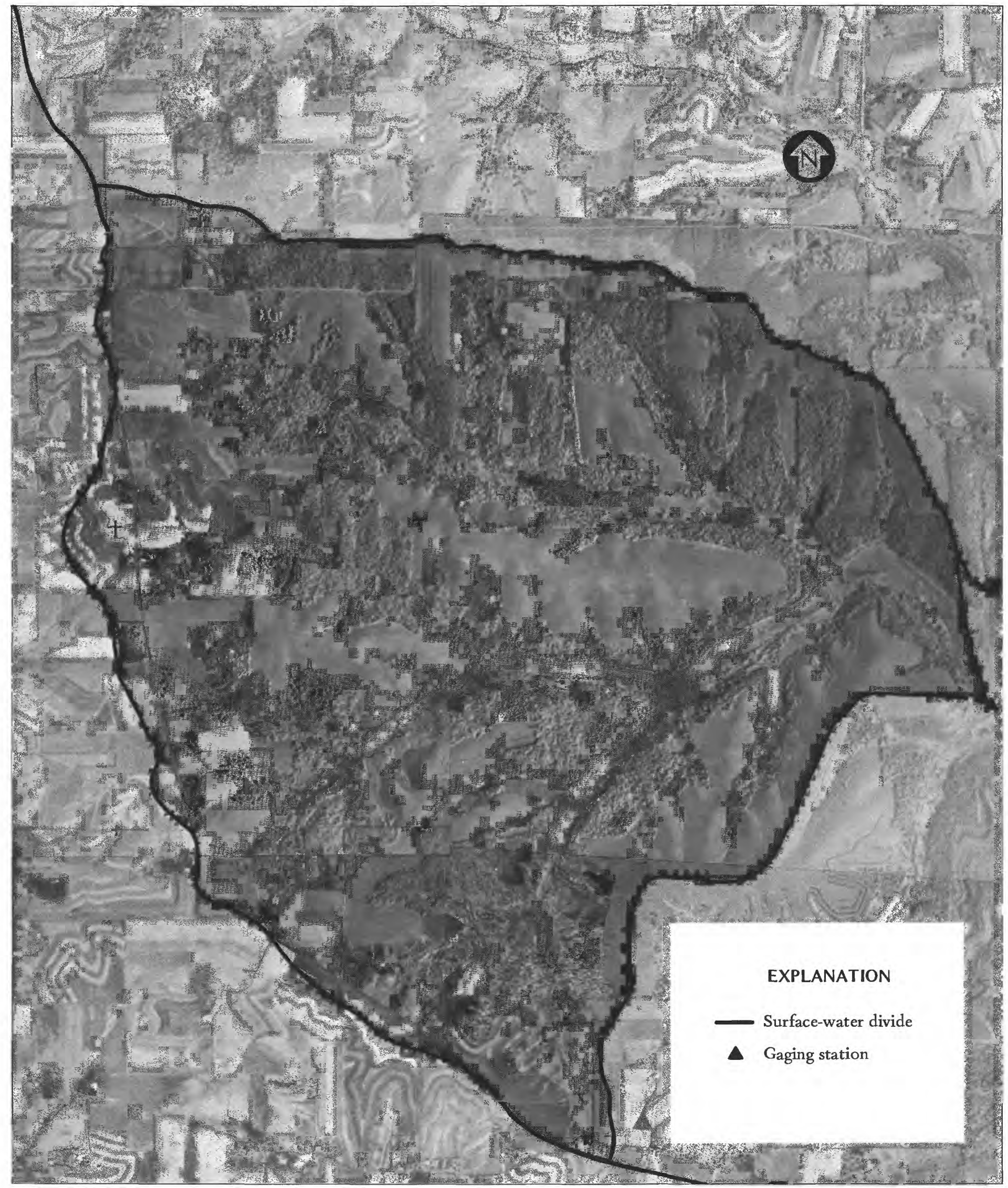

Figure 2. Aerial photograph of Steiner Branch basin. 


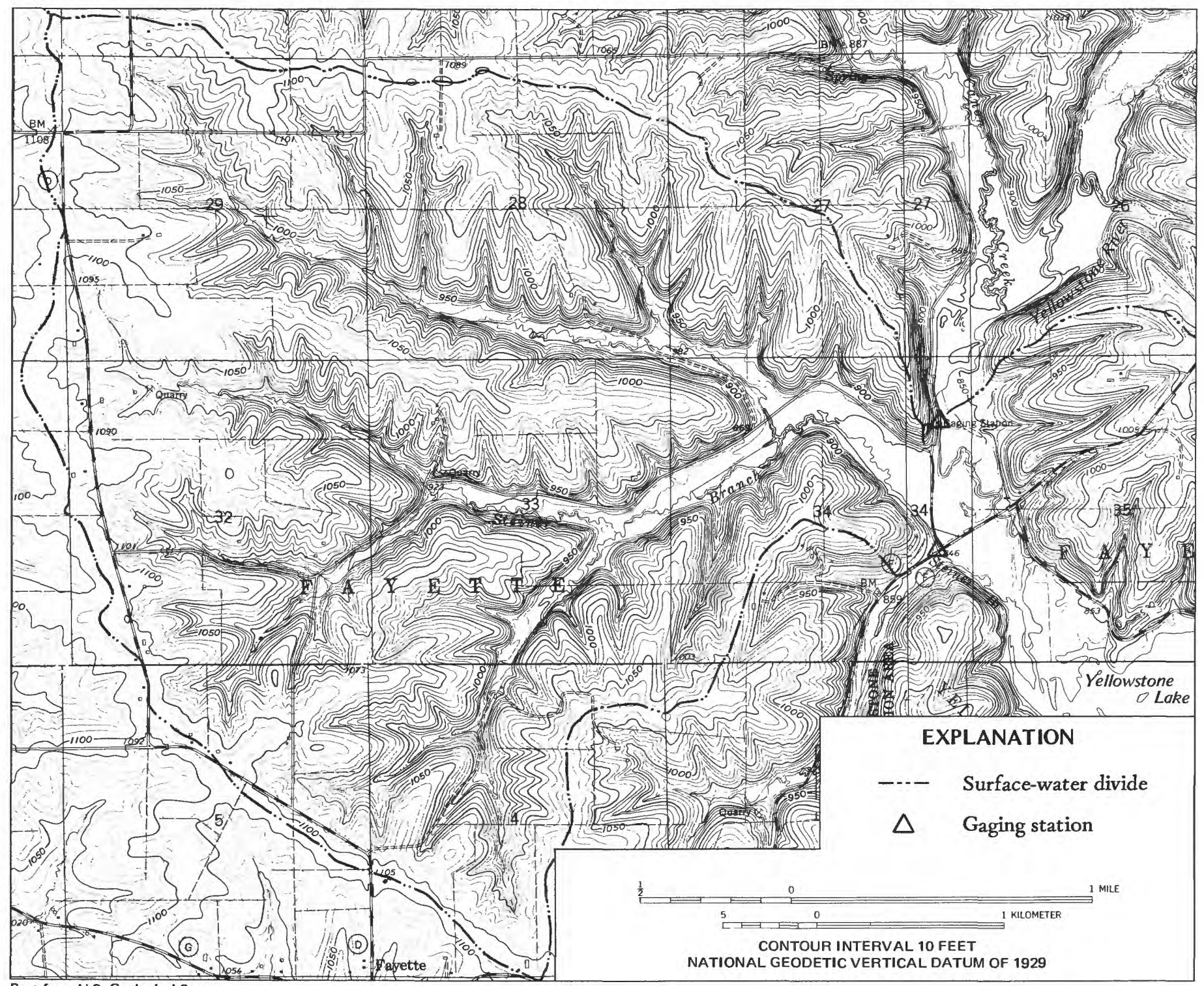

Base from U.S. Geological Survey

Waldwick, Yellowstone Lake,

1:24 000, 1962

Figure 3. Topographic map of Steiner Branch basin. 
The length of Steiner Branch from the drainage divide to the gaging station is $3.85 \mathrm{mi}$, with a gradient of $62 \mathrm{ft} / \mathrm{mi}$. The length of the Yellowstone River is $11.5 \mathrm{mi}$ from the drainage divide to the gaging station, with a gradient of $33 \mathrm{ft} / \mathrm{mi}$, or about half the gradient of Steiner Branch.

\section{CLIMATE}

The climate is a continental type and has four definite seasons (Wisconsin Department of Agriculture, 1961). Winters are cold and snowy, summers have periods that are hot and humid, and spring and fall are at times mixtures of both summer and winter. Temperatures, which are recorded $9 \mathrm{mi}$ to the southwest at Darlington, range from a mean monthly of $19.7^{\circ} \mathrm{F}$ in January to $72.2^{\circ} \mathrm{F}$ in July. The mean annual temperature is $47.1^{\circ} \mathrm{F}$. About 60 percent of the annual normal precipitation is concentrated from May through September. The average annual precipitation is 33.32 in. (1931-59) with February the driest month ( 1.04 in.) and June the wettest (4.88 in.). Snowfa11 averages 34.5 in. annually.

\section{Geology}

The Steiner Branch and Yellowstone River basins are in the "Driftless Area", an area of the State that probably was not glaciated during the Pleistocene Epoch (Thwaites, 1958). The predominant surficial bedrock in the basins are sedimentary rocks of Ordovician age. The Galena-Platteville unit (Galena Dolomite, Decorah and Platteville Formations, undifferentiated), mainly dolomite, forms the main bedrock of the undulating uplands and is underlain by St. Peter Sandstone. St. Peter Sandstone forms the bedrock in the lower part of the stream va1ley (Bean, 1949).

\section{Soils}

Solls of the Steiner Branch and Yellowstone River basins are silty clay loams and are described by Watson (1966) in Lafayette County and by K1ingelhoets (1962) in Iowa County. The uplands are covered by varying thicknesses of loessial material, whereas the valley bottoms are covered by moderately deep silty alluvium.

The Dubuque-Sogn series are the predominant soils, with the Dubuque soils dominant. The Dubuque soils are on gently sloping to sloping ridgetops and moderately steep to steep side slopes. These solls are in loessial material over red clayey material. Depth to the limestone bedrock ranges from 18 to 36 in. The Sogn soils are in small scattered areas on steep side slopes that border stream valleys. In these soils, depth to the limestone bedrock is less than 12 in. The erosion hazard for these soils is moderate to severe where the land is not forested.

The Arenzville-Orion soils are dominant on the nearly level lands along the stream bottoms. They are moderately deep soils formed in silty alluvium. The erosion hazard for these solls is slight to moderate. 
In the extreme west edge of the Steiner Branch basin, Ashdale soils are found on the uplands. These soils overlie a layer of red clay weathered from limestone, where depth to bedrock is 4 to $6 \mathrm{ft}$. The erosion hazard for these soils is slight to moderate.

In the northern and northwestern parts of the Yellowstone River basin, Dodgeville soils are on the upland ridges, are moderately deep to thin, and were formed in loessial material that overlies reddish clay weathered from limestone. The erosion hazard for these soils is moderate.

Land use

Agriculture is the principal land use in the Steiner Branch basin (Dave Kline, oral commun., 1979) which includes cropland, pasture, forest, and farmsteads. Few conservation measures to reduce soil loss are practiced in the basin. A September 1, 1978, aerial photograph by the Wisconsin Department of Transportation (fig. 2) shows little or no contour stripcropping. It also illustrates the sharp contrast between the lack of contour stripcropping in the Steiner Branch basin and its common use surrounding the basin and to the north in the Yellowstone River basin.

Soll slopes from the soil survey maps of the basin (Watson, 1966) are shown in figure 4. Large cornfields on the ridgetops are planted on soils where many soil slopes range from 6 to 20 percent. Soll slopes of these magnitudes require careful land management to control soil erosion (Watson, 1966). Figure 4 shows that many areas having soil slopes greater than 6 percent and most of the drainageways are forested.

Land use in the Steiner Branch basin was surveyed in 1978 and 1979 by the Lafayette County Soil and Water Conservation District (SWCD). The total amount of land in crops was $2.63 \mathrm{mi}^{2}$, or 45 percent of the basin. In 1978, corn was the predominant cash crop occupying, 28 percent of the basin, with hay, oats, and "government set aside" planted in the other 17 percent. The amount of corn in cropland increased slightly in 1979 to 31 percent of the basin with hay and oats occupying the other 14 percent. Erosion conditions of the cropland were determined as severe for $1.40 \mathrm{mi}^{2}$, medium for $0.74 \mathrm{mi}^{2}$, and low for $0.49 \mathrm{mi}^{2}$ (Clarence Keliher, written commun., 1980).

A field survey of land use in the Yellowstone River basin was not practical because of its relatively large size. Instead, land use was determined by Landsat imagery (Allord, 1979). An image taken May 9, 1976, indicated the basins to contain the following: forest, 41.4 percent; grass, 19.4 percent; bare soil, 15.0 percent; crop stubble, 10.8 percent; brush, 8 percent; wetlands, 1.2 percent; and water, 0.2 percent. Four percent was unclassified.

A similar determination of the land use was also done for the Steiner Branch basin. The land use values for the Steiner Branch basin were nearly the same as the land use values determined for the Yellowstone River basin. Due to the coarse resoltuion of Landsat imagery and the small size of the Steiner Branch basin, a Landsat classification may have some different results than a detailed field survey. However, the Landsat classification, in general, agreed with the field survey done by the SWCD assuming the bare soil, crop stubble, and grass categories represent land in crops. 


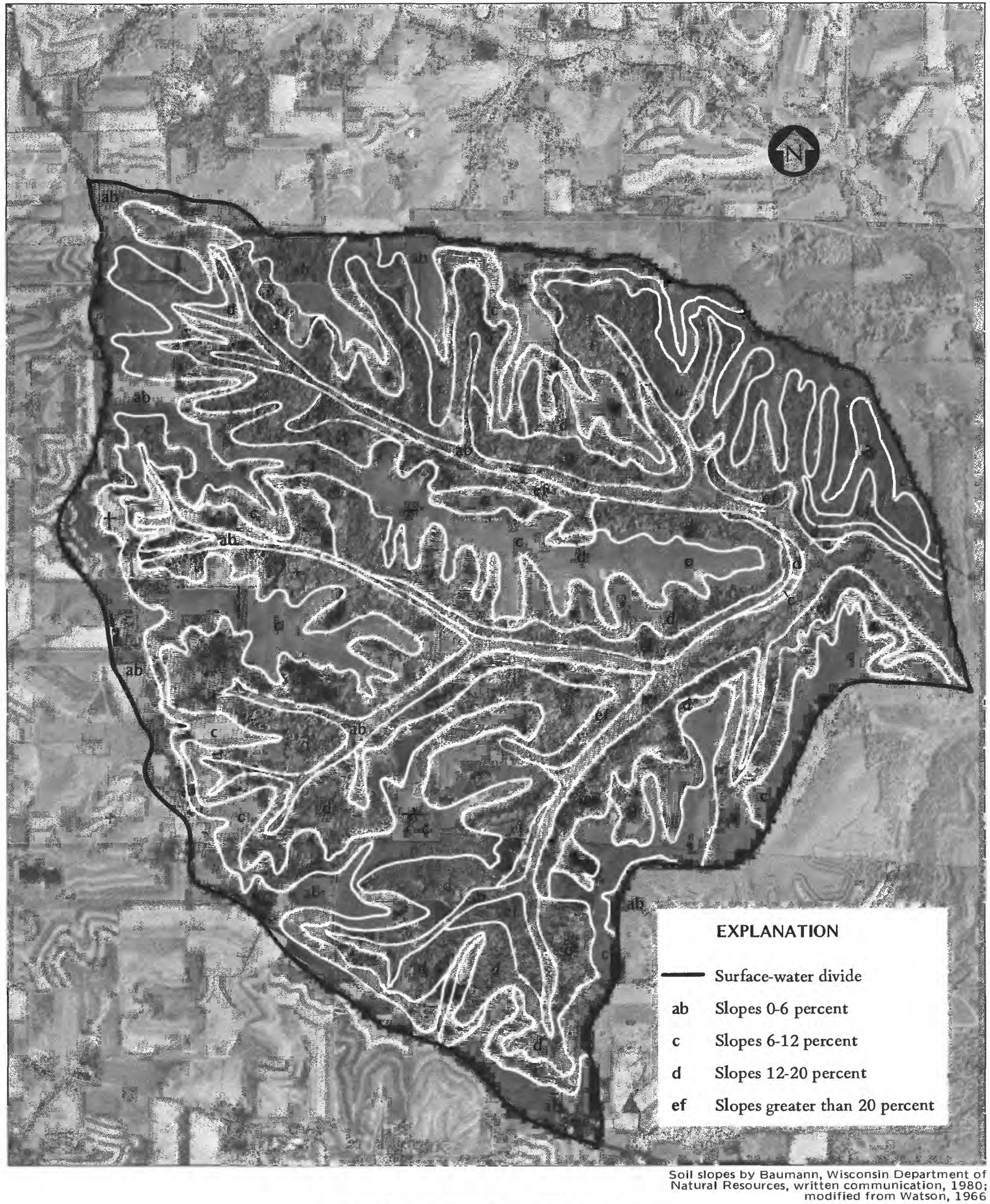

Figure 4. Soil slopes in Steiner Branch basin. 


\section{SAMPLING NETWORK AND DATA-COLLECTION METHODS}

A gaging station to monitor water discharge, temperature, and specific conductance, and an Isco Mode1 1680 automatic water sampler to collect samples during runoff for suspended sediments, nutrients, and other constituents was installed in October 1977 at Steiner Branch. In December 1977, the gaging station on the Yellowstone River was reactivated to monitor water discharge, and an Isco Mode1 1680 automatic water sampler to collect samples during runoff for suspended sediments was installed. A local observer was hired to collect suspended-sediment samples weekly during nonstorm periods.

In addition to the National Weather Service rain gages at Darlington, Blanchardville, and Dodgeville, precipitation records were also collected at the Yellowstone State Park from Apri1 1 to October 30, 1978, and April 1 to September 30, 1979.

For the nutrient samples, alternate, empty sample bottles were pretreated with $1 \mathrm{~mL}$ (milliliter) of mercuric chloride to inhibit bacterial or other biological activity and were removed from the sampler as soon as possible and chilled to $4^{\circ} \mathrm{C}$ by the Yellowstone State Park personnel. Generally, four samples pretreated with mercuric chloride and four untreated samples were selected throughout the hydrograph. Those treated with mercuric chloride were analyzed for total:

- Nitrite nitrogen

- Nitrite plus nitrate nitrogen

- Ammonia plus organic nitrogen
- Ammonia nitrogen

- Phosphorus

- Phosphorus, orthophosphate

The four untreated samples were filtered and analyzed for:

- Chloride

- Alkalinity

- Dissolved-solids, residue at $180^{\circ} \mathrm{C}$

Samples were selected from the remaining bottles for suspended-sediment analyses. All water-quality data were published in the U.S. Geological Survey's 1979 data report.

Several manually collected stream cross-section samples were collected concurrently with automatically collected samples covering a range of stream discharge. These samples were collected by the equa1-width increment method described by Guy and Norman (1970). The purpose of this was to insure that the automatically collected samples were representative of the average quality of water in the stream cross section.

At 6-week intervals, the following water-quality characteristics were determined :

$\cdot \mathrm{pH}$

- Dissolved oxygen

- Biochemical oxygen demand--5 day
- Fecal coliform bacteria

- Fecal streptococcus bacteria

- Chlorophy11 a and b 
$\mathrm{pH}$ and dissolved oxygen were determined at the gaging station with the Leeds and Northrup Model 7417 meter for $\mathrm{pH}$ and the Yellow Springs Instrument Co. Mode1 54 for dissolved oxygen. Samples for biochemical oxygen demand and fecal col1form and fecal streptococcus bacteria were chilled to $4^{\circ} \mathrm{C}$ and analyzed within 6 hours at the Survey's laboratory at Madison. Samples for chlorophyll a and b were chilled to $4^{\circ} \mathrm{C}$ and sent to the National Water Quality Laboratory at Doraville, Ga., for analyses.

\section{HYDROLOGIC CONDITIONS DURING STUDY PERIOD}

To evaluate the water-quality data collected, hydrologic conditions throughout the study period must first be assessed.

\section{Precipitation}

Precipitation values used in this report are from three National Weather Service stations at Dodgeville, Darlington, Blanchardville, and a station at Yellowstone State Park (fig. 1). The rain gage at Yellowstone State Park was read from April 1 to October 30, 1978, and April 1 to September 30, 1979. Precipitation amounts used throughout this report are the arithmetic means of the above stations except when explained in the text.

Precipitation totals for the 1978 water year were $38.65 \mathrm{in}$. and $32.43 \mathrm{in}$. for the 1979 water year.

Average annual precipitation at Dodgeville during a 57-year period was 33.04 in. (Environmental Data Service, 1973). Total precipitation and departure from normal for the 1977 to 1979 water years are shown in table 1. Both the 1977 and 1978 water years had greater than average precipitation, +6.32 in. and +5.04 in., respectively, whereas the 1979 water year had less than average, -4.01 in.

Table 1. Total precipitation and departure from normal, Dodgeville, Wis.

Total precipitation (in.)
Departure from normal (in.)
1977

1978

1979
39.36

38.58

29.03
$+6.32$

$+5.04$

$-4.01$

The 1978 water year had 10 storms that exceeded 1.0 in. of precipitation, including 6 greater than 1.5 in.; the 1979 water year had only 5 storms exceeding 1.0 in. of precipitation, including 2 greater than 1.5 in. 

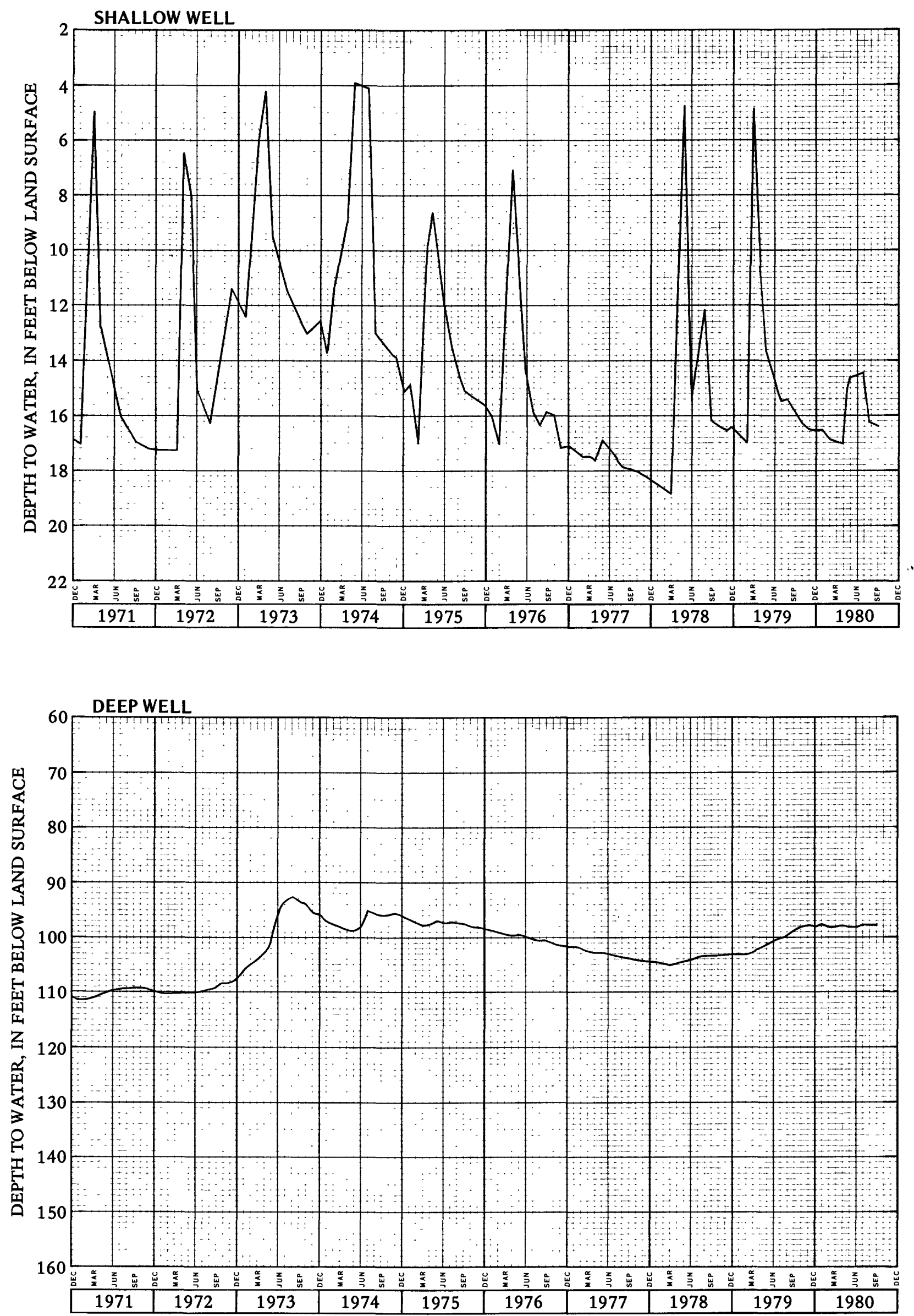

Figure 5. Water levels in a shallow and deep well. 
Moisture equivalents of the snowpack during the study period were significantly different for the 2 years. On March 4, 1978, just before snowmelt, molsture equivalent in the snowpack at Madison, $40 \mathrm{mi}$ to the northeast, was about $1.9 \mathrm{in}$. It is assumed that the snowpack in the Steiner Branch and Yellowstone River basins had similar moisture levels because from November to March precipitation at Dodgeville, Blanchardville, and Darlington was $5.43 \mathrm{in}$. compared with 5.27 in. at Madison. In contrast, on March 1, 1979, the moisture equivalent of the snowpack at Madison was 5.2 in.--a 50-year recurrence interval (U.S. Department of Commerce, 1964). Madison received 10.02 in. of precipitation from November to March, whereas at Blanchardville, Darlington, and Dodgeville, the average was $10.6 \mathrm{in}$.

\section{Ground-water levels̄s}

Despite above-average precipitation in 1977, at the beginning of the study, ground-water levels continued to decline until spring recharge in Apri1 1978. This is 1llustrated in figure 5 by two wells, a shallow well in St. Peter Sandstone of Middle Ordovician age and a deep well in the Galena-Platteville unit of Middle Ordovician age. The shallow well is near the basin (fig. 1), but the deep well (not shown on fig. 1) is about $25 \mathrm{mi}$ southwest of the basin. The shallow well reflects a relatively fast response to precipitation, whereas the deep well reflects the slower response in the deeper aquifer.

Snowmelt in March 1978 and significant precipitation during the rest of the 1978 water year reversed the declining trend of ground-water levels. By October 1978, the deep aquifer water levels had reached their highest point since the study began. They remained at this level until snowmelt in March 1979. When the high-moisture snowpack melted in March 1979, recharge of the ground-water reservoir was significant. Despite less than normal precipitation ( $4.75 \mathrm{in}$. at Dodgeville) for the remainder of the water year, deep aquifer water levels continued to rise. Generally, deep and shallow aquifer water levels were higher in 1979 than they were in 1978.

\section{Streamflow}

Summaries of the streamflow data collected for Steiner Branch and the Yellowstone River are shown in table 2, and hydrographs for Steiner Branch are shown in figures 6 and 7. Streamflow data for both stations are shown in tables 10 and 11 .

Total runoff for the Steiner Branch basin for the 1978 and 1979 water years was 1,500 and $1,800 \mathrm{ft}^{3} / \mathrm{s}-\mathrm{d}$ (cubic feet per second-days), respectively. Runoff from the Yellowstone River basin during the 1978 water year was 10 percent below the 13-year average; during the 1979 water year runoff was 20 percent above the 13-year average.

Stream discharge was greater in water year 1979 than 1978 even though precipitation was 4.01 in. less than normal in 1979 and 6.22 in. more than normal in 1978. Higher ground-water levels in 1979 than in 1978 caused greater base-flow runoff in 1979 than in 1978. Hydrograph separations shown in figures 6 and 7 indicate the base-flow runoff was about $900 \mathrm{ft}^{3} / \mathrm{s}-\mathrm{d}$ in $1978 \mathrm{com}-$ pared with $1,400 \mathrm{ft}^{3} / \mathrm{s}-\mathrm{d}$ in 1979. Direct runoff was about $400 \mathrm{ft}^{3} / \mathrm{s}-\mathrm{d}$ in 1979 

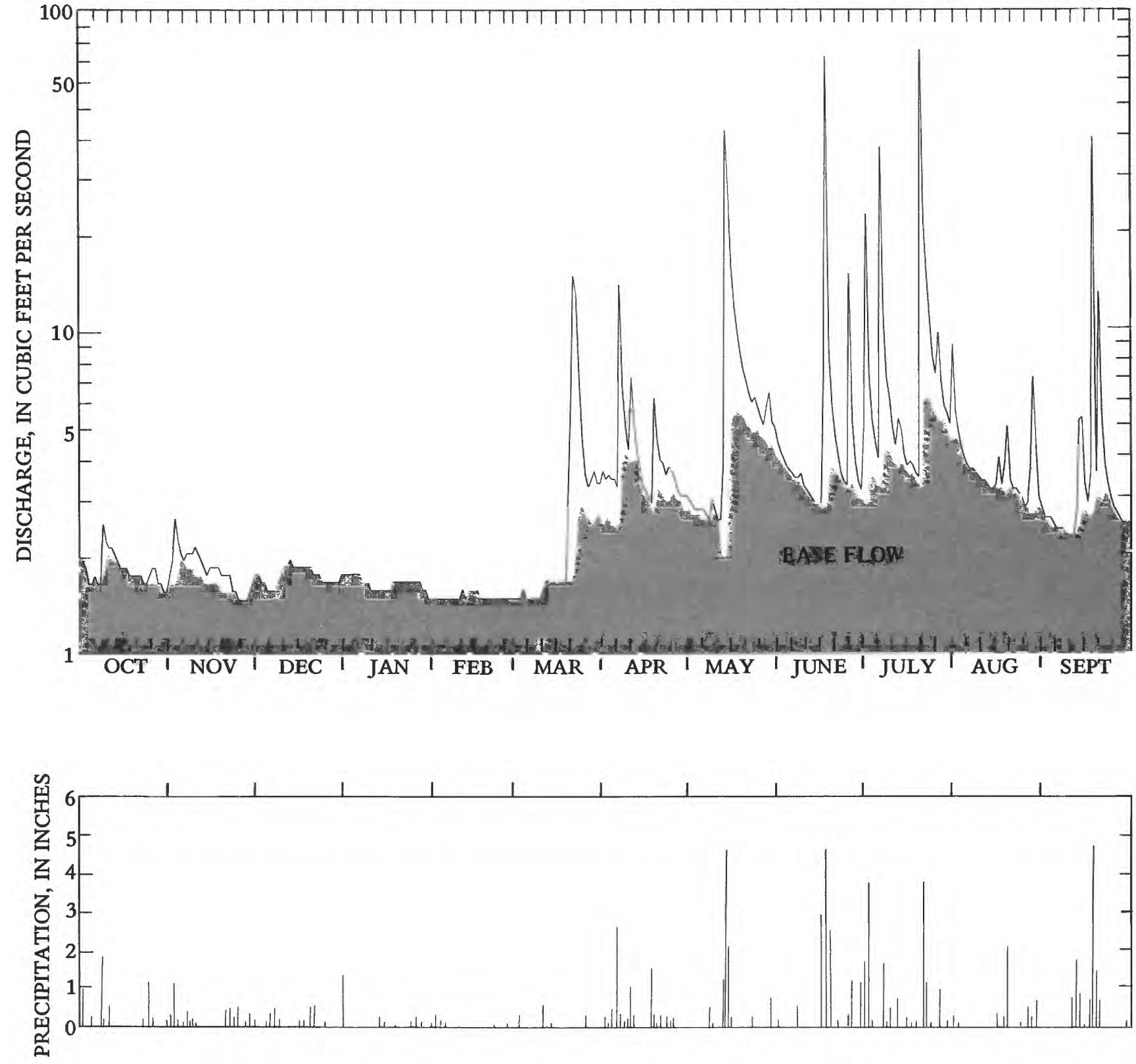

Figure 6. Hydrograph and precipitation for Steiner Branch, 1978 water year.

and $600 \mathrm{ft}^{3} / \mathrm{s}-\mathrm{d}$ in 1978. The greater direct runoff in 1978 than in 1979 was due to the greater than normal precipitation and numerous large storms in 1978. To illustrate this difference, the 1978 and 1979 hydrographs are superimposed in figure 8 .

Because hydrologic conditions are similar in the two river basins, the data from the Yellowstone River gaging station during the period of study comparing its long-term averages indicate the relative magnitude of the discharges at Steiner Branch. The storms during the 1978 water year caused stream discharge peaks of a much larger magnitude and more frequent occurrence than in 1979 (fig. 8). Instantaneous peak discharges above a base of $45 \mathrm{ft}^{3 / s}$ for Steiner 

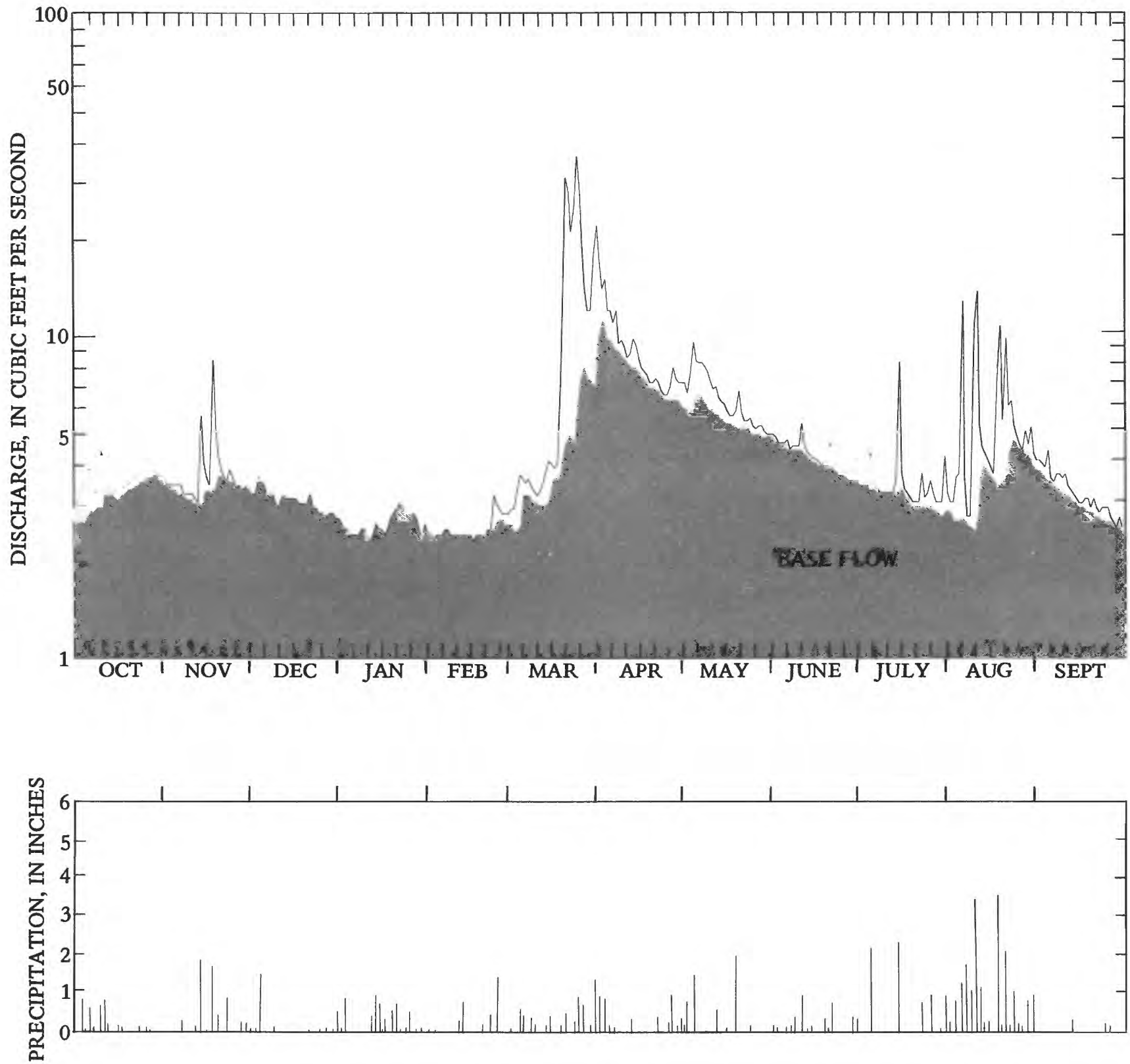

Figure 7. Hydrograph and precipitation for Steiner Branch, 1979 water year.

Branch are shown in table 3. For comparison, the peak discharges on the same day for Yellowstone River are also shown (table 3). The peak discharge of both streams was during the 1978 water year on July 20. The areal distribution of precipitation from that storm is shown in figure 9. About $3.2 \mathrm{in}$. of rain fell in the Steiner Branch basin, which caused a peak discharge of $392 \mathrm{ft} / \mathrm{s}$, while $2.74 \mathrm{In}$. of rain fell in the Yellowstone River basin, increasing the stream discharge to a peak of $1,850 \mathrm{ft}^{3} / \mathrm{s}$. This peak was at a recurrence interval equivalent to about a 5-year flood.

The minimum discharge at both streams was also during the 1978 water year on many days in February and March. Based on a low-flow frequency analysis of the recorded discharge at the Yellowstone River gage, the minimum discharge was 
Table 2. Summaries of discharge characteristics for Steiner Branch and Yellowstone River, 1978 and 1979 water years.

\begin{tabular}{|c|c|c|c|c|}
\hline \multirow{2}{*}{ Discharge parameter } & \multicolumn{2}{|c|}{ Steiner Branch } & \multirow{2}{*}{$\begin{array}{l}\text { Yellowstone } \\
1978\end{array}$} & \multirow{2}{*}{$\frac{\text { River }}{1979}$} \\
\hline & 1978 & 1979 & & \\
\hline $\begin{array}{l}\text { Discharge, in cubic feet per } \\
\text { second-days per year.......... }\end{array}$ & 1,500 & 1,802 & 5,262 & 7,039 \\
\hline $\begin{array}{l}\text { Mean discharge, in cubic feet } \\
\text { per second.................. }\end{array}$ & 4.12 & 4.94 & $\begin{array}{l}14.4 \\
1(16.0)\end{array}$ & $\begin{array}{l}19.3 \\
1(16.0)\end{array}$ \\
\hline $\begin{array}{l}\text { Discharge, in cubic feet per } \\
\text { second per square mile....... }\end{array}$ & .70 & .84 & .51 & .68 \\
\hline Inches of runoff........... & 9.49 & 11.36 & 6.87 & 9.19 \\
\hline $\begin{array}{l}\text { Minimum 7-day mean low-flow, } \\
\text { in cubic feet per second....... }\end{array}$ & 1.5 & 2.3 & 5.0 & 8.2 \\
\hline $\begin{array}{l}\text { Peak discharge, in cubic } \\
\text { feet per second.............. }\end{array}$ & 392 & 55 & 1,850 & 243 \\
\hline
\end{tabular}

${ }^{1}$ Average discharge, in cubic feet per second, for 13 years of record.

Table 3. Comparison of peak discharges of Steiner Branch and Yellowstone River.

\begin{tabular}{|c|c|c|c|c|c|c|}
\hline \multirow{2}{*}{\multicolumn{3}{|c|}{ Date }} & \multicolumn{2}{|c|}{ Steiner Branch } & \multicolumn{2}{|c|}{ Ye1lowstone River } \\
\hline & & & \multirow{2}{*}{ Time } & $\begin{array}{c}\text { Discharge } \\
\left(\mathrm{ft}^{3 / \mathrm{s}}\right)\end{array}$ & Time & $\begin{array}{c}\text { Discharge } \\
\left(\mathrm{ft}^{3} / \mathrm{s}\right)\end{array}$ \\
\hline May & 13, & 1978 & & 85 & 0930 & 155 \\
\hline June & 17 & 1978 & 1515 & 194 & 1415 & 1,290 \\
\hline July & 1 & 1978 & 1245 & 99 & 1245 & 221 \\
\hline July & 6 , & 1978 & 2145 & 186 & 2200 & 88 \\
\hline July & 20 & 1978 & 1715 & 392 & 1730 & 1,850 \\
\hline Sept. & 18 & 1978 & 0645 & 184 & 0545 & 498 \\
\hline Mar. & 23 & 1979 & 2145 & 48 & 2200 & 180 \\
\hline Aug. & 5 & 1979 & 1445 & 52 & 1345 & 143 \\
\hline Aug. & 9 & 1979 & 1015 & 55 & 0900 & 117 \\
\hline
\end{tabular}




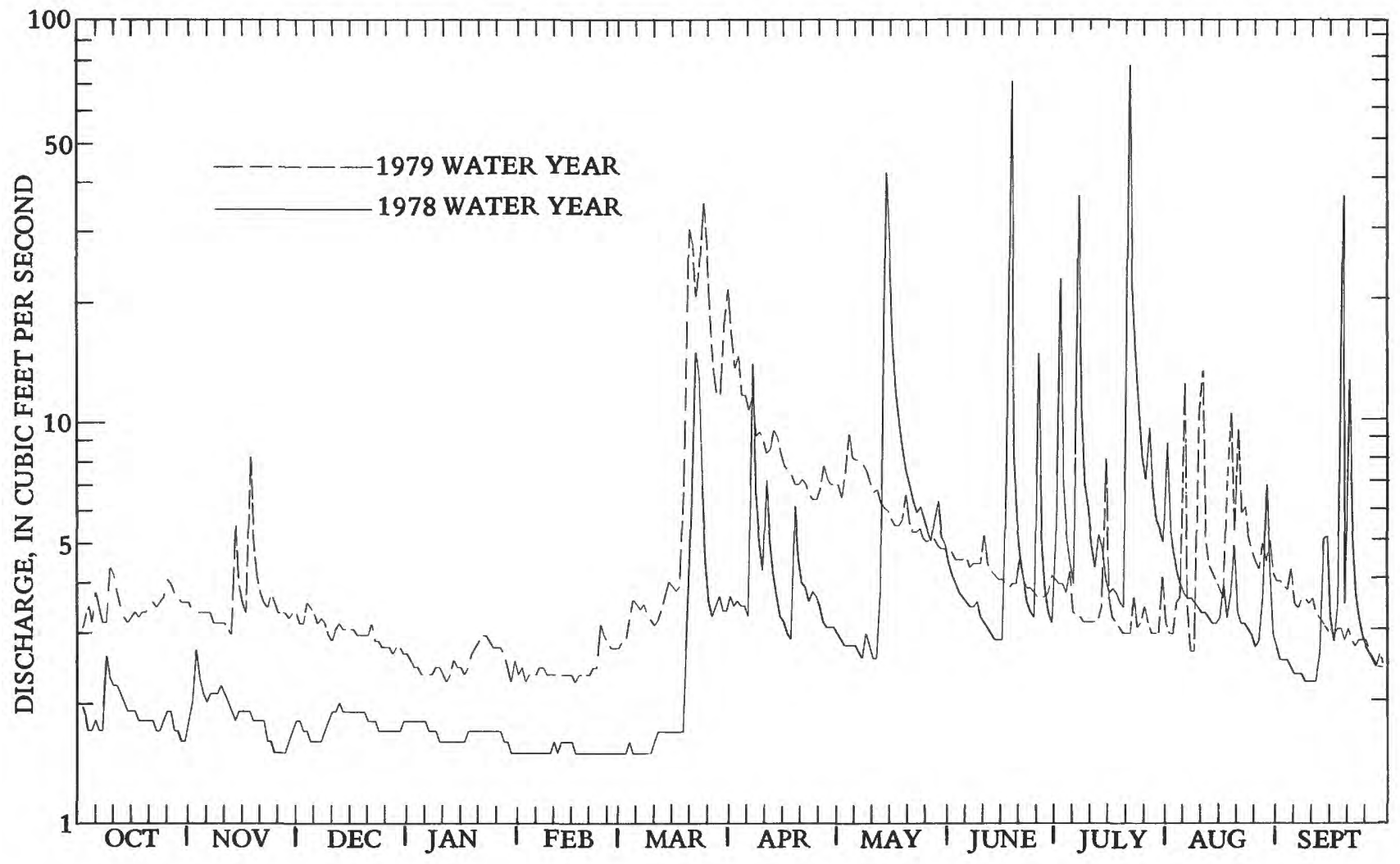

Figure 8. Hydrographs of the 1978 and 1979 water years for Steiner Branch.

slightly less than the average 7-day low flow that occurs on the average of once every 2 years.

\section{WATER QUALITY}

\section{Sediment}

In this study, only the suspended part of the total sediment load was measured and calculated. Bedload, that part of the total sediment load that moves on or near the streambed, was not measured. Hinda11 (1975) estimated bedload to be between 5 and 15 percent of the total load for the Yellowstone River. Bedload as a percentage of total load in Steiner Branch is probably similar to that of the Yellowstone River. Suspended-sediment loads were computed by streamflow and sediment-concentration integration techniques described by Porterfield (1972). A summary of suspended-sediment parameters for Steiner Branch and Yellowstone River is shown in table 4. Daily suspended-sediment loads for both stations are shown in tables 12 and 13.

Suspended-sediment yields for the Steiner Branch basin were 369 tons $/ \mathrm{mi}^{2}$ in the 1978 water year and 84.6 tons $/ \mathrm{mi}^{2}$ in 1979 . The average yleld was 


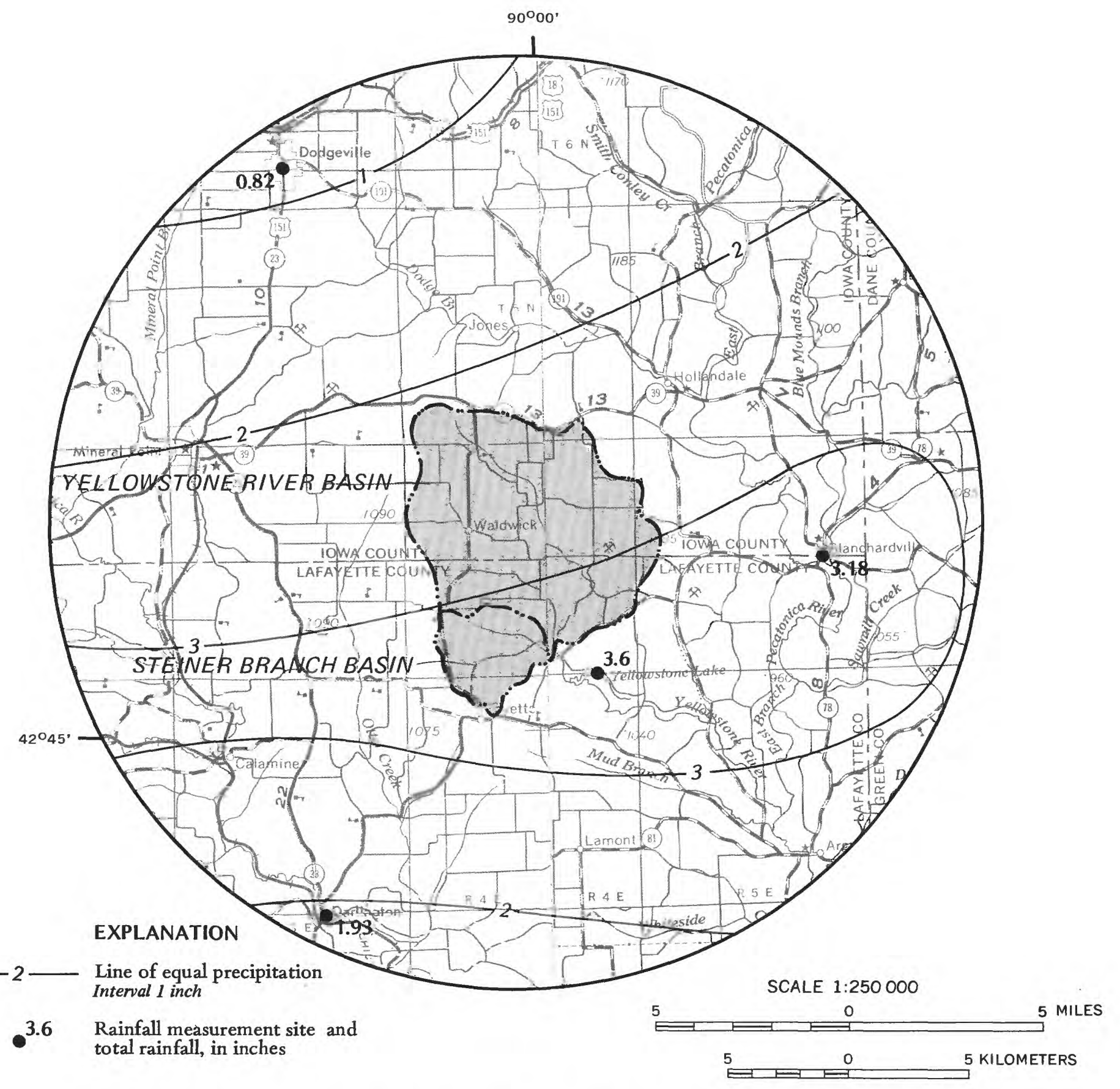

Figure 9. Precipitation for July 20, 1978 storm in the Steiner Branch and Yellowstone River basins.

227 tons $/ \mathrm{mi}^{2}$ for the 2-year study. These yields are 1.66 times greater than those in the Yellowstone River basin. The 8-year average (1955-60 and 1978-79) yield for the Yellowstone River basin is 268 tons/mi ${ }^{2}$. The estimated long-term average yield for Steiner Branch is 444 tons $/ \mathrm{mi}^{2}$ and was determined as follows:

\begin{tabular}{|c|c|c|c|c|c|c|}
\hline \multirow{2}{*}{$\begin{array}{l}\text { long-term } \\
\text { Steiner Branch } \\
\text { basin yleld }\end{array}$} & \multirow{2}{*}{$=$} & 268 tons $/ \mathrm{mi}^{2}$ & $\begin{array}{l}\text { (1ong-ter } \\
\text { River }\end{array}$ & $\begin{array}{l}\text { rm Yellowstone } \\
\text { basin yield) }\end{array}$ & \multirow{2}{*}{$\mathrm{X}$} & \multirow{2}{*}{$\begin{array}{l}227 \text { tons } / \mathrm{mi}^{2} \text { ( } 1978-79 \\
\text { Steiner Branch basin } \\
\text { yield) }\end{array}$} \\
\hline & & 137 tons $/ \mathrm{mi}^{2}$ & $\begin{array}{r}\text { (1978-79 } \\
\text { River }\end{array}$ & $\begin{array}{l}\text { Yellowstone } \\
\text { basin yield) }\end{array}$ & & \\
\hline
\end{tabular}




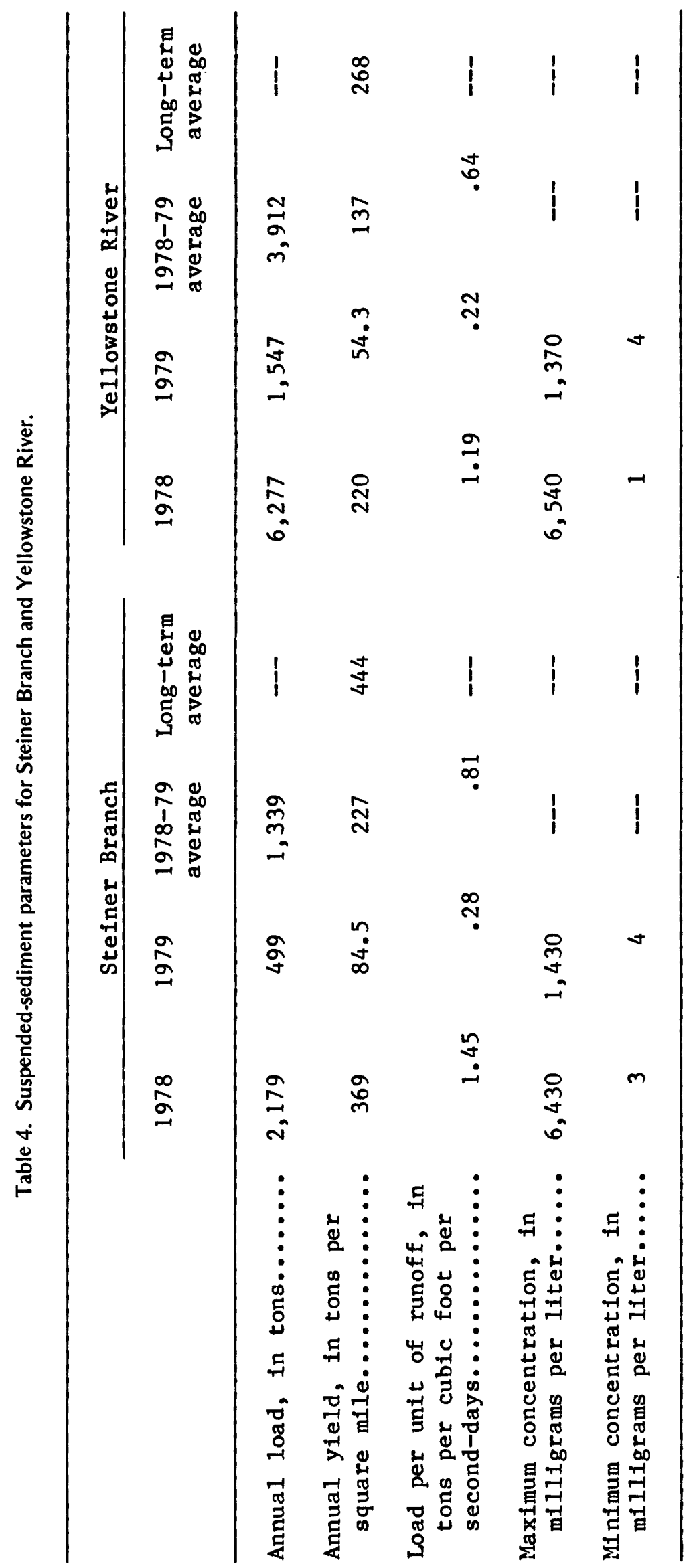


Suspended-sediment load per unit of runoff is another method for comparing the two basins. The sediment load per unit of runoff in the Steiner Branch basin is 0.81 ton $/ \mathrm{ft}^{3}$ per second-day, whereas in the Yellowstone River basin it is 0.64 ton $/ \mathrm{ft}^{3}$ per second-day for the 2-year study. Sediment load per unit of runoff is 1.30 times higher in the Steiner Branch basin than in the Yellowstone River basin.

Suspended-sediment discharge is closely associated with direct runoff. As previously discussed, the more frequent and larger storms in 1978 than in 1979 produced greater direct runoff in 1978 than in 1979. Consequently, sediment loads of both streams were greater in 1978 than in 1979. During the study period 90 percent of the suspended-sediment load in Steiner Branch was transported during periods of direct runoff. Sediment loads for days above a base of 25 tons are given in table 5 .

Table 5. Daily suspended-sediment loads for days when the load was more than $\mathbf{2 5}$ tons at Steiner Branch, 1978 and 1979 water years.

\begin{tabular}{cccc}
\hline & $\begin{array}{c}\text { Daily } \\
\text { Duspended- } \\
\text { sediment load } \\
\text { (tons) }\end{array}$ & Date & $\begin{array}{c}\text { Daily } \\
\text { suspended- } \\
\text { sediment 1oad } \\
\text { (tons) }\end{array}$ \\
\hline Mar. 21, 1978 & 32 & July 20, 1978 & 505 \\
May 13, 1978 & 185 & Mar. 19, 1979 & 68 \\
June 16, 1978 & 33 & Mar. 20, 1979 & 25 \\
June 17, 1978 & 643 & Mar. 23, 1979 & 43 \\
June 25, 1978 & 117 & Aug. 5, 1979 & 28 \\
July 1, 1978 & 133 & Aug. 10, 1979 & 35 \\
July 6, 1978 & 187 & & \\
\hline
\end{tabular}

Particle-size distribution of the suspended sediments on March 21, 1978, for Steiner Branch was 34 percent clay $(0.00024$ to $0.004 \mathrm{~mm}), 64$ percent silt $(0.004$ to $0.062 \mathrm{~mm})$, and 2 percent sand $(0.062$ to $2.0 \mathrm{~mm}$ ) and are identical to the sample taken on the same date on the Yellowstone River. Figure 10 is a plot of the particle-size analysis for the Yellowstone River of March 21, 1978, and previous analyses. It shows the March 21, 1978, analysis is representative of the sand fraction, but, for the period of record, clay tends to be more in the 65 to 75 percent range, whereas silt is more in the 20 to 30 percent range. This may also be true of the Steiner Branch basin. 


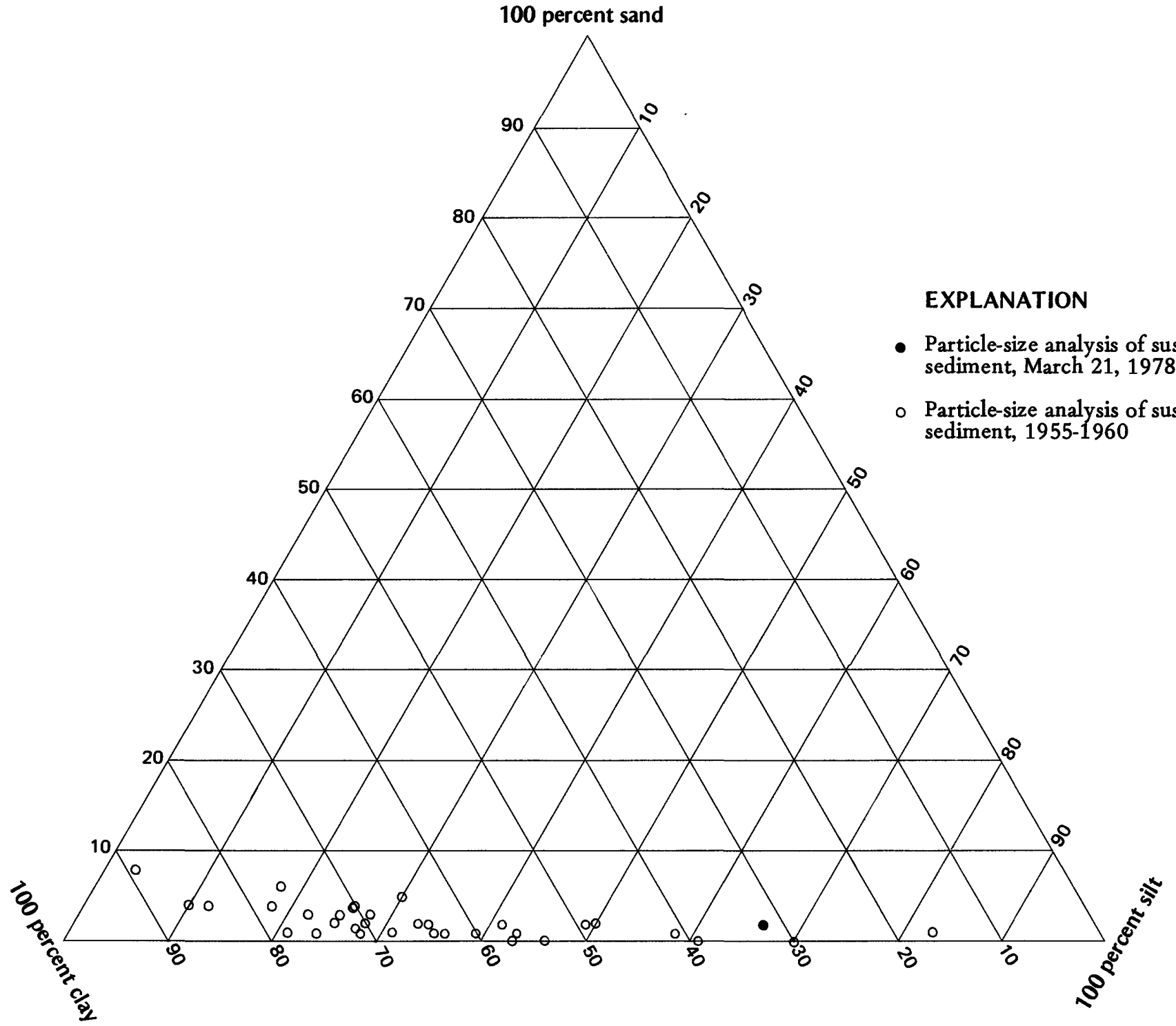

Figure 10. Particle-size distribution of suspended sediment at Yellowstone River.

At Steiner Branch, peak sediment concentrations for most storms generally preceded the peak stream discharge; however, there is a slight tendency toward coincident concentration and stream discharge peaks. The maximum sediment concentration of $6,430 \mathrm{mg} / \mathrm{L}$ and the maximum daily sediment load of 643 tons occurred on June 17, 1978. A plot of the sediment concentration and stream discharge versus time for two large storms (June 16-17 and July 20-21, 1978) are shown in figure 11. The July 20 storm exhibited a sediment-concentration pattern characteristic of large storms in the basin. After the peak, as the stream discharge and sediment concentration decreased, the sediment concentration gradually reversed its declining trend and started to increase. This was most likely due to a resuspension of sediment as the ponded flood water drained from the flood plain. 


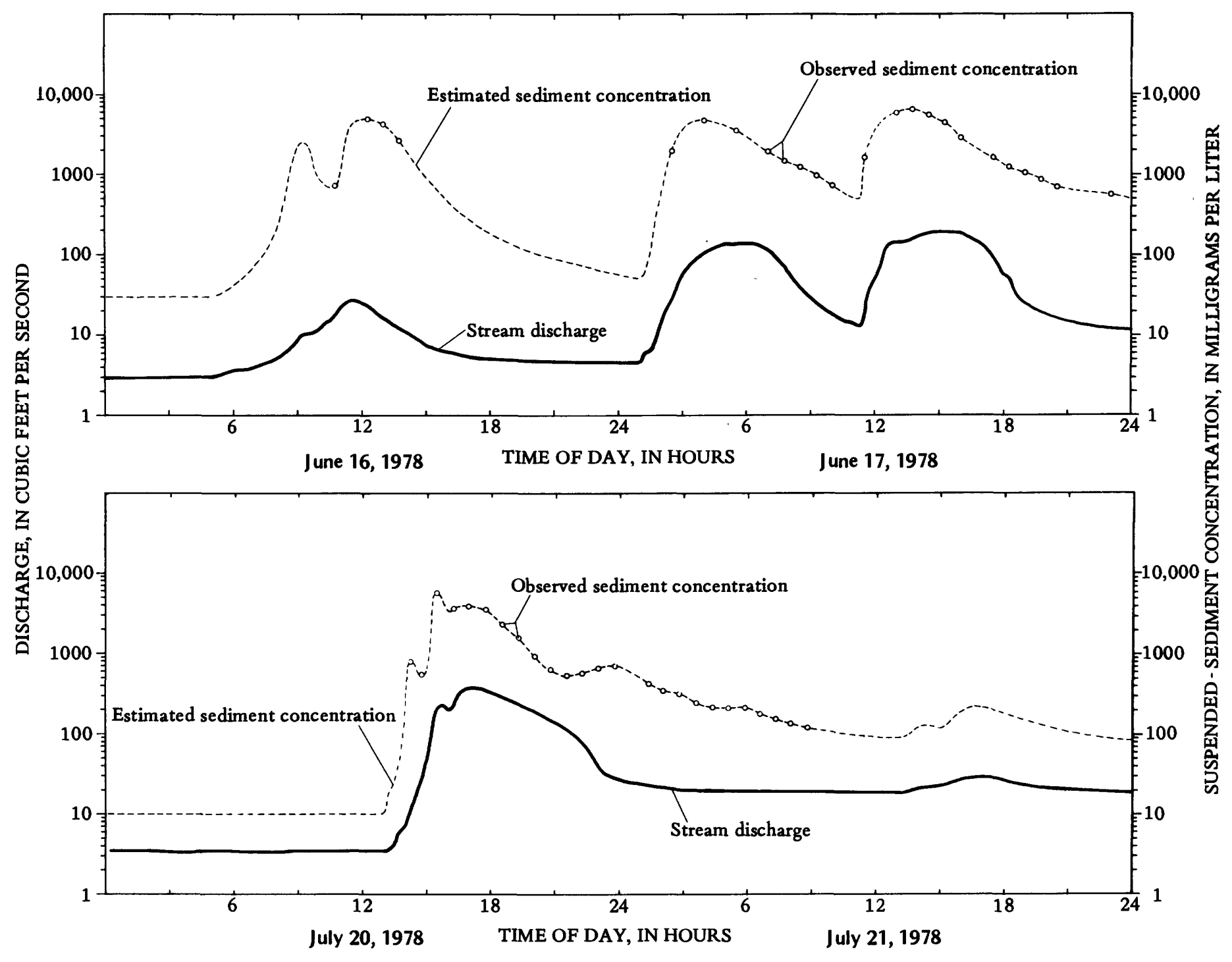

Figure 11. Stream discharge and suspended-sediment concentration for storms of June 16-17 and July 20-21, 1978.

The minimum sediment concentration of $3 \mathrm{mg} / \mathrm{L}$ on Steiner Branch and the minimum daily sediment load of 0.01 ton occurred on February 28, 1978.

Annual suspended-sediment yields for the Yellowstone River basin for both study years were less than the 8-year average (table 6). The yield in the 1978 water year was 220 tons $/ \mathrm{mi}^{2}$, and in 1979 it was 54.3 tons $/ \mathrm{mi}^{2}$. The maximum daily sediment load of 2,790 tons on June 17, 1978, was less than the maximum daily sediment load of 7,500 tons that occurred in 1960. The 1979 water year, however, had the lowest maximum daily sediment load in the 8 years of record. 


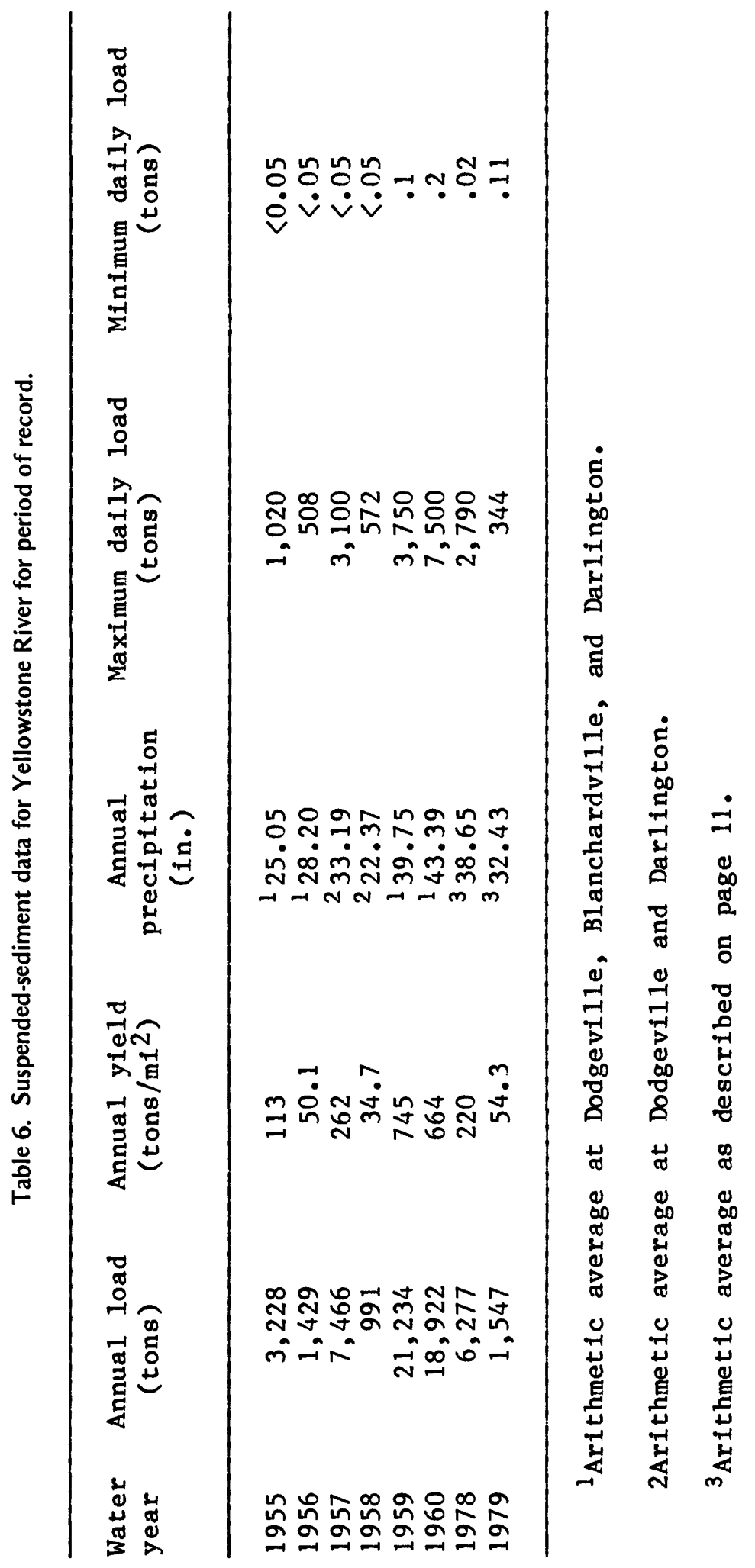


The maximum observed sediment concentration for the period of study was $6,450 \mathrm{mg} / \mathrm{L}$ on June 17, 1978; it was, however, considerably less than the maximum observed sediment concentration of $9,040 \mathrm{mg} / \mathrm{L}$ (Hinda11, 1975). Minimum sediment concentration and minimum dally sediment loads were similar to those of past years. Considering the above data, the yields from the Steiner Branch basin for the 2-year study period are probably also lower than average.

\section{General water quality}

The water in Steiner Branch is of the calcium magnesium bicarbonate type with these being the dominant cations and anion, respectively. The water is slightly alkaline ( $\mathrm{pH}$ range $7.8-8.4$ ), with alkalinity ranging from 40 to $300 \mathrm{mg} / \mathrm{L}$ as calcium carbonate. These values are typical of those in southern Wisconsin streams. Relative1y low biochemical oxygen demand (BOD) $(0.8-3.4 \mathrm{mg} / \mathrm{L})$ and periphyton biomass chlorophy11 ratios $(30-200)$, known as the autotrophic index (AI), indicate a low leve1 of organic loading to the stream. The autotrophic index is computed by dividing the ash-free dry weight $\left(\mathrm{g} / \mathrm{m}^{2}\right)$ of the periphyton sample by the chlorophy11 a content $\left(\mathrm{g} / \mathrm{m}^{2}\right)$. Values above 100 are genera11y considered to indicate some organic pollution (Weber, 1973). For heavily organica11y enriched streams, values are generally in the thousands.

Fecal coliform and fecal streptococcus bacteria were analyzed throughout the study. These bacteria indicate fecal contamination and the possible presence of pathogenic organisms. The values for fecal coliform bacteria ranged from 1 to 1,500 colonies per $100 \mathrm{~mL}$ of sample, with a median of 49; those for fecal streptococcus bacteria ranged from 10 to 63,000 colonies per $100 \mathrm{~mL}$, with a median of 240.

The ratio of fecal coliform to fecal streptococcus bacteria can be helpful in determining the source of fecal pollution in streams. Based on this ratio, the source of the slight organic contamination of Steiner Branch was domestic animals and wildlife, not from human wastes.

Constituent concentrations reported for whole water samples represent more than 95 percent of the total concentration of the constituents in the water and sediment mixture. Whole water samples for pesticide analyses were collected from Steiner Branch during both water years. Except for a concentration of $23 \mu \mathrm{g} / \mathrm{L}$ of atrazine found in a sample collected March 21, 1978, the concentrations of pesticides were less than the detection limit. No data are available concerning recommended levels of atrazine in waters, but bioassays of a variety of fish and invertebrates found no adverse effects at levels of $1 \mathrm{mg} / \mathrm{L}$ (Batte11, 1971).

The levels of trace metals in Steiner Branch fall below the estab1ished acceptable drinking-water standards (U.S. Environmenta1 Protection Agency, 1976; National Academy of Sciences and National Academy of Engineering, 1972) except for iron, mercury, and lead. The criterion for iron for protection of freshwater aquatic life is $1.0 \mathrm{mg} / \mathrm{L}$. The value for total recoverable iron in Steiner Branch was $2.0 \mathrm{mg} / \mathrm{L}$. The results from a "total recoverable" analysis are commonly less than the results from a "total" analysis, on which the water-quality criteria are based. Therefore, the reported trace metal values may be conservative. The value for mercury $(4.2 \mu \mathrm{g} / \mathrm{L})$ exceeds the recommended criterion of 
for lead, $0.049 \mathrm{mg} / \mathrm{L}$, for which the recommended limit to protect aquatic life is $0.03 \mathrm{mg} / \mathrm{L}$.

\section{Base-flow quality}

Base-flow samples were collected at various times on Steiner Branch. Seasonal trends are not apparent from the data.

The average nutrient yields, in pounds per square mile of drainage area per day, during base-flow periods are shown in table 7 . The values shown are for whole water samples (unfiltered), although, during base-flow periods, the greater amount of constituent may be in the dissolved phase due to the small amount of suspended material in the water column.

Nitrite nitrogen was almost nonexistent in the base-flow water samples. This is expected due to the relatively rapid rate of oxidation of nitrite ( $\left.\mathrm{NO}_{2-}\right)$ to nitrate $\left(\mathrm{NO}_{3}-\right)$ under well-aerated conditions usually present during base-flow periods. Nitrate nitrogen, however, accounted for 87 percent of the total nitrogen present. Organic nitrogen accounted for about 11 percent and ammonia nitrogen, 1 percent. Thirty-four percent of the total phosphorus was phosphorus, orthophosphate.

Arithmetic averages of constituent concentrations are as useful as flowvolume averages in streams. Arithmetic averages provide information concerning instream conditions at the time of sampling; flow-weighted volume averages provide information about the net water exported from a basin during a given time interva1. Constituent concentration data, such as sediment, phosphorus, or nitrogen concentrations, are also the basis for the establishment of water-quality criteria and standards as well as the basis for management recommendations. Table 7 indicates average concentrations for base-flow sample constituents.

EPA (U.S. EPA, 1976) has suggested that to prevent the formation of biological nuisance growths, the following concentrations of total phosphorus should not be exceeded:

- $0.1 \mathrm{mg} / \mathrm{L}$ for streams not discharging into lakes or impoundments,

- $0.05 \mathrm{mg} / \mathrm{L}$ in any stream at the point where it enters a lake or reservoir, and

- $0.025 \mathrm{mg} / \mathrm{L}$ within a lake or reservoir.

The range of values for total phosphorus collected on Steiner Branch during low-flow periods was $0.02-0.06 \mathrm{mg} / \mathrm{L}$, with the exception of one sample which had $0.23 \mathrm{mg} / \mathrm{L}$. The median value was $0.05 \mathrm{mg} / \mathrm{L}$.

The relative contribution of base flow to total yields for the period of study for the various constituents is shown in table 7.

Data collected by the Wisconsin Department of Natural Resources at about the same location on Steiner Branch during 1974-75 agree with base-flow analysis results obtained during this study. 


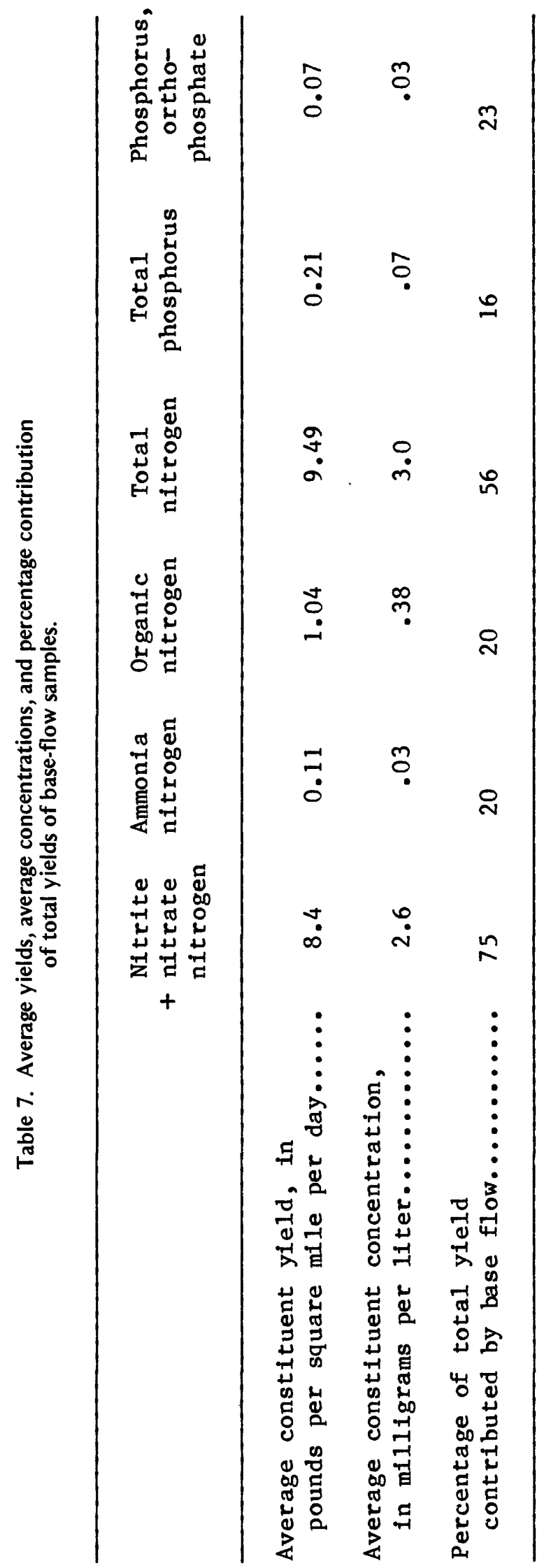


Water quality for selected storms

Eight storms during the 1978 water year and six storms during the 1979 water year were sampled on Steiner Branch for selected chemical constituents. All constituents were analyzed in whole water samples.

The loads for the individual 14 runoff events that were sampled for various constituents are shown in table 8 . The variations in constituent and suspendedsediment concentrations are illustrated in the hydrograph of the storm of July 20-21, 1978 (fig. 12). These patterns are typical of most of the storms sampled. As 1llustrated, total phosphorus, orthophosphorus, total nitrogen, organic nitrogen, and ammonia nitrogen concentrations all closely follow concentrations of suspended sediment; nitrate plus nitrite nitrogen demonstrates an inverse relationship to stream discharge. Higher base flows caused by snowmelt or precipitation, however, contain higher concentrations of nitrate.

Note that, for the Ju1y 20-21, 1978, storm, the concentrations of total phosphorus, total nitrogen, organic nitrogen, and ammonia nitrogen peak before the stream discharge peak. This is unique to this storm in this study but has been shown to be common in other studies (Ward and Eckhardt, 1979; Sharpley and others, 1976). As was the case for sediment concentrations, increases in the concentrations of total nitrogen, organic nitrogen, and probably total phosphorus and ammonia nitrogen late in the storm were most likely due to a resuspension of sediment from the flood plain as the ponded floodwaters drained back to the channel.

About 84 percent of the total phosphorus transport during the study occurred during runoff. Phosphorus yields are closely related to suspendedsediment yields and stream discharge in the Steiner Branch basin, as they have been demonstrated to be in other basins (McElroy and others, 1976; Verhoff and others, 1979; Cah111, 1977; Sharpley and others, 1976). This is a direct result of the transport mechanisms involved in delivering phosphorus to the stream. Phosphorus is quickly adsorbed to the surface of soil particles, demonstrating a preference for the silt and clay fraction. These small particles have a greater surface area-to-welght ratio than larger diameter particles and thus are more efficient transporters of phosphorus. When soil is eroded during a rain storm, the sorbed phosphorus is transported to the stream along with soll particles.

Figure 13 indicates the proportion of total phosphorus that was orthophosphorus for the runoff events sampled. The total phosphorus in streams is composed of inorganic and organic phosphorus. Inorganic phosphorus is composed primarily of orthophosphorus (the equivalent of orthophosphate). The dissolved part and, eventually, part of the suspended orthophosphate is available to plants as a major nutrient for growth.

Nitrite plus nitrate nitrogen was the largest component of the total nitrogen transported, although organic nitrogen was the dominant part of the total transported nitrogen during most of the runoff events (an average of 58 percent of total nitrogen). Figure 14 indicates the constituent proportions of total nitrogen for the sampled runoff events. About 80 percent of the organic nitrogen fraction during the study period was transported during runoff, indicating that the transport mechanisms for organic nitrogen may be similar to those for 
Table 8. Constituent loads and percentage of

[The numbers in this table have been rounded to three significant figures from the computer-generated tables]

\begin{tabular}{|c|c|c|c|c|c|c|}
\hline \multirow{2}{*}{ Dates } & \multicolumn{2}{|c|}{ Total nitrogen } & \multicolumn{2}{|c|}{$\begin{array}{l}\text { Nitrite + nitrate } \\
\text { nitrogen }\end{array}$} & \multicolumn{2}{|c|}{ Organic nitrogen } \\
\hline & $\begin{array}{l}\text { Load } \\
\text { (1b) }\end{array}$ & $\begin{array}{l}\text { Percent of } \\
\text { total yield }\end{array}$ & $\begin{array}{l}\text { Load } \\
\text { (1b) }\end{array}$ & $\begin{array}{l}\text { Percent of } \\
\text { total yield }\end{array}$ & $\begin{array}{l}\text { Load } \\
\text { (1b) }\end{array}$ & $\begin{array}{l}\text { Percent of } \\
\text { total yield }\end{array}$ \\
\hline Mar. 18-23, 1978 & 1,270 & 1.7 & 525 & 1.1 & 625 & 2.8 \\
\hline Apr. 5-7, 1978 & 472 & $<1$ & 270 & $<1$ & 170 & $<1$ \\
\hline May $12-15,1978$ & 3,940 & 5.3 & 1,350 & 2.8 & 2,250 & 10.2 \\
\hline June $16-19,1978$ & 6,640 & 8.9 & 950 & 2.0 & 5,280 & 23.9 \\
\hline $\begin{array}{l}\text { June } 30- \\
\text { Ju1y } 2,1978\end{array}$ & 1,350 & 1.8 & 313 & $<1$ & 963 & 4.4 \\
\hline Ju1y 6-8, 1978 & 2,230 & 3.0 & 446 & $<1$ & 1,710 & 7.7 \\
\hline July $19-22,1978$ & 2,500 & 3.3 & 675 & 1.4 & 1,560 & 7.1 \\
\hline Sept. $17-21,1978$ & 1,520 & 2.0 & 490 & 1.0 & 866 & 3.9 \\
\hline Nov. $17-18,1978$ & 256 & $<1$ & 161 & $<1$ & 82 & $<1$ \\
\hline Mar. $18-31,1979$ & 9,830 & 13.2 & 6,100 & 12.6 & 2,240 & 10.1 \\
\hline Ju1y $14-15,1979$ & 312 & $<1$ & 141 & $<1$ & 152 & $<1$ \\
\hline Aug. 5-8, 1979 & 689 & $<1$ & 269 & $<1$ & 399 & 1.8 \\
\hline Aug. 9-11, 1979 & 822 & 1.1 & 412 & $<1$ & 341 & 1.5 \\
\hline Aug. 17-21, 1979 & 1,070 & 1.4 & 488 & 1.0 & 493 & 2.2 \\
\hline
\end{tabular}


total yields for the 14 runoff events sampled.

\begin{tabular}{|c|c|c|c|c|c|c|c|}
\hline \multicolumn{2}{|c|}{ Ammonia nitrogen } & \multicolumn{2}{|c|}{ Total phosphorus } & \multicolumn{2}{|c|}{$\begin{array}{l}\text { Phosphorus, } \\
\text { orthophosphate }\end{array}$} & \multicolumn{2}{|c|}{ Suspended sediment } \\
\hline $\begin{array}{l}\text { Load } \\
\text { (1b) }\end{array}$ & $\begin{array}{l}\text { Percent of } \\
\text { total yield }\end{array}$ & $\begin{array}{l}\text { Load } \\
\text { (1b) }\end{array}$ & $\begin{array}{l}\text { Percent of } \\
\text { total yleld }\end{array}$ & $\begin{array}{l}\text { Load } \\
(1 \mathrm{~b})\end{array}$ & $\begin{array}{l}\text { Percent of } \\
\text { total yleld }\end{array}$ & $\begin{array}{l}\text { Load } \\
\text { (ton) }\end{array}$ & $\begin{array}{l}\text { Percent of } \\
\text { total yield }\end{array}$ \\
\hline 102 & 4.3 & 113 & 2.0 & 48 & 3.6 & 50.9 & 2.1 \\
\hline 29 & 1.2 & 28 & $<1$ & 15 & 1.1 & 10.3 & .4 \\
\hline 322 & 13.6 & 488 & 8.8 & 97 & 7.3 & 88.9 & 3.7 \\
\hline 315 & 13.3 & 1,030 & 18.6 & 225 & 16.8 & 682 & 28.3 \\
\hline 51 & 2.2 & 211 & 3.8 & 29 & 2.2 & 138 & 5.7 \\
\hline 56 & 2.4 & 310 & 5.6 & 55 & 4.1 & 196 & 8.2 \\
\hline 202 & 8.5 & 1,340 & 24.3 & 187 & 14.0 & 517 & 21.5 \\
\hline 105 & 4.4 & 234 & 4.2 & 49 & 3.7 & 74.8 & 3.1 \\
\hline 11 & $<1$ & 15 & $<1$ & 6 & $<1$ & 4.91 & .2 \\
\hline 514 & 21.7 & 510 & 9.2 & 166 & 12.4 & 236 & 9.8 \\
\hline 17 & $<1$ & 25 & $<1$ & 6 & $<1$ & 11.9 & .5 \\
\hline 32 & 1.4 & 90 & 1.6 & 22 & 1.6 & 29.1 & 1.1 \\
\hline 50 & 2.1 & 100 & 1.8 & 49 & 3.7 & 47.0 & 2.0 \\
\hline 49 & 2.1 & 130 & 2.3 & 58 & 4.3 & 14.5 & .6 \\
\hline
\end{tabular}




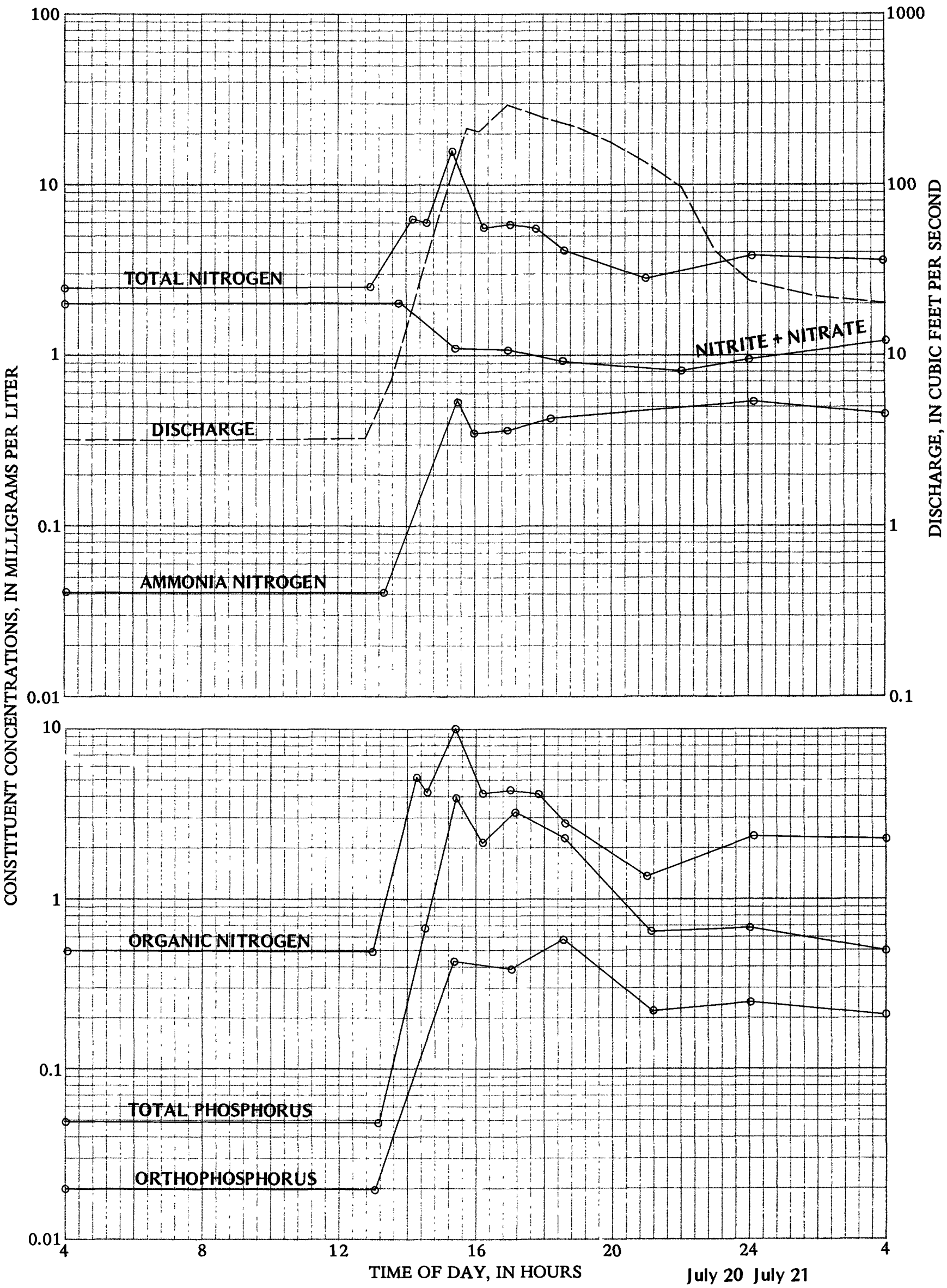

Figure 12. Hydrograph and constituent concentration graphs of the July 20-21, 1978 storm for Steiner Branch. 


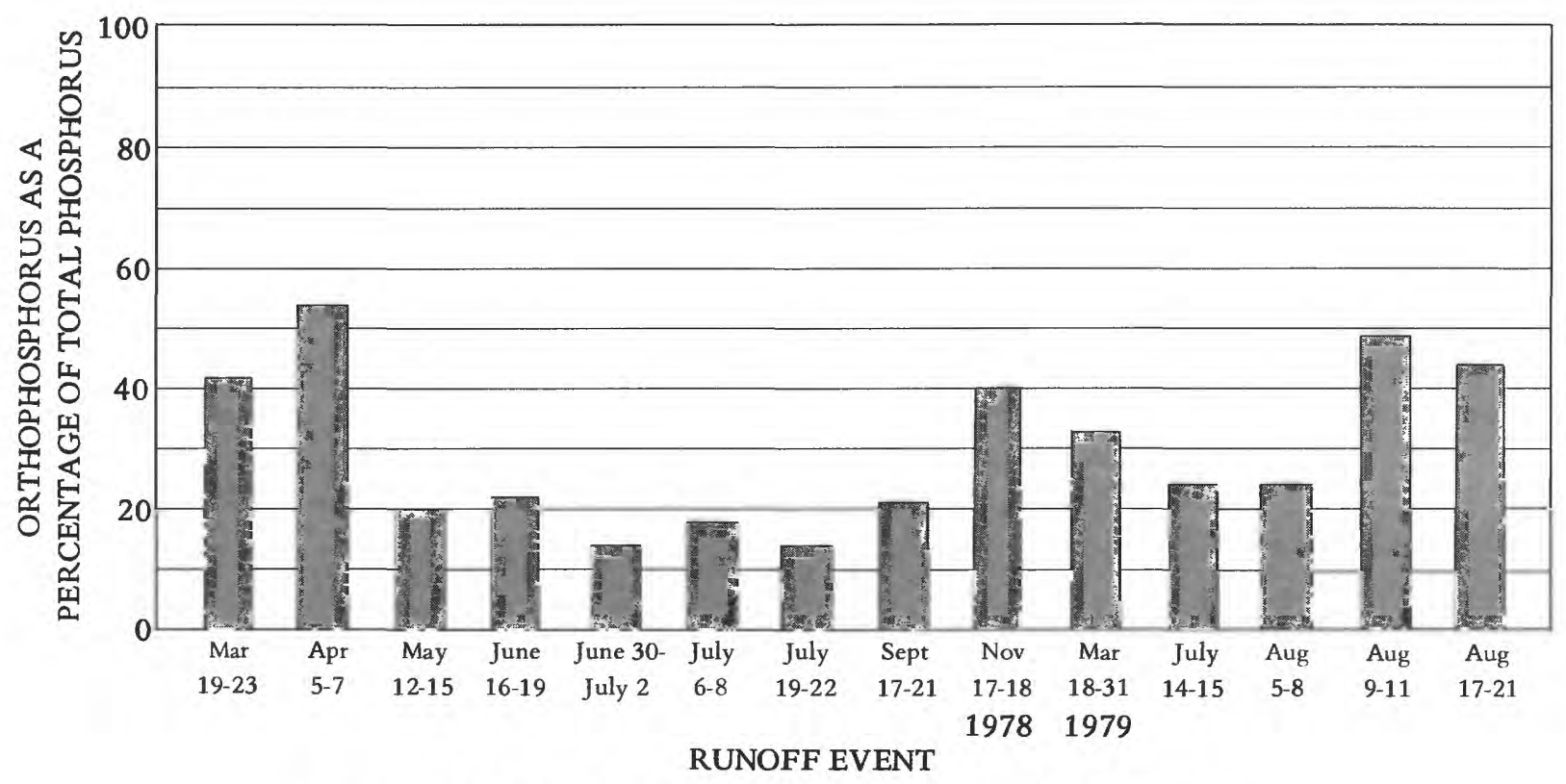

Figure 13. Orthophosphorus as a percentage of total phosphorus.

phosphorus. Ammonia nitrogen demonstrated the same pattern. An average of 7 percent of the total nitrogen in the sampled runoff events was ammonia nitrogen. About 80 percent of the ammonia nitrogen fraction was transported during runoff. The positively charged ammonium ions have an affinity for the negatively charged surfaces of clay-size soil particles and thus are transported in a "piggy-back" fashion during runoff along with the suspended sediments.

Figure 15 contains graphs of lines described by bivariate regression equations demonstrating the relationships between suspended-sediment concentration and constituent concentrations in Steiner Branch. These relationships are generally well defined, showing strong positive correlations of the nutrient constituent concentrations with sediment concentrations.

Nitrite and nitrate nitrogen are, however, readily soluble forms of nitrogen. They can leach through the soil profile along with precipitation, percolate to the ground-water reservoir, and eventually discharge to a surface-water body. Therefore, it is expected that the major part of the nitrite plus nitrate nitrogen would be contributed from base flow. The data collected on Steiner Branch showed that 75 percent of the nitrite plus nitrate nitrogen load was associated with base flow. 


\section{EXPLANATION}

Ammonia nitrogen

Nitrite + Nitrate nitrogen

Organic nitrogen

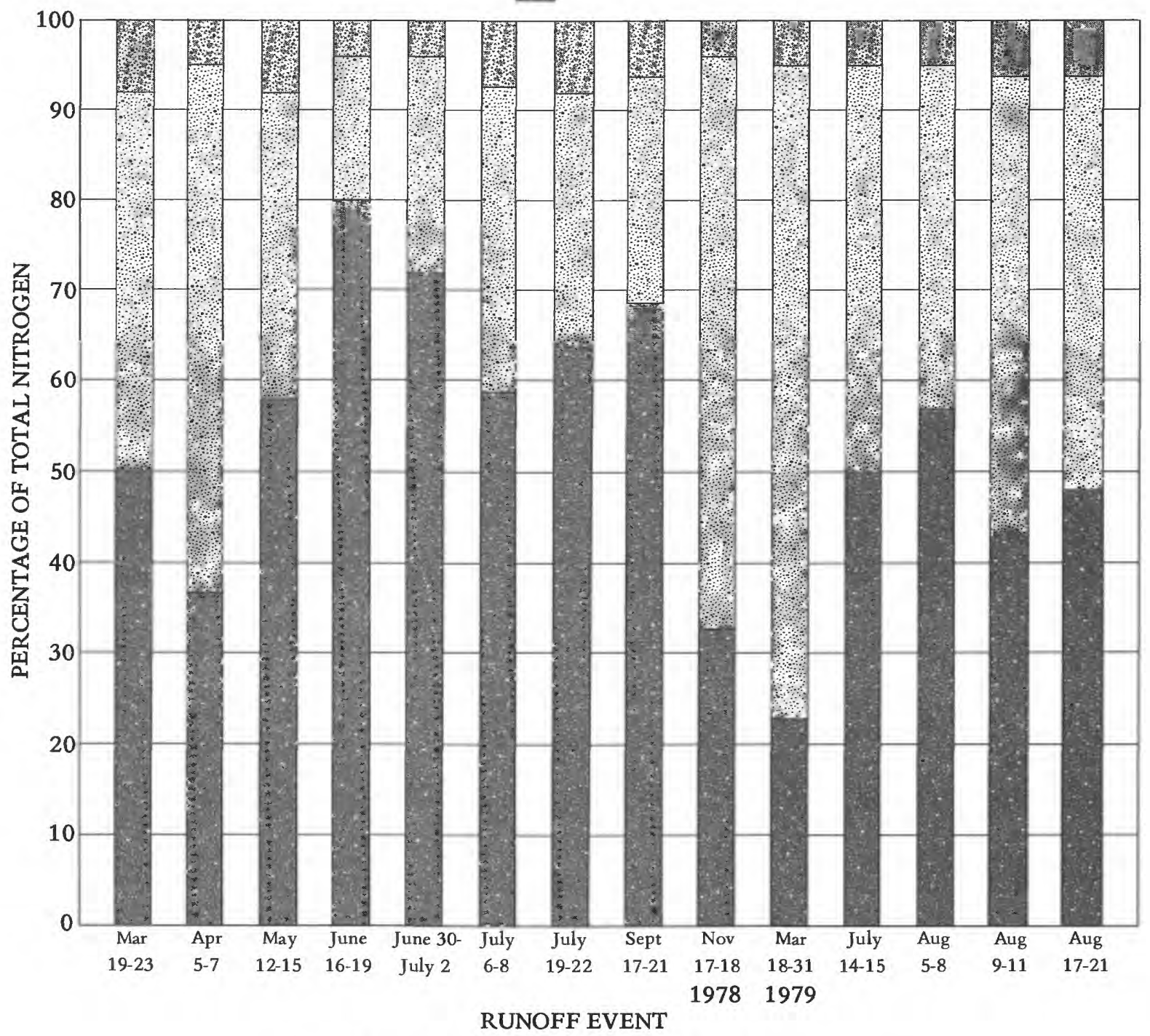

Figure 14. Constituent proportions of total nitrogen.

Figures 16 and 17 are accumulation curves for the nitrogen and phosphorus constituents, suspended sediment, and dissolved solids. The final point on each curve Indicates the total "load" for that particular constituent. The numbers located next to each line represent the percentage contribution of each constituent by direct runoff during sampled events. Direct runoff accounted for 29 percent of the total stream discharge. 

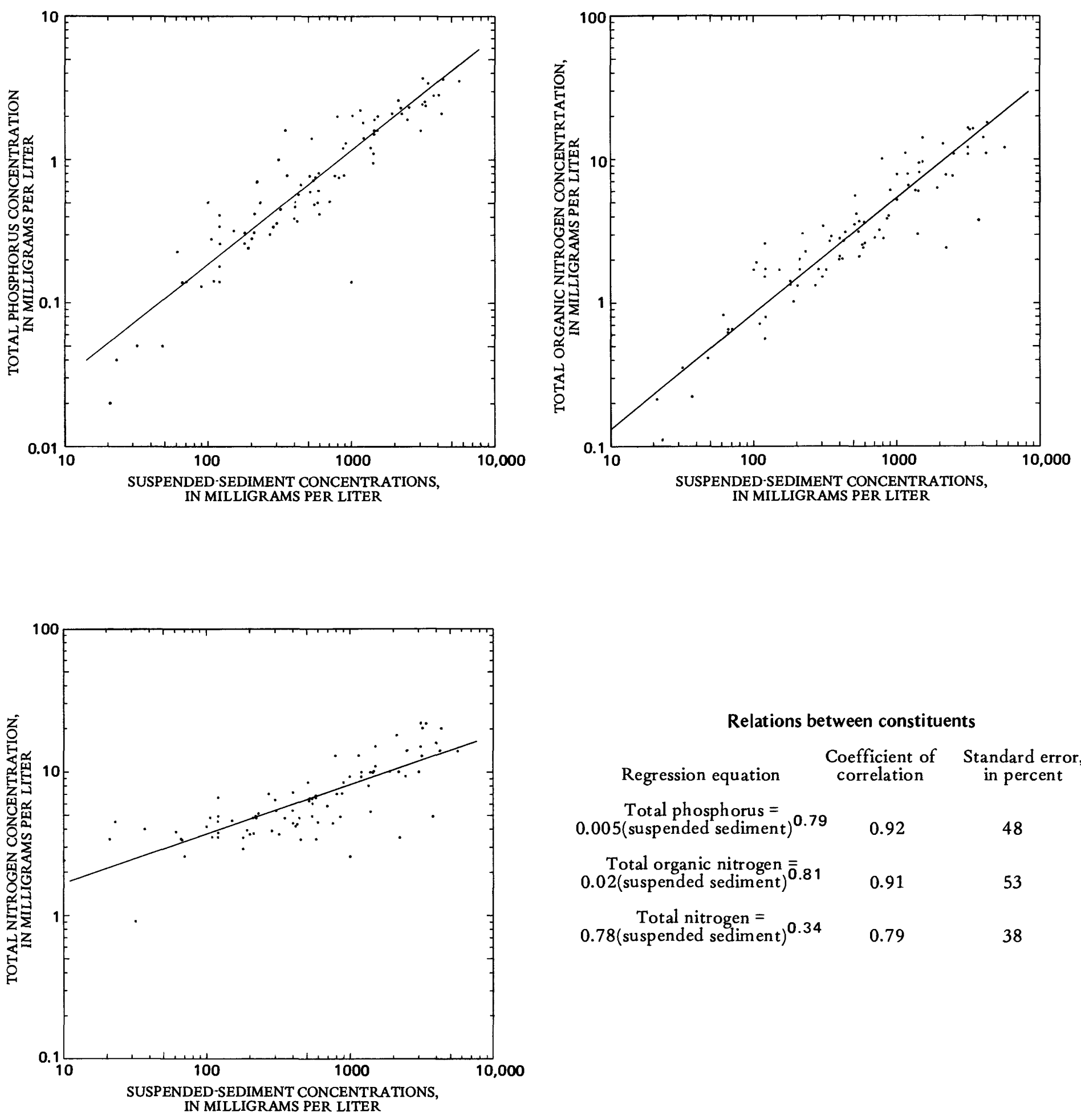

\section{Relations between constituents}

\begin{tabular}{|c|c|c|}
\hline Regression equation & $\begin{array}{l}\text { Coefficient of } \\
\text { correlation }\end{array}$ & $\begin{array}{l}\text { Standard error, } \\
\text { in percent }\end{array}$ \\
\hline $\begin{array}{c}\text { Total phosphorus }= \\
0.005(\text { suspended sediment })\end{array}$ & 0.92 & 48 \\
\hline $\begin{array}{c}\text { Total organic nitrogen } \\
0.02 \text { (suspended sediment) }\end{array}$ & 0.91 & 53 \\
\hline $\begin{array}{l}\text { Total nitrogen }= \\
0.78 \text { (suspended sediment) } \\
0.34\end{array}$ & 0.79 & 38 \\
\hline
\end{tabular}

Figure 15. Relation between chemical constituents and suspended sediment. 


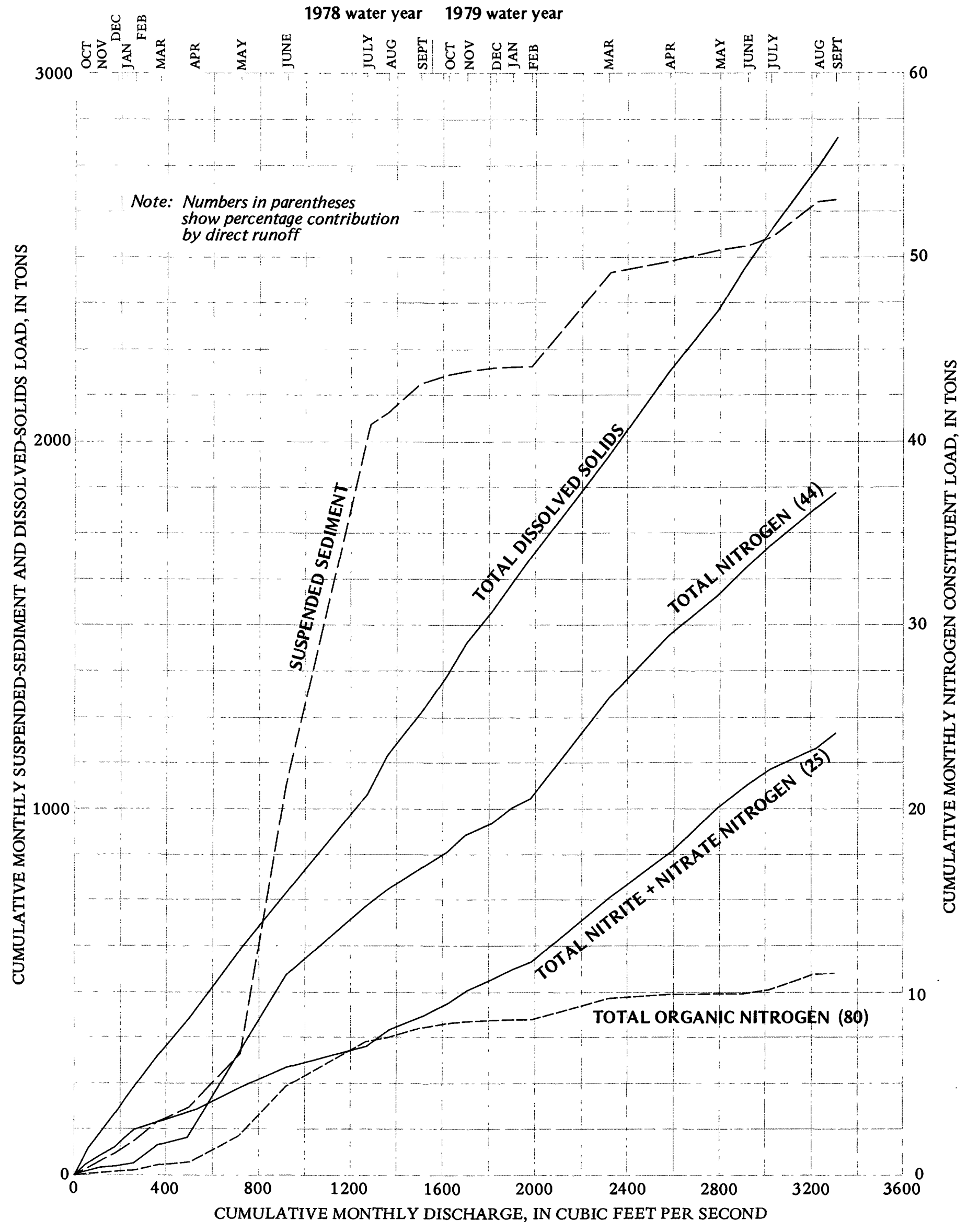

Figure 16. Double mass-accumulation curves for Steiner Branch for total dissolved solids, suspended sediment, total nitrogen, nitrite plus nitrate nitrogen, and organic nitrogen versus stream discharge. 


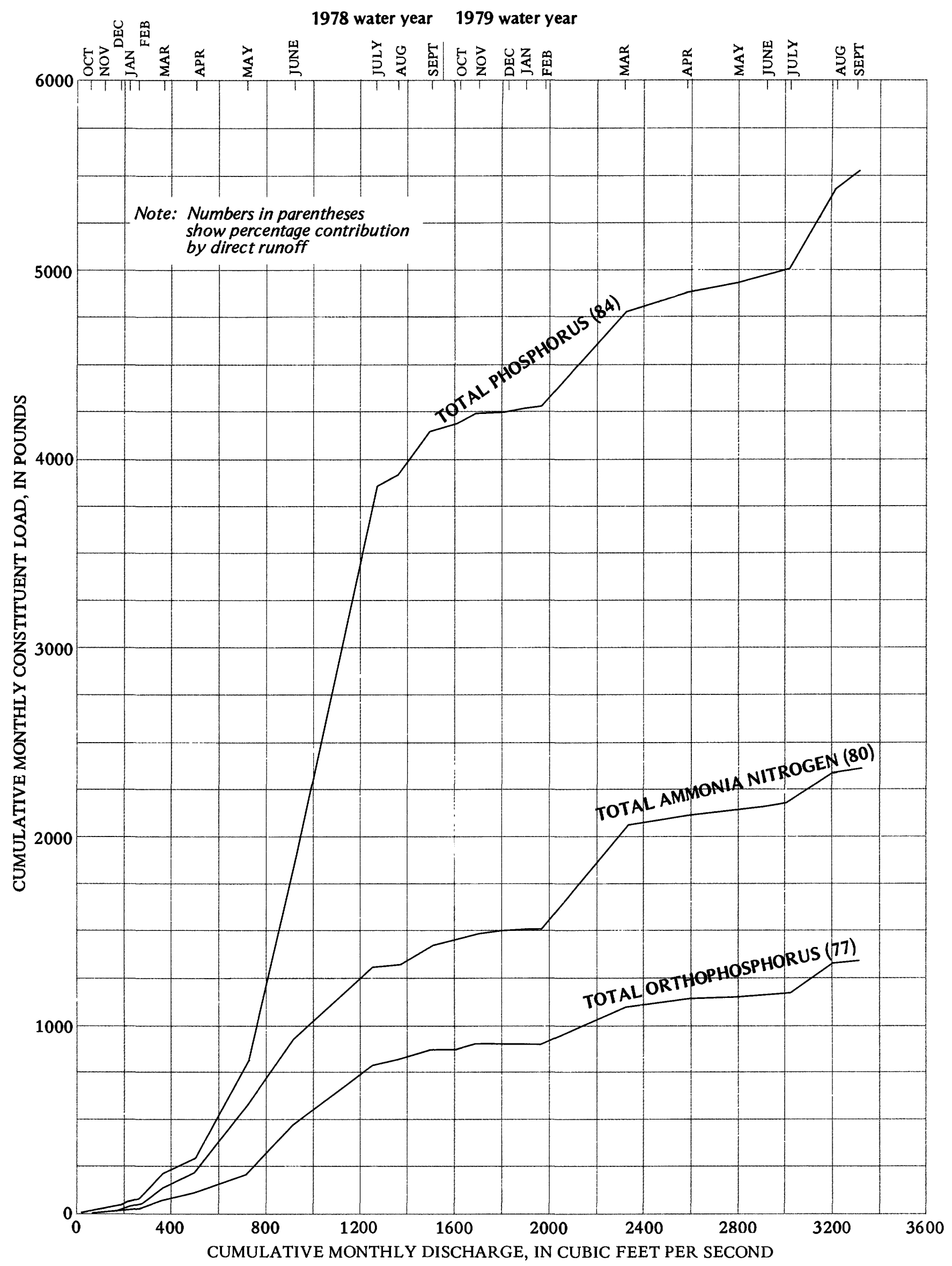

Figure 17. Double mass accumulation curves for Steiner Branch for total phosphorus, ammonia nitrogen, and ortho-phosphorus versus stream discharge. 
The slopes of the line segments indicate the proportional increase of the constituent loads with stream discharge. The relatively unchanging slope for the nitrite plus nitrate and dissolved solids curves indicates those constituent loads increased proportionately with stream discharge. The total nitrogen curve shows a similar pattern, most likely due to the dominance of nitrite plus nitrate in the total nitrogen values. The curves for the remainder of the constituents, however, demonstrate sharp slope changes, indicating a disproportionately large loading of these constituents with increasing stream discharge. For the few months without major runoff, the curves of the individual constituents show nearly the same slopes indicating little seasonal variation in the loading rates at medium and low stream discharges. Note the similarity of the curves for total phosphorus and suspended sediment. This almost exact duplication illustrates that phosphorus is transported to the stream in association with sediment particles.

The average daily yields for the various constituents, in pounds per square mile per day, are indicated in table 9. Maximum daily yields for each of the constituents are also shown in table 9. During sampled runoff events, average daily yields for total phosphorus increased as much as 170 times, for orthophosphorus as much as 110 times, and for organic nitrogen as much as 160 times. Daily loads of all constituents on Steiner Branch are shown in tables 12 through 19 .

Table 9. Average and maximum daily yields of nitrogen and phosphorus constituents for Steiner Branch.

\begin{tabular}{lcr} 
Constituent & $\begin{array}{c}\text { Average daily yield } \\
{\left[\left(1 \mathrm{~b} / \mathrm{mi}^{2}\right) / \mathrm{d}\right]}\end{array}$ & $\begin{array}{c}\text { Maximum daily yield } \\
{\left[\left(1 \mathrm{~b} / \mathrm{mi} \mathbf{2}^{2}\right) / \mathrm{d}\right]}\end{array}$ \\
\hline Total nitrogen & 17.3 & 1,016 \\
Organic nitrogen & 5.13 & 838 \\
Ammonia nitrogen & .55 & 47 \\
Nitrite + nitrate nitrogen & 9.57 & 131 \\
Total phosphorus & 1.29 & 219 \\
Orthophosphorus & .31 & 35 \\
\hline
\end{tabular}

Water temperature

Water temperature of Steiner Branch was recorded continuously. The daily maximum, minimum, and mean water temperatures and yearly values are shown in table 20 .

Although the minimum water temperature was $0.5^{\circ} \mathrm{C}$, the stream was ice covered during the winter. 


\section{Dissolved soilds}

Specific conductance of water of Steiner Branch was recorded continuously. The dally maximum, minimum, and mean specific conductivities and yearly values are shown in table 21. Specific conductance values generally have an inverse relationship to stream discharge and a good direct relationship to dissolved solids in a particular stream. In Steiner Branch, the relationship between specific conductance and dissolved solids was found to be

\section{$0.603 \mathrm{X}$ specific conductance $(\mu \mathrm{mho} / \mathrm{cm})=$ dissolved solids $(\mathrm{mg} / \mathrm{L})$}

Dissolved solids loads during the 2 water years were 1,250 and 1,580 tons, respectively. The higher load during the second year was due to increased baseflow discharges.

\section{Method comparison}

A comparison was made of methods for calculating loads of total nitrogen and total phosphorus. The first method used a bivariate regression equation deve1oped from all data points. Daily mean stream discharge was the independent variable, and daily phosphorus load in pounds was the dependent variable. The second method involved a series of "seasonal" regression analyses with the same variables as above to compute loads for unsampled periods and streamflow and concentration integration techniques (Porterfield, 1972) for the computation of sampled periods. The results from the second method were used in this report.

Annual loads for total nitrogen and total phosphorus computed by the two methods for the 1978 water year show good agreement. By the first method, the yearly totals for total nitrogen and total phosphorus were $35,0941 \mathrm{~b}$ and $3,255 \mathrm{lb}$, respectively. By the second method, the totals were $33,664 \mathrm{lb}$ and $4,177 \mathrm{lb}$, respectively--diferences of -4 percent and +22 percent.

\section{SUMMARY}

The U.S. Geological Survey, in cooperation with the Wisconsin Department of Natural Resources, investigated the water quality of the Steiner Branch basin in southwestern Wisconsin during the 1978 and 1979 water years. The $5.9 \mathrm{mi}^{2}$ basin has rugged mature topography, and agriculture is the principal land use. Corn, occupying 30 percent of the basin, is the major cash crop and is planted on steep soil slopes, most ranging from 6 to 20 percent. Few conservation practices to reduce soil erosion are followed.

Streamflow during the 1978 water year was about 90 percent of average despite the fact that precipitation was $5.04 \mathrm{in}$. above normal. Low ground-water levels during the 1978 water year contributed to low base flows. The 1978 water year had 10 storms in which rainfall was greater than 1.0 in., including 6 greater than $1.5 \mathrm{in}$.

Runoff for the 1979 water year was about 120 percent of average, but precipitation was 4.01 in. below normal. Ground-water recharge from the 1978-79 snowpack, that had a moisture content of 5.2 in. (a 50-year recurrence interva1), significantly increased base flow. Base runoff in the 1979 water 
year constituted 78 percent of the total runoff. Five storms having rainfall exceeding $1.0 \mathrm{in.,} \mathrm{including} \mathrm{two} \mathrm{greater} \mathrm{than} 1.5 \mathrm{in.,}$ occurred in the 1979 water year.

Streamflow ranged from $1.5 \mathrm{ft}^{3} / \mathrm{s}$, a 7-day low flow that occurs on the average of once every 2 years, to $392 \mathrm{ft} / \mathrm{s}$, a discharge of about a 5-year flood-recurrence interval.

Suspended-sediment yields from Steiner Branch basin were 369 ton/mi ${ }^{2}$ in the 1978 water year and $84.6 \mathrm{ton} / \mathrm{mi}^{2}$ in 1979 . The average yield ( $227 \mathrm{ton} / \mathrm{mi}{ }^{2}$ ) was 1.66 times greater than the average yield for the Yellowstone River basin, where more typical conservation practices are followed. The load per unit runoff from Steiner Branch basin was 1.30 times greater than from the Yellowstone River basin. The estimated long-term annual suspended-sediment yield for the Steiner Branch basin is $444 \mathrm{ton} / \mathrm{mi}^{2}$. Suspended-sediment concentrations ranged from 3 to $6,430 \mathrm{mg} / \mathrm{L}$.

A particle-size analysis of the suspended sediments showed 34 percent clay, 64 percent silt, and 2 percent sand. However, long-term analysis of particlesize data from the Yellowstone River indicate the percentages for clay should be more in the 65 to 75 percent range, whereas that for silt should be more in the 20 to 30 percent range.

The vegetation between the cornfields and the stream acts as a buffer and probably traps much of the sediment that could be transported to the stream. Without these vegetated areas sediment yields would probably be higher.

Most of the nutrient load, except for nitrite plus nitrate nitrogen and total nitrogen, was transported during runoff. The percentages transported during runoff are: total organic nitrogen, 80 percent; ammonia nitrogen, 80 percent; total phosphorus, 84 percent; and total orthophosphorus, 77 percent. Transport of nitrite plus nitrate nitrogen and total nitrogen occurred primarily during base-flow conditions, with 75 and 55 percent, respectively, of the total load for the study period being transported during these conditions. Total phosphorus, total orthophosphorus, ammonia nitrogen, and total organic nitrogen loadings were strongly similar to suspended-sediment loading in Steiner Branch. of the total nitrogen transported, 66 percent was nitrite plus nitrate; 30 percent was organic nitrogen; and 3 percent was ammonia nitrogen. of the tota1 phosphorus transported, 24 percent was orthophosphorus. Most of the remainder was organic phosphorus.

\section{REFERENCES}

Allord, G. J., 1979, Improving streamflow estimates through the use of Landsat: 5th Annual William T. Pecora Symposium, Proceedings, Sioux Falls, South Dakota, 4 p.

Bean, E. F., 1949, Geologic map of Wisconsin: Wisconsin Geological and Natura1 History Survey map. 
Batte11 Laboratories, 1971, Water quality criteria data book--Effects of chemicals on aquatic life: Government Printing Office, Washington, D.C., v. 3, 528 p.

Cahil1, T., 1977, Forms and sediment associations of nutrients (C.N. and $P_{\bullet}$ ) and metals, nutrients $-\mathrm{P}$. , in Shear, H., and Watson, A. E. P., eds., The fluvial transport of sediment-associated nutrients and contaminants: International Joint Commission, Workshop Proceedings, Kitchener, Ontario, 309 p.

Donigan, A. S., Jr., and Crawford, N. H., 1976, Modeling nonpoint pollution from the land surface: U.S. Envi ronmental Protection Agency, EPA-6003-76-083, 279 p.

Dunne, T., and Leopold, L. B., 1978, Water in environmental planning: San Francisco, Calif., W. H. Freeman and Company.

Environmental Data Service, 1973, Month1y normals of temperature, precipitation, and heating and cooling degree days for Wisconsin: Washington, D.C., U.S. Department of Commerce, Climatography of the United States, no. 81.

Guy, H. P., and Norman, V. W., 1970, Field methods for measurement of fluvial sediment: U.S. Geological Survey Techniques of Water Resources Investigations, Book 3, Chapter C2, 59 p.

Hinda11, S. M., 1975, Measurement and prediction of sediment yields in wisconsin streams: U.S. Geological Survey Water-Resources Investigations 54-75, $27 \mathrm{p}$.

Keliher, C., 1980, Informational letter: Lafayette County Soil and Water Conservation District.

K1ingelhoets, A. J., 1962, Soil survey of Iowa County, Wisconsin: Soil Conservation Service, Series No. 1958, no. 2, 101 p.

McE1roy, A. D., Chiu, S. Y., Nebgen, J. W., Aleti, A., and Bennett, F. W., 1976, Loading functions for assessment of water pollution from nonpoint sources: Midwest Research Institute, Kansas City, Missouri, U.S. Envi ronmenta1 Protection Agency Report EPA-600-2-76-151, 444 p.

National Academy of Sciences, National Academy of Engineering, 1973 [1974], Water quality criteria, 1972: U.S. Government Printing Office, 594 p.

Porterfield, G., 1972, Computation of fluvial-sediment discharge: U.S. Geological Survey Techniques of Water Resources Investigations, Book 3, Chapter C3, 66 p.

Sharpley, A. N., Syers, J. K., and O'Connor, P. W., 1976, Phosphorus inputs into a stream draining an agricultural watershed: Water, Air, and Soil Pollution, v. 6, p. 39-52. 
Stedfast, D. A., 1979, Low-flow characteristics of streams in the PecatonicaSugar River basin, Wisconsin: U.S. Geological Survey Water-Resources Investigations Open-File Report 79-1274, 92 p.

Thwaites, F. T., 1963, Outline of glacial geology: Ann Arbor, Mich., Edwards Bros., Inc., 142 p.

United States Congress, 1972, Federal water pollution control act amendments of 1972, Public Law 92-500, section 208: U.S. 92d Congress, 2d session, p. 25-26.

U.S. Department of Commerce, 1964, Frequency of maximum water equivalents of March snow content in north-central United States: U.S. Department of Commerce Technical Paper no. 50.

U.S. Environmental Protection Agency, 1976, Quality criteria for water: U.S. Envi ronmental Protection Agency, Washington, D.C., 256 p.

U.S. Geological Survey, 1980, Water resources data for Wisconsin, 1979: U.S. Geologica1 Survey Water-Data Report WI-79-1, 514 p.

Verhoff, F. G., Melfi, D. A., and Yalesick, S. M., 1979, Storm travel distance calculations for total phosphorus and suspended material in rivers: Water Resources Research, v. 15, no. 6, p. 1,354-1,360.

Ward, J. R., and Eckhardt, D. A., 1979, Nonpoint-source discharges in Pequea Creek basin, Pennsylvania, 1977: U.S. Geologica1 Survey Water-Resources Investigations 79-88, $110 \mathrm{p}$.

Watson, B. G., 1966, Soil survey of Lafayette County, Wisconsin: Soil Convervation Service, Series 1960, no. 27, 137 p.

Weber, C. I., 1973, Recent developments in the measurement of the response of plankton and periphyton to changes in their environment, in Glass, G., ed., Bioassay techniques and environmental chemistry: Ann Arbor Science Publishers, Inc., p. 119-138.

Wisconsin Department of Agriculture, 1961, Wisconsin climatological data: Wisconsin Crop Reporting Service Publication, 168 p. (approx.).

Wisconsin Department of Natural Resources, 1976, DNR information paper on nonpoint source pollution: Department of Natural Resources, 5 p. 
Table 10. Stream discharges for Steiner Branch, 1978 and 1979 water years.

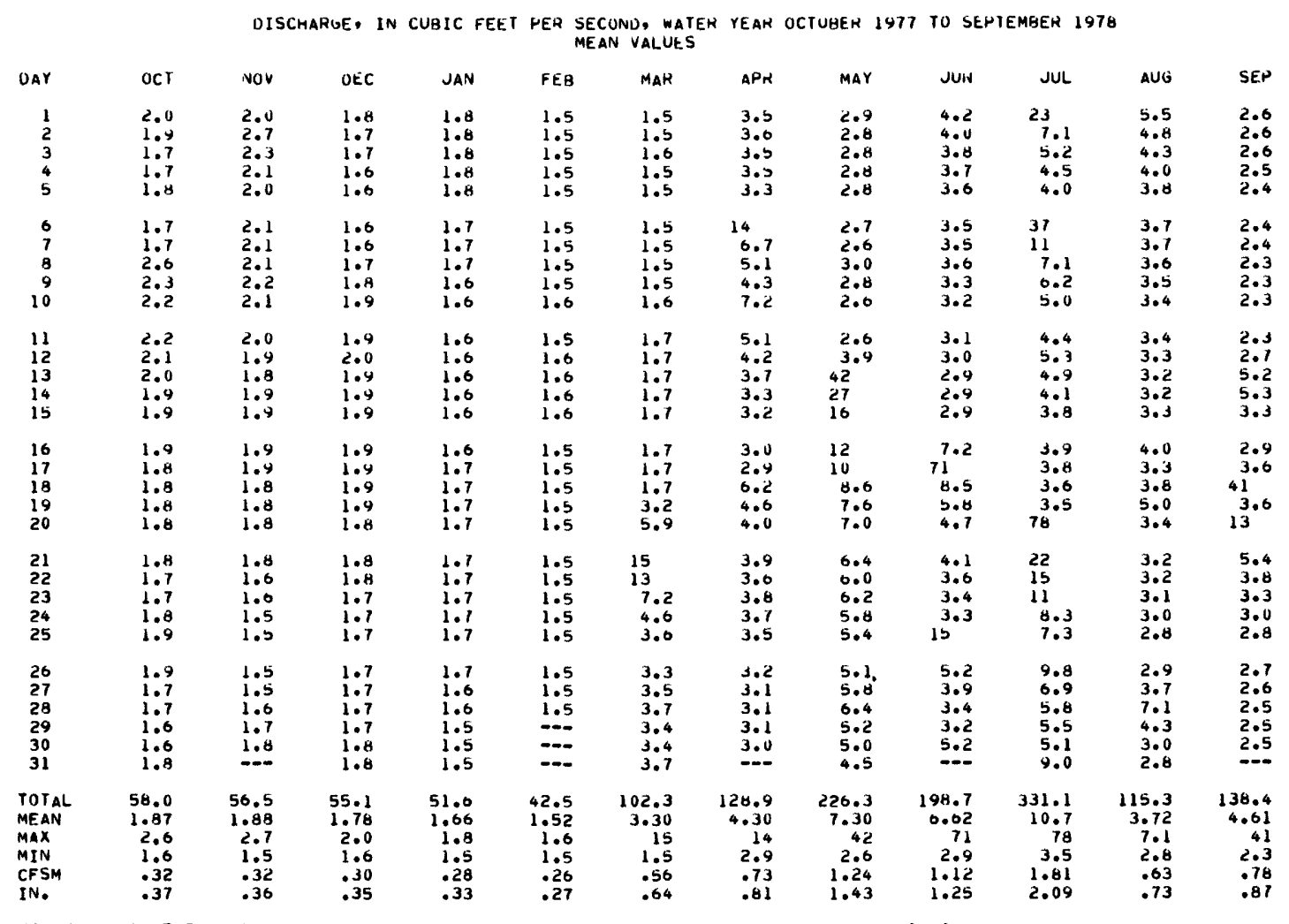

WTR YR 1978 TUTAL ISU4.7 MEAN 4.12 MAX 78 MIN 1.5 CFSM .70 IN 9.49

\begin{tabular}{|c|c|c|c|c|c|c|c|c|c|c|c|c|}
\hline \multirow[b]{2}{*}{ DAY } & \multirow[b]{2}{*}{ OCT } & \multicolumn{2}{|c|}{ DISCHARGE, I } & \multicolumn{2}{|c|}{ CUBIC FEET PER } & $\begin{array}{l}\text { SECOND, WATE } \\
\text { MEAN VALUES }\end{array}$ & \multicolumn{5}{|l|}{$R$} & \multirow[b]{2}{*}{ SEP } \\
\hline & & Nov & DEC & JAN & FEB & MAR & APR & MAY & JUN & JUL & AUG & \\
\hline $\begin{array}{l}1 \\
2 \\
3 \\
4 \\
5\end{array}$ & $\begin{array}{l}3.0 \\
3.2 \\
3.6 \\
3.2 \\
3.8\end{array}$ & $\begin{array}{l}3.4 \\
3.4 \\
3.4 \\
3.4 \\
3.4\end{array}$ & $\begin{array}{l}3.2 \\
3.2 \\
3.6 \\
3.5 \\
3.4\end{array}$ & $\begin{array}{l}2.6 \\
2.5 \\
2.5 \\
2.4 \\
2.4\end{array}$ & $\begin{array}{l}2.5 \\
2.3 \\
2.4 \\
2.4 \\
2.4\end{array}$ & $\begin{array}{l}2.9 \\
2.9 \\
3.3 \\
3.7 \\
3.6\end{array}$ & $\begin{array}{l}14 \\
15 \\
12 \\
12 \\
11\end{array}$ & $\begin{array}{l}0.7 \\
7.7 \\
9.6 \\
8.4 \\
8.3\end{array}$ & $\begin{array}{l}4.9 \\
4.7 \\
4.7 \\
4.7 \\
4.8\end{array}$ & $\begin{array}{l}4.1 \\
4.1 \\
3.9 \\
4.4 \\
3.5\end{array}$ & $\begin{array}{c}3.1 \\
3.1 \\
3.7 \\
3.8 \\
13\end{array}$ & $\begin{array}{l}4.2 \\
4.1 \\
4.0 \\
4.5 \\
3.7\end{array}$ \\
\hline $\begin{array}{r}6 \\
7 \\
8 \\
9 \\
10\end{array}$ & $\begin{array}{l}3.5 \\
3.2 \\
3.2 \\
4.4 \\
4.2\end{array}$ & $\begin{array}{l}3.4 \\
3.2 \\
3.2 \\
3.2 \\
3.2\end{array}$ & $\begin{array}{l}3.2 \\
3.3 \\
3.2 \\
3.0 \\
2.9\end{array}$ & $\begin{array}{l}2.4 \\
2.4 \\
2.5 \\
2.5 \\
2.4\end{array}$ & $\begin{array}{l}2.5 \\
2.5 \\
2.4 \\
2.4 \\
2.4\end{array}$ & $\begin{array}{l}3.5 \\
3.6 \\
3.4 \\
3.3 \\
3.2\end{array}$ & $\begin{array}{l}12 \\
9.5 \\
9.7 \\
9.3 \\
8.6\end{array}$ & $\begin{array}{l}8.3 \\
8.1 \\
7.8 \\
7.3 \\
6.9\end{array}$ & $\begin{array}{l}4.5 \\
4.6 \\
4.6 \\
4.6 \\
5.4\end{array}$ & $\begin{array}{l}3.4 \\
3.4 \\
3.3 \\
3.3 \\
3.3\end{array}$ & $\begin{array}{l}3.7 \\
2.8 \\
2.8 \\
11 \\
14\end{array}$ & $\begin{array}{l}3.6 \\
3.8 \\
3.8 \\
3.7 \\
3.8\end{array}$ \\
\hline $\begin{array}{l}11 \\
12 \\
13 \\
14 \\
15\end{array}$ & $\begin{array}{l}3.8 \\
3.5 \\
3.3 \\
3.2 \\
3.3\end{array}$ & $\begin{array}{l}3.1 \\
3.0 \\
5.6 \\
4.0 \\
3.6\end{array}$ & $\begin{array}{l}3.1 \\
3.2 \\
3.1 \\
3.1 \\
3.1\end{array}$ & $\begin{array}{l}2.3 \\
2.4 \\
2.6 \\
2.5 \\
2.5\end{array}$ & $\begin{array}{l}2.4 \\
2.4 \\
2.4 \\
2.4 \\
2.4\end{array}$ & $\begin{array}{l}3.3 \\
3.5 \\
3.8 \\
4.1 \\
4.0\end{array}$ & $\begin{array}{l}8.8 \\
9.8 \\
9.4 \\
8.6 \\
8.0\end{array}$ & $\begin{array}{l}7.0 \\
6.5 \\
6.3 \\
6.2 \\
5.9\end{array}$ & $\begin{array}{l}4.6 \\
4.4 \\
4.3 \\
4.2 \\
4.2\end{array}$ & $\begin{array}{l}3.3 \\
3.3 \\
3.6 \\
8.4 \\
3.8\end{array}$ & $\begin{array}{l}5.4 \\
4.6 \\
4.4 \\
4.2 \\
4.0\end{array}$ & $\begin{array}{l}3.5 \\
3.4 \\
3.3 \\
3.2 \\
3.1\end{array}$ \\
\hline $\begin{array}{l}16 \\
17 \\
18 \\
19 \\
20\end{array}$ & $\begin{array}{l}3.4 \\
3.3 \\
3.4 \\
3.4 \\
3.5\end{array}$ & $\begin{array}{l}3.4 \\
8.3 \\
5.1 \\
4.2 \\
3.8\end{array}$ & $\begin{array}{l}3.1 \\
3.0 \\
3.0 \\
3.0 \\
3.0\end{array}$ & $\begin{array}{l}2.4 \\
2.5 \\
2.7 \\
2.8 \\
2.9\end{array}$ & $\begin{array}{l}2.3 \\
2.4 \\
2.4 \\
2.4 \\
2.4\end{array}$ & $\begin{array}{l}3.9 \\
4.0 \\
7.4 \\
31 \\
28\end{array}$ & $\begin{array}{l}7.8 \\
7.6 \\
7.2 \\
7.2 \\
7.4\end{array}$ & $\begin{array}{l}5.7 \\
5.7 \\
5.9 \\
6.8 \\
5.8\end{array}$ & $\begin{array}{l}4.1 \\
4.0 \\
4.1 \\
4.1 \\
4.7\end{array}$ & $\begin{array}{l}3.4 \\
3.3 \\
3.2 \\
3.1 \\
3.1\end{array}$ & $\begin{array}{c}3.8 \\
7.6 \\
11 \\
5.6 \\
10\end{array}$ & $\begin{array}{l}3.1 \\
3.2 \\
3.2 \\
3.0 \\
3.2\end{array}$ \\
\hline $\begin{array}{l}21 \\
22 \\
23 \\
24 \\
25\end{array}$ & $\begin{array}{l}3.6 \\
3.5 \\
3.6 \\
3.7 \\
4.1\end{array}$ & $\begin{array}{l}3.6 \\
3.5 \\
3.8 \\
3.6 \\
3.4\end{array}$ & $\begin{array}{l}3.2 \\
2.9 \\
2.9 \\
2.8 \\
2.8\end{array}$ & $\begin{array}{l}3.0 \\
3.0 \\
2.9 \\
2.8 \\
2.8\end{array}$ & $\begin{array}{l}2.5 \\
2.5 \\
3.2 \\
3.0 \\
2.9\end{array}$ & $\begin{array}{l}21 \\
25 \\
36 \\
28 \\
19\end{array}$ & $\begin{array}{l}7.2 \\
6.8 \\
6.6 \\
6.6 \\
7.0\end{array}$ & $\begin{array}{l}5.5 \\
5.5 \\
5.6 \\
5.3 \\
5.2\end{array}$ & $\begin{array}{l}4.2 \\
4.0 \\
4.0 \\
3.9 \\
3.8\end{array}$ & $\begin{array}{l}3.1 \\
3.8 \\
3.2 \\
3.3 \\
3.6\end{array}$ & $\begin{array}{l}6.2 \\
6.4 \\
5.4 \\
5.0 \\
4.7\end{array}$ & $\begin{array}{l}3.0 \\
2.9 \\
3.0 \\
3.0 \\
3.0\end{array}$ \\
\hline $\begin{array}{l}26 \\
27 \\
28 \\
29 \\
30 \\
31\end{array}$ & $\begin{array}{l}4.0 \\
3.8 \\
3.7 \\
3.6 \\
3.6 \\
3.6\end{array}$ & $\begin{array}{l}3.4 \\
3.4 \\
3.3 \\
3.4 \\
3.4 \\
-.0\end{array}$ & $\begin{array}{l}2.8 \\
2.7 \\
2.8 \\
2.8 \\
2.7 \\
2.7\end{array}$ & $\begin{array}{l}2.8 \\
2.7 \\
2.5 \\
2.3 \\
2.6 \\
2.4\end{array}$ & $\begin{array}{l}2.8 \\
2.8 \\
2.8 \\
-2 . \\
--0 \\
--0\end{array}$ & $\begin{array}{l}14 \\
12 \\
12 \\
18 \\
22 \\
17\end{array}$ & $\begin{array}{l}8.0 \\
7.4 \\
7.2 \\
7.2 \\
7.2 \\
-.2\end{array}$ & $\begin{array}{l}5.3 \\
5.3 \\
5.1 \\
5.0 \\
5.0 \\
5.0\end{array}$ & $\begin{array}{l}3.8 \\
3.8 \\
3.9 \\
4.3 \\
4.2 \\
-. .-\end{array}$ & $\begin{array}{l}3.3 \\
3.1 \\
3.1 \\
3.1 \\
4.3 \\
3.3\end{array}$ & $\begin{array}{l}4.5 \\
5.2 \\
4.7 \\
5.3 \\
4.4 \\
4.2\end{array}$ & $\begin{array}{l}2.8 \\
2.7 \\
2.6 \\
2.8 \\
2.6 \\
\end{array}$ \\
\hline $\begin{array}{l}\text { TOTAL } \\
\text { MEAN } \\
\text { MAX } \\
\text { MIN } \\
\text { CFSM } \\
\text { IN. }\end{array}$ & $\begin{array}{r}110.2 \\
3.55 \\
4.4 \\
3.0 \\
.60 \\
.69\end{array}$ & $\begin{array}{r}112.1 \\
3.74 \\
8.3 \\
3.0 \\
.63 \\
.71\end{array}$ & $\begin{array}{r}94.3 \\
3.04 \\
3.6 \\
2.7 \\
.52 \\
.59\end{array}$ & $\begin{array}{r}80.0 \\
2.58 \\
3.0 \\
2.3 \\
.44 \\
.50\end{array}$ & $\begin{array}{r}70.6 \\
2.52 \\
3.2 \\
2.3 \\
.43 \\
.45\end{array}$ & $\begin{array}{r}350.4 \\
11.3 \\
36 \\
2.9 \\
1.92 \\
2.21\end{array}$ & $\begin{array}{r}260.1 \\
8.87 \\
15 \\
6.6 \\
1.50 \\
1.68\end{array}$ & $\begin{array}{r}198.7 \\
6.41 \\
9.6 \\
5.0 \\
1.09 \\
1.25\end{array}$ & $\begin{array}{r}130.1 \\
4.34 \\
5.4 \\
3.8 \\
.74 \\
.82\end{array}$ & $\begin{array}{r}112.4 \\
3.63 \\
8.4 \\
3.1 \\
.62 \\
.71\end{array}$ & $\begin{array}{r}177.6 \\
5.73 \\
14 \\
2.8 \\
.97 \\
1.12\end{array}$ & $\begin{array}{r}99.8 \\
3.33 \\
4.5 \\
2.6 \\
.56 \\
.6 .3\end{array}$ \\
\hline
\end{tabular}

$\begin{array}{llllllllll}\text { CAL YR } 1978 & \text { TOTAL } 1651.7 & \text { MEAN } 4.53 & \text { MAX } 78 & \text { MIN } 1.5 & \text { CF5M .77 } & \text { IN } 10.41 \\ \text { WTR YR } 1979 & \text { TOTAL } & 1802.3 & \text { MEAN } 4.94 & \text { MAX } 36 & \text { MIN } 2.3 & \text { CFSM .84 } & \text { IN } 11.36\end{array}$ 
Table 11. Stream discharges for Yellowstone River, 1978 and 1979 water years.

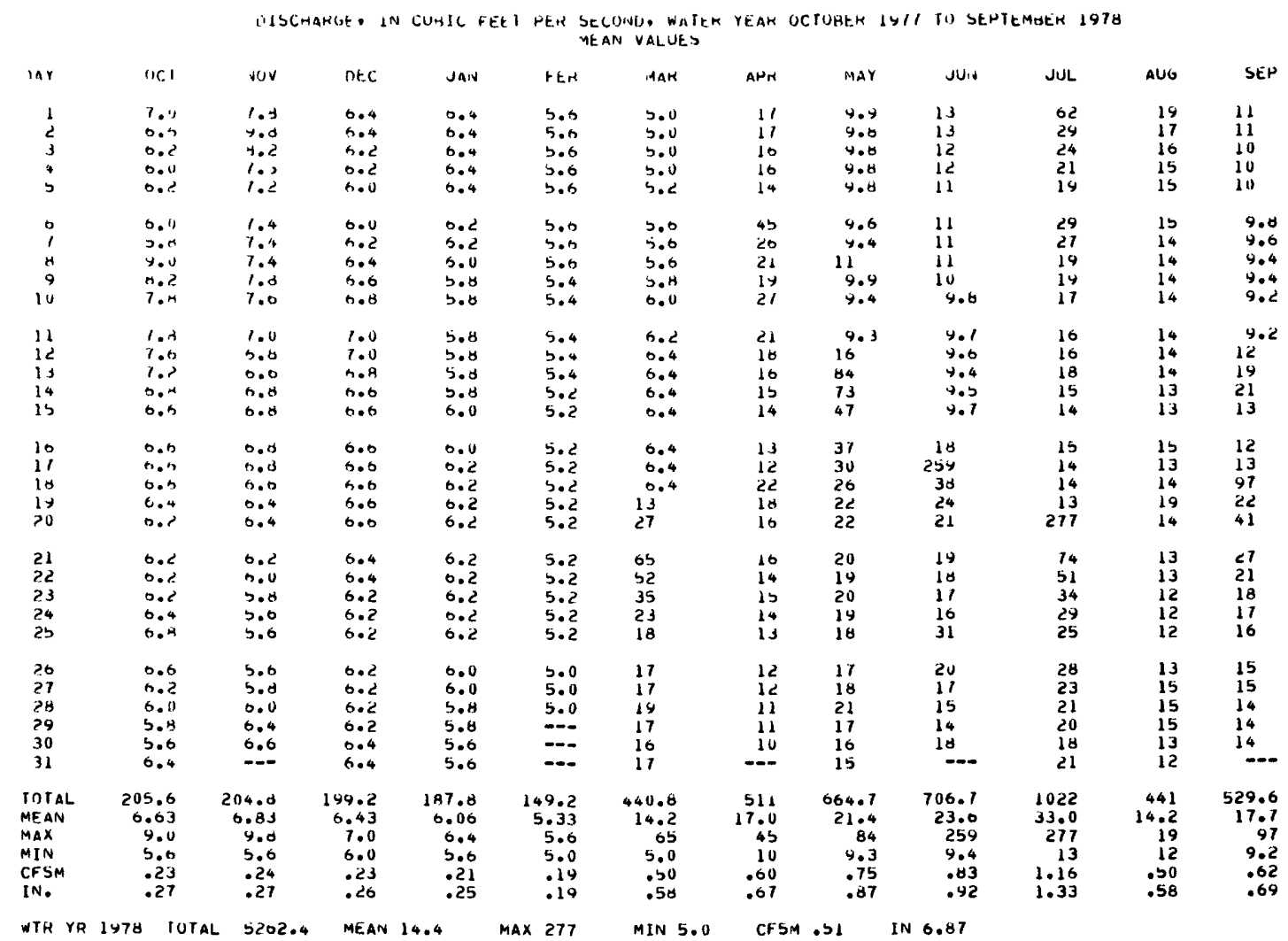

DISCHARGE, IN CUBIC FEET PER SECOND, WATER YEAK OCTOBEH 1978 TU SEPTEMEER 1979

\begin{tabular}{|c|c|c|c|c|c|c|c|c|c|c|c|c|}
\hline OAY & $\mathrm{OCT}$ & Nov & DEC & JAN & FEB & MAK & APH & MAY & JUN & JUL & AUG & SEP \\
\hline $\begin{array}{l}1 \\
2 \\
3 \\
4 \\
5\end{array}$ & $\begin{array}{l}13 \\
14 \\
16 \\
14 \\
15\end{array}$ & $\begin{array}{l}12 \\
12 \\
11 \\
11 \\
12\end{array}$ & $\begin{array}{l}12 \\
11 \\
12 \\
12 \\
12\end{array}$ & $\begin{array}{l}9.2 \\
8.6 \\
8.4 \\
8.2 \\
8.0\end{array}$ & $\begin{array}{l}9.0 \\
8.4 \\
8.2 \\
8.2 \\
8.2\end{array}$ & $\begin{array}{l}10 \\
10 \\
12 \\
13 \\
12\end{array}$ & $\begin{array}{l}56 \\
55 \\
49 \\
47 \\
45\end{array}$ & $\begin{array}{l}25 \\
27 \\
35 \\
28 \\
27\end{array}$ & $\begin{array}{l}18 \\
18 \\
18 \\
18 \\
18\end{array}$ & $\begin{array}{l}15 \\
14 \\
19 \\
27 \\
15\end{array}$ & $\begin{array}{l}14 \\
14 \\
17 \\
15 \\
47\end{array}$ & $\begin{array}{l}18 \\
18 \\
17 \\
17 \\
16\end{array}$ \\
\hline $\begin{array}{r}6 \\
7 \\
8 \\
9 \\
10\end{array}$ & $\begin{array}{l}14 \\
14 \\
13 \\
17 \\
17\end{array}$ & $\begin{array}{l}12 \\
11 \\
11 \\
11 \\
11\end{array}$ & $\begin{array}{l}11 \\
11 \\
11 \\
10 \\
10\end{array}$ & $\begin{array}{l}8.2 \\
8.2 \\
8.4 \\
8.6 \\
8.2\end{array}$ & $\begin{array}{l}8.6 \\
8.6 \\
8.6 \\
8.2 \\
8.2\end{array}$ & $\begin{array}{l}13 \\
12 \\
11 \\
11 \\
11\end{array}$ & $\begin{array}{r}38 \\
38 \\
39 \\
37 \\
37 \\
34\end{array}$ & $\begin{array}{l}26 \\
25 \\
25 \\
24 \\
23\end{array}$ & $\begin{array}{l}18 \\
18 \\
18 \\
18 \\
21\end{array}$ & $\begin{array}{l}15 \\
14 \\
14 \\
14 \\
14\end{array}$ & $\begin{array}{l}20 \\
16 \\
22 \\
62 \\
56\end{array}$ & $\begin{array}{l}15 \\
15 \\
15 \\
15 \\
15\end{array}$ \\
\hline $\begin{array}{l}11 \\
12 \\
13 \\
14 \\
15\end{array}$ & $\begin{array}{l}15 \\
15 \\
14 \\
14 \\
14\end{array}$ & $\begin{array}{l}11 \\
11 \\
21 \\
14 \\
12\end{array}$ & $\begin{array}{l}11 \\
12 \\
11 \\
11 \\
11\end{array}$ & $\begin{array}{l}8.0 \\
8.4 \\
8.8 \\
8.6 \\
8.4\end{array}$ & $\begin{array}{l}8.2 \\
8.4 \\
8.4 \\
8.6 \\
8.8\end{array}$ & $\begin{array}{l}11 \\
11 \\
13 \\
15 \\
13\end{array}$ & $\begin{array}{l}35 \\
37 \\
33 \\
31 \\
29\end{array}$ & $\begin{array}{l}24 \\
22 \\
22 \\
21 \\
20\end{array}$ & $\begin{array}{l}18 \\
17 \\
17 \\
16 \\
16\end{array}$ & $\begin{array}{l}16 \\
15 \\
15 \\
27 \\
16\end{array}$ & $\begin{array}{l}24 \\
20 \\
19 \\
18 \\
17\end{array}$ & $\begin{array}{l}14 \\
14 \\
14 \\
14 \\
14\end{array}$ \\
\hline $\begin{array}{l}16 \\
17 \\
18 \\
19 \\
20\end{array}$ & $\begin{array}{l}14 \\
13 \\
14 \\
13 \\
13\end{array}$ & $\begin{array}{l}12 \\
28 \\
19 \\
15 \\
14\end{array}$ & $\begin{array}{l}11 \\
10 \\
11 \\
11 \\
11\end{array}$ & $\begin{array}{l}8.2 \\
8.6 \\
8.8 \\
9.2 \\
9.6\end{array}$ & $\begin{array}{l}8.4 \\
8.2 \\
8.2 \\
8.2 \\
8.4\end{array}$ & $\begin{array}{r}13 \\
14 \\
37 \\
185 \\
136\end{array}$ & $\begin{array}{l}28 \\
27 \\
26 \\
25 \\
27\end{array}$ & $\begin{array}{l}20 \\
19 \\
20 \\
25 \\
20\end{array}$ & $\begin{array}{l}16 \\
16 \\
16 \\
16 \\
19\end{array}$ & $\begin{array}{l}15 \\
14 \\
14 \\
14 \\
14\end{array}$ & $\begin{array}{l}17 \\
35 \\
52 \\
26 \\
46\end{array}$ & $\begin{array}{l}14 \\
14 \\
13 \\
13 \\
14\end{array}$ \\
\hline $\begin{array}{l}21 \\
22 \\
23 \\
24 \\
25\end{array}$ & $\begin{array}{l}13 \\
13 \\
13 \\
12 \\
14\end{array}$ & $\begin{array}{l}13 \\
13 \\
14 \\
13 \\
13\end{array}$ & $\begin{array}{l}9.6 \\
9.9 \\
9.7 \\
9.8 \\
9.7\end{array}$ & $\begin{array}{l}10 \\
10 \\
9.8 \\
9.6 \\
9.4\end{array}$ & $\begin{array}{l}8.6 \\
10 \\
11 \\
11 \\
10\end{array}$ & $\begin{array}{r}96 \\
106 \\
142 \\
99 \\
70\end{array}$ & $\begin{array}{l}27 \\
25 \\
24 \\
24 \\
27\end{array}$ & $\begin{array}{l}19 \\
19 \\
20 \\
19 \\
19\end{array}$ & $\begin{array}{l}16 \\
15 \\
15 \\
15 \\
14\end{array}$ & $\begin{array}{l}14 \\
18 \\
14 \\
14 \\
15\end{array}$ & $\begin{array}{l}30 \\
31 \\
25 \\
23 \\
21\end{array}$ & $\begin{array}{l}13 \\
13 \\
13 \\
14 \\
14\end{array}$ \\
\hline $\begin{array}{l}26 \\
27 \\
28 \\
29 \\
30 \\
31\end{array}$ & $\begin{array}{l}13 \\
12 \\
12 \\
12 \\
12 \\
12\end{array}$ & $\begin{array}{r}12 \\
13 \\
12 \\
13 \\
12 \\
-\end{array}$ & $\begin{array}{l}9.4 \\
9.2 \\
9.4 \\
9.4 \\
9.7 \\
9.2\end{array}$ & $\begin{array}{l}9.6 \\
9.8 \\
9.0 \\
8.4 \\
9.0 \\
9.2\end{array}$ & $\begin{array}{l}9.8 \\
9.8 \\
10 \\
0 \\
0\end{array}$ & $\begin{array}{l}56 \\
50 \\
49 \\
70 \\
86 \\
65\end{array}$ & $\begin{array}{r}30 \\
25 \\
26 \\
26 \\
28 \\
--0\end{array}$ & $\begin{array}{l}19 \\
19 \\
18 \\
18 \\
18 \\
18\end{array}$ & $\begin{array}{r}14 \\
14 \\
15 \\
17 \\
16 \\
-\end{array}$ & $\begin{array}{l}14 \\
14 \\
13 \\
13 \\
23 \\
15\end{array}$ & $\begin{array}{l}20 \\
22 \\
20 \\
26 \\
19 \\
18\end{array}$ & $\begin{array}{r}13 \\
13 \\
13 \\
13 \\
13 \\
-13\end{array}$ \\
\hline $\begin{array}{l}\text { TOTAL } \\
\text { MEAN } \\
\text { MAX } \\
\text { MIN } \\
\text { CFSM } \\
\text { IN. }\end{array}$ & $\begin{array}{r}424 \\
13.7 \\
17 \\
12 \\
.48 \\
.55\end{array}$ & $\begin{array}{r}399 \\
13.3 \\
28 \\
11 \\
.47 \\
.52\end{array}$ & $\begin{array}{r}327.0 \\
10.5 \\
12 \\
9.2 \\
.37 \\
.43\end{array}$ & $\begin{array}{r}274.4 \\
8.85 \\
10 \\
8.0 \\
.31 \\
.36\end{array}$ & $\begin{array}{r}248.2 \\
8.86 \\
11 \\
8.2 \\
.31 \\
.32\end{array}$ & $\begin{array}{r}1452 \\
46.8 \\
185 \\
10 \\
1.64 \\
1.90\end{array}$ & $\begin{array}{r}998 \\
33.3 \\
56 \\
24 \\
1.11 \\
1.30\end{array}$ & $\begin{array}{r}684 \\
22.1 \\
35 \\
18 \\
.78 \\
.89\end{array}$ & $\begin{array}{r}501 \\
16.7 \\
21 \\
14 \\
.59 \\
.65\end{array}$ & $\begin{array}{r}488 \\
15.7 \\
27 \\
13 \\
.55 \\
.64\end{array}$ & $\begin{array}{r}812 \\
26.2 \\
62 \\
14 \\
.92 \\
1.06\end{array}$ & $\begin{array}{r}431 \\
14.4 \\
18 \\
13 \\
.51 \\
.56\end{array}$ \\
\hline
\end{tabular}

$\begin{array}{llllllllll}\text { CAL YR } 1978 & \text { TOTAL } & 5802.8 & \text { MEAN } 15.9 & \text { MAX } 277 & \text { MIN } 5.0 & \text { CFSM .56 } & \text { IN } 7.57 \\ \text { WTR YR } 1979 & \text { TOTAL } & 7038.6 & \text { MEAN } 19.3 & \text { MAX } 185 & \text { MIN } 8.0 & \text { CFSM } & .68 & \text { IN } 9.19\end{array}$ 
Table 12. Suspended-sediment discharges for Steiner Branch, 1978 and 1979 water years.

\begin{tabular}{|c|c|c|c|c|c|c|c|c|c|c|c|c|}
\hline \multirow[t]{2}{*}{ DAY } & $\begin{array}{l}\text { MEAN } \\
\text { CONCEN- } \\
\text { TRATION } \\
\text { (MGLL) }\end{array}$ & $\begin{array}{l}\text { LOADS } \\
\text { (T/DAY) }\end{array}$ & $\begin{array}{l}\text { MEAN } \\
\text { CONCEN- } \\
\text { TRATION } \\
\text { (MG/L) }\end{array}$ & $\begin{array}{l}\text { LOADS } \\
\text { (T/OAY) }\end{array}$ & $\begin{array}{l}\text { MEAN } \\
\text { CUNCEN- } \\
\text { THATION } \\
\text { (MG/L) }\end{array}$ & $\begin{array}{l}\text { LOADS } \\
\text { (T/NAY) }\end{array}$ & $\begin{array}{l}\text { MEAN } \\
\text { CONCEN- } \\
\text { TRAIION } \\
\text { (MGLL) }\end{array}$ & $\begin{array}{l}\text { LOADS } \\
\text { (T/NAYY }\end{array}$ & $\begin{array}{l}\text { MEAN } \\
\text { CONCEN- } \\
\text { TRATION } \\
\text { (MGLL) }\end{array}$ & $\begin{array}{l}\text { LOADS } \\
\text { (T/OAY) }\end{array}$ & $\begin{array}{l}\text { MEAN } \\
\text { CONCEN- } \\
\text { TRATION } \\
\text { (MG/L) }\end{array}$ & $\begin{array}{l}\text { LOADS } \\
\text { (T/DAY) }\end{array}$ \\
\hline & \multicolumn{2}{|c|}{ DCTOHER } & \multicolumn{2}{|c|}{ NUVFMAFR } & \multicolumn{2}{|c|}{ DECEMBER } & \multicolumn{2}{|c|}{ JaINUARY } & \multicolumn{2}{|c|}{ FEBPUARY } & \multicolumn{2}{|c|}{ MARCH } \\
\hline $\begin{array}{l}1 \\
2 \\
3 \\
4 \\
5\end{array}$ & $\begin{array}{l}3 n \\
3 n \\
29 \\
29 \\
28\end{array}$ & $\begin{array}{l}.16 \\
.15 \\
.13 \\
.13 \\
.14\end{array}$ & $\begin{array}{r}62 \\
75 \\
92 \\
113 \\
138\end{array}$ & $\begin{array}{l}.33 \\
.56 \\
.57 \\
.64 \\
.74\end{array}$ & $\begin{array}{l}17 \\
19 \\
19 \\
19 \\
70\end{array}$ & $\begin{array}{l}.18 \\
.08 \\
.09 \\
.08 \\
.09\end{array}$ & $\begin{array}{l}23 \\
21 \\
20 \\
18 \\
17\end{array}$ & $\begin{array}{l}.11 \\
.110 \\
.10 \\
.09 \\
.08\end{array}$ & $\begin{array}{l}18 \\
19 \\
20 \\
22 \\
23\end{array}$ & $\begin{array}{l}.07 \\
.08 \\
.08 \\
.09 \\
.09\end{array}$ & $\begin{array}{r}5 \\
9 \\
16 \\
24 \\
35\end{array}$ & $\begin{array}{l}.02 \\
.04 \\
.07 \\
.10 \\
.15\end{array}$ \\
\hline $\begin{array}{r}6 \\
7 \\
8 \\
9 \\
10\end{array}$ & $\begin{array}{l}28 \\
28 \\
75 \\
40 \\
38\end{array}$ & $\begin{array}{l}.13 \\
.13 \\
.53 \\
.25 \\
.23\end{array}$ & $\begin{array}{l}168 \\
196 \\
191 \\
182 \\
113\end{array}$ & $\begin{array}{l}.95 \\
1.1 \\
1.1 \\
1.1 \\
1.0\end{array}$ & $\begin{array}{l}21 \\
22 \\
23 \\
24 \\
25\end{array}$ & $\begin{array}{l}.199 \\
010 \\
111 \\
.12 \\
.13\end{array}$ & $\begin{array}{l}16 \\
15 \\
14 \\
13 \\
12\end{array}$ & $\begin{array}{l}.07 \\
.07 \\
.06 \\
.06\end{array}$ & $\begin{array}{l}25 \\
26 \\
25 \\
22 \\
19\end{array}$ & $\begin{array}{r}.10 \\
.11 \\
.10 \\
.09 \\
.08\end{array}$ & $\begin{array}{r}52 \\
76 \\
88 \\
28 \\
8\end{array}$ & $\begin{array}{l}.21 \\
.31 \\
.36 \\
.12 \\
.04\end{array}$ \\
\hline $\begin{array}{l}11 \\
12 \\
13 \\
14 \\
15\end{array}$ & $\begin{array}{l}36 \\
34 \\
32 \\
30 \\
30\end{array}$ & $\begin{array}{l}.21 \\
.19 \\
.17 \\
.15 \\
.15\end{array}$ & $\begin{array}{l}165 \\
157 \\
150 \\
143 \\
134\end{array}$ & $\begin{array}{l}.89 \\
.81 \\
.73 \\
.73 \\
.69\end{array}$ & $\begin{array}{l}26 \\
27 \\
27 \\
23 \\
27\end{array}$ & $\begin{array}{r}.13 \\
.15 \\
.14 \\
.12 \\
.14\end{array}$ & $\begin{array}{l}11 \\
11 \\
12 \\
12 \\
13\end{array}$ & $\begin{array}{l}.05 \\
.05 \\
.05 \\
.05 \\
.06\end{array}$ & $\begin{array}{l}17 \\
16 \\
14 \\
12 \\
13\end{array}$ & $\begin{array}{l}.07 \\
.07 \\
.06 \\
.05 \\
.06\end{array}$ & $\begin{array}{r}8 \\
9 \\
10 \\
11 \\
12\end{array}$ & $\begin{array}{l}.03 \\
.04 \\
.04 \\
.05 \\
.05\end{array}$ \\
\hline $\begin{array}{l}16 \\
17 \\
18 \\
19 \\
20\end{array}$ & $\begin{array}{l}30 \\
30 \\
30 \\
30 \\
30\end{array}$ & $\begin{array}{l}.15 \\
.15 \\
.15 \\
.15 \\
.15\end{array}$ & $\begin{array}{r}102 \\
72 \\
51 \\
36 \\
25\end{array}$ & $\begin{array}{l}.52 \\
.37 \\
.25 \\
.17 \\
.12\end{array}$ & $\begin{array}{l}33 \\
40 \\
49 \\
58 \\
56\end{array}$ & $\begin{array}{l}.17 \\
.21 \\
.25 \\
.30 \\
.27\end{array}$ & $\begin{array}{l}13 \\
13 \\
14 \\
14 \\
13\end{array}$ & $\begin{array}{l}.06 \\
.06 \\
.06 \\
.06 \\
.06\end{array}$ & $\begin{array}{l}14 \\
15 \\
15 \\
17 \\
18\end{array}$ & $\begin{array}{l}.06 \\
.06 \\
.06 \\
.07 \\
.07\end{array}$ & $\begin{array}{r}11 \\
11 \\
10 \\
72 \\
157\end{array}$ & $\begin{array}{l}.05 \\
.05 \\
.05 \\
1.1 \\
4.4\end{array}$ \\
\hline $\begin{array}{l}21 \\
22 \\
23 \\
24 \\
25\end{array}$ & $\begin{array}{l}25 \\
25 \\
25 \\
25 \\
25\end{array}$ & $\begin{array}{l}112 \\
011 \\
.11 \\
.12 \\
.13\end{array}$ & $\begin{array}{l}18 \\
13 \\
12 \\
13 \\
13\end{array}$ & $\begin{array}{l}.09 \\
.06 \\
.05 \\
.05 \\
.05\end{array}$ & $\begin{array}{l}52 \\
48 \\
45 \\
41 \\
39\end{array}$ & $\begin{array}{l}.25 \\
.23 \\
.21 \\
.19 \\
.18\end{array}$ & $\begin{array}{l}13 \\
13 \\
13 \\
12 \\
12\end{array}$ & $\begin{array}{l}.06 \\
.06 \\
.06 \\
.06 \\
.06\end{array}$ & $\begin{array}{l}19 \\
19 \\
15 \\
11 \\
8\end{array}$ & $\begin{array}{l}.08 \\
.08 \\
.06 \\
.04 \\
.03\end{array}$ & $\begin{array}{r}415 \\
253 \\
125 \\
76 \\
41\end{array}$ & $\begin{array}{l}32 \\
12 \\
2.5 \\
.96 \\
.40\end{array}$ \\
\hline $\begin{array}{l}26 \\
27 \\
28 \\
29 \\
30 \\
31\end{array}$ & $\begin{array}{l}23 \\
23 \\
28 \\
34 \\
41 \\
51\end{array}$ & $\begin{array}{l}.22 \\
.14 \\
.13 \\
.15 \\
.18 \\
.24\end{array}$ & $\begin{array}{l}14 \\
15 \\
15 \\
16 \\
17 \\
--\end{array}$ & $\begin{array}{l}.06 \\
.06 \\
.06 \\
.07 \\
.08 \\
-.\end{array}$ & $\begin{array}{l}36 \\
33 \\
31 \\
29 \\
27 \\
25\end{array}$ & $\begin{array}{l}.17 \\
.15 \\
: 14 \\
.13 \\
.13 \\
.12\end{array}$ & $\begin{array}{l}13 \\
13 \\
14 \\
15 \\
15 \\
16\end{array}$ & $\begin{array}{l}.06 \\
.06 \\
.06 \\
.06 \\
.06 \\
.07\end{array}$ & \begin{tabular}{r}
6 \\
4 \\
3 \\
\hdashline- \\
--
\end{tabular} & $\begin{array}{l}.02 \\
.02 \\
.01 \\
-0 . \\
-\because- \\
--\end{array}$ & $\begin{array}{l}28 \\
26 \\
29 \\
28 \\
28 \\
27\end{array}$ & $\begin{array}{l}.25 \\
.26 \\
.29 \\
.27 \\
.25 \\
.26\end{array}$ \\
\hline TOTAL & -- & 5.25 & -- & 14.00 & $\cdots$ & 4.75 & -- & 2.02 & -- & 1.96 & -- & 56.72 \\
\hline
\end{tabular}

SUSPENDEO-SEOIMENT, WATER YEAR OCTOBER 1977 TO SEPTEMBER 1978

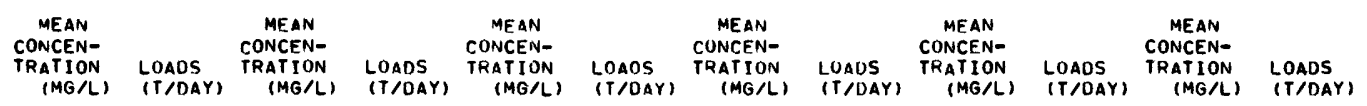

DAY

APRIL

MaY

JUNF

JULY

SEPTEMBER

$\begin{array}{lll}26 & .24 & 11 \\ 48 & .48 & 14 \\ 45 & .43 & 17 \\ 35 & .33 & 16 \\ 35 & .33 & 14\end{array}$

.08
.11
.13
.12
.10

$\begin{array}{ll}47 & .54 \\ 51 & .54 \\ 56 & .58 \\ 61 & .61 \\ 55 & .53\end{array}$

$\begin{array}{rr}946 & 133 \\ 96 & 1.9 \\ 67 & .95 \\ 10 & .85 \\ 72 & .77\end{array}$

$\begin{array}{rrr} & 117 & 1.8 \\ .9 & 79 & 1.0 \\ .95 & 77 & .89 \\ .85 & 74 & .80\end{array}$

$\begin{array}{ll}.8 & 39 \\ .0 & 44 \\ .89 & 49 \\ .80 & 54 \\ .74 & 61\end{array}$

$\begin{array}{ll}39 & .27 \\ 4 & .31 \\ 9 & .34 \\ 94 & .37\end{array}$

$\begin{array}{rrr}215 & 9.0 & 12 \\ 56 & 1.0 & 12 \\ 47 & .65 & 12 \\ 46 & .54 & 12\end{array}$

.09
.08
.10
.09
.08

$\begin{array}{ll}49 & .47 \\ 45 & .44 \\ 41 & .40 \\ 38 & .34\end{array}$

$554 \quad 187$

$\begin{array}{rc}188 & 8.1 \\ 64 & 1.2 \\ 59 & .98\end{array}$

$\begin{array}{ll}70 & .70 \\ 68 & .67 \\ 66 & .64\end{array}$

.70
.67
.64
.61
.58

68
76
77
75
74

.45

$\begin{array}{lll}64 & 1.3 & 12 \\ 28 & .38 & 12\end{array}$

11
12
13
14
15

$\begin{array}{ll}28 & .38 \\ 25 & .28 \\ 21 & .21 \\ 18 & .16 \\ 15 & .12\end{array}$

$\begin{array}{rc}12 & .08 \\ 29 & .06 \\ 1290 & 185^{\circ 4} \\ 278 & 23 \\ 117 & 4.9\end{array}$

$\begin{array}{ll}32 & .27 \\ 32 & .25 \\ 31 & .24 \\ 31 & .24\end{array}$

$\begin{array}{lc}53 & .63 \\ 70 & 1.2 \\ 68 & .92 \\ 60 & .65\end{array}$

$\begin{array}{ll}61 & .56 \\ 59 & .53 \\ 57 & .50 \\ 56 & .47\end{array}$

.56
.53
.50
.47
.49

72
71
109
105
55

.44
.52
1.9
1.7

$\begin{array}{ll}14 & .11 \\ 15 & .12 \\ 52 & .98 \\ 35 & .43 \\ 24 & .26\end{array}$

106
83
71
63
55

$\begin{array}{rrr}3.4 & 784 & 33 \\ 2.3 & 2060 & 643\end{array}$

$\begin{array}{rrr}2.3 & 2060 & 643 \\ 1.6 & 209 & 5.1 \\ 1.3 & 81 & 1.3\end{array}$

$\begin{array}{ll}47 & .49 \\ 42 & .42 \\ 33 & .33 \\ 13 & .13\end{array}$

53
51
61
92
67

.58
.47

.58
.47
.65

.65
1.3
.62

50
63
350
90
246

.39

$\begin{array}{lll}17 & .18 & 5 \\ 12 & .12 & 53 \\ 11 & .12 & 53 \\ 11 & .11 & 52\end{array}$

.94
.87
.87
.82
.74

65
61
57
53
1690

.72
.58
.53
.47

$\begin{array}{rr}200 & 12 \\ 92 & 3.8 \\ 78 & 2.3 \\ 82 & 1.8\end{array}$

60
55
50
45

.51

.48
.41
.36

81
53
44
40

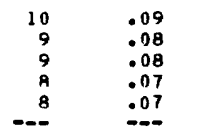

51
177
256
64
52
49

.70
4.1
5.2
.91
.70
.59

310

4.6
1.0
.81
.69
0.1

$\begin{array}{rr}123 & 4.4 \\ 59 & 1.1 \\ 57 & .88 \\ 54 & .81 \\ 52 & .73\end{array}$

43
41
197
113
38

.33
9.41

9.3

.31

-.. 987.75

$-.-\quad 29.11$

TOTAL LOAD FOR YEAR: 2179.00 TONS. 
Table 12. Suspended-sediment discharges for Steiner Branch, 1978 and 1979 water years.

\begin{tabular}{|c|c|c|c|c|c|c|c|c|c|c|c|c|}
\hline \multirow[t]{2}{*}{ DAY } & $\begin{array}{c}\text { MEAN } \\
\text { CONCEN- } \\
\text { TRATION } \\
(M G /)\end{array}$ & $\begin{array}{l}\text { LOAOS } \\
\text { (T/DAY) }\end{array}$ & $\begin{array}{l}\text { MEAV } \\
\text { PONCEIV- } \\
\text { TRATION } \\
\text { (MG/L) }\end{array}$ & $\begin{array}{l}\text { LOADS } \\
\text { (T/DAY) }\end{array}$ & $\begin{array}{l}\text { MEAN } \\
\text { CONCEN- } \\
\text { TRATION } \\
\text { (MG/L) }\end{array}$ & $\begin{array}{l}\text { LOADS } \\
\text { (T/OAY) }\end{array}$ & $\begin{array}{l}\text { MEAN } \\
\text { CONCEN- } \\
\text { THATION } \\
\text { (MG/L) }\end{array}$ & $\begin{array}{l}\text { LOAOS } \\
\text { (T/OAY })\end{array}$ & $\begin{array}{l}\text { MEAN } \\
\text { CONCEN- } \\
\text { TRATION } \\
\text { (MG/L) }\end{array}$ & $\begin{array}{l}\text { LOAUS } \\
\text { (T/DAY) }\end{array}$ & $\begin{array}{l}\text { MEAN } \\
\text { CONCEN- } \\
\text { TRATION } \\
\text { (MG/L) }\end{array}$ & $\begin{array}{l}\text { LOAOS } \\
\text { (T/DAY) }\end{array}$ \\
\hline & \multicolumn{2}{|c|}{ OCTOBFR } & \multicolumn{2}{|c|}{ NOVEMAER } & \multicolumn{2}{|c|}{ DECEMAER } & \multicolumn{2}{|c|}{ JANUARY } & \multicolumn{2}{|c|}{ FEBRUARY } & \multicolumn{2}{|c|}{ MARCH } \\
\hline $\begin{array}{l}1 \\
2 \\
3 \\
4 \\
5\end{array}$ & $\begin{array}{l}27 \\
30 \\
35 \\
40 \\
45\end{array}$ & $\begin{array}{l}.18 \\
.22 \\
.29 \\
.29 \\
.40\end{array}$ & $\begin{array}{l}7 \\
\text { A } \\
\text { A } \\
8 \\
\text { A }\end{array}$ & $\begin{array}{l}.05 \\
.06 \\
.06 \\
.06 \\
.06\end{array}$ & $\begin{array}{l}5 \\
4 \\
5 \\
6 \\
7\end{array}$ & $\begin{array}{l}.05 \\
.03 \\
.05 \\
.06 \\
.07\end{array}$ & $\begin{array}{l}13 \\
13 \\
13 \\
14 \\
14\end{array}$ & $\begin{array}{l}.09 \\
.09 \\
.09 \\
.09 \\
.09\end{array}$ & $\begin{array}{l}38 \\
39 \\
39 \\
40 \\
40\end{array}$ & $\begin{array}{l}.26 \\
.25 \\
.24 \\
.26 \\
.26\end{array}$ & $\begin{array}{l}10 \\
10 \\
15 \\
23 \\
27\end{array}$ & $\begin{array}{l}.08 \\
.08 \\
.13 \\
.23 \\
.26\end{array}$ \\
\hline $\begin{array}{r}6 \\
7 \\
8 \\
9 \\
10\end{array}$ & $\begin{array}{l}51 \\
55 \\
58 \\
61 \\
55\end{array}$ & $\begin{array}{l}.41 \\
.41 \\
.43 \\
.63 \\
.63\end{array}$ & $\begin{array}{l}9 \\
9 \\
9 \\
9 \\
9\end{array}$ & $\begin{array}{l}.07 \\
.07 \\
.07 \\
.07 \\
.07\end{array}$ & $\begin{array}{r}9 \\
12 \\
15 \\
19 \\
-\end{array}$ & $\begin{array}{l}.08 \\
.11 \\
.13 \\
.15 \\
.14\end{array}$ & $\begin{array}{r}14 \\
14 \\
\hdashline-2 \\
\hdashline-\end{array}$ & $\begin{array}{l}.09 \\
.09 \\
.09 \\
.10 \\
.10\end{array}$ & $\begin{array}{l}40 \\
41 \\
41 \\
42 \\
42\end{array}$ & $\begin{array}{l}.26 \\
.28 \\
.27 \\
.27 \\
.27\end{array}$ & $\begin{array}{l}29 \\
31 \\
34 \\
37 \\
39\end{array}$ & $\begin{array}{l}.28 \\
.30 \\
.31 \\
.33 \\
.34\end{array}$ \\
\hline $\begin{array}{l}11 \\
12 \\
13 \\
14 \\
15\end{array}$ & $\begin{array}{l}66 \\
39 \\
33 \\
31 \\
21\end{array}$ & $\begin{array}{l}.57 \\
.31 \\
.25 \\
.23 \\
.21\end{array}$ & $\begin{array}{l}10 \\
10 \\
83 \\
44 \\
39\end{array}$ & $\begin{array}{l}.07 \\
.07 \\
1.6 \\
.48 \\
.38\end{array}$ & $\begin{array}{l}-21 \\
17 \\
14 \\
11\end{array}$ & $\begin{array}{l}.17 \\
.18 \\
.14 \\
.12 \\
.10\end{array}$ & $\overline{-}$ & $\begin{array}{l}.10 \\
.12 \\
.13 \\
.14 \\
.14\end{array}$ & $\begin{array}{l}42 \\
43 \\
37 \\
29 \\
24\end{array}$ & $\begin{array}{l}.27 \\
.28 \\
.24 \\
.19 \\
.15\end{array}$ & $\begin{array}{l}42 \\
44 \\
45 \\
46 \\
47\end{array}$ & $\begin{array}{l}.37 \\
.42 \\
.47 \\
.51 \\
.51\end{array}$ \\
\hline $\begin{array}{l}16 \\
17 \\
18 \\
19 \\
20\end{array}$ & $\begin{array}{l}26 \\
24 \\
22 \\
20 \\
14\end{array}$ & $\begin{array}{l}.20 \\
.18 \\
.17 \\
.16 \\
.15\end{array}$ & $\begin{array}{r}33 \\
137 \\
57 \\
46 \\
42\end{array}$ & $\begin{array}{l}.31 \\
4.1 \\
.81 \\
.52 \\
.44\end{array}$ & $\begin{array}{r}9 \\
8 \\
7 \\
9 \\
11\end{array}$ & $\begin{array}{l}.08 \\
.06 \\
.06 \\
.07 \\
.09\end{array}$ & $\ddot{m}=$ & $\begin{array}{l}.14 \\
.16 \\
.17 \\
.19 \\
.20\end{array}$ & $\begin{array}{l}19 \\
15 \\
12 \\
12 \\
13\end{array}$ & $\begin{array}{l}.12 \\
.10 \\
.08 \\
.08 \\
.08\end{array}$ & $\begin{array}{r}48 \\
49 \\
277 \\
810 \\
330\end{array}$ & $\begin{array}{l}.51 \\
.52 \\
9.0 \\
68 \\
25\end{array}$ \\
\hline $\begin{array}{l}? 1 \\
? 2 \\
23 \\
24 \\
25\end{array}$ & $\begin{array}{l}16 \\
14 \\
12 \\
10 \\
9\end{array}$ & $\begin{array}{l}.13 \\
.11 \\
.10 \\
.08 \\
.08\end{array}$ & $\begin{array}{l}39 \\
36 \\
33 \\
30 \\
25\end{array}$ & $\begin{array}{r}.38 \\
.34 \\
.34 \\
.30 \\
.23\end{array}$ & $\begin{array}{l}13 \\
16 \\
19 \\
23 \\
23\end{array}$ & $\begin{array}{l}111 \\
112 \\
.15 \\
118 \\
.17\end{array}$ & $\begin{array}{l}26 \\
24 \\
20 \\
17 \\
15\end{array}$ & $\begin{array}{l}.21 \\
.19 \\
.16 \\
.13 \\
.11\end{array}$ & $\begin{array}{l}13 \\
13 \\
14 \\
14 \\
15\end{array}$ & $\begin{array}{r}.09 \\
.09 \\
.12 \\
.11 \\
.12\end{array}$ & $\begin{array}{l}227 \\
298 \\
418 \\
223 \\
114\end{array}$ & $\begin{array}{c}13 \\
24 \\
43 \\
18 \\
5.7\end{array}$ \\
\hline $\begin{array}{l}26 \\
27 \\
28 \\
29 \\
30 \\
31\end{array}$ & $\begin{array}{l}7 \\
6 \\
6 \\
6 \\
7 \\
7\end{array}$ & $\begin{array}{l}.07 \\
.06 \\
.05 \\
.05 \\
.06 \\
.06\end{array}$ & $\begin{array}{r}19 \\
15 \\
11 \\
9 \\
7 \\
-9\end{array}$ & $\begin{array}{r}.18 \\
.13 \\
.10 \\
.08 \\
.06 \\
\end{array}$ & $\begin{array}{l}21 \\
19 \\
16 \\
15 \\
13 \\
13\end{array}$ & $\begin{array}{l}.16 \\
.14 \\
.12 \\
.11 \\
.09 \\
.10\end{array}$ & $\begin{array}{l}13 \\
11 \\
10 \\
14 \\
23 \\
36\end{array}$ & $\begin{array}{l}.10 \\
.08 \\
.06 \\
.09 \\
.16 \\
.23\end{array}$ & $\begin{array}{r}15 \\
13 \\
12 \\
-0- \\
-0 .\end{array}$ & $\begin{array}{l}.11 \\
.10 \\
.09 \\
0-- \\
-\infty-\end{array}$ & $\begin{array}{r}105 \\
96 \\
87 \\
242 \\
179 \\
150\end{array}$ & $\begin{array}{c}4.0 \\
3.2 \\
2.9 \\
15 \\
11 \\
6.9\end{array}$ \\
\hline IOTAL & -- & 7.16 & -- & 11.56 & $-\infty$ & 3.39 & $-\infty$ & 3.93 & $-\infty$ & 5.04 & $m$ & $254 \cdot 35$ \\
\hline
\end{tabular}

SUSPENDED-SEDIMENT, WATER YEAR OCTOBER 1978 TO SEPTEMBER 1979

\begin{tabular}{|c|c|c|c|c|c|c|c|c|c|c|c|c|}
\hline \multirow[t]{2}{*}{ DAY } & $\begin{array}{l}\text { MEAN } \\
\text { CONCEN- } \\
\text { TRATION } \\
\text { (MG LL) }\end{array}$ & $\begin{array}{l}\text { LOAOS } \\
\text { (T/DAY) }\end{array}$ & $\begin{array}{l}\text { MEAN } \\
\text { CONCEN- } \\
\text { TRATION } \\
\text { (MG/L) }\end{array}$ & $\begin{array}{l}\text { LDADS } \\
\text { (T/DAY) }\end{array}$ & $\begin{array}{l}\text { MEAN } \\
\text { CONCEN- } \\
\text { TRAIION } \\
\text { (MG LL) }\end{array}$ & $\begin{array}{l}\text { LOADS } \\
\text { (T/DAY) }\end{array}$ & $\begin{array}{l}\text { MEAN } \\
\text { CUNCEN- } \\
\text { TRATION } \\
\text { (MG LL) }\end{array}$ & $\begin{array}{l}\text { LOADS } \\
\text { (T/OAY) }\end{array}$ & $\begin{array}{l}\text { MEAN } \\
\text { CONCEN- } \\
\text { TRATION } \\
\text { (MG/L) }\end{array}$ & $\begin{array}{l}\text { LOAOS } \\
\text { (TIDAY) }\end{array}$ & $\begin{array}{l}\text { MEAN } \\
\text { CONCEN- } \\
\text { TRATION } \\
\text { (MG/L) }\end{array}$ & $\begin{array}{l}\text { LOADS } \\
\text { (T/DAY) }\end{array}$ \\
\hline & \multicolumn{2}{|c|}{ APRIL } & \multicolumn{2}{|r|}{ MAY } & \multicolumn{2}{|c|}{ JUNE } & \multicolumn{2}{|c|}{ JULY } & \multicolumn{2}{|c|}{ AUGUST } & \multicolumn{2}{|c|}{ SEPTEMBER } \\
\hline $\begin{array}{l}1 \\
2 \\
3 \\
4 \\
5\end{array}$ & $\begin{array}{r}118 \\
74 \\
43 \\
26 \\
16\end{array}$ & $\begin{array}{l}4.5 \\
2.9 \\
1.5 \\
.79 \\
.48\end{array}$ & $\begin{array}{l}22 \\
40 \\
76 \\
57 \\
48\end{array}$ & $\begin{array}{l}.09 \\
1.0 \\
2.0 \\
1.3 \\
1.1\end{array}$ & $\begin{array}{l}64 \\
63 \\
63 \\
62 \\
62\end{array}$ & $\begin{array}{l}.85 \\
.81 \\
.79 \\
.79 \\
.79\end{array}$ & $\begin{array}{l}32 \\
32 \\
32 \\
32 \\
32\end{array}$ & $\begin{array}{l}.36 \\
.35 \\
.35 \\
.38 \\
.31\end{array}$ & $\begin{array}{r}53 \\
49 \\
46 \\
43 \\
354\end{array}$ & $\begin{array}{r}.44 \\
.41 \\
.49 \\
28\end{array}$ & $\begin{array}{l}20 \\
19 \\
19 \\
19 \\
19\end{array}$ & $\begin{array}{l}.22 \\
.21 \\
.20 \\
.23 \\
.19\end{array}$ \\
\hline $\begin{array}{r}6 \\
7 \\
8 \\
9 \\
10\end{array}$ & $\begin{array}{l}18 \\
24 \\
32 \\
43 \\
56\end{array}$ & $\begin{array}{l}.58 \\
.62 \\
.84 \\
1.1 \\
1.3\end{array}$ & $\begin{array}{l}41 \\
40 \\
41 \\
42 \\
43\end{array}$ & $\begin{array}{l}.91 \\
.87 \\
.86 \\
.84 \\
.81\end{array}$ & $\begin{array}{l}61 \\
58 \\
55 \\
52 \\
60\end{array}$ & $\begin{array}{l}.75 \\
.72 \\
.68 \\
.64 \\
.89\end{array}$ & $\begin{array}{l}32 \\
33 \\
33 \\
33 \\
33\end{array}$ & $\begin{array}{l}.29 \\
.30 \\
.30 \\
.29 \\
.29\end{array}$ & $\begin{array}{r}93 \\
96 \\
183 \\
186\end{array}$ & $\begin{array}{l}1.1 \\
1.72 \\
35 \\
11\end{array}$ & $\begin{array}{l}19 \\
19 \\
18 \\
18 \\
18\end{array}$ & $\begin{array}{l}.19 \\
.19 \\
.18 \\
.18 \\
.18\end{array}$ \\
\hline $\begin{array}{l}11 \\
12 \\
13 \\
14 \\
15\end{array}$ & $\begin{array}{r}5 A \\
55 \\
-\square \\
-- \\
---\end{array}$ & $\begin{array}{l}1.4 \\
1.4 \\
1.3 \\
1.2 \\
1.1\end{array}$ & $\begin{array}{l}45 \\
46 \\
47 \\
49 \\
47\end{array}$ & $\begin{array}{l}.84 \\
.81 \\
.81 \\
.81 \\
.75\end{array}$ & $\begin{array}{l}36 \\
29 \\
29 \\
29 \\
29\end{array}$ & $\begin{array}{l}.46 \\
.34 \\
.34 \\
.33 \\
.33\end{array}$ & $\begin{array}{r}33 \\
34 \\
15 \\
294 \\
87\end{array}$ & $\begin{array}{r}.29 \\
.30 \\
11.34 \\
.89\end{array}$ & $\begin{array}{l}66 \\
60 \\
55 \\
55 \\
54\end{array}$ & $\begin{array}{l}.96 \\
.74 \\
.65 \\
.63 \\
.57\end{array}$ & $\begin{array}{l}18 \\
18 \\
19 \\
19 \\
19\end{array}$ & $\begin{array}{l}.17 \\
.17 \\
.17 \\
.16 \\
.16\end{array}$ \\
\hline $\begin{array}{l}16 \\
17 \\
18 \\
19 \\
20\end{array}$ & 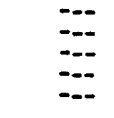 & $\begin{array}{l}.99 \\
.92 \\
.94 \\
.80 \\
.78\end{array}$ & $\begin{array}{l}45 \\
43 \\
42 \\
83 \\
84\end{array}$ & $\begin{array}{r}.69 \\
.66 \\
.67 \\
1.6 \\
1.3\end{array}$ & $\begin{array}{l}30 \\
30 \\
30 \\
30 \\
30\end{array}$ & $\begin{array}{l}.33 \\
.33 \\
.33 \\
.33 \\
.38\end{array}$ & $\begin{array}{l}67 \\
60 \\
58 \\
55 \\
53\end{array}$ & $\begin{array}{l}.62 \\
.54 \\
.50 \\
.47 \\
.44\end{array}$ & $\begin{array}{r}52 \\
107 \\
179 \\
45 \\
140\end{array}$ & $\begin{array}{l}.53 \\
5.0 \\
9.5 \\
.67 \\
4.7\end{array}$ & $\begin{array}{l}19 \\
19 \\
20 \\
20 \\
20\end{array}$ & $\begin{array}{l}.16 \\
.16 \\
.17 \\
.16 \\
.17\end{array}$ \\
\hline $\begin{array}{l}21 \\
22 \\
23 \\
24 \\
25\end{array}$ & $\begin{array}{l}=- \\
=-- \\
=-\infty\end{array}$ & $\begin{array}{l}.72 \\
.64 \\
.59 \\
.55 \\
.66\end{array}$ & $\begin{array}{l}80 \\
78 \\
76 \\
74 \\
72\end{array}$ & $\begin{array}{l}1.2 \\
1.1 \\
1.1 \\
1.1 \\
1.0\end{array}$ & $\begin{array}{l}30 \\
30 \\
31 \\
31 \\
31\end{array}$ & $\begin{array}{l}.34 \\
.33 \\
.33 \\
.33 \\
.32\end{array}$ & $\begin{array}{l}51 \\
56 \\
47 \\
44 \\
41\end{array}$ & $\begin{array}{l}.43 \\
.58 \\
.41 \\
.40 \\
.40\end{array}$ & $\begin{array}{l}61 \\
68 \\
46 \\
39 \\
33\end{array}$ & $\begin{array}{l}1.0 \\
1.2 \\
.67 \\
.53 \\
.42\end{array}$ & $\begin{array}{l}21 \\
21 \\
22 \\
22 \\
22\end{array}$ & $\begin{array}{l}.17 \\
.16 \\
.18 \\
.18 \\
.18\end{array}$ \\
\hline $\begin{array}{l}26 \\
27 \\
28 \\
29 \\
30 \\
31\end{array}$ & 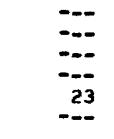 & $\begin{array}{l}.86 \\
.70 \\
.58 \\
.49 \\
.46 \\
-.-5\end{array}$ & $\begin{array}{l}70 \\
68 \\
66 \\
66 \\
65 \\
64\end{array}$ & $\begin{array}{l}1.0 \\
.99 \\
.93 \\
.89 \\
.87 \\
.87\end{array}$ & $\begin{array}{r}31 \\
31 \\
31 \\
31 \\
32 \\
-\end{array}$ & $\begin{array}{r}.32 \\
.32 \\
.33 \\
.36 \\
.36 \\
-.--\end{array}$ & $\begin{array}{l}38 \\
36 \\
34 \\
32 \\
68 \\
57\end{array}$ & $\begin{array}{r}.34 \\
.64 \\
.28 \\
.26 \\
.93 \\
.51\end{array}$ & $\begin{array}{l}28 \\
23 \\
20 \\
33 \\
20 \\
20\end{array}$ & $\begin{array}{l}.34 \\
.33 \\
.26 \\
.48 \\
.24 \\
.23\end{array}$ & $\begin{array}{r}23 \\
23 \\
24 \\
24 \\
25 \\
---\end{array}$ & $\begin{array}{l}.17 \\
.17 \\
.17 \\
.18 \\
.17 \\
0.0\end{array}$ \\
\hline TOTAL & $m-$ & 31.59 & $-\infty$ & 30.07 & $-\infty$ & 14.55 & $\cdots$ & 23.79 & $\cdots$ & 108.65 & $\infty$ & 5.35 \\
\hline
\end{tabular}

TOTAL LOAN FOR YEAR: 499.43 TONS. 
Table 13. Suspended sediment discharges for Yellowstone River, 1978 and 1979 water years.

\begin{tabular}{|c|c|c|c|c|c|c|c|c|c|c|c|c|}
\hline \multirow[t]{2}{*}{ DaY } & $\begin{array}{l}\text { MEAN } \\
\text { CONCEN- } \\
\text { TRATION } \\
\text { (MG/L) }\end{array}$ & $\begin{array}{l}\text { LOADS } \\
\text { (T/DAY }\end{array}$ & $\begin{array}{l}\text { MEAN } \\
\text { CONCEN- } \\
\text { TRATION } \\
\text { (MG/L) }\end{array}$ & $\begin{array}{l}\text { LOADS } \\
\text { (T/OAY) }\end{array}$ & $\begin{array}{l}\text { MEAN } \\
\text { CONCEN- } \\
\text { TRAIION } \\
\text { (MGAL) }\end{array}$ & $\begin{array}{l}\text { LOADS } \\
\text { (T/DAY) }\end{array}$ & $\begin{array}{l}\text { MEAN } \\
\text { CONCEN- } \\
\text { TRATION } \\
\text { (MG/L) }\end{array}$ & $\begin{array}{l}\text { LOADS } \\
\text { (T/DAY) }\end{array}$ & $\begin{array}{l}\text { MEAN } \\
\text { CONCEN- } \\
\text { TRATION } \\
\text { IMG/L) }\end{array}$ & $\begin{array}{l}\text { LOAOS } \\
\text { (TIUAY) }\end{array}$ & $\begin{array}{l}\text { MEAN } \\
\text { CONCEN- } \\
\text { TRATION } \\
\text { (MG/L) }\end{array}$ & $\begin{array}{l}\text { LOADS } \\
\text { TT } / D A Y .\end{array}$ \\
\hline & \multicolumn{2}{|c|}{ OCTOBER } & \multicolumn{2}{|c|}{ NOVEMBER } & \multicolumn{2}{|c|}{ DECEMRER } & \multicolumn{2}{|c|}{ JANUARY } & \multicolumn{2}{|c|}{ FEBRUARY } & \multicolumn{2}{|c|}{ MARCH } \\
\hline $\begin{array}{l}1 \\
2 \\
3 \\
4 \\
5\end{array}$ & & $\begin{array}{l}.22 \\
.19 \\
116 \\
.15 \\
.17\end{array}$ & & $\begin{array}{l}.24 \\
.50 \\
.34 \\
.28 \\
.24\end{array}$ & $\begin{array}{r}9 \\
10 \\
10 \\
11\end{array}$ & $\begin{array}{l}.17 \\
.116 \\
.17 \\
.17 \\
.18\end{array}$ & $\begin{array}{l}71 \\
72 \\
72 \\
72 \\
72\end{array}$ & $\begin{array}{l}1.2 \\
1.2 \\
1.2 \\
1.2 \\
1.2\end{array}$ & $\begin{array}{l}35 \\
35 \\
35 \\
34 \\
33\end{array}$ & $\begin{array}{l}.53 \\
.53 \\
.53 \\
.51 \\
.50\end{array}$ & $\begin{array}{r}14 \\
6 \\
2 \\
2 \\
2\end{array}$ & $\begin{array}{l}.19 \\
.08 \\
.03 \\
.03 \\
.03\end{array}$ \\
\hline $\begin{array}{r}6 \\
7 \\
8 \\
9 \\
10\end{array}$ & & $\begin{array}{l}.15 \\
.14 \\
.42 \\
.34 \\
.29\end{array}$ & & $\begin{array}{l}.26 \\
.26 \\
.26 \\
.29 \\
.28\end{array}$ & $\begin{array}{l}12 \\
12 \\
13 \\
14 \\
15\end{array}$ & $\begin{array}{l}.19 \\
.20 \\
.22 \\
.25 \\
.28\end{array}$ & $\begin{array}{l}73 \\
73 \\
73 \\
73 \\
74\end{array}$ & $\begin{array}{l}1.2 \\
1.2 \\
1.2 \\
1.1 \\
1.2\end{array}$ & $\begin{array}{l}33 \\
32 \\
29 \\
26 \\
23\end{array}$ & $\begin{array}{l}.50 \\
.48 \\
.44 \\
.38 \\
.34\end{array}$ & $\begin{array}{l}1 \\
1 \\
1 \\
2 \\
4\end{array}$ & $\begin{array}{l}.02 \\
.02 \\
.02 \\
.03 \\
.06\end{array}$ \\
\hline $\begin{array}{l}11 \\
12 \\
13 \\
14 \\
15\end{array}$ & & $\begin{array}{l}.29 \\
.28 \\
.24 \\
.21 \\
.19\end{array}$ & & $\begin{array}{l}.23 \\
.21 \\
.20 \\
.21 \\
.21\end{array}$ & $\begin{array}{l}16 \\
17 \\
18 \\
20 \\
25\end{array}$ & $\begin{array}{r}.30 \\
.32 \\
.33 \\
.36 \\
.44\end{array}$ & $\begin{array}{l}73 \\
64 \\
54 \\
47 \\
40\end{array}$ & $\begin{array}{l}1.1 \\
1.0 \\
.85 \\
.74 \\
.65\end{array}$ & $\begin{array}{l}20 \\
18 \\
16 \\
14 \\
16\end{array}$ & $\begin{array}{l}.29 \\
.26 \\
.23 \\
.20 \\
.22\end{array}$ & $\begin{array}{r}5 \\
6 \\
7 \\
9 \\
11\end{array}$ & $\begin{array}{l}.08 \\
.10 \\
.12 \\
.18 \\
.22\end{array}$ \\
\hline $\begin{array}{l}16 \\
17 \\
18 \\
19 \\
20\end{array}$ & & $\begin{array}{l}19 \\
.19 \\
119 \\
.18 \\
.16\end{array}$ & & $\begin{array}{l}.21 \\
.21 \\
.20 \\
.18 \\
.18\end{array}$ & $\begin{array}{l}33 \\
42 \\
54 \\
66 \\
68\end{array}$ & $\begin{array}{l}.59 \\
.75 \\
196 \\
1.2 \\
1.2\end{array}$ & $\begin{array}{l}34 \\
29 \\
25 \\
23 \\
21\end{array}$ & $\begin{array}{l}.55 \\
.49 \\
.42 \\
.39 \\
.35\end{array}$ & $\begin{array}{l}19 \\
23 \\
26 \\
31 \\
36\end{array}$ & $\begin{array}{l}.27 \\
.32 \\
.37 \\
.44 \\
.51\end{array}$ & $\begin{array}{l}11 \\
11 \\
11 \\
17 \\
93\end{array}$ & $\begin{array}{l}.23 \\
.23 \\
.24 \\
.75 \\
8.4\end{array}$ \\
\hline $\begin{array}{l}21 \\
22 \\
23 \\
24 \\
25\end{array}$ & & $\begin{array}{l}16 \\
.16 \\
.16 \\
.18 \\
.21\end{array}$ & & $\begin{array}{l}.17 \\
.15 \\
.14 \\
.13 \\
.13\end{array}$ & $\begin{array}{l}69 \\
69 \\
69 \\
69 \\
70\end{array}$ & $\begin{array}{l}1.2 \\
1.2 \\
1.2 \\
1.2 \\
1.2\end{array}$ & $\begin{array}{l}19 \\
17 \\
16 \\
14 \\
13\end{array}$ & $\begin{array}{l}.32 \\
.28 \\
.27 \\
.23 \\
.22\end{array}$ & $\begin{array}{l}42 \\
48 \\
46 \\
44 \\
41\end{array}$ & $\begin{array}{l}.59 \\
.67 \\
.65 \\
.62 \\
.58\end{array}$ & $\begin{array}{r}461 \\
285 \\
96 \\
38 \\
29\end{array}$ & $\begin{array}{c}136 \\
48 \\
10 \\
2.4 \\
1.4\end{array}$ \\
\hline $\begin{array}{l}26 \\
27 \\
28 \\
29 \\
30 \\
31\end{array}$ & & $\begin{array}{l}.19 \\
.16 \\
.15 \\
.14 \\
.13 \\
.18\end{array}$ & & $\begin{array}{l}.13 \\
.14 \\
.15 \\
.18 \\
.20\end{array}$ & $\begin{array}{l}70 \\
70 \\
70 \\
71 \\
71 \\
71\end{array}$ & $\begin{array}{l}1.2 \\
1.2 \\
1.2 \\
1.2 \\
1.2 \\
1.2\end{array}$ & $\begin{array}{l}15 \\
17 \\
19 \\
21 \\
24 \\
27\end{array}$ & $\begin{array}{l}.24 \\
.28 \\
.30 \\
.33 \\
.36 \\
.41\end{array}$ & $\begin{array}{r}39 \\
37 \\
32 \\
--- \\
---\end{array}$ & $\begin{array}{l}.53 \\
.50 \\
.43 \\
--. \\
-:- \\
-. .\end{array}$ & $\begin{array}{l}20 \\
23 \\
36 \\
32 \\
29 \\
27\end{array}$ & $\begin{array}{l}.90 \\
1.1 \\
1.8 \\
1.5 \\
1.3 \\
1.2\end{array}$ \\
\hline FotAL & & 6.17 & & 6.56 & --- & 21.64 & $\ldots$ & 21.68 & $\ldots$ & 12.42 & $\ldots$ & 216.66 \\
\hline
\end{tabular}

\begin{tabular}{|c|c|c|c|c|c|c|c|c|c|c|c|c|}
\hline \multirow[t]{2}{*}{ Dar } & 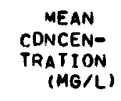 & $\begin{array}{l}\text { LOADS } \\
\text { (T/DAY })\end{array}$ & $\begin{array}{c}\text { MEAN } \\
\text { CONCAN- } \\
\text { TRATIIN } \\
\text { (MG }\end{array}$ & $\begin{array}{l}\text { LOADS } \\
\text { (T/DAYY }\end{array}$ & $\begin{array}{c}\text { MEAN } \\
\text { CONCAN- } \\
\text { TRATION } \\
\text { (MG }\end{array}$ & $\begin{array}{l}\text { LOADS } \\
\text { IT/OAYY }\end{array}$ & $\begin{array}{l}\text { MEAN } \\
\text { CONCEN- } \\
\text { THATION } \\
\text { IMG/L) }\end{array}$ & $\begin{array}{l}\text { LOAOS } \\
\text { (T/DAY }\end{array}$ & $\begin{array}{l}\text { MEAN } \\
\text { CONCEN- } \\
\text { TRATION } \\
\text { (MG/L) }\end{array}$ & $\begin{array}{l}\text { LOADS } \\
\text { (T/DAYY }\end{array}$ & $\begin{array}{l}\text { MEAN } \\
\text { CONCEN- } \\
\text { TRATION } \\
\text { (MG/L) }\end{array}$ & $\begin{array}{l}\text { LOADS } \\
\text { (T/DAYY }\end{array}$ \\
\hline & \multicolumn{2}{|r|}{ APRIL } & \multicolumn{2}{|r|}{ mar } & \multicolumn{2}{|c|}{ JUNE } & \multicolumn{2}{|c|}{ JULY } & \multicolumn{2}{|c|}{ AUGUST } & \multicolumn{2}{|c|}{ SEPTEMBER } \\
\hline $\begin{array}{l}1 \\
2 \\
3 \\
4 \\
5\end{array}$ & $\begin{array}{l}24 \\
22 \\
22 \\
22 \\
22\end{array}$ & $\begin{array}{l}1.1 \\
1.0 \\
.93 \\
.95 \\
.93\end{array}$ & $\begin{array}{l}12 \\
12 \\
12 \\
17 \\
26\end{array}$ & $\begin{array}{l}.33 \\
.31 \\
.31 \\
.45 \\
.69\end{array}$ & \begin{tabular}{l}
$\because$ \\
$\because \because$ \\
\hdashline$i$
\end{tabular} & $\begin{array}{l}2.3 \\
2.1 \\
1.8 \\
1.7 \\
1.7\end{array}$ & $\begin{array}{r}477 \\
120 \\
54 \\
42 \\
42\end{array}$ & $\begin{array}{r}147 \\
9.8 \\
3.5 \\
2.4 \\
2.1\end{array}$ & $\begin{array}{l}51 \\
38 \\
32 \\
30 \\
29\end{array}$ & $\begin{array}{l}2.5 \\
1.8 \\
1.4 \\
1.2 \\
1.2\end{array}$ & \begin{tabular}{l}
$\because-$ \\
$\because \because$ \\
$\because \because$ \\
\hdashline-
\end{tabular} & $\begin{array}{l}.70 \\
: 70 \\
: 54 \\
.54 \\
.54\end{array}$ \\
\hline $\begin{array}{r}6 \\
7 \\
8 \\
9 \\
10\end{array}$ & $\begin{array}{r}184 \\
30 \\
19 \\
28 \\
32\end{array}$ & $\begin{array}{c}25 \\
2.1 \\
101 \\
1.4 \\
2.4\end{array}$ & $\begin{array}{l}37 \\
34 \\
27 \\
22 \\
18\end{array}$ & $\begin{array}{l}.97 \\
.86 \\
.81 \\
.59 \\
.45\end{array}$ & $\begin{array}{l}57 \\
63 \\
70 \\
77 \\
86\end{array}$ & $\begin{array}{l}1.7 \\
1.9 \\
2.1 \\
2.1 \\
2.3\end{array}$ & $\begin{array}{r}109 \\
142 \\
83 \\
59 \\
52\end{array}$ & $\begin{array}{c}16 \\
12 \\
4.2 \\
3.0 \\
2.4\end{array}$ & $\begin{array}{l}29 \\
29 \\
28 \\
28 \\
28\end{array}$ & $\begin{array}{l}1: 1 \\
1: 1 \\
: 1 \\
1: 1 \\
1.1\end{array}$ & $\begin{array}{l}\because- \\
\because \because \\
\because-\end{array}$ & $\begin{array}{l}.52 \\
.50 \\
.46 \\
.46 \\
.44\end{array}$ \\
\hline $\begin{array}{l}11 \\
12 \\
13 \\
14 \\
15\end{array}$ & $\begin{array}{l}17 \\
19 \\
19 \\
20 \\
21\end{array}$ & $\begin{array}{c}1.0 \\
: 90 \\
: 83 \\
.79 \\
.77\end{array}$ & $\begin{array}{r}14 \\
18 \\
508 \\
132 \\
50\end{array}$ & $\begin{array}{c}.36 \\
145 \\
28 . \\
28 \\
6.5\end{array}$ & $\begin{array}{l}92 \\
90 \\
86 \\
82 \\
78\end{array}$ & $\begin{array}{l}2.4 \\
2.3 \\
2.3 \\
2.01 \\
2.1\end{array}$ & $\begin{array}{l}47 \\
50 \\
63 \\
55 \\
52\end{array}$ & $\begin{array}{l}2.0 \\
2.3 \\
3.1 \\
2.1 \\
2.2 \\
2.0\end{array}$ & $\begin{array}{l}28 \\
27 \\
27 \\
27 \\
26\end{array}$ & $\begin{array}{l}1.0 \\
1.00 \\
999 \\
.96 \\
996\end{array}$ & $\begin{array}{l}\because-- \\
\because \because- \\
\because \because\end{array}$ & $\begin{array}{l}.44 \\
.85 \\
2.7 \\
3.4 \\
1.0\end{array}$ \\
\hline $\begin{array}{l}16 \\
17 \\
18 \\
19 \\
20\end{array}$ & $\begin{array}{l}20 \\
19 \\
34 \\
16 \\
14\end{array}$ & $\begin{array}{r}.69 \\
.62 \\
2.2 \\
.77 \\
.60\end{array}$ & $\begin{array}{r}40 \\
29 \\
18 \\
33 \\
--\end{array}$ & $\begin{array}{l}4.0 \\
2.0 \\
1: 3 \\
2: 0 \\
1.0\end{array}$ & $\begin{array}{r}160 \\
2070 \\
261 \\
50 \\
40\end{array}$ & $\begin{array}{c}8.8 \\
7790 \\
32 \\
3.3 \\
2.2\end{array}$ & $\begin{array}{r}49 \\
46 \\
40 \\
22 \\
682\end{array}$ & $\begin{array}{r}2.0 \\
1.7 \\
1.5 \\
2140^{\circ 1}\end{array}$ & $\begin{array}{l}26 \\
26 \\
26 \\
37 \\
30\end{array}$ & $\begin{array}{l}1.0 \\
.993 \\
.97 \\
2.00 \\
1.1\end{array}$ & $\begin{array}{r}25 \\
35 \\
422 \\
62 \\
136\end{array}$ & $\begin{array}{c}: 81 \\
257 \cdot 3 \\
3.7 \\
18\end{array}$ \\
\hline $\begin{array}{l}21 \\
22 \\
23 \\
24 \\
25\end{array}$ & $\begin{array}{l}12 \\
10 \\
10 \\
11 \\
11\end{array}$ & $\begin{array}{l}.50 \\
.38 \\
.40 \\
.42 \\
.39\end{array}$ & $\begin{array}{l}\because \\
\because \because \\
\because \because\end{array}$ & $\begin{array}{l}1.6 \\
1.5 \\
1.6 \\
1.5 \\
1.5\end{array}$ & $\begin{array}{r}38 \\
37 \\
36 \\
35 \\
330\end{array}$ & $\begin{array}{r}2.0 \\
11.8 \\
1.6 \\
11.5 \\
43\end{array}$ & $\begin{array}{r}162 \\
61 \\
40 \\
35 \\
57\end{array}$ & $\begin{array}{r}37 \\
8.7 \\
3.6 \\
2.7 \\
3.8\end{array}$ & $\begin{array}{l}30 \\
29 \\
29 \\
29 \\
29\end{array}$ & $\begin{array}{c}1.0 \\
1.0 \\
.98 \\
.96 \\
.95\end{array}$ & $\begin{array}{r}53 \\
35 \\
30 \\
28 \\
--\end{array}$ & $\begin{array}{l}3.8 \\
2.0 \\
1.5 \\
1.3 \\
1.2\end{array}$ \\
\hline $\begin{array}{l}26 \\
27 \\
28 \\
29 \\
30 \\
31\end{array}$ & $\begin{array}{r}11 \\
12 \\
12 \\
13 \\
13 \\
\hdashline-\end{array}$ & $\begin{array}{l}.37 \\
.38 \\
: 37 \\
.38 \\
: 36 \\
-9\end{array}$ & $\begin{array}{r}-- \\
57 \\
130 \\
\hdashline- \\
\hdashline-\end{array}$ & $\begin{array}{l}1.4 \\
4.1 \\
9.8 \\
4.6 \\
3.4 \\
2.8\end{array}$ & $\begin{array}{r}67 \\
48 \\
42 \\
36 \\
47 \\
-\therefore\end{array}$ & $\begin{array}{l}3.6 \\
2.1 \\
1.7 \\
1.4 \\
2.5 \\
-9 .\end{array}$ & $\begin{array}{r}117 \\
33 \\
31 \\
29 \\
27 \\
46\end{array}$ & $\begin{array}{l}8.2 \\
2.1 \\
1.7 \\
1.5 \\
1.4 \\
3.2\end{array}$ & $\begin{array}{l}29 \\
37 \\
33 \\
44 \\
58 \\
56\end{array}$ & $\begin{array}{l}1.0 \\
1.5 \\
1.4 \\
1.8 \\
2.0 \\
1.8\end{array}$ & $\begin{array}{r}25 \\
24 \\
22 \\
21 \\
22 \\
-2 .\end{array}$ & $\begin{array}{c}1.0 \\
.94 \\
.85 \\
.81 \\
.84 \\
-8 .\end{array}$ \\
\hline & & 0.93 & & 317 & 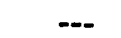 & & -.. & 1309 & 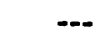 & & m & \\
\hline
\end{tabular}

TOTAL LOAD FOR YEAR: 6276.75 TONS.

NOTE: NUMBES OF MISSING DAYS OF RECORD EXCEEDED $20 \%$ OF YEAR 
Table 13. Suspended sediment discharges for Yellowstone River, 1978 and 1979 water years.

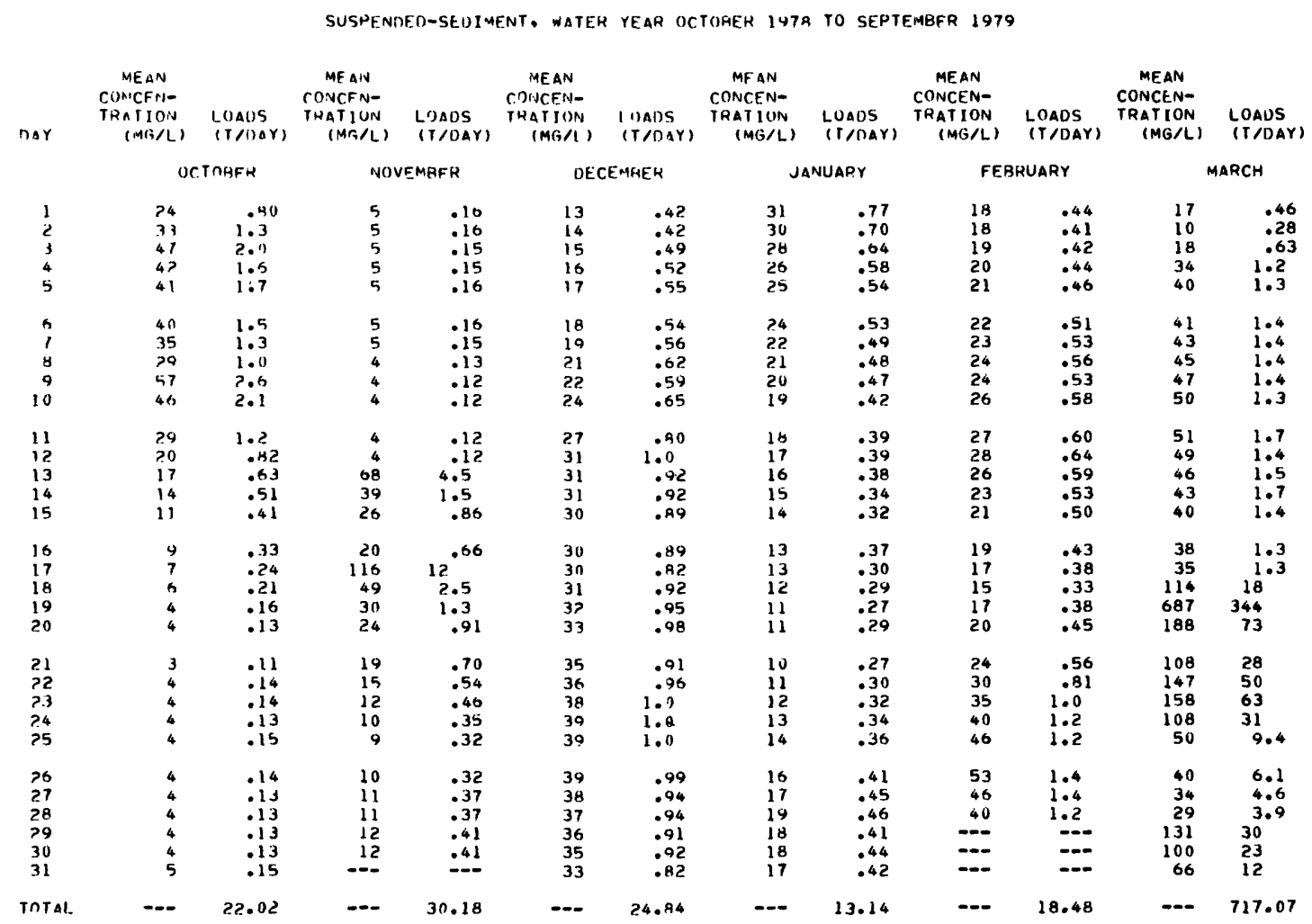

SUSPENDED-SEDIMENT, WATER YEAR OCTOBER 1918 TO SEPTEMBER 1979

\begin{tabular}{|c|c|c|c|c|c|c|c|c|c|c|c|c|}
\hline \multirow[t]{2}{*}{ i) } & $\begin{array}{l}\text { MEAN } \\
\text { CONCEN- } \\
\text { TRATION } \\
\text { (MG/L) }\end{array}$ & $\begin{array}{l}\text { LOADS } \\
\text { (I/TSAY) }\end{array}$ & $\begin{array}{l}\text { MEAN } \\
\text { CONCEN- } \\
\text { TRATION } \\
\text { (MG/L) }\end{array}$ & $\begin{array}{l}\text { LOADS } \\
\text { (T/OAY) }\end{array}$ & $\begin{array}{l}\text { MEAN } \\
\text { CONCEN- } \\
\text { TRAIION } \\
\text { (MG/L) }\end{array}$ & $\begin{array}{l}\text { LOAnS } \\
\text { (T/OAY }\end{array}$ & $\begin{array}{l}\text { MEAN } \\
\text { CONCEN- } \\
\text { TRATION } \\
\text { (MG/L) }\end{array}$ & $\begin{array}{l}\text { LUADS } \\
\text { (T/DAY) }\end{array}$ & $\begin{array}{l}\text { MEAN } \\
\text { CONCEN- } \\
\text { TRATION } \\
\text { (MG/L) }\end{array}$ & $\begin{array}{l}\text { LOADS } \\
\text { (T/OAY) }\end{array}$ & $\begin{array}{l}\text { MEAN } \\
\text { CONCEN- } \\
\text { TRATION } \\
\text { (MG/L) }\end{array}$ & $\begin{array}{l}\text { LOADS } \\
\text { (TIOAY) }\end{array}$ \\
\hline & \multicolumn{2}{|c|}{ APRIL } & \multicolumn{2}{|r|}{ MAY } & \multicolumn{2}{|c|}{ JUNE } & \multicolumn{2}{|c|}{ JULY } & \multicolumn{2}{|c|}{ AUGUST } & \multicolumn{2}{|c|}{ SEPTEMBER } \\
\hline $\begin{array}{l}1 \\
2 \\
3 \\
4 \\
5\end{array}$ & $\begin{array}{l}29 \\
33 \\
47 \\
69 \\
59\end{array}$ & $\begin{array}{l}4.4 \\
5.0 \\
6.3 \\
8.4 \\
11\end{array}$ & $\begin{array}{r}9 \\
23 \\
239 \\
105 \\
60\end{array}$ & $\begin{array}{c}2.51 \\
2.2 \\
7.8 \\
4.4\end{array}$ & $\begin{array}{l}71 \\
75 \\
79 \\
84 \\
89\end{array}$ & $\begin{array}{l}3.4 \\
3.6 \\
3.8 \\
4.0 \\
4.3\end{array}$ & $\begin{array}{r}30 \\
28 \\
65 \\
146 \\
46\end{array}$ & $\begin{array}{c}1.2 \\
1.1 \\
8.8 \\
15 \\
1.9\end{array}$ & $\begin{array}{r}35 \\
28 \\
37 \\
25 \\
296\end{array}$ & $\begin{array}{l}1.3 \\
1.1 \\
1.7 \\
1.0 \\
74\end{array}$ & $\begin{array}{l}28 \\
26 \\
24 \\
22 \\
21\end{array}$ & $\begin{array}{l}1.4 \\
1.2 \\
1.1 \\
1.0 \\
.92\end{array}$ \\
\hline $\begin{array}{r}6 \\
7 \\
8 \\
9 \\
10\end{array}$ & $\begin{array}{l}71 \\
49 \\
37 \\
23 \\
16\end{array}$ & $\begin{array}{l}7.1 \\
5.0 \\
3.5 \\
2.3 \\
1.5\end{array}$ & $\begin{array}{l}29 \\
26 \\
28 \\
31 \\
33\end{array}$ & $\begin{array}{l}2.1 \\
1.8 \\
1.9 \\
1.9 \\
2.0\end{array}$ & $\begin{array}{l}91 \\
77 \\
61 \\
49 \\
71\end{array}$ & $\begin{array}{l}4.4 \\
3.7 \\
3.0 \\
2.4 \\
4.1\end{array}$ & $\begin{array}{l}38 \\
33 \\
29 \\
26 \\
23\end{array}$ & $\begin{array}{l}1.5 \\
1.3 \\
1.1 \\
.98 \\
.86\end{array}$ & $\begin{array}{r}92 \\
39 \\
58 \\
247 \\
205\end{array}$ & $\begin{array}{c}5.3 \\
1.7 \\
3.7 \\
50 \\
42\end{array}$ & $\begin{array}{l}19 \\
18 \\
17 \\
15 \\
14\end{array}$ & $\begin{array}{l}.81 \\
.72 \\
.67 \\
.61 \\
.57\end{array}$ \\
\hline $\begin{array}{l}11 \\
12 \\
13 \\
14 \\
15\end{array}$ & $\begin{array}{r}13 \\
12 \\
11 \\
10 \\
9\end{array}$ & $\begin{array}{l}1.2 \\
1.2 \\
.97 \\
.84 \\
.71\end{array}$ & $\begin{array}{l}36 \\
40 \\
43 \\
47 \\
45\end{array}$ & $\begin{array}{l}2.4 \\
2.3 \\
2.5 \\
2.6 \\
2.5\end{array}$ & $\begin{array}{l}70 \\
64 \\
60 \\
57 \\
54\end{array}$ & $\begin{array}{l}3.3 \\
2.9 \\
2.7 \\
2.5 \\
2.3\end{array}$ & $\begin{array}{r}65 \\
54 \\
37 \\
169 \\
65\end{array}$ & $\begin{array}{c}3.4 \\
2.3 \\
1.5 \\
15 \\
2.9\end{array}$ & $\begin{array}{l}51 \\
50 \\
49 \\
42 \\
35\end{array}$ & $\begin{array}{l}3.2 \\
2.8 \\
2.5 \\
2.1 \\
1.6\end{array}$ & $\begin{array}{l}14 \\
13 \\
13 \\
12 \\
12\end{array}$ & $\begin{array}{l}.54 \\
.49 \\
.50 \\
.45 \\
.45\end{array}$ \\
\hline $\begin{array}{l}16 \\
17 \\
18 \\
19 \\
20\end{array}$ & $\begin{array}{r}R \\
9 \\
9 \\
10 \\
11\end{array}$ & $\begin{array}{l}.61 \\
.61 \\
.63 \\
.69 \\
.79\end{array}$ & $\begin{array}{l}41 \\
38 \\
37 \\
66 \\
47\end{array}$ & $\begin{array}{l}2.2 \\
2.0 \\
2.0 \\
4.5 \\
2.6\end{array}$ & $\begin{array}{l}51 \\
49 \\
46 \\
44 \\
57\end{array}$ & $\begin{array}{l}2.2 \\
2.1 \\
2.1 \\
1.9 \\
2.9\end{array}$ & $\begin{array}{l}42 \\
31 \\
26 \\
25 \\
25\end{array}$ & $\begin{array}{l}1.7 \\
1.2 \\
.96 \\
.93 \\
.91\end{array}$ & $\begin{array}{r}30 \\
126 \\
230 \\
38 \\
145\end{array}$ & $\begin{array}{l}51.3 \\
56 \\
2.7 \\
22\end{array}$ & $\begin{array}{l}11 \\
11 \\
10 \\
10 \\
10\end{array}$ & $\begin{array}{l}.41 \\
.40 \\
.38 \\
.35 \\
.36\end{array}$ \\
\hline $\begin{array}{l}21 \\
22 \\
23 \\
24 \\
25\end{array}$ & $\begin{array}{l}12 \\
13 \\
14 \\
12 \\
12\end{array}$ & $\begin{array}{l}.84 \\
.84 \\
.97 \\
.75 \\
.87\end{array}$ & $\begin{array}{l}45 \\
44 \\
44 \\
46 \\
48\end{array}$ & $\begin{array}{l}2.4 \\
2.3 \\
2.3 \\
2.3 \\
2.4\end{array}$ & $\begin{array}{l}34 \\
34 \\
34 \\
34 \\
34\end{array}$ & $\begin{array}{l}1.5 \\
1.4 \\
1.4 \\
1.3 \\
1.3\end{array}$ & $\begin{array}{l}25 \\
83 \\
40 \\
37 \\
35\end{array}$ & $\begin{array}{l}.93 \\
4.2 \\
1.5 \\
1.4 \\
1.4\end{array}$ & $\begin{array}{l}89 \\
67 \\
40 \\
35 \\
31\end{array}$ & $\begin{array}{l}7.1 \\
5.7 \\
2.8 \\
2.2 \\
1.8\end{array}$ & $\begin{array}{l}10 \\
10 \\
11 \\
11 \\
11\end{array}$ & $\begin{array}{l}.36 \\
.35 \\
.37 \\
.40 \\
.41\end{array}$ \\
\hline $\begin{array}{l}26 \\
77 \\
28 \\
29 \\
30 \\
31\end{array}$ & $\begin{array}{r}43 \\
15 \\
12 \\
9 \\
7 \\
-2\end{array}$ & $\begin{array}{l}3.7 \\
1.0 \\
.83 \\
.64 \\
.55 \\
.--\end{array}$ & $\begin{array}{l}51 \\
54 \\
57 \\
60 \\
64 \\
67\end{array}$ & $\begin{array}{l}2.6 \\
2.7 \\
2.8 \\
2.9 \\
3.1 \\
3.4\end{array}$ & $\begin{array}{r}34 \\
34 \\
34 \\
48 \\
33 \\
- \\
-\end{array}$ & $\begin{array}{l}1.3 \\
1.3 \\
1.4 \\
2.3 \\
1.4 \\
-0 .\end{array}$ & $\begin{array}{r}33 \\
31 \\
29 \\
27 \\
132 \\
51\end{array}$ & $\begin{array}{c}1.2 \\
1.1 \\
1.0 \\
11.95 \\
2.1\end{array}$ & $\begin{array}{l}27 \\
39 \\
30 \\
54 \\
33 \\
30\end{array}$ & $\begin{array}{l}1.5 \\
2.4 \\
1.6 \\
3.9 \\
1.7 \\
1.5\end{array}$ & $\begin{array}{r}11 \\
12 \\
13 \\
14 \\
16 \\
\end{array}$ & $\begin{array}{l}.38 \\
.41 \\
.46 \\
.51 \\
.56 \\
-.-\end{array}$ \\
\hline TOTAL & --- & 73.64 & $-\infty$ & 103.41 & $-\infty$ & 76.2 & $-\infty$ & 91.32 & $-\infty$ & 359.2 & $\infty$ & 17.54 \\
\hline TOTAL & $A \cap F \cap R$ & & .04 & & & & & & & & & \\
\hline
\end{tabular}


Table 14. Total organic nitrogen for Steiner Branch, 1978 and 1979 water years, in pounds.

TOTAL ORGANIC NITROGEN IN POUNDS, WATER YEAR OCTOBER 1977 TO SEPTEMAER 1978

\begin{tabular}{|c|c|c|c|c|c|c|c|c|c|c|c|c|}
\hline nar & $\mathrm{OCr}$ & Nov & DEC & JAN & FER & MAR & $\triangle P B$ & MAY & JUN & JUL & AUG & SEP \\
\hline $\begin{array}{l}1 \\
2 \\
3 \\
4 \\
5\end{array}$ & $\begin{array}{l}2.4 \\
2.1 \\
1.4 \\
1.6 \\
1.0\end{array}$ & $\begin{array}{l}2.4 \\
5.0 \\
3.4 \\
2.7 \\
2.4\end{array}$ & $\begin{array}{l}1.9 \\
1.4 \\
1.6 \\
1.4 \\
1.4\end{array}$ & $\begin{array}{l}1.9 \\
1.9 \\
1.9 \\
1.9 \\
1.9\end{array}$ & $\begin{array}{l}1.2 \\
1.2 \\
1.2 \\
1.2 \\
1.2\end{array}$ & $\begin{array}{l}1.2 \\
1.2 \\
1.4 \\
1.4 \\
1.4\end{array}$ & $\begin{array}{c}9.4 \\
10 \\
9.4 \\
9.4 \\
6.9\end{array}$ & $\begin{array}{l}5.0 \\
4.5 \\
4.5 \\
4.5 \\
4.5\end{array}$ & $\begin{array}{l}9.3 \\
7.5 \\
6.9 \\
6.5 \\
6.2\end{array}$ & $\begin{array}{c}884 \\
38 \\
19 \\
13 \\
9.3\end{array}$ & $\begin{array}{l}24 \\
20 \\
17 \\
15 \\
14\end{array}$ & $\begin{array}{l}7.8 \\
7.8 \\
7.8 \\
7.3 \\
6.9\end{array}$ \\
\hline $\begin{array}{r}6 \\
1 \\
8 \\
9 \\
10\end{array}$ & $\begin{array}{l}1.5 \\
1.6 \\
4.6 \\
3.4 \\
3.0\end{array}$ & $\begin{array}{l}2.7 \\
2.7 \\
2.7 \\
3.0 \\
2.7\end{array}$ & $\begin{array}{l}1.4 \\
1.4 \\
1.6 \\
1.0 \\
2.1\end{array}$ & $\begin{array}{l}1.6 \\
1.6 \\
1.6 \\
1.4 \\
1.4\end{array}$ & $\begin{array}{l}1.2 \\
1.2 \\
1.2 \\
1.2 \\
1.4\end{array}$ & $\begin{array}{l}1.4 \\
1.4 \\
1.4 \\
1.4 \\
1.4\end{array}$ & $\begin{array}{r}133 \\
30 \\
16 \\
11 \\
33\end{array}$ & $\begin{array}{l}4 . ? \\
3.9 \\
5.2 \\
4.5 \\
3.9\end{array}$ & $\begin{array}{l}5.9 \\
5.9 \\
6.2 \\
5.3 \\
5.0\end{array}$ & $\begin{array}{r}1553 \\
110 \\
43 \\
30 \\
17\end{array}$ & $\begin{array}{l}13 \\
13 \\
13 \\
12 \\
12\end{array}$ & $\begin{array}{l}6.9 \\
6.9 \\
6.5 \\
6.5 \\
6.5\end{array}$ \\
\hline $\begin{array}{l}11 \\
12 \\
13 \\
14 \\
15\end{array}$ & $\begin{array}{l}3.0 \\
2.7 \\
2.4 \\
2.1 \\
2.1\end{array}$ & $\begin{array}{l}2.4 \\
2.1 \\
1.9 \\
2.1 \\
2.1\end{array}$ & $\begin{array}{l}2.1 \\
2.4 \\
2.1 \\
2.1 \\
2.1\end{array}$ & $\begin{array}{l}1.4 \\
1.4 \\
1.4 \\
1.4 \\
1.4\end{array}$ & $\begin{array}{l}1.2 \\
1.4 \\
1.4 \\
1.4 \\
1.4\end{array}$ & $\begin{array}{l}1.6 \\
1.6 \\
1.6 \\
1.6 \\
1.6\end{array}$ & $\begin{array}{l}16 \\
11 \\
8.1 \\
6.4 \\
6.0\end{array}$ & $\begin{array}{r}3.9 \\
25 \\
1834 \\
328 \\
60\end{array}$ & $\begin{array}{l}4.7 \\
4.5 \\
4.2 \\
4.2 \\
4.2\end{array}$ & $\begin{array}{c}12 \\
20 \\
16 \\
10 \\
8.1\end{array}$ & $\begin{array}{l}12 \\
11 \\
11 \\
11 \\
11\end{array}$ & $\begin{array}{l}6.5 \\
8.3 \\
22 \\
23 \\
11\end{array}$ \\
\hline $\begin{array}{l}16 \\
17 \\
18 \\
19 \\
20\end{array}$ & $\begin{array}{l}2.1 \\
1.9 \\
1.9 \\
1.9 \\
1.9\end{array}$ & $\begin{array}{l}2.1 \\
2.1 \\
1.9 \\
1.9 \\
1.9\end{array}$ & $\begin{array}{l}2.1 \\
2.1 \\
2.1 \\
2.1 \\
1.9\end{array}$ & $\begin{array}{l}1.4 \\
1.6 \\
1.6 \\
1.6 \\
1.6\end{array}$ & $\begin{array}{l}1.2 \\
1.2 \\
1.2 \\
1.2 \\
1.2\end{array}$ & $\begin{array}{r}1.6 \\
1.6 \\
1.6 \\
7.5 \\
67\end{array}$ & $\begin{array}{l}5.2 \\
4.8 \\
24 \\
10 \\
9.6\end{array}$ & $\begin{array}{l}55 \\
40 \\
30 \\
24 \\
21\end{array}$ & $\begin{array}{r}242 \\
4947 \\
73 \\
17 \\
14\end{array}$ & $\begin{array}{r}8.7 \\
8.1 \\
7.0 \\
6.5 \\
1319\end{array}$ & $\begin{array}{l}15 \\
11 \\
14 \\
21 \\
12\end{array}$ & $\begin{array}{c}9.2 \\
15 \\
712 \\
13 \\
89\end{array}$ \\
\hline $\begin{array}{l}21 \\
22 \\
23 \\
24 \\
25\end{array}$ & $\begin{array}{l}1.9 \\
1.5 \\
1.6 \\
1.9 \\
2.1\end{array}$ & $\begin{array}{l}1.9 \\
1.4 \\
1.4 \\
1.2 \\
1.2\end{array}$ & $\begin{array}{l}1.9 \\
1.9 \\
1.6 \\
1.6 \\
1.6\end{array}$ & $\begin{array}{l}1.6 \\
1.6 \\
1.6 \\
1.6 \\
1.6\end{array}$ & $\begin{array}{l}1.2 \\
1.2 \\
1.2 \\
1.2 \\
1.2\end{array}$ & $\begin{array}{r}292 \\
209 \\
48 \\
18 \\
10\end{array}$ & $\begin{array}{l}9.1 \\
7.7 \\
8.6 \\
8.1 \\
7.2\end{array}$ & $\begin{array}{l}18 \\
16 \\
17 \\
15 \\
13\end{array}$ & $\begin{array}{c}10 \\
1.00 \\
6.0 \\
5.06 \\
323\end{array}$ & $\begin{array}{r}126 \\
110 \\
69 \\
45 \\
37\end{array}$ & $\begin{array}{l}11 \\
11 \\
10 \\
9.7 \\
8.8\end{array}$ & $\begin{array}{l}24 \\
14 \\
11 \\
9.7 \\
8.8\end{array}$ \\
\hline $\begin{array}{l}26 \\
27 \\
28 \\
29 \\
30 \\
31\end{array}$ & $\begin{array}{l}2.1 \\
1.6 \\
1.6 \\
1.4 \\
1.4 \\
1.4\end{array}$ & $\begin{array}{l}1.2 \\
1.2 \\
1.4 \\
1.6 \\
1.9 \\
-. .\end{array}$ & $\begin{array}{l}1.6 \\
1.6 \\
1.6 \\
1.6 \\
2.1 \\
2.1\end{array}$ & $\begin{array}{l}1.6 \\
1.4 \\
1.4 \\
1.2 \\
1.2 \\
1.2\end{array}$ & \begin{tabular}{l}
1.2 \\
1.2 \\
1.2 \\
\hdashline-.2 \\
$-\cdots$.
\end{tabular} & $\begin{array}{r}8.1 \\
9.4 \\
11 \\
8.7 \\
8.7 \\
11\end{array}$ & $\begin{array}{l}6.0 \\
5.6 \\
5.6 \\
5.0 \\
5.2 \\
-.\end{array}$ & $\begin{array}{l}12 \\
15 \\
18 \\
12 \\
11 \\
9.3\end{array}$ & $\begin{array}{r}19 \\
8.7 \\
6.0 \\
5.1 \\
41 \\
-.-\end{array}$ & $\begin{array}{l}58 \\
34 \\
26 \\
24 \\
22 \\
51\end{array}$ & $\begin{array}{l}9.2 \\
13 \\
36 \\
17 \\
9.7 \\
8.8\end{array}$ & $\begin{array}{l}8.3 \\
7.8 \\
7.4 \\
7.4 \\
7.4 \\
-.-\end{array}$ \\
\hline $\begin{array}{l}\text { MAX } \\
\text { MIN }\end{array}$ & $\begin{array}{l}4.6 \\
1.4\end{array}$ & $\begin{array}{l}5.0 \\
1.2\end{array}$ & $\begin{array}{l}2.4 \\
1.4\end{array}$ & $\begin{array}{l}1.9 \\
1.2\end{array}$ & $\begin{array}{l}1.4 \\
1.2\end{array}$ & $\begin{array}{l}29 ? \\
1 . ?\end{array}$ & $\begin{array}{l}133 \\
4.8\end{array}$ & $\begin{array}{r}1830 \\
3.9\end{array}$ & $\begin{array}{r}4950 \\
4 . ?\end{array}$ & $\begin{array}{r}1550 \\
6.5\end{array}$ & $\begin{array}{r}36 \\
8.8\end{array}$ & $\begin{array}{l}712 \\
6.5\end{array}$ \\
\hline
\end{tabular}

TOTAL ORGANIC NITROGEN IN POUNOS, WATER YEAR OCTOBER 1978 TO SEPTEMEER 1979

\begin{tabular}{|c|c|c|c|c|c|c|c|c|c|c|c|c|}
\hline DAY & OCF & NOV & DFC & JAN & FEB & MAR & APR & MAY & JUN & JUL & AUG & SEP \\
\hline $\begin{array}{l}1 \\
2 \\
3 \\
4 \\
5\end{array}$ & $\begin{array}{l}9.7 \\
11 \\
13 \\
11 \\
14\end{array}$ & $\begin{array}{r}12 \\
12 \\
12 \\
12 \\
12\end{array}$ & $\begin{array}{l}4.2 \\
4.2 \\
5.9 \\
5.4 \\
5.0\end{array}$ & $\begin{array}{l}2.3 \\
2.0 \\
2.0 \\
1.8 \\
1.8\end{array}$ & $\begin{array}{l}2.0 \\
1.6 \\
1.8 \\
1.8 \\
1.8\end{array}$ & $\begin{array}{l}3.1 \\
3.1 \\
4.6 \\
6.4 \\
5.9\end{array}$ & $\begin{array}{l}33 \\
40 \\
21 \\
21 \\
16\end{array}$ & $\begin{array}{c}3.5 \\
5.4 \\
10 \\
7.0 \\
6.8\end{array}$ & $\begin{array}{l}1.40 \\
1.20 \\
1.20 \\
1.20 \\
1.30\end{array}$ & $\begin{array}{r}.80 \\
.80 \\
.69 \\
1.00 \\
.50\end{array}$ & $\begin{array}{l}5.5 \\
5.5 \\
9.8 \\
11 \\
358\end{array}$ & $\begin{array}{l}18 \\
17 \\
16 \\
21 \\
13\end{array}$ \\
\hline $\begin{array}{r}6 \\
7 \\
8 \\
9 \\
10\end{array}$ & $\begin{array}{l}12 \\
11 \\
11 \\
17 \\
16\end{array}$ & $\begin{array}{l}12 \\
11 \\
11 \\
11 \\
11\end{array}$ & $\begin{array}{l}4.2 \\
4.6 \\
4.2 \\
3.5 \\
3.1\end{array}$ & $\begin{array}{l}1.8 \\
1.8 \\
2.0 \\
2.0 \\
1.8\end{array}$ & $\begin{array}{l}2.0 \\
2.0 \\
1.8 \\
1.8 \\
1.8\end{array}$ & $\begin{array}{l}5.4 \\
5.9 \\
5.0 \\
4.6 \\
4.2\end{array}$ & $\begin{array}{l}21 \\
10 \\
11 \\
9.5 \\
7.5\end{array}$ & $\begin{array}{l}6.8 \\
6.3 \\
5.6 \\
4.6 \\
3.9\end{array}$ & $\begin{array}{l}1.100 \\
1.10 \\
1.10 \\
1.10 \\
1.90\end{array}$ & $\begin{array}{l}.46 \\
.46 \\
.42 \\
.42 \\
.42\end{array}$ & $\begin{array}{l}27 \\
7.0 \\
7.0 \\
166 \\
190\end{array}$ & $\begin{array}{l}13 \\
14 \\
14 \\
13 \\
14\end{array}$ \\
\hline $\begin{array}{l}11 \\
12 \\
13 \\
14 \\
15\end{array}$ & $\begin{array}{l}13 \\
12 \\
11 \\
11 \\
11\end{array}$ & $\begin{array}{l}10 \\
9.7 \\
25 \\
15 \\
13\end{array}$ & $\begin{array}{l}3.8 \\
3.6 \\
3.8 \\
3.8 \\
3.8\end{array}$ & $\begin{array}{l}1.6 \\
1.8 \\
2.3 \\
2.0 \\
2.0\end{array}$ & $\begin{array}{l}1.8 \\
1.8 \\
1.8 \\
1.8 \\
1.8\end{array}$ & $\begin{array}{l}4.6 \\
5.4 \\
6.9 \\
8.7 \\
8.0\end{array}$ & $\begin{array}{r}8.0 \\
11 \\
9.8 \\
7.5 \\
6.0\end{array}$ & $\begin{array}{l}4.0 \\
3.2 \\
2.9 \\
2.8 \\
2.4\end{array}$ & $\begin{array}{l}1.10 \\
1.00 \\
.93 \\
.86 \\
.86\end{array}$ & $\begin{array}{r}.42 \\
.42 \\
.54 \\
133.0 \\
19.00\end{array}$ & $\begin{array}{l}52 \\
22 \\
20 \\
18 \\
16\end{array}$ & $\begin{array}{l}12 \\
11 \\
10 \\
9.6 \\
8.9\end{array}$ \\
\hline $\begin{array}{l}16 \\
17 \\
18 \\
19 \\
20\end{array}$ & $\begin{array}{l}12 \\
11 \\
12 \\
12 \\
12\end{array}$ & $\begin{array}{l}12 \\
60 \\
22 \\
9.3 \\
6.9\end{array}$ & $\begin{array}{l}3.8 \\
3.5 \\
3.5 \\
3.5 \\
3.5\end{array}$ & $\begin{array}{l}1.8 \\
2.0 \\
2.5 \\
2.8 \\
3.1\end{array}$ & $\begin{array}{l}1.6 \\
1.8 \\
1.8 \\
1.8 \\
1.8\end{array}$ & $\begin{array}{r}7.5 \\
8.0 \\
67 \\
473 \\
220\end{array}$ & $\begin{array}{l}5.6 \\
5.2 \\
4.4 \\
4.4 \\
4.8\end{array}$ & $\begin{array}{l}2.2 \\
2.2 \\
2.4 \\
3.7 \\
2.3\end{array}$ & $\begin{array}{r}.80 \\
.75 \\
.80 \\
.80 \\
1.20\end{array}$ & $\begin{array}{l}7.40 \\
6.80 \\
6.10 \\
5.50 \\
5.50\end{array}$ & $\begin{array}{r}14 \\
69 \\
212 \\
35 \\
133\end{array}$ & $\begin{array}{l}8.9 \\
9.6 \\
9.6 \\
8.3 \\
9.6\end{array}$ \\
\hline $\begin{array}{l}? 1 \\
22 \\
23 \\
24 \\
? 5\end{array}$ & $\begin{array}{l}13 \\
12 \\
13 \\
13 \\
16\end{array}$ & $\begin{array}{l}5.9 \\
5.4 \\
6.9 \\
5.9 \\
5.0\end{array}$ & $\begin{array}{l}4.2 \\
3.1 \\
3.1 \\
2.1 \\
2.8\end{array}$ & $\begin{array}{l}3.5 \\
3.5 \\
3.1 \\
2.8 \\
2.8\end{array}$ & $\begin{array}{l}2.0 \\
2.0 \\
4.2 \\
3.5 \\
3.1\end{array}$ & $\begin{array}{r}160 \\
259 \\
412 \\
259 \\
54\end{array}$ & $\begin{array}{l}4.4 \\
3.7 \\
3.4 \\
3.4 \\
4.0\end{array}$ & $\begin{array}{l}2.0 \\
2.0 \\
2.0 \\
1.7 \\
1.7\end{array}$ & $\begin{array}{l}.86 \\
.75 \\
.75 \\
.69 \\
.64\end{array}$ & $\begin{array}{r}5.50 \\
11.00 \\
3.80 \\
6.80 \\
9.00\end{array}$ & $\begin{array}{l}44 \\
28 \\
32 \\
27 \\
23\end{array}$ & $\begin{array}{l}8.3 \\
7.7 \\
8.3 \\
8.3 \\
8.3\end{array}$ \\
\hline $\begin{array}{l}26 \\
27 \\
28 \\
29 \\
30 \\
.31\end{array}$ & $\begin{array}{l}15 \\
14 \\
13 \\
13 \\
13 \\
13\end{array}$ & $\begin{array}{l}5.0 \\
5.0 \\
4.6 \\
5.0 \\
5.0 \\
-.0\end{array}$ & $\begin{array}{l}2.8 \\
2.5 \\
2.8 \\
2.8 \\
2.5 \\
2.5\end{array}$ & $\begin{array}{l}2.8 \\
2.5 \\
2.0 \\
1.6 \\
2.3 \\
1.8\end{array}$ & \begin{tabular}{l}
2.8 \\
2.8 \\
2.8 \\
\hdashline.- \\
$\cdots--$
\end{tabular} & $\begin{array}{r}33 \\
21 \\
21 \\
70 \\
128 \\
59\end{array}$ & $\begin{array}{l}6.0 \\
4.8 \\
4.4 \\
4.4 \\
4.3 \\
-.0 .\end{array}$ & $\begin{array}{l}1.7 \\
1.7 \\
1.6 \\
1.5 \\
1.5 \\
1.5\end{array}$ & $\begin{array}{l}.64 \\
.64 \\
.69 \\
.93 \\
.86 \\
.0\end{array}$ & $\begin{array}{r}6.80 \\
5.50 \\
5.50 \\
5.50 \\
16.00 \\
6.80\end{array}$ & $\begin{array}{l}21 \\
29 \\
23 \\
31 \\
20 \\
18\end{array}$ & $\begin{array}{l}7.0 \\
6.5 \\
6.0 \\
7.0 \\
6.0 \\
-0 .\end{array}$ \\
\hline $\begin{array}{l}\text { MAX } \\
\text { MIN }\end{array}$ & $\begin{array}{r}17 \\
9.7\end{array}$ & $\begin{array}{l}60 \\
4.6\end{array}$ & $\begin{array}{l}5.9 \\
2.5\end{array}$ & $\begin{array}{l}3.5 \\
1.6\end{array}$ & $\begin{array}{l}4.2 \\
1.6\end{array}$ & $\begin{array}{l}47 \overline{3} \\
3.1\end{array}$ & $\begin{array}{r}40 \\
3.4\end{array}$ & $\begin{array}{r}10 \\
1.5\end{array}$ & $\begin{array}{l}1.9 \\
.64\end{array}$ & $\begin{array}{r}133 \\
.42\end{array}$ & $\begin{array}{l}358 \\
5.5\end{array}$ & $\begin{array}{r}21 \\
6.0\end{array}$ \\
\hline
\end{tabular}

WTR YR 1979 MAX 473 MIN $\quad 42$ 
Table 15. Total nitrogen for Steiner Branch, 1978 and 1979 water years, in pounds.

TOTAL NITROGEN IN POUNDS, WATER YEAR OCTOBER 1977 TO SEPTEMBER 1978

\begin{tabular}{|c|c|c|c|c|c|c|c|c|c|c|c|c|}
\hline DAY & OCT & Nov & DEC & JAN & FER & MAR & APR & MAY & JUN & JUL & AUG & SEP \\
\hline $\begin{array}{l}1 \\
2 \\
3 \\
4 \\
5\end{array}$ & $\begin{array}{l}29 \\
27 \\
24 \\
24 \\
25\end{array}$ & $\begin{array}{l}28 \\
38 \\
32 \\
29 \\
28\end{array}$ & $\begin{array}{l}25 \\
24 \\
24 \\
22 \\
22\end{array}$ & $\begin{array}{l}25 \\
25 \\
25 \\
25 \\
25\end{array}$ & $\begin{array}{l}21 \\
21 \\
21 \\
21 \\
21\end{array}$ & $\begin{array}{l}21 \\
21 \\
22 \\
21 \\
21\end{array}$ & $\begin{array}{l}50 \\
50 \\
50 \\
50 \\
30\end{array}$ & $\begin{array}{l}28 \\
26 \\
26 \\
26 \\
26\end{array}$ & $\begin{array}{l}59 \\
45 \\
42 \\
40 \\
38\end{array}$ & $\begin{array}{r}1137 \\
117 \\
78 \\
60 \\
49\end{array}$ & $\begin{array}{l}78 \\
67 \\
59 \\
54 \\
51\end{array}$ & $\begin{array}{l}33 \\
33 \\
33 \\
31 \\
30\end{array}$ \\
\hline $\begin{array}{r}6 \\
7 \\
8 \\
9 \\
10\end{array}$ & $\begin{array}{l}24 \\
24 \\
36 \\
32 \\
31\end{array}$ & $\begin{array}{l}29 \\
29 \\
29 \\
31 \\
29\end{array}$ & $\begin{array}{l}22 \\
22 \\
24 \\
25 \\
27\end{array}$ & $\begin{array}{l}24 \\
24 \\
24 \\
22 \\
22\end{array}$ & $\begin{array}{l}21 \\
21 \\
21 \\
21 \\
22\end{array}$ & $\begin{array}{l}21 \\
21 \\
21 \\
21 \\
22\end{array}$ & $\begin{array}{r}317 \\
125 \\
69 \\
52 \\
119\end{array}$ & $\begin{array}{l}25 \\
24 \\
30 \\
26 \\
24\end{array}$ & $\begin{array}{l}36 \\
36 \\
38 \\
33 \\
31\end{array}$ & $\begin{array}{r}1873 \\
217 \\
137 \\
112 \\
80\end{array}$ & $\begin{array}{l}49 \\
49 \\
48 \\
46 \\
45\end{array}$ & $\begin{array}{l}30 \\
30 \\
28 \\
28 \\
28\end{array}$ \\
\hline $\begin{array}{l}11 \\
12 \\
13 \\
14 \\
15\end{array}$ & $\begin{array}{l}31 \\
29 \\
28 \\
27 \\
27\end{array}$ & $\begin{array}{l}28 \\
27 \\
25 \\
27 \\
27\end{array}$ & $\begin{array}{l}27 \\
28 \\
27 \\
27 \\
27\end{array}$ & $\begin{array}{l}22 \\
22 \\
22 \\
22 \\
22\end{array}$ & $\begin{array}{l}21 \\
22 \\
22 \\
22 \\
21\end{array}$ & $\begin{array}{l}24 \\
24 \\
24 \\
24 \\
24\end{array}$ & $\begin{array}{l}69 \\
50 \\
41 \\
34 \\
33\end{array}$ & $\begin{array}{r}24 \\
49 \\
2831 \\
765 \\
292\end{array}$ & $\begin{array}{l}30 \\
28 \\
27 \\
27 \\
27\end{array}$ & $\begin{array}{l}66 \\
88 \\
78 \\
59 \\
53\end{array}$ & $\begin{array}{l}45 \\
43 \\
42 \\
42 \\
43\end{array}$ & $\begin{array}{l}28 \\
34 \\
73 \\
75 \\
43\end{array}$ \\
\hline $\begin{array}{l}16 \\
17 \\
18 \\
19 \\
20\end{array}$ & $\begin{array}{l}27 \\
25 \\
25 \\
25 \\
25\end{array}$ & $\begin{array}{l}27 \\
27 \\
25 \\
25 \\
25\end{array}$ & $\begin{array}{l}27 \\
27 \\
27 \\
27 \\
25\end{array}$ & $\begin{array}{l}22 \\
24 \\
24 \\
24 \\
24\end{array}$ & $\begin{array}{l}21 \\
21 \\
21 \\
21 \\
21\end{array}$ & $\begin{array}{r}24 \\
24 \\
24 \\
45 \\
146\end{array}$ & $\begin{array}{l}30 \\
28 \\
94 \\
58 \\
47\end{array}$ & $\begin{array}{l}263 \\
196 \\
154 \\
126 \\
111\end{array}$ & $\begin{array}{r}345 \\
5994 \\
197 \\
101 \\
75\end{array}$ & $\begin{array}{r}55 \\
53 \\
49 \\
52 \\
1844\end{array}$ & $\begin{array}{l}54 \\
43 \\
51 \\
70 \\
45\end{array}$ & $\begin{array}{r}39 \\
57 \\
1011 \\
49 \\
261\end{array}$ \\
\hline $\begin{array}{l}21 \\
2.2 \\
23 \\
24 \\
25\end{array}$ & $\begin{array}{l}25 \\
24 \\
24 \\
25 \\
27\end{array}$ & $\begin{array}{l}25 \\
22 \\
22 \\
21 \\
21\end{array}$ & $\begin{array}{l}25 \\
25 \\
24 \\
24 \\
24\end{array}$ & $\begin{array}{l}24 \\
24 \\
24 \\
24 \\
24\end{array}$ & $\begin{array}{l}21 \\
21 \\
21 \\
21 \\
21\end{array}$ & $\begin{array}{r}496 \\
409 \\
149 \\
95 \\
60\end{array}$ & $\begin{array}{l}45 \\
39 \\
43 \\
41 \\
38\end{array}$ & $\begin{array}{l}96 \\
86 \\
91 \\
82 \\
73\end{array}$ & $\begin{array}{r}60 \\
49 \\
45 \\
42 \\
489\end{array}$ & $\begin{array}{l}348 \\
252 \\
175 \\
126 \\
109\end{array}$ & $\begin{array}{l}42 \\
42 \\
40 \\
39 \\
36\end{array}$ & $\begin{array}{l}92 \\
61 \\
52 \\
46 \\
43\end{array}$ \\
\hline $\begin{array}{l}26 \\
27 \\
28 \\
29 \\
30 \\
31\end{array}$ & $\begin{array}{l}27 \\
24 \\
24 \\
22 \\
22 \\
25\end{array}$ & $\begin{array}{r}21 \\
21 \\
22 \\
24 \\
25 \\
-\end{array}$ & $\begin{array}{l}24 \\
24 \\
24 \\
24 \\
25 \\
25\end{array}$ & $\begin{array}{l}24 \\
22 \\
22 \\
21 \\
21 \\
21\end{array}$ & $\begin{array}{r}21 \\
21 \\
21 \\
-\infty- \\
\hdashline-\end{array}$ & $\begin{array}{r}50 \\
55 \\
60 \\
50 \\
55 \\
-\end{array}$ & $\begin{array}{r}33 \\
31 \\
31 \\
31 \\
30 \\
-\end{array}$ & $\begin{array}{l}67 \\
82 \\
96 \\
69 \\
64 \\
54\end{array}$ & $\begin{array}{r}88 \\
56 \\
45 \\
40 \\
98 \\
-\end{array}$ & $\begin{array}{r}153 \\
102 \\
83 \\
78 \\
72 \\
139\end{array}$ & $\begin{array}{r}37 \\
49 \\
105 \\
59 \\
39 \\
36\end{array}$ & $\begin{array}{r}41 \\
39 \\
37 \\
37 \\
37 \\
-\end{array}$ \\
\hline MEAN & 26 & 26 & 25 & 23 & 21 & 69 & 59 & 191 & 275 & 255 & 50 & 82 \\
\hline WTR & & & & MAX & 5994 & & & & & & & \\
\hline
\end{tabular}

TOTAL NITROGEN IN POUNOS, NATER YEAR DCTOBER 1978 TO SEPTEMBER 1979

\begin{tabular}{|c|c|c|c|c|c|c|c|c|c|c|c|c|}
\hline DAY & DCT & NOV & OEC & JAN & FEB & MAR & APR & MAY & JUN & JUL & AUG & SEP \\
\hline $\begin{array}{l}1 \\
2 \\
3 \\
4 \\
5\end{array}$ & $\begin{array}{l}46 \\
50 \\
57 \\
50 \\
61\end{array}$ & $\begin{array}{l}54 \\
54 \\
54 \\
54 \\
54\end{array}$ & $\begin{array}{l}54 \\
54 \\
62 \\
60 \\
58\end{array}$ & $\begin{array}{l}42 \\
40 \\
40 \\
38 \\
38\end{array}$ & $\begin{array}{l}40 \\
37 \\
38 \\
38 \\
38\end{array}$ & $\begin{array}{l}48 \\
44 \\
56 \\
64 \\
62\end{array}$ & $\begin{array}{l}400 \\
437 \\
330 \\
330 \\
296\end{array}$ & $\begin{array}{l}158 \\
189 \\
249 \\
210 \\
207\end{array}$ & $\begin{array}{l}107 \\
101 \\
101 \\
101 \\
104\end{array}$ & $\begin{array}{l}85 \\
85 \\
80 \\
93 \\
70\end{array}$ & $\begin{array}{r}60 \\
60 \\
75 \\
77 \\
517\end{array}$ & $\begin{array}{l}83 \\
81 \\
78 \\
92 \\
70\end{array}$ \\
\hline $\begin{array}{r}6 \\
7 \\
8 \\
9 \\
10 .\end{array}$ & $\begin{array}{l}55 \\
50 \\
50 \\
73 \\
69\end{array}$ & $\begin{array}{l}54 \\
50 \\
50 \\
50 \\
50\end{array}$ & $\begin{array}{l}54 \\
56 \\
54 \\
50 \\
48\end{array}$ & $\begin{array}{l}38 \\
38 \\
40 \\
40 \\
38\end{array}$ & $\begin{array}{l}40 \\
40 \\
38 \\
38 \\
38\end{array}$ & $\begin{array}{l}60 \\
61 \\
58 \\
56 \\
54\end{array}$ & $\begin{array}{l}330 \\
246 \\
252 \\
239 \\
217\end{array}$ & $\begin{array}{l}207 \\
201 \\
192 \\
176 \\
164\end{array}$ & $\begin{array}{r}96 \\
98 \\
98 \\
98 \\
120\end{array}$ & $\begin{array}{l}67 \\
67 \\
65 \\
65 \\
65\end{array}$ & $\begin{array}{r}78 \\
47 \\
47 \\
322 \\
381\end{array}$ & $\begin{array}{l}67 \\
72 \\
72 \\
70 \\
72\end{array}$ \\
\hline $\begin{array}{l}11 \\
12 \\
13 \\
14 \\
15\end{array}$ & $\begin{array}{l}72 \\
55 \\
52 \\
50 \\
52\end{array}$ & $\begin{array}{l}48 \\
46 \\
97 \\
65 \\
57\end{array}$ & $\begin{array}{l}59 \\
59 \\
52 \\
52 \\
52\end{array}$ & $\begin{array}{l}37 \\
38 \\
42 \\
40 \\
40\end{array}$ & $\begin{array}{l}38 \\
38 \\
38 \\
38 \\
38\end{array}$ & $\begin{array}{l}56 \\
60 \\
66 \\
72 \\
70\end{array}$ & $\begin{array}{l}223 \\
256 \\
242 \\
217 \\
198\end{array}$ & $\begin{array}{l}167 \\
152 \\
146 \\
143 \\
135\end{array}$ & $\begin{array}{l}98 \\
93 \\
90 \\
88 \\
88\end{array}$ & $\begin{array}{r}65 \\
65 \\
72 \\
247 \\
65\end{array}$ & $\begin{array}{r}119 \\
95 \\
89 \\
83 \\
78\end{array}$ & $\begin{array}{l}65 \\
62 \\
59 \\
57 \\
54\end{array}$ \\
\hline $\begin{array}{l}16 \\
17 \\
18 \\
19 \\
20\end{array}$ & $\begin{array}{l}54 \\
52 \\
54 \\
54 \\
55\end{array}$ & $\begin{array}{r}54 \\
162 \\
94 \\
74 \\
66\end{array}$ & $\begin{array}{l}52 \\
50 \\
50 \\
50 \\
50\end{array}$ & $\begin{array}{l}38 \\
40 \\
44 \\
46 \\
48\end{array}$ & $\begin{array}{l}37 \\
38 \\
38 \\
38 \\
38\end{array}$ & $\begin{array}{r}68 \\
70 \\
180 \\
1132 \\
1015\end{array}$ & $\begin{array}{l}192 \\
185 \\
173 \\
173 \\
179\end{array}$ & $\begin{array}{l}129 \\
129 \\
135 \\
161 \\
132\end{array}$ & $\begin{array}{r}85 \\
82 \\
85 \\
85 \\
101\end{array}$ & $\begin{array}{l}67 \\
65 \\
62 \\
60 \\
60\end{array}$ & $\begin{array}{r}72 \\
168 \\
353 \\
125 \\
282\end{array}$ & $\begin{array}{l}54 \\
57 \\
57 \\
52 \\
57\end{array}$ \\
\hline $\begin{array}{l}21 \\
22 \\
23 \\
24 \\
25\end{array}$ & $\begin{array}{l}57 \\
55 \\
57 \\
59 \\
67\end{array}$ & $\begin{array}{l}62 \\
60 \\
66 \\
62 \\
58\end{array}$ & $\begin{array}{l}54 \\
48 \\
48 \\
46 \\
46\end{array}$ & $\begin{array}{l}50 \\
50 \\
48 \\
46 \\
46\end{array}$ & $\begin{array}{l}40 \\
40 \\
56 \\
50 \\
48\end{array}$ & $\begin{array}{r}657 \\
888 \\
1294 \\
948 \\
488\end{array}$ & $\begin{array}{l}173 \\
161 \\
155 \\
155 \\
167\end{array}$ & $\begin{array}{l}123 \\
123 \\
126 \\
118 \\
115\end{array}$ & $\begin{array}{l}88 \\
82 \\
82 \\
80 \\
77\end{array}$ & $\begin{array}{l}60 \\
77 \\
69 \\
65 \\
72\end{array}$ & $\begin{array}{r}144 \\
131 \\
119 \\
107 \\
98\end{array}$ & $\begin{array}{l}\mathbf{5 2} \\
50 \\
52 \\
52 \\
52\end{array}$ \\
\hline $\begin{array}{l}26 \\
27 \\
28 \\
29 \\
30 \\
31\end{array}$ & $\begin{array}{l}65 \\
61 \\
59 \\
57 \\
57 \\
57\end{array}$ & $\begin{array}{r}58 \\
58 \\
56 \\
58 \\
58 \\
--\end{array}$ & $\begin{array}{l}46 \\
44 \\
46 \\
46 \\
44 \\
44\end{array}$ & $\begin{array}{l}46 \\
44 \\
40 \\
37 \\
42 \\
38\end{array}$ & $\begin{array}{r}46 \\
46 \\
46 \\
--0 \\
-\infty-\end{array}$ & $\begin{array}{l}452 \\
364 \\
364 \\
643 \\
853 \\
594\end{array}$ & $\begin{array}{l}198 \\
179 \\
173 \\
173 \\
175 \\
--0\end{array}$ & $\begin{array}{l}118 \\
118 \\
112 \\
109 \\
109 \\
109\end{array}$ & $\begin{array}{r}77 \\
77 \\
80 \\
90 \\
88 \\
---\end{array}$ & $\begin{array}{l}65 \\
60 \\
60 \\
60 \\
90 \\
65\end{array}$ & $\begin{array}{r}92 \\
113 \\
98 \\
116 \\
89 \\
83\end{array}$ & $\begin{array}{r}47 \\
45 \\
43 \\
47 \\
43 \\
- \\
-\end{array}$ \\
\hline MEAN & 57 & 63 & 51 & 42 & 41 & 352 & 221 & 150 & 91 & 75 & 139 & 60 \\
\hline
\end{tabular}


Table 16. Total nitrite plus nitrate nitrogen for Steiner Branch, 1978 and 1979 water years, in pounds.

TOTAL NO2 - NO3 IN POUNDS, WATER YEAR OCTOBER 1977 TO SEPTEMBER 1978

\begin{tabular}{|c|c|c|c|c|c|c|c|c|c|c|c|c|}
\hline naY & OCT & NOV & DEC & JAN & FEA & MAR & APR & MAY & JUN & JUL & AUG & SEP \\
\hline $\begin{array}{l}1 \\
2 \\
3 \\
4 \\
5\end{array}$ & $\begin{array}{l}33.7 \\
32.7 \\
30.5 \\
30.5 \\
31.6\end{array}$ & $\begin{array}{l}33.7 \\
40.7 \\
36.8 \\
34.8 \\
33.7\end{array}$ & $\begin{array}{l}31.6 \\
30.5 \\
30.5 \\
29.4 \\
29.4\end{array}$ & $\begin{array}{l}31.7 \\
31.7 \\
31.7 \\
31.7 \\
31.7\end{array}$ & $\begin{array}{l}28.3 \\
28.3 \\
28.3 \\
28.3 \\
28.3\end{array}$ & $\begin{array}{l}11.2 \\
11.2 \\
12.1 \\
11.2 \\
11.2\end{array}$ & $\begin{array}{l}31.7 \\
32.8 \\
31.7 \\
31.7 \\
23.0\end{array}$ & $\begin{array}{l}27.3 \\
26.3 \\
26.3 \\
26.3 \\
26.3\end{array}$ & $\begin{array}{l}41.7 \\
39.4 \\
37.2 \\
36.1 \\
35.0\end{array}$ & $\begin{array}{r}195 \\
70.0 \\
52.0 \\
47.2 \\
43.0\end{array}$ & $\begin{array}{l}55.1 \\
49.6 \\
45.5 \\
43.0 \\
41.4\end{array}$ & $\begin{array}{l}39.8 \\
39.8 \\
39.8 \\
38.7 \\
37.9\end{array}$ \\
\hline $\begin{array}{r}6 \\
7 \\
8 \\
9 \\
10\end{array}$ & $\begin{array}{l}30.5 \\
30.5 \\
39.7 \\
36.8 \\
35.8\end{array}$ & $\begin{array}{l}34.8 \\
34.8 \\
34.8 \\
35.8 \\
34.8\end{array}$ & $\begin{array}{l}29.4 \\
29.4 \\
30.5 \\
31.6 \\
32.7\end{array}$ & $\begin{array}{l}30.6 \\
30.6 \\
30.6 \\
29.4 \\
29.4\end{array}$ & $\begin{array}{l}28.3 \\
28.3 \\
28.3 \\
28.3 \\
29.4\end{array}$ & $\begin{array}{l}11.2 \\
11.2 \\
11.2 \\
11.2 \\
12.1\end{array}$ & $\begin{array}{r}162 \\
85.0 \\
50.4 \\
40.8 \\
77.1\end{array}$ & $\begin{array}{l}25.2 \\
24.1 \\
28.4 \\
26.3 \\
24.2\end{array}$ & $\begin{array}{l}33.9 \\
33.9 \\
35.0 \\
31.7 \\
30.6\end{array}$ & $\begin{array}{r}288 \\
91.0 \\
67.2 \\
60.5 \\
51.2\end{array}$ & $\begin{array}{l}40.5 \\
40.5 \\
39.7 \\
38.8 \\
37.9\end{array}$ & $\begin{array}{l}37.9 \\
37.9 \\
36.9 \\
36.9 \\
36.9\end{array}$ \\
\hline $\begin{array}{l}11 \\
12 \\
13 \\
14 \\
15\end{array}$ & $\begin{array}{l}35.8 \\
34.9 \\
33.7 \\
32.7 \\
32.7\end{array}$ & $\begin{array}{l}33.7 \\
32.7 \\
31.6 \\
32.7 \\
32.7\end{array}$ & $\begin{array}{l}32.7 \\
33.7 \\
32.7 \\
32.7 \\
32.7\end{array}$ & $\begin{array}{l}29.4 \\
29.4 \\
29.4 \\
29.4 \\
29.4\end{array}$ & $\begin{array}{l}28.3 \\
29.4 \\
29.4 \\
29.4 \\
29.4\end{array}$ & $\begin{array}{l}13.0 \\
13.0 \\
13.0 \\
13.0 \\
13.0\end{array}$ & $\begin{array}{l}50.4 \\
39.7 \\
33.9 \\
29.5 \\
28.4\end{array}$ & $\begin{array}{l}24.2 \\
23.0 \\
695 \\
409 \\
222\end{array}$ & $\begin{array}{l}29.5 \\
28.4 \\
27.3 \\
27.3 \\
27.3\end{array}$ & $\begin{array}{l}46.4 \\
53.6 \\
50.4 \\
43.9 \\
41.4\end{array}$ & $\begin{array}{l}37.9 \\
37.1 \\
36.2 \\
36.2 \\
37.1\end{array}$ & $\begin{array}{l}36.9 \\
40.8 \\
61.3 \\
62.0 \\
46.2\end{array}$ \\
\hline $\begin{array}{l}16 \\
17 \\
18 \\
19 \\
20\end{array}$ & $\begin{array}{l}32.7 \\
31.6 \\
31.6 \\
31.6 \\
31.6\end{array}$ & $\begin{array}{l}32.7 \\
32.7 \\
31.6 \\
31.6 \\
31.6\end{array}$ & $\begin{array}{l}32.7 \\
32.7 \\
32.7 \\
32.7 \\
31.6\end{array}$ & $\begin{array}{l}29.4 \\
30.6 \\
30.6 \\
30.6 \\
30.6\end{array}$ & $\begin{array}{l}28.3 \\
28.3 \\
28.3 \\
28.3 \\
28.3\end{array}$ & $\begin{array}{l}13.0 \\
13.0 \\
13.0 \\
28.4 \\
71.0\end{array}$ & $\begin{array}{c}262 \\
25.1 \\
64.1 \\
44.4 \\
37.4\end{array}$ & $\begin{array}{r}138 \\
112 \\
94.3 \\
81.9 \\
74.6\end{array}$ & $\begin{array}{r}74.0 \\
707 \\
91.0 \\
78.0 \\
47.4\end{array}$ & $\begin{array}{c}42.2 \\
41.4 \\
39.7 \\
38.8 \\
365\end{array}$ & $\begin{array}{l}43.0 \\
37.1 \\
41.4 \\
51.2 \\
37.9\end{array}$ & $\begin{array}{l}42.6 \\
39.0 \\
210 \\
35.0 \\
109\end{array}$ \\
\hline $\begin{array}{l}21 \\
22 \\
23 \\
24 \\
25\end{array}$ & $\begin{array}{l}31.6 \\
30.5 \\
30.5 \\
31.6 \\
32.7\end{array}$ & $\begin{array}{l}31.6 \\
29.4 \\
29.4 \\
28.2 \\
28.2\end{array}$ & $\begin{array}{l}31.6 \\
31.6 \\
30.5 \\
30.5 \\
30.5\end{array}$ & $\begin{array}{l}30.6 \\
30.6 \\
30.6 \\
30.6 \\
30.6\end{array}$ & $\begin{array}{l}28.3 \\
28.3 \\
28.3 \\
28.3 \\
28.3\end{array}$ & $\begin{array}{l}161 \\
167 \\
85.0 \\
44.4 \\
32.8\end{array}$ & $\begin{array}{l}36.2 \\
32.8 \\
35.1 \\
33.9 \\
31.7\end{array}$ & $\begin{array}{l}67.3 \\
62.6 \\
65.0 \\
60.2 \\
55.5\end{array}$ & $\begin{array}{r}40.6 \\
35.0 \\
32.8 \\
31.7 \\
178\end{array}$ & $\begin{array}{l}151 \\
120 \\
94.4 \\
75.9 \\
68.7\end{array}$ & $\begin{array}{l}36.2 \\
36.2 \\
35.3 \\
34.4 \\
32.6\end{array}$ & $\begin{array}{l}62.8 \\
50.4 \\
46.2 \\
43.5 \\
41.7\end{array}$ \\
\hline $\begin{array}{l}26 \\
27 \\
28 \\
29 \\
30 \\
31\end{array}$ & $\begin{array}{l}32.7 \\
30.5 \\
30.5 \\
29.4 \\
29.4 \\
31.6\end{array}$ & $\begin{array}{r}28.2 \\
28.2 \\
29.4 \\
30.5 \\
31.6 \\
\ldots-\end{array}$ & $\begin{array}{l}30.5 \\
30.5 \\
30.5 \\
30.5 \\
31.6 \\
31.6\end{array}$ & $\begin{array}{l}30.6 \\
29.4 \\
28.3 \\
28.3 \\
28.3 \\
28.3\end{array}$ & $\begin{array}{r}28.3 \\
28.3 \\
28.3 \\
\ldots-3 \\
\ldots\end{array}$ & $\begin{array}{l}29.5 \\
31.7 \\
33.9 \\
30.6 \\
30.6 \\
33.9\end{array}$ & $\begin{array}{r}28.4 \\
27.3 \\
27.3 \\
27.3 \\
26.2 \\
.\end{array}$ & $\begin{array}{l}52.0 \\
60.2 \\
67.3 \\
53.2 \\
50.0 \\
45.1\end{array}$ & $\begin{array}{r}53.2 \\
38.3 \\
32.8 \\
30.6 \\
48.0 \\
-.-\end{array}$ & $\begin{array}{l}86.3 \\
65.7 \\
57.4 \\
55.1 \\
52.0 \\
80.8\end{array}$ & $\begin{array}{l}33.5 \\
40.5 \\
67.2 \\
45.5 \\
34.4 \\
32.6\end{array}$ & $\begin{array}{r}40.8 \\
39.8 \\
38.9 \\
38.9 \\
38.9 \\
\end{array}$ \\
\hline MEAN & 32.3 & 32.4 & 31.3 & 30.1 & 28.5 & 32.2 & 49.6 & 89.5 & 67.1 & 85.0 & 40.5 & 50.2 \\
\hline WTR & & & & $A X$ & 707 & & & & & & & \\
\hline
\end{tabular}

TOTAL NO2 + NO3 IN POUNDS, WATER YEAR OCTOBER 1977 TO SEPTEMBER 1979

\begin{tabular}{|c|c|c|c|c|c|c|c|c|c|c|c|c|}
\hline DAY & OCT & Nov & DEC & JAN & FEB & MAR & $A P R$ & MAY & JUN & JUL & AUG & SEP \\
\hline $\begin{array}{l}1 \\
2 \\
3 \\
4 \\
5\end{array}$ & $\begin{array}{l}43.4 \\
45.2 \\
48.6 \\
45.2 \\
50.2\end{array}$ & $\begin{array}{l}46.9 \\
46.9 \\
46.9 \\
46.9 \\
46.9\end{array}$ & $\begin{array}{l}45.2 \\
45.2 \\
48.6 \\
47.7 \\
46.9\end{array}$ & $\begin{array}{l}34.4 \\
31.4 \\
31.4 \\
28.6 \\
28.6\end{array}$ & $\begin{array}{l}31.4 \\
26.0 \\
28.6 \\
28.6 \\
28.6\end{array}$ & $\begin{array}{l}45.3 \\
45.3 \\
52.6 \\
59.9 \\
58.1\end{array}$ & $\begin{array}{l}276 \\
298 \\
231 \\
231 \\
209\end{array}$ & $\begin{array}{l}157 \\
186 \\
242 \\
206 \\
203\end{array}$ & $\begin{array}{l}107 \\
102 \\
102 \\
102 \\
105\end{array}$ & $\begin{array}{l}60.2 \\
60.2 \\
57.9 \\
63.4 \\
53.3\end{array}$ & $\begin{array}{r}48.5 \\
48.5 \\
55.6 \\
56.8 \\
1.33\end{array}$ & $\begin{array}{l}53.7 \\
52.9 \\
52.0 \\
56.0 \\
49.6\end{array}$ \\
\hline $\begin{array}{r}6 \\
7 \\
8 \\
9 \\
10\end{array}$ & $\begin{array}{l}47.7 \\
45.2 \\
45.2 \\
55.0 \\
53.5\end{array}$ & $\begin{array}{l}46.9 \\
45.2 \\
45.2 \\
45.2 \\
45.2\end{array}$ & $\begin{array}{l}45.2 \\
46.0 \\
45.2 \\
43.4 \\
42.5\end{array}$ & $\begin{array}{l}28.6 \\
28.6 \\
31.4 \\
31.4 \\
28.6\end{array}$ & $\begin{array}{l}31.4 \\
31.4 \\
28.6 \\
28.6 \\
28.6\end{array}$ & $\begin{array}{l}56.2 \\
58.1 \\
54.4 \\
52.6 \\
50.8\end{array}$ & $\begin{array}{l}231 \\
177 \\
181 \\
176 \\
158\end{array}$ & $\begin{array}{l}203 \\
197 \\
188 \\
174 \\
162\end{array}$ & $\begin{array}{l}96.7 \\
99.4 \\
99.4 \\
99.4 \\
121\end{array}$ & $\begin{array}{l}52.1 \\
52.1 \\
50.9 \\
50.9 \\
50.9\end{array}$ & $\begin{array}{l}46.0 \\
44.8 \\
44.8 \\
16 ! \\
159\end{array}$ & $\begin{array}{l}48.3 \\
50.4 \\
50.4 \\
49.6 \\
50.4\end{array}$ \\
\hline $\begin{array}{l}11 \\
12 \\
13 \\
14 \\
15\end{array}$ & $\begin{array}{l}50.2 \\
47.7 \\
46.0 \\
45.2 \\
46.0\end{array}$ & $\begin{array}{l}44.3 \\
43.4 \\
63.9 \\
51.9 \\
48.6\end{array}$ & $\begin{array}{l}44 \cdot 3 \\
45 \cdot 2 \\
44 \cdot 3 \\
44 \cdot 3 \\
44 \cdot 3\end{array}$ & $\begin{array}{l}26.0 \\
28.6 \\
34.4 \\
31.4 \\
31.4\end{array}$ & $\begin{array}{l}28.6 \\
28.6 \\
28.6 \\
28.6 \\
28.6\end{array}$ & $\begin{array}{l}52.6 \\
56.2 \\
61.8 \\
67.4 \\
65.6\end{array}$ & $\begin{array}{l}162 \\
183 \\
175 \\
158 \\
145\end{array}$ & $\begin{array}{l}165 \\
151 \\
145 \\
143 \\
134\end{array}$ & $\begin{array}{l}99.4 \\
94.1 \\
91.6 \\
89.0 \\
89.0\end{array}$ & $\begin{array}{l}50.9 \\
50.9 \\
54.04 \\
97.0 \\
44.0\end{array}$ & $\begin{array}{l}92.0 \\
65.9 \\
63.6 \\
61.4 \\
59.1\end{array}$ & $\begin{array}{l}47.9 \\
47.0 \\
46.2 \\
45.3 \\
44.4\end{array}$ \\
\hline $\begin{array}{l}16 \\
17 \\
18 \\
19 \\
20\end{array}$ & $\begin{array}{l}46.9 \\
46.0 \\
46.9 \\
46.9 \\
47.7\end{array}$ & $\begin{array}{l}46.9 \\
93.0 \\
68.0 \\
53.5 \\
50.2\end{array}$ & $\begin{array}{l}44.3 \\
43.4 \\
43.4 \\
43.4 \\
43.4\end{array}$ & $\begin{array}{l}28.6 \\
31.4 \\
37.4 \\
40.6 \\
44.0\end{array}$ & $\begin{array}{l}26.0 \\
28.6 \\
28.6 \\
28.6 \\
28.6\end{array}$ & $\begin{array}{l}63.7 \\
65.6 \\
98.0 \\
558 \\
729\end{array}$ & $\begin{array}{l}141 \\
137 \\
129 \\
129 \\
133\end{array}$ & $\begin{array}{l}129 \\
129 \\
134 \\
160 \\
132\end{array}$ & $\begin{array}{l}86.4 \\
83.9 \\
86.4 \\
86.4 \\
102\end{array}$ & $\begin{array}{l}52.1 \\
50.9 \\
49.7 \\
48.5 \\
48.5\end{array}$ & $\begin{array}{l}56.8 \\
90.0 \\
118 \\
76.0 \\
121\end{array}$ & $\begin{array}{l}44.4 \\
45.3 \\
45.3 \\
43.5 \\
45.3\end{array}$ \\
\hline $\begin{array}{l}21 \\
22 \\
23 \\
24 \\
25\end{array}$ & $\begin{array}{l}48.6 \\
47.7 \\
48.6 \\
49.4 \\
52.7\end{array}$ & $\begin{array}{l}48.6 \\
47.7 \\
50.2 \\
48.6 \\
46.9\end{array}$ & $\begin{array}{l}45.2 \\
42.5 \\
42.5 \\
41.6 \\
41.6\end{array}$ & $\begin{array}{l}47.5 \\
47.5 \\
44.0 \\
40.6 \\
40.6\end{array}$ & $\begin{array}{l}31.04 \\
31.4 \\
55.0 \\
47.5 \\
44.0\end{array}$ & $\begin{array}{l}469 \\
564 \\
774 \\
578 \\
418\end{array}$ & $\begin{array}{l}129 \\
120 \\
116 \\
116 \\
125\end{array}$ & $\begin{array}{l}123 \\
123 \\
126 \\
118 \\
115\end{array}$ & $\begin{array}{l}89.0 \\
83.9 \\
83.9 \\
81.9 \\
78.8\end{array}$ & $\begin{array}{l}48.5 \\
56.8 \\
49.7 \\
50.9 \\
54.4\end{array}$ & $\begin{array}{l}83.1 \\
85.2 \\
74.6 \\
70.3 \\
67.0\end{array}$ & $\begin{array}{l}43.5 \\
42.6 \\
43.5 \\
43.5 \\
43.5\end{array}$ \\
\hline $\begin{array}{l}26 \\
27 \\
28 \\
29 \\
30 \\
31\end{array}$ & $\begin{array}{l}51.9 \\
50.2 \\
49.4 \\
48.6 \\
48.6 \\
48.6\end{array}$ & $\begin{array}{l}46.9 \\
46.9 \\
46.0 \\
46.9 \\
46.9 \\
-. .9\end{array}$ & $\begin{array}{l}41.6 \\
40.7 \\
41.6 \\
41.6 \\
40.7 \\
40.7\end{array}$ & $\begin{array}{l}40.6 \\
37.4 \\
31.4 \\
26.0 \\
34.3 \\
28.6\end{array}$ & $\begin{array}{r}40.6 \\
40.6 \\
40.6 \\
\ldots \\
\ldots\end{array}$ & $\begin{array}{l}276 \\
231 \\
231 \\
368 \\
463 \\
345\end{array}$ & $\begin{array}{c}145 \\
133 \\
129 \\
129 \\
129 \\
-\end{array}$ & $\begin{array}{l}118 \\
118 \\
113 \\
110 \\
110 \\
110\end{array}$ & $\begin{array}{r}78.8 \\
78.8 \\
81.3 \\
91.6 \\
89.0 \\
\ldots .-\end{array}$ & $\begin{array}{l}50.9 \\
48.5 \\
48.5 \\
62.5 \\
50.9 \\
91.6\end{array}$ & $\begin{array}{l}64.8 \\
72.5 \\
67.0 \\
73.5 \\
63.6 \\
61.4\end{array}$ & $\begin{array}{r}41.7 \\
40.8 \\
39.8 \\
41.7 \\
39.8 \\
-\ldots\end{array}$ \\
\hline MEAN & 48.2 & 50.0 & 43.8 & 34.0 & 32.4 & 228 & 164 & 149 & 92.6 & 55.2 & 76.9 & 46.3 \\
\hline
\end{tabular}


Table 17. Total ammonia nitrogen for Steiner Branch, 1978 and 1979 water years, in pounds.

TOTAL AMMONIA NITROGEN IN PRUNOS, WATER YEAR OCTOBER 1977 IO SEPTEMBER 2978

\begin{tabular}{|c|c|c|c|c|c|c|c|c|c|c|c|c|}
\hline$\partial \Delta Y$ & OCT & nuv & DEC & JAN & FER & MAR & $\triangle P R$ & MAY & JUN & JUL & AUG & SEP \\
\hline $\begin{array}{l}1 \\
2 \\
3 \\
4 \\
5\end{array}$ & $\begin{array}{l}1 \\
01 \\
01 \\
01 \\
01\end{array}$ & $\begin{array}{l}11 \\
: 1 \\
: 1 \\
: 1 \\
: 1\end{array}$ & $\begin{array}{l}: 2 \\
: 2 \\
: 2 \\
: 2 \\
: 2 \\
: 2\end{array}$ & $\begin{array}{l}.3 \\
: 3 \\
: 3 \\
: 3\end{array}$ & $\begin{array}{l}.3 \\
: 3 \\
: 3 \\
: 3 \\
.3\end{array}$ & $\begin{array}{l}.4 \\
.44 \\
.44 \\
.4\end{array}$ & $\begin{array}{l}.7 \\
: 7 \\
.7 \\
.7\end{array}$ & $\begin{array}{l}.3 \\
: 3 \\
: 3 \\
: 3 \\
.3\end{array}$ & $\begin{array}{l}.9 \\
.8 \\
.7 \\
.7\end{array}$ & $\begin{array}{r}42 \\
4.8 \\
1.3 \\
.7 \\
.4\end{array}$ & $\begin{array}{l}1.7 \\
.9 \\
.6 \\
.4\end{array}$ & $\begin{array}{l}1 \\
: 1 \\
: 1 \\
: 1 \\
: 1\end{array}$ \\
\hline $\begin{array}{r}6 \\
7 \\
8 \\
9 \\
10\end{array}$ & $\begin{array}{l}11 \\
: 1 \\
11 \\
11 \\
1\end{array}$ & $\begin{array}{l}1 \\
: 1 \\
: 11 \\
: 1 \\
: 1\end{array}$ & $\begin{array}{l}.2 \\
: 2 \\
: 2 \\
: 2 \\
.2 \\
.2\end{array}$ & $\begin{array}{l}.3 \\
: 3 \\
: 3 \\
.3\end{array}$ & $\begin{array}{l}.3 \\
: 3 \\
: 3 \\
.3 \\
.3\end{array}$ & $\begin{array}{l}.4 \\
.44 \\
.4 \\
.4\end{array}$ & $\begin{array}{r}19 \\
\mathbf{9 . 0} \\
\mathbf{3 . 4} \\
1.0 \\
\mathbf{9 . 0}\end{array}$ & $\begin{array}{l}.2 \\
: 2 \\
: 4 \\
: 3 \\
: 2\end{array}$ & $\begin{array}{l}.6 \\
.6 \\
.6 \\
.5 \\
.5\end{array}$ & $\begin{array}{r}42 \\
8.8 \\
5.3 \\
2.9 \\
1.1\end{array}$ & $\begin{array}{l}: 3 \\
: 3 \\
: 3 \\
: \frac{3}{2} \\
: 2\end{array}$ & $\begin{array}{l}: 1 \\
: 1 \\
: 11 \\
01\end{array}$ \\
\hline $\begin{array}{l}11 \\
12 \\
13 \\
14 \\
15\end{array}$ & $\begin{array}{l}1 \\
01 \\
11 \\
01 \\
01\end{array}$ & $\begin{array}{l}: 1 \\
: 1 \\
: 1 \\
: 1 \\
11\end{array}$ & $\begin{array}{l}: 2 \\
: 2 \\
: 2 \\
: 2 \\
: 2 \\
: 2 \\
: 2\end{array}$ & $\begin{array}{l}.3 \\
: 3 \\
: 3 \\
: 3 \\
.3\end{array}$ & $\begin{array}{l}.3 \\
.3 \\
.3 \\
.3 \\
.3\end{array}$ & $\begin{array}{l}.5 \\
.5 \\
.5 \\
.5 \\
.5\end{array}$ & $\begin{array}{r}3.4 \\
1.5 \\
.9 \\
.5 \\
.5\end{array}$ & $\begin{array}{c}1.2 \\
263 \\
45 \\
12 \\
12\end{array}$ & $\begin{array}{r}.5 \\
.4 \\
.4 \\
.4 \\
.4\end{array}$ & $\begin{array}{r}.6 \\
1.4 \\
1.0 \\
.5 \\
.3\end{array}$ & $\begin{array}{l}: 2 \\
: 2 \\
: 2 \\
: 2 \\
: 2 \\
: 2\end{array}$ & $\begin{array}{r}: 1 \\
: 1 \\
1.3 \\
1.4 \\
: 0\end{array}$ \\
\hline $\begin{array}{l}16 \\
17 \\
18 \\
19 \\
20\end{array}$ & $\begin{array}{l}1 \\
01 \\
011 \\
01 \\
01\end{array}$ & $\begin{array}{l}: 1 \\
: 1 \\
: 1 \\
: 1 \\
: 1\end{array}$ & $\begin{array}{l}: 2 \\
: 2 \\
: 2 \\
: 2 \\
: 2 \\
: 2\end{array}$ & $\begin{array}{l}.3 \\
: 3 \\
: 3 \\
: 3\end{array}$ & $\begin{array}{l}.3 \\
: 3 \\
.3 \\
.3 \\
.3\end{array}$ & $\begin{array}{r}.5 \\
0.5 \\
.5 \\
9.6 \\
9.8\end{array}$ & $\begin{array}{l}.4 \\
7.3 \\
2.7 \\
2.2 \\
1.2\end{array}$ & $\begin{array}{l}7.6 \\
5.2 \\
3.8 \\
3.00 \\
2.05\end{array}$ & $\begin{array}{r}18 \\
278 \\
14 \\
4.7 \\
1.2\end{array}$ & 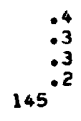 & $\begin{array}{r}: 4 \\
: 2 \\
: 3 \\
::_{1}^{4} \\
: 0\end{array}$ & $\begin{array}{l}2.1 \\
79.5 \\
2.8 \\
16\end{array}$ \\
\hline $\begin{array}{l}21 \\
22 \\
23 \\
23 \\
24 \\
75\end{array}$ & $\begin{array}{l}1 \\
11 \\
11 \\
01 \\
0\end{array}$ & $\begin{array}{l}: 1 \\
: 1 \\
: 1 \\
: 1 \\
: 1\end{array}$ & $\begin{array}{l}: 2 \\
: 2 \\
: 2 \\
: 2 \\
: 2 \\
.2\end{array}$ & $\begin{array}{l}.3 \\
: 3 \\
: 3 \\
: 3 \\
.3\end{array}$ & $\begin{array}{l}.3 \\
: 3 \\
: 3 \\
: 3 \\
.3\end{array}$ & $\begin{array}{l}49 \\
28 \\
14 \\
2.2 \\
.8\end{array}$ & $\begin{array}{r}1.1 \\
07 \\
1.0 \\
.9\end{array}$ & $\begin{array}{l}2.1 \\
1.8 \\
1.99 \\
1.7 \\
1.5\end{array}$ & $\begin{array}{r}0^{5} \\
: 1 \\
0.1 \\
25\end{array}$ & $\begin{array}{c}35 \\
22 \\
15 \\
10 \\
5.9\end{array}$ & $\begin{array}{l}: 2 \\
\because 2 \\
: 1 \\
: 1\end{array}$ & $\begin{array}{r}5.4 \\
: 7 \\
.2 \\
.2 \\
.2\end{array}$ \\
\hline $\begin{array}{l}26 \\
27 \\
28 \\
79 \\
30 \\
31\end{array}$ & $\begin{array}{l}: 1 \\
: 1 \\
: 1 \\
: 1 \\
: 1\end{array}$ & $\begin{array}{c}: 1 \\
: 1 \\
: 1 \\
: 1 \\
\therefore 1\end{array}$ & $\begin{array}{l}.2 \\
.2 \\
: 2 \\
.2 \\
.2 \\
.2\end{array}$ & $\begin{array}{l}.3 \\
: 3 \\
.3 \\
.2 \\
.2 \\
.2\end{array}$ & $\begin{array}{r}\quad 3 \\
: 3 \\
\therefore 3 \\
\hdashline-: \\
\hdashline-:\end{array}$ & $\begin{array}{l}.5 \\
.7 \\
.9 \\
.6 \\
.9\end{array}$ & $\begin{array}{r}.5 \\
.4 \\
.4 \\
.4 \\
-.4\end{array}$ & $\begin{array}{l}1.5 \\
1.7 \\
2.1 \\
11.4 \\
1.2 \\
1.0\end{array}$ & $\begin{array}{r}2.5 \\
\quad .3 \\
.1 \\
.11 \\
4.6 \\
\hdashline-.\end{array}$ & $\begin{array}{c}13 \\
4.6 \\
2.1 \\
1.7 \\
1.2 \\
11\end{array}$ & $\begin{array}{r}: 1 \\
: 3 \\
5: 3 \\
: 6 \\
: 1 \\
: 1\end{array}$ & $\begin{array}{r}.2 \\
.2 \\
.2 \\
.2 \\
: 2 \\
-2\end{array}$ \\
\hline MFAN & .1 & .1 & .2 & .3 & .3 & 3.8 & 2.4 & 12 & 12 & 12 & .5 & 3.7 \\
\hline & & & & $x$ & 278 & & & & & & & \\
\hline
\end{tabular}

TOTAL AMMONIA NITROGEN IN POUNDS, WATER YEAR OCTOBER 1970 TO SEPTEMBER 1979

\begin{tabular}{|c|c|c|c|c|c|c|c|c|c|c|c|c|}
\hline DAY & OCT & NOV & DEC & JAN & FEB & MAR & $A P Q$ & mar & JUN & JUL & AUG & SEP \\
\hline $\begin{array}{l}1 \\
2 \\
3 \\
4 \\
5\end{array}$ & $\begin{array}{l}.7 \\
.2 \\
.4 \\
.2 \\
.7\end{array}$ & $\begin{array}{l}.3 \\
.3 \\
.3 \\
.3 \\
.3\end{array}$ & $\begin{array}{l}.4 \\
.4 \\
.7 \\
.6 \\
.5\end{array}$ & $\begin{array}{l}.3 \\
.2 \\
.2 \\
.2 \\
.2\end{array}$ & $\begin{array}{l}.3 \\
. ? \\
.2 \\
.2 \\
.2\end{array}$ & $\begin{array}{r}.8 \\
.8 \\
1.4 \\
2.1 \\
1.9\end{array}$ & $\begin{array}{l}5.2 \\
6.6 \\
3.0 \\
3.0 \\
2.2\end{array}$ & $\begin{array}{r}.3 \\
1.7 \\
3.9 \\
2.4 \\
2.3\end{array}$ & $\begin{array}{r}.3 \\
.3 \\
.3 \\
.3 \\
1.0\end{array}$ & $\begin{array}{l}.6 \\
.6 \\
.5 \\
.7 \\
.3\end{array}$ & $\begin{array}{l}.4 \\
1.4 \\
1.5 \\
25\end{array}$ & $\begin{array}{r}: 9 \\
: 9 \\
1.9 \\
.0\end{array}$ \\
\hline $\begin{array}{r}6 \\
7 \\
8 \\
9 \\
10\end{array}$ & $\begin{array}{r}.3 \\
.2 \\
.2 \\
2.1 \\
1.5\end{array}$ & $\begin{array}{l}.3 \\
.2 \\
.2 \\
.2 \\
.2\end{array}$ & $\begin{array}{l}.4 \\
.5 \\
.4 \\
.3 \\
.3\end{array}$ & $\begin{array}{l}.2 \\
.2 \\
.2 \\
.2 \\
.2\end{array}$ & $\begin{array}{l}.3 \\
.3 \\
.3 \\
.2 \\
.2\end{array}$ & $\begin{array}{l}1.7 \\
1.9 \\
1.5 \\
1.4 \\
1.2\end{array}$ & $\begin{array}{l}3.0 \\
1.3 \\
1.4 \\
1.2 \\
.9\end{array}$ & $\begin{array}{l}2.3 \\
2.1 \\
1.8 \\
1.4 \\
1.2\end{array}$ & $\begin{array}{r}.7 \\
.8 \\
.8 \\
.8 \\
1.5\end{array}$ & $\begin{array}{l}.3 \\
.3 \\
.3 \\
.3 \\
.3\end{array}$ & $\begin{array}{l}3.1 \\
2.0 \\
2.0 \\
27 \\
20\end{array}$ & $\begin{array}{l}.8 \\
.8 \\
.8 \\
.8 \\
.8\end{array}$ \\
\hline $\begin{array}{l}11 \\
12 \\
13 \\
14 \\
15\end{array}$ & $\begin{array}{l}. ? \\
.3 \\
.2 \\
.2 \\
.2\end{array}$ & $\begin{array}{r}.2 \\
.2 \\
5.6 \\
1.0 \\
.4\end{array}$ & $\begin{array}{l}.4 \\
.4 \\
.4 \\
.4 \\
.4\end{array}$ & $\begin{array}{l}.2 \\
.2 \\
.3 \\
.2 \\
.2\end{array}$ & $\begin{array}{l}.2 \\
.2 \\
.2 \\
.2 \\
.2\end{array}$ & $\begin{array}{l}1.4 \\
1.7 \\
2.4 \\
3.2 \\
2.9\end{array}$ & $\begin{array}{r}.9 \\
1.4 \\
1.2 \\
.9 \\
.7\end{array}$ & $\begin{array}{r}1.2 \\
.9 \\
.8 \\
.8 \\
.7\end{array}$ & $\begin{array}{l}.8 \\
.7 \\
.7 \\
.6 \\
.6\end{array}$ & $\begin{array}{r}.3 \\
15^{.3} \\
2.3\end{array}$ & $\begin{array}{l}3.1 \\
1.1 \\
.8 \\
.6 \\
.4\end{array}$ & $\begin{array}{l}.8 \\
.7 \\
.7 \\
.7 \\
.7\end{array}$ \\
\hline $\begin{array}{l}16 \\
17 \\
18 \\
19 \\
20\end{array}$ & $\begin{array}{l}.3 \\
.2 \\
.3 \\
.3 \\
.3\end{array}$ & $\begin{array}{r}.3 \\
8.3 \\
3.2 \\
1.4 \\
.9\end{array}$ & $\begin{array}{l}.4 \\
.3 \\
.3 \\
.3 \\
.3\end{array}$ & $\begin{array}{l}.2 \\
.2 \\
.3 \\
.4 \\
.4\end{array}$ & $\begin{array}{l}.2 \\
.2 \\
.2 \\
.2 \\
.2\end{array}$ & $\begin{array}{l}2.6 \\
2.9 \\
11 \\
95 \\
61\end{array}$ & $\begin{array}{l}.6 \\
.6 \\
.5 \\
.5 \\
.5\end{array}$ & $\begin{array}{r}.6 \\
.6 \\
.7 \\
1.1 \\
.6\end{array}$ & $\begin{array}{l}.6 \\
.5 \\
.6 \\
.6 \\
.9\end{array}$ & $\begin{array}{l}.8 \\
.7 \\
.5 \\
.4 \\
.4\end{array}$ & $\begin{array}{l}6.3 \\
22 \\
19^{.6}\end{array}$ & $\begin{array}{l}.7 \\
.7 \\
.7 \\
.7 \\
.7\end{array}$ \\
\hline $\begin{array}{l}21 \\
22 \\
23 \\
24 \\
25\end{array}$ & $\begin{array}{r}.4 \\
.3 \\
.4 \\
.5 \\
1.2\end{array}$ & $\begin{array}{r}.7 \\
1.6 \\
.7 \\
.5\end{array}$ & $\begin{array}{l}.4 \\
.3 \\
.3 \\
.2 \\
.2\end{array}$ & $\begin{array}{l}.5 \\
.5 \\
.4 \\
.4 \\
.4\end{array}$ & $\begin{array}{l}.3 \\
.3 \\
.9 \\
.6 \\
.6\end{array}$ & $\begin{array}{r}28 \\
60 \\
109 \\
76 \\
14\end{array}$ & $\begin{array}{l}.5 \\
.4 \\
.3 \\
.3 \\
.4\end{array}$ & $\begin{array}{l}.5 \\
.5 \\
.5 \\
.4 \\
.4\end{array}$ & $\begin{array}{l}.6 \\
.5 \\
.5 \\
.5 \\
.4\end{array}$ & $\begin{array}{r}.4 \\
1.8 \\
.5 \\
.7 \\
1.2\end{array}$ & $\begin{array}{l}1.2 \\
1.4 \\
1.2 \\
1.0 \\
1.0\end{array}$ & $\begin{array}{l}.7 \\
.6 \\
.7 \\
.7 \\
.7\end{array}$ \\
\hline $\begin{array}{l}26 \\
27 \\
28 \\
29 \\
30 \\
31\end{array}$ & $\begin{array}{r}1.0 \\
.7 \\
.5 \\
.4 \\
.4 \\
.4\end{array}$ & $\begin{array}{r}.5 \\
.5 \\
.5 \\
.5 \\
.5 \\
-. .\end{array}$ & $\begin{array}{l}.2 \\
.2 \\
.2 \\
.2 \\
.2 \\
.2\end{array}$ & $\begin{array}{l}.4 \\
.3 \\
.2 \\
.2 \\
.3 \\
.2\end{array}$ & $\begin{array}{r}.5 \\
.5 \\
.5 \\
-.-0 \\
-.--\end{array}$ & $\begin{array}{l}5.2 \\
3.0 \\
3.0 \\
13 \\
26 \\
10\end{array}$ & $\begin{array}{r}.7 \\
.5 \\
.5 \\
.4 \\
.4 \\
-.-\end{array}$ & $\begin{array}{l}.4 \\
.4 \\
.4 \\
.4 \\
.4 \\
.4\end{array}$ & $\begin{array}{r}.4 \\
.4 \\
.5 \\
.7 \\
.6 \\
-.0\end{array}$ & $\begin{array}{r}.7 \\
.4 \\
.4 \\
.4 \\
4.4 \\
.7\end{array}$ & $\begin{array}{r}1.0 \\
1.1 \\
1.0 \\
1.1 \\
1.0 \\
.9\end{array}$ & $\begin{array}{r}.6 \\
.6 \\
.6 \\
.6 \\
.6\end{array}$ \\
\hline MEAN & .5 & 1.0 & .4 & .3 & .3 & 18 & 1.3 & 1.0 & .6 & 1.2 & 4.8 & .7 \\
\hline WTR Y & & & & $\max$ & 109 & & & & & & & \\
\hline
\end{tabular}


Table 18. Total phosphorus for Steiner Branch, 1978 and 1979 water years, in pounds per day.

TOTAL PHOSPHORUS IN PUUNDS PER DAY, WATER YEAR OCTORER 1977 TO SEPIEMBER 1978

\begin{tabular}{|c|c|c|c|c|c|c|c|c|c|c|c|c|}
\hline naY & UC $T$ & iNov & NEC & JAIV & FEH & MAK & $\triangle P_{K}$ & MAY & JUN & JUL & AUG & SEP \\
\hline $\begin{array}{l}1 \\
2 \\
3 \\
4 \\
5\end{array}$ & $\begin{array}{l}.50 \\
.50 \\
.50 \\
.50 \\
.50\end{array}$ & $\begin{array}{l}.50 \\
.70 \\
.60 \\
.50 \\
.50\end{array}$ & $\begin{array}{l}.50 \\
.50 \\
.50 \\
.40 \\
.40\end{array}$ & $\begin{array}{l}.50 \\
.50 \\
.50 \\
.50 \\
.50\end{array}$ & $\begin{array}{l}.47 \\
.40 \\
.40 \\
.40 \\
.40\end{array}$ & $\begin{array}{l}.40 \\
.40 \\
.40 \\
.40 \\
.40\end{array}$ & $\begin{array}{l}2.60 \\
2.80 \\
2.60 \\
2.60 \\
2.30\end{array}$ & $\begin{array}{l}.60 \\
.50 \\
.50 \\
.50 \\
.50\end{array}$ & $\begin{array}{l}1.10 \\
.90 \\
.80 \\
.80 \\
.70\end{array}$ & $\begin{array}{r}194 \\
9.6 \\
2.6 \\
1.8 \\
1.4\end{array}$ & $\begin{array}{l}2.00 \\
1.50 \\
1.20 \\
1.00 \\
.90\end{array}$ & $\begin{array}{l}.40 \\
.40 \\
.40 \\
.30 \\
.30\end{array}$ \\
\hline $\begin{array}{r}6 \\
7 \\
8 \\
9 \\
10\end{array}$ & $\begin{array}{l}.50 \\
.50 \\
.70 \\
.50 \\
.60\end{array}$ & $\begin{array}{l}.60 \\
.60 \\
.60 \\
.60 \\
.60\end{array}$ & $\begin{array}{l}.40 \\
.40 \\
.50 \\
.50 \\
.50\end{array}$ & $\begin{array}{l}.50 \\
.50 \\
.50 \\
.40 \\
.40\end{array}$ & $\begin{array}{l}.40 \\
.40 \\
.40 \\
.40 \\
.40\end{array}$ & $\begin{array}{l}.40 \\
.40 \\
.40 \\
.40 \\
.40\end{array}$ & $\begin{array}{r}22.00 \\
4.80 \\
2.20 \\
1.50 \\
4.40\end{array}$ & $\begin{array}{l}.50 \\
.50 \\
.60 \\
.50 \\
.50\end{array}$ & $\begin{array}{l}.70 \\
.10 \\
.70 \\
.60 \\
.60\end{array}$ & $\begin{array}{l}291 \\
13 \\
5.5 \\
4.0 \\
2.4\end{array}$ & $\begin{array}{l}.80 \\
.80 \\
.80 \\
.70 \\
.70\end{array}$ & $\begin{array}{l}.30 \\
.30 \\
.30 \\
.30 \\
.30\end{array}$ \\
\hline $\begin{array}{l}11 \\
12 \\
13 \\
14 \\
15\end{array}$ & $\begin{array}{l}.60 \\
.60 \\
.50 \\
.50 \\
.50\end{array}$ & $\begin{array}{l}.50 \\
.50 \\
.50 \\
.50 \\
.50\end{array}$ & $\begin{array}{l}.50 \\
.50 \\
.50 \\
.50 \\
.50\end{array}$ & $\begin{array}{l}.40 \\
.40 \\
.40 \\
.40 \\
.40\end{array}$ & $\begin{array}{l}.40 \\
.40 \\
.40 \\
.40 \\
.40\end{array}$ & $\begin{array}{l}.50 \\
.50 \\
.50 \\
.50 \\
.50\end{array}$ & $\begin{array}{l}2.20 \\
1.40 \\
1.00 \\
.80 \\
.70\end{array}$ & $\begin{array}{r}.50 \\
11.00 \\
403.00 \\
62.00 \\
12.00\end{array}$ & $\begin{array}{l}.50 \\
.50 \\
.50 \\
.50 \\
.50\end{array}$ & $\begin{array}{l}1.7 \\
2.7 \\
2.2 \\
1.5 \\
1.2\end{array}$ & $\begin{array}{l}.70 \\
.60 \\
.60 \\
.60 \\
.60\end{array}$ & $\begin{array}{r}.30 \\
.40 \\
9.00 \\
2.00 \\
.60\end{array}$ \\
\hline $\begin{array}{l}16 \\
17 \\
18 \\
19 \\
20\end{array}$ & $\begin{array}{l}.50 \\
.50 \\
.50 \\
.50 \\
.50\end{array}$ & $\begin{array}{l}.50 \\
.50 \\
.50 \\
.50 \\
.50\end{array}$ & $\begin{array}{l}.50 \\
.50 \\
.50 \\
.50 \\
.50\end{array}$ & $\begin{array}{l}.40 \\
.50 \\
.50 \\
.50 \\
.50\end{array}$ & $\begin{array}{l}.40 \\
.40 \\
.40 \\
.40 \\
.40\end{array}$ & $\begin{array}{r}.50 \\
.50 \\
.50 \\
2.20 \\
8.00\end{array}$ & $\begin{array}{l}.60 \\
.60 \\
3.40 \\
1.70 \\
1.20\end{array}$ & $\begin{array}{l}9.10 \\
6.20 \\
4.50 \\
3.50 \\
2.90\end{array}$ & $\begin{array}{r}54.00 \\
962.0 \\
12.00 \\
3.70 \\
2.00\end{array}$ & $\begin{array}{r}1.3 \\
1.2 \\
1.1 \\
1.0 \\
1300^{2}\end{array}$ & $\begin{array}{r}3.00 \\
.60 \\
.90 \\
.80 \\
.70\end{array}$ & $\begin{array}{r}.50 \\
2.10 \\
200.0 \\
1.60 \\
22.00\end{array}$ \\
\hline $\begin{array}{l}21 \\
22 \\
23 \\
24 \\
25\end{array}$ & $\begin{array}{l}.50 \\
.50 \\
.50 \\
.50 \\
.50\end{array}$ & $\begin{array}{l}.50 \\
.40 \\
.40 \\
.40 \\
.40\end{array}$ & $\begin{array}{r}.50 \\
.50 \\
.50 \\
.50 \\
.50\end{array}$ & $\begin{array}{l}.50 \\
.50 \\
.50 \\
.50 \\
.50\end{array}$ & $\begin{array}{l}.40 \\
.40 \\
.40 \\
.40 \\
.40\end{array}$ & $\begin{array}{r}60.00 \\
31.00 \\
11.00 \\
4.50 \\
2.80\end{array}$ & $\begin{array}{l}1.20 \\
1.00 \\
1.10 \\
1.00 \\
.90\end{array}$ & $\begin{array}{l}2.4 n \\
2.10 \\
2.30 \\
2.00 \\
1.70\end{array}$ & $\begin{array}{r}1.50 \\
1.10 \\
.90 \\
.90 \\
15.00\end{array}$ & $\begin{array}{l}28 \\
21 \\
10 \\
5.3 \\
3.9\end{array}$ & $\begin{array}{l}.60 \\
.60 \\
.60 \\
.50 \\
.40\end{array}$ & $\begin{array}{l}4.00 \\
2.00 \\
1.80 \\
1.60 \\
1.40\end{array}$ \\
\hline $\begin{array}{l}26 \\
27 \\
28 \\
29 \\
30 \\
31\end{array}$ & $\begin{array}{l}.50 \\
.50 \\
.50 \\
.40 \\
.40 \\
.50\end{array}$ & $\begin{array}{l}.40 \\
.40 \\
.40 \\
.50 \\
.50 \\
.-\end{array}$ & $\begin{array}{l}.50 \\
.50 \\
.50 \\
.50 \\
.50 \\
.50\end{array}$ & $\begin{array}{l}.50 \\
.40 \\
.40 \\
.40 \\
.40 \\
.40\end{array}$ & $\begin{array}{l}.40 \\
.40 \\
.40 \\
-\infty \\
-\infty\end{array}$ & $\begin{array}{l}2.30 \\
2.50 \\
2.90 \\
2.50 \\
2.60 \\
2.90\end{array}$ & $\begin{array}{l}.70 \\
.10 \\
.70 \\
.70 \\
.60 \\
.00\end{array}$ & $\begin{array}{l}1.50 \\
2.00 \\
2.40 \\
1.50 \\
1.40 \\
1.20\end{array}$ & $\begin{array}{r}2.60 \\
1.30 \\
.90 \\
.80 \\
7.70 \\
-.0\end{array}$ & $\begin{array}{c}30 \\
3.5 \\
2.3 \\
2.1 \\
1.7 \\
25\end{array}$ & $\begin{array}{r}.50 \\
.80 \\
16.00 \\
1.20 \\
.50 \\
.40\end{array}$ & $\begin{array}{l}1.30 \\
1.30 \\
1.20 \\
1.10 \\
1.10 \\
-. .0\end{array}$ \\
\hline $\begin{array}{l}\text { MAX } \\
\text { MIN }\end{array}$ & $\begin{array}{r}.70 \\
.40\end{array}$ & $\begin{array}{l}.70 \\
.40\end{array}$ & $\begin{array}{r}.50 \\
.40\end{array}$ & $\begin{array}{r}.50 \\
.40\end{array}$ & $\begin{array}{r}.40 \\
.40\end{array}$ & $\begin{array}{r}60 \\
.40\end{array}$ & $\begin{array}{r}22 \\
.60\end{array}$ & $\begin{array}{r}403 \\
.50\end{array}$ & $\begin{array}{r}962 \\
.50\end{array}$ & $\begin{array}{r}1300 \\
1.0\end{array}$ & $\begin{array}{r}16 \\
.40\end{array}$ & $\begin{array}{l}200 \\
.30\end{array}$ \\
\hline
\end{tabular}

TOTAL PHOSPHORUS IN POUNDS DER DAY, WATER YEAR OCTORER 1978 TO SEPTEMBER 1979

\begin{tabular}{|c|c|c|c|c|c|c|c|c|c|c|c|c|}
\hline DAY & OCT & NOV & DEC & JAN & FEA & MAR & APR & HAY & JUN & JUL & AUG & SEP \\
\hline $\begin{array}{l}1 \\
2 \\
3 \\
4 \\
5\end{array}$ & $\begin{array}{l}.90 \\
1.00 \\
1.30 \\
1.00 \\
1.50\end{array}$ & $\begin{array}{l}1.20 \\
1.20 \\
1.20 \\
1.20 \\
1.20\end{array}$ & $\begin{array}{l}.50 \\
.50 \\
.70 \\
.60 \\
.60\end{array}$ & $\begin{array}{l}.20 \\
.20 \\
.20 \\
.20 \\
.20\end{array}$ & $\begin{array}{l}.20 \\
.20 \\
.20 \\
.20 \\
.20\end{array}$ & $\begin{array}{l}.30 \\
.30 \\
.50 \\
.80 \\
.70\end{array}$ & $\begin{array}{r}9.1 \\
11 \\
6.0 \\
6.0 \\
4.8\end{array}$ & $\begin{array}{l}1.2 \\
1.8 \\
4.7 \\
3.4 \\
3.4\end{array}$ & $\begin{array}{r}1.00 \\
.90 \\
.90 \\
.90 \\
.90\end{array}$ & $\begin{array}{l}.60 \\
.60 \\
.60 \\
.80 \\
.40\end{array}$ & $\begin{array}{r}.90 \\
.90 \\
1.60 \\
1.70 \\
79.00\end{array}$ & $\begin{array}{l}4.9 \\
4.6 \\
4.3 \\
5.6 \\
3.7\end{array}$ \\
\hline $\begin{array}{r}6 \\
7 \\
8 \\
9 \\
10\end{array}$ & $\begin{array}{l}1.20 \\
1.00 \\
1.00 \\
2.00 \\
1.80\end{array}$ & $\begin{array}{l}1.20 \\
1.00 \\
1.00 \\
1.00 \\
1.00\end{array}$ & $\begin{array}{l}.50 \\
.50 \\
.50 \\
.41 \\
.30\end{array}$ & $\begin{array}{l}.20 \\
.20 \\
.20 \\
.20 \\
.20\end{array}$ & $\begin{array}{l}.20 \\
.20 \\
.20 \\
.20 \\
.20\end{array}$ & $\begin{array}{l}.60 \\
.70 \\
.80 \\
.50 \\
.50\end{array}$ & $\begin{array}{l}6.0 \\
3.5 \\
3.4 \\
3.0 \\
2.4\end{array}$ & $\begin{array}{l}3.4 \\
3.2 \\
2.9 \\
2.5 \\
2.2\end{array}$ & $\begin{array}{r}1.20 \\
.80 \\
.80 \\
.80 \\
1.20\end{array}$ & $\begin{array}{l}.80 \\
.80 \\
.70 \\
.70 \\
.70\end{array}$ & $\begin{array}{r}7.20 \\
2.00 \\
2.00 \\
40.00 \\
55.00\end{array}$ & $\begin{array}{l}3.4 \\
3.9 \\
3.9 \\
3.7 \\
3.9\end{array}$ \\
\hline $\begin{array}{l}11 \\
12 \\
13 \\
14 \\
15\end{array}$ & $\begin{array}{l}.80 \\
1.20 \\
1.10 \\
1.00 \\
1.10\end{array}$ & $\begin{array}{l}1.00 \\
.90 \\
3.30 \\
1.60 \\
1.30\end{array}$ & $\begin{array}{l}.40 \\
.40 \\
.40 \\
.40 \\
.40\end{array}$ & $\begin{array}{l}.20 \\
.20 \\
.20 \\
.20 \\
.20\end{array}$ & $\begin{array}{l}.20 \\
.20 \\
.20 \\
.20 \\
.20\end{array}$ & $\begin{array}{r}.50 \\
.60 \\
.90 \\
1.20 \\
1.00\end{array}$ & $\begin{array}{l}2.6 \\
3.5 \\
3.1 \\
2.4 \\
2.0\end{array}$ & $\begin{array}{l}2.3 \\
1.9 \\
1.8 \\
1.7 \\
1.5\end{array}$ & $\begin{array}{l}.80 \\
.80 \\
.70 \\
.70 \\
.70\end{array}$ & $\begin{array}{r}.70 \\
.70 \\
.50 \\
23.00 \\
1.70\end{array}$ & $\begin{array}{l}4.60 \\
5.90 \\
5.40 \\
4.90 \\
4.40\end{array}$ & $\begin{array}{l}3.2 \\
3.0 \\
2.8 \\
2.7 \\
2.5\end{array}$ \\
\hline $\begin{array}{l}16 \\
17 \\
18 \\
19 \\
20\end{array}$ & $\begin{array}{l}1.20 \\
1.10 \\
1.20 \\
1.20 \\
1.20\end{array}$ & $\begin{array}{r}1.20 \\
12.00 \\
3.50 \\
1.20 \\
.90\end{array}$ & $\begin{array}{l}.40 \\
.40 \\
.40 \\
.40 \\
.40\end{array}$ & $\begin{array}{l}.20 \\
.20 \\
.30 \\
.30 \\
.30\end{array}$ & $\begin{array}{l}.20 \\
.20 \\
.20 \\
.20 \\
.20\end{array}$ & $\begin{array}{r}1.00 \\
1.00 \\
11.00 \\
114.00 \\
65.00\end{array}$ & $\begin{array}{l}1.9 \\
1.8 \\
1.5 \\
1.5 \\
1.6\end{array}$ & $\begin{array}{l}1.4 \\
1.4 \\
1.5 \\
2.1 \\
1.5\end{array}$ & $\begin{array}{l}.70 \\
.60 \\
.70 \\
.70 \\
.90\end{array}$ & $\begin{array}{r}1.20 \\
1.20 \\
1.00 \\
.90 \\
.90\end{array}$ & $\begin{array}{r}3.90 \\
16.00 \\
61.00 \\
9.10 \\
33.00\end{array}$ & $\begin{array}{l}2.5 \\
2.7 \\
2.7 \\
2.3 \\
2.7\end{array}$ \\
\hline $\begin{array}{l}21 \\
22 \\
23 \\
24 \\
25\end{array}$ & $\begin{array}{l}1.30 \\
1.20 \\
1.30 \\
1.40 \\
1.70\end{array}$ & $\begin{array}{l}.70 \\
.60 \\
.90 \\
.70 \\
.60\end{array}$ & $\begin{array}{r}.50 \\
.30 \\
.30 \\
.30 \\
.30\end{array}$ & $\begin{array}{l}.40 \\
.40 \\
.30 \\
.30 \\
.30\end{array}$ & $\begin{array}{l}.20 \\
.20 \\
.50 \\
.40 \\
.30\end{array}$ & $\begin{array}{l}40.00 \\
52.00 \\
83.00 \\
49.00 \\
11.00\end{array}$ & $\begin{array}{l}1.5 \\
1.3 \\
1.2 \\
1.2 \\
1.4\end{array}$ & $\begin{array}{l}1.3 \\
1.3 \\
1.3 \\
1.2 \\
1.1\end{array}$ & $\begin{array}{l}.70 \\
.60 \\
.60 \\
.60 \\
.50\end{array}$ & $\begin{array}{l}.90 \\
1.70 \\
1.00 \\
1.10 \\
1.40\end{array}$ & $\begin{array}{r}11.00 \\
7.60 \\
8.40 \\
7.10 \\
6.20\end{array}$ & $\begin{array}{l}2.3 \\
2.2 \\
2.3 \\
2.3 \\
2.3\end{array}$ \\
\hline $\begin{array}{l}26 \\
27 \\
28 \\
29 \\
30 \\
31\end{array}$ & $\begin{array}{l}1.60 \\
1.50 \\
1.40 \\
1.30 \\
1.30 \\
1.30\end{array}$ & $\begin{array}{l}.60 \\
.60 \\
.50 \\
.60 \\
.60 \\
-.0\end{array}$ & $\begin{array}{r}.30 \\
.30 \\
.30 \\
.30 \\
.30 \\
.30\end{array}$ & $\begin{array}{l}.30 \\
.30 \\
.20 \\
.20 \\
.20 \\
.20\end{array}$ & $\begin{array}{r}.30 \\
.30 \\
.30 \\
-30 \\
-.- \\
-.-\end{array}$ & $\begin{array}{r}9.10 \\
6.00 \\
6.00 \\
18.00 \\
31.00 \\
15.00\end{array}$ & $\begin{array}{l}2.0 \\
1.6 \\
1.5 \\
1.6 \\
1.5 \\
-.0\end{array}$ & $\begin{array}{l}1.2 \\
1.2 \\
1.1 \\
1.0 \\
1.0 \\
1.0\end{array}$ & $\begin{array}{l}.50 \\
.50 \\
.60 \\
.70 \\
.70 \\
-.0\end{array}$ & $\begin{array}{r}1.10 \\
.90 \\
.90 \\
.90 \\
2.60 \\
1.10\end{array}$ & $\begin{array}{l}5.70 \\
7.80 \\
6.20 \\
8.10 \\
5.40 \\
4.90\end{array}$ & $\begin{array}{l}2.0 \\
1.8 \\
1.7 \\
2.0 \\
1.7 \\
-\infty\end{array}$ \\
\hline $\begin{array}{l}\operatorname{mAX} \\
\operatorname{MIN}\end{array}$ & $\begin{array}{l}2.0 \\
\bullet 80\end{array}$ & $\begin{array}{r}12 \\
.50\end{array}$ & $\begin{array}{r}.70 \\
.30\end{array}$ & $\begin{array}{r}.40 \\
.20\end{array}$ & $\begin{array}{r}.50 \\
.20\end{array}$ & $\begin{array}{l}114 \\
.30\end{array}$ & $\begin{array}{r}11 \\
1.2\end{array}$ & $\begin{array}{l}4.7 \\
1.0\end{array}$ & $\begin{array}{l}1.2 \\
.50\end{array}$ & $\begin{array}{r}23 \\
.40\end{array}$ & $\begin{array}{r}79 \\
.90\end{array}$ & $\begin{array}{l}5.6 \\
1.7\end{array}$ \\
\hline
\end{tabular}

WTR YR 1979 MAX 114 MIN .20 
Table 19. Total orthophosphorus for Steiner Branch, 1978 and 1979 water years, in pounds.

TOTAL ORTHOPHOSPHORUS IN POUNDS, WATER YEAR OCTOBER 1977 TO SEPTEMHER 1978

\begin{tabular}{|c|c|c|c|c|c|c|c|c|c|c|c|c|}
\hline DAY & UCT & vov & DEC & JAN & FEA & MAR & $A P R$ & MAY & JUN & JUL & $A U_{6}$ & SEP \\
\hline $\begin{array}{l}1 \\
2 \\
3 \\
4 \\
5\end{array}$ & 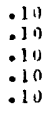 & $\begin{array}{l}.10 \\
.20 \\
.20 \\
.10 \\
.10\end{array}$ & $\begin{array}{l}.10 \\
.10 \\
.10 \\
.10 \\
.10\end{array}$ & $\begin{array}{l}.10 \\
.10 \\
.10 \\
.10 \\
.10\end{array}$ & $\begin{array}{l}.10 \\
.11 \\
.10 \\
.10 \\
.10\end{array}$ & $\begin{array}{l}.10 \\
.10 \\
.10 \\
.10 \\
.10\end{array}$ & $\begin{array}{l}.50 \\
.50 \\
.50 \\
.50 \\
.40\end{array}$ & $\begin{array}{l}.30 \\
.20 \\
.20 \\
.20 \\
.20\end{array}$ & $\begin{array}{l}.40 \\
.40 \\
.40 \\
.30 \\
.30\end{array}$ & $\begin{array}{c}23 \\
4.5 \\
1.4 \\
.80 \\
.50\end{array}$ & $\begin{array}{l}1.0 \\
1.0 \\
.00 \\
.50 \\
.40\end{array}$ & $\begin{array}{l}.10 \\
110 \\
110 \\
110 \\
.10\end{array}$ \\
\hline $\begin{array}{r}6 \\
7 \\
8 \\
9 \\
10\end{array}$ & $\begin{array}{l}.11 \\
.10 \\
.20 \\
.211 \\
.10\end{array}$ & $\begin{array}{l}.10 \\
.10 \\
.10 \\
.10 \\
.10\end{array}$ & $\begin{array}{l}.10 \\
.10 \\
.10 \\
.10 \\
.10\end{array}$ & $\begin{array}{l}.10 \\
.10 \\
.10 \\
.10 \\
.10\end{array}$ & $\begin{array}{l}.110 \\
110 \\
110 \\
110 \\
.10\end{array}$ & $\begin{array}{l}.10 \\
.10 \\
.10 \\
.10 \\
.10\end{array}$ & $\begin{array}{l}11 \\
4.0 \\
1.1 \\
.10 \\
2.0\end{array}$ & $\begin{array}{l}.20 \\
.20 \\
.30 \\
.20 \\
.20\end{array}$ & $\begin{array}{l}.30 \\
.30 \\
.30 \\
.30 \\
.30\end{array}$ & $\begin{array}{c}42 \\
6.2 \\
5.3 \\
3.0 \\
1.2\end{array}$ & $\begin{array}{l}.30 \\
.30 \\
.30 \\
.30 \\
.20\end{array}$ & $\begin{array}{l}.10 \\
.10 \\
.10 \\
.10 \\
.10\end{array}$ \\
\hline $\begin{array}{l}11 \\
12 \\
13 \\
14 \\
15\end{array}$ & $\begin{array}{l}.11 \\
.10 \\
.110 \\
.110 \\
.10\end{array}$ & $\begin{array}{l}.10 \\
.10 \\
.10 \\
.10 \\
.10\end{array}$ & $\begin{array}{l}.10 \\
.10 \\
.10 \\
.10 \\
.10\end{array}$ & $\begin{array}{l}.10 \\
.10 \\
.10 \\
.10 \\
.10\end{array}$ & $\begin{array}{l}.10 \\
10 \\
.10 \\
110 \\
.10\end{array}$ & $\begin{array}{l}.10 \\
.10 \\
.10 \\
.10 \\
.10\end{array}$ & $\begin{array}{l}1.1 \\
.70 \\
.50 \\
.40 \\
.30\end{array}$ & $\begin{array}{l}.20 \\
2.1 \\
73 \\
1 R \\
4.2\end{array}$ & $\begin{array}{l}.20 \\
.20 \\
.20 \\
.20 \\
.20\end{array}$ & $\begin{array}{l}.70 \\
1.6 \\
1.1 \\
.50 \\
.40\end{array}$ & $\begin{array}{l}.20 \\
.20 \\
.20 \\
.20 \\
.20\end{array}$ & $\begin{array}{l}.10 \\
.10 \\
1.4 \\
1.6 \\
.20\end{array}$ \\
\hline $\begin{array}{l}16 \\
17 \\
18 \\
19 \\
70\end{array}$ & 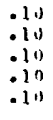 & $\begin{array}{l}.10 \\
.10 \\
.10 \\
.10 \\
.10\end{array}$ & $\begin{array}{l}.10 \\
.10 \\
.10 \\
.10 \\
.110\end{array}$ & $\begin{array}{l}.10 \\
.10 \\
.10 \\
.10 \\
.10\end{array}$ & $\begin{array}{l}.10 \\
.10 \\
.10 \\
.10 \\
.10\end{array}$ & $\begin{array}{r}.10 \\
.10 \\
.10 \\
.40 \\
0.0\end{array}$ & $\begin{array}{l}.30 \\
.30 \\
1.8 \\
.80 \\
.60\end{array}$ & $\begin{array}{l}3.1 \\
2.2 \\
1.7 \\
1.3 \\
1.1\end{array}$ & $\begin{array}{c}8.0 \\
205 \\
10 \\
2.3 \\
.90\end{array}$ & $\begin{array}{r}.40 \\
.40 \\
.30 \\
.30\end{array}$ & $\begin{array}{r}.50 \\
.20 \\
.40 \\
1.2 \\
.20\end{array}$ & $\begin{array}{r}.10 \\
37.60 \\
9.20 \\
9.0\end{array}$ \\
\hline $\begin{array}{l}21 \\
? 2 \\
23 \\
24 \\
? 5\end{array}$ & $\begin{array}{l}.10 \\
.10 \\
.10 \\
.10 \\
.10\end{array}$ & $\begin{array}{l}.10 \\
.10 \\
.10 \\
.10 \\
.10\end{array}$ & $\begin{array}{l}.10 \\
.10 \\
.10 \\
.10 \\
.10\end{array}$ & $\begin{array}{l}.10 \\
.10 \\
.10 \\
.10 \\
.10\end{array}$ & $\begin{array}{l}.10 \\
110 \\
.11 \\
.10 \\
.10\end{array}$ & $\begin{array}{l}18 \\
15 \\
5.6 \\
1.1 \\
.50\end{array}$ & $\begin{array}{l}.60 \\
.40 \\
.50 \\
.50 \\
.40\end{array}$ & $\begin{array}{l}1.0 \\
.80 \\
.90 \\
.80 \\
.70\end{array}$ & $\begin{array}{r}.50 \\
.30 \\
.20 \\
15^{.20}\end{array}$ & $\begin{array}{r}12 \\
9.0 \\
7.0 \\
5.0 \\
4.2\end{array}$ & $\begin{array}{l}.20 \\
.20 \\
.20 \\
.10 \\
.10\end{array}$ & $\begin{array}{r}1.7 \\
.40 \\
.20 \\
.10 \\
.10\end{array}$ \\
\hline $\begin{array}{l}26 \\
27 \\
28 \\
24 \\
70 \\
31\end{array}$ & $\begin{array}{l}.10 \\
110 \\
110 \\
1110 \\
.110 \\
.10\end{array}$ & $\begin{array}{l}.10 \\
.10 \\
.10 \\
.10 \\
.10 \\
-\infty-0\end{array}$ & $\begin{array}{l}.10 \\
.10 \\
.10 \\
.10 \\
.10 \\
.10\end{array}$ & 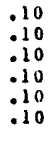 & $\begin{array}{l}110 \\
110 \\
110 \\
-10 \\
-0-\end{array}$ & $\begin{array}{l}.40 \\
.50 \\
.60 \\
.50 \\
.50 \\
.60\end{array}$ & $\begin{array}{r}.30 \\
.30 \\
.30 \\
.30 \\
.30 \\
-.3\end{array}$ & $\begin{array}{r}.50 \\
.80 \\
1.0 \\
.60 \\
.60 \\
.50\end{array}$ & $\begin{array}{l}1.4 \\
.40 \\
.20 \\
.20 \\
1.4 \\
.\end{array}$ & $\begin{array}{l}6.5 \\
4.7 \\
2.3 \\
1.8 \\
1.3 \\
6.0\end{array}$ & $\begin{array}{r}.10 \\
.30 \\
5.3 \\
.60 \\
.10 \\
.10\end{array}$ & $\begin{array}{l}.10 \\
.10 \\
110 \\
110 \\
.10 \\
-10\end{array}$ \\
\hline MF.AN & .11 & .11 & .10 & .10 & .10 & 1.7 & 1.1 & 3.8 & 8.3 & 10 & .53 & 1.8 \\
\hline WTR Y & & & & $\operatorname{MAX}$ & 205 & & & 10 & & & & \\
\hline
\end{tabular}

TOTAL ORTHOPHOSPHORUS IN POUNOS, WATER YEAR OCTOBER 1978 TO SEPTEMBER 1979

\begin{tabular}{|c|c|c|c|c|c|c|c|c|c|c|c|c|}
\hline DAY & UCT & vor & DEC & JAN & FEB & MAR & $A P R$ & MAY & JUN & JUL & AUG & SEP \\
\hline $\begin{array}{l}1 \\
2 \\
3 \\
4 \\
5\end{array}$ & $\begin{array}{l}.10 \\
.20 \\
.30 \\
.20 \\
.40\end{array}$ & $\begin{array}{l}.20 \\
.20 \\
.20 \\
.20 \\
.20\end{array}$ & $\begin{array}{r}.20 \\
.20 \\
.30 \\
.30 \\
.20\end{array}$ & $\begin{array}{l}.10 \\
.10 \\
.10 \\
.10 \\
.10\end{array}$ & $\begin{array}{l}.10 \\
.10 \\
.10 \\
.10 \\
110\end{array}$ & $\begin{array}{r}.10 \\
.20 \\
.20 \\
.30 \\
.30\end{array}$ & $\begin{array}{l}3.6 \\
4.3 \\
2.5 \\
2.5 \\
2.0\end{array}$ & $\begin{array}{l}.40 \\
.80 \\
1.4 \\
1.0 \\
1.0\end{array}$ & $\begin{array}{l}.30 \\
.20 \\
.20 \\
.20 \\
.30\end{array}$ & $\begin{array}{l}.20 \\
.20 \\
.20 \\
.20 \\
.10\end{array}$ & $\begin{array}{r}.30 \\
.30 \\
.50 \\
16.60\end{array}$ & $\begin{array}{r}.80 \\
.70 \\
.70 \\
1.00 \\
.50\end{array}$ \\
\hline $\begin{array}{r}6 \\
7 \\
8 \\
9 \\
10\end{array}$ & $\begin{array}{l}.30 \\
.20 \\
.20 \\
.70 \\
.60\end{array}$ & $\begin{array}{l}.20 \\
.20 \\
.20 \\
.20 \\
.20\end{array}$ & $\begin{array}{l}.20 \\
.20 \\
.20 \\
.20 \\
.10\end{array}$ & $\begin{array}{l}110 \\
.10 \\
.10 \\
.10 \\
.10\end{array}$ & $\begin{array}{l}.10 \\
110 \\
.10 \\
.10 \\
10\end{array}$ & $\begin{array}{r}.30 \\
.30 \\
.20 \\
.20 \\
.20\end{array}$ & $\begin{array}{l}2.5 \\
1.4 \\
1.5 \\
1.3 \\
1.1\end{array}$ & $\begin{array}{l}1.0 \\
1.0 \\
.90 \\
.70 \\
.60\end{array}$ & $\begin{array}{l}.20 \\
.20 \\
.20 \\
.20 \\
.30\end{array}$ & $\begin{array}{l}.10 \\
.10 \\
.10 \\
.10 \\
.10\end{array}$ & $\begin{array}{l}3.6 \\
1.0 \\
1.0 \\
14 \\
30\end{array}$ & $\begin{array}{l}.50 \\
.60 \\
.60 \\
.50 \\
.60\end{array}$ \\
\hline $\begin{array}{l}11 \\
12 \\
13 \\
14 \\
15\end{array}$ & $\begin{array}{l}.40 \\
.30 \\
.20 \\
.20 \\
.20\end{array}$ & $\begin{array}{r}.20 \\
.10 \\
2.0 \\
.50 \\
.30\end{array}$ & $\begin{array}{l}.20 \\
.30 \\
.20 \\
.20 \\
.20\end{array}$ & $\begin{array}{l}110 \\
110 \\
.10 \\
.10 \\
.10\end{array}$ & $\begin{array}{l}.10 \\
.10 \\
.10 \\
.10 \\
.10\end{array}$ & $\begin{array}{l}.20 \\
.30 \\
.40 \\
.50 \\
.50\end{array}$ & $\begin{array}{l}1.2 \\
1.5 \\
1.4 \\
1.1 \\
.90\end{array}$ & $\begin{array}{l}.70 \\
.60 \\
.50 \\
.50 \\
.40\end{array}$ & $\begin{array}{l}.20 \\
.20 \\
.20 \\
.20 \\
.20\end{array}$ & $\begin{array}{l}.10 \\
: 10 \\
.10 \\
5.1 \\
1.0\end{array}$ & $\begin{array}{l}5.1 \\
4.0 \\
3.0 \\
2.1 \\
1.5\end{array}$ & $\begin{array}{l}.40 \\
.40 \\
.30 \\
.30 \\
.30\end{array}$ \\
\hline $\begin{array}{l}16 \\
17 \\
18 \\
19 \\
20\end{array}$ & $\begin{array}{l}.20 \\
.20 \\
.20 \\
.20 \\
.30\end{array}$ & $\begin{array}{l}.20 \\
4.4 \\
2.0 \\
.60 \\
.40\end{array}$ & $\begin{array}{l}.20 \\
.20 \\
.20 \\
.20 \\
.20\end{array}$ & $\begin{array}{l}10 \\
.10 \\
.10 \\
.10 \\
.10\end{array}$ & $\begin{array}{l}.10 \\
110 \\
.10 \\
.10 \\
.10\end{array}$ & $\begin{array}{l}.40 \\
.50 \\
1.60 \\
21 \\
19\end{array}$ & $\begin{array}{l}.90 \\
.80 \\
.70 \\
.70 \\
.80\end{array}$ & $\begin{array}{l}.40 \\
.40 \\
.40 \\
.60 \\
.40\end{array}$ & $\begin{array}{l}.20 \\
.20 \\
.20 \\
.20 \\
.20\end{array}$ & $\begin{array}{l}.40 \\
.40 \\
.30 \\
.30 \\
.30\end{array}$ & $\begin{array}{c}1.0 \\
5.9 \\
28 \\
2.2 \\
18\end{array}$ & $\begin{array}{r}.30 \\
.30 \\
.30 \\
.20 \\
.30\end{array}$ \\
\hline $\begin{array}{l}21 \\
22 \\
23 \\
24 \\
25\end{array}$ & $\begin{array}{r}.30 \\
.30 \\
.30 \\
.30 \\
.50\end{array}$ & $\begin{array}{l}.30 \\
.30 \\
.40 \\
.30 \\
.20\end{array}$ & $\begin{array}{l}20 \\
.10 \\
110 \\
.10 \\
.10\end{array}$ & $\begin{array}{l}110 \\
110 \\
10 \\
.10 \\
110\end{array}$ & $\begin{array}{l}.10 \\
.10 \\
.20 \\
.10 \\
.10\end{array}$ & $\begin{array}{l}12 \\
20 \\
34 \\
21 \\
5.8\end{array}$ & $\begin{array}{l}.70 \\
.60 \\
.60 \\
.60 \\
.70\end{array}$ & $\begin{array}{l}.40 \\
.40 \\
.40 \\
.30 \\
.30\end{array}$ & $\begin{array}{l}.20 \\
.20 \\
.20 \\
.20 \\
.20\end{array}$ & $\begin{array}{l}.30 \\
.60 \\
.30 \\
.40 \\
.50\end{array}$ & $\begin{array}{l}3.2 \\
3.8 \\
2.0 \\
1.5 \\
1.2\end{array}$ & $\begin{array}{l}.20 \\
.20 \\
.20 \\
.20 \\
.20\end{array}$ \\
\hline $\begin{array}{l}26 \\
27 \\
28 \\
29 \\
30 \\
31\end{array}$ & $\begin{array}{r}.50 \\
.40 \\
.30 \\
.30 \\
.30 \\
.30\end{array}$ & $\begin{array}{l}.20 \\
.20 \\
.20 \\
.20 \\
.20 \\
-.-\end{array}$ & $\begin{array}{l}10 \\
.10 \\
.10 \\
110 \\
110 \\
.10\end{array}$ & $\begin{array}{l}.10 \\
.10 \\
.10 \\
.10 \\
.10 \\
.10\end{array}$ & $\begin{array}{l}10 \\
110 \\
110 \\
-10 \\
-\square\end{array}$ & $\begin{array}{c}3.6 \\
2.5 \\
2.5 \\
6.7 \\
11 \\
5.8\end{array}$ & $\begin{array}{l}.90 \\
.70 \\
.40 \\
.40 \\
.40 \\
---\end{array}$ & $\begin{array}{r}.30 \\
.30 \\
.30 \\
.30 \\
.30 \\
.30\end{array}$ & $\begin{array}{l}.20 \\
.20 \\
.20 \\
.20 \\
.20 \\
-.-\end{array}$ & $\begin{array}{r}.40 \\
.30 \\
.30 \\
.30 \\
.90 \\
.40\end{array}$ & $\begin{array}{l}1.0 \\
1.7 \\
1.2 \\
1.8 \\
.90 \\
.80\end{array}$ & $\begin{array}{l}.20 \\
.20 \\
.10 \\
.20 \\
.10 \\
-.0\end{array}$ \\
\hline MEAN & .30 & .51 & .17 & .10 & .10 & 5.5 & 1.3 & .56 & .21 & .46 & 5.1 & .38 \\
\hline
\end{tabular}


Table 20. Water temperatures of Steiner Branch, 1978 and 1979 water years.

TEMPERAIURE, WATER (DEG. C), WATER YEAR OCTUBER 1977 TU SEPTEMGER 1978

\begin{tabular}{|c|c|c|c|c|c|c|c|c|c|c|c|c|}
\hline \multirow[t]{2}{*}{ DAY } & $\operatorname{MAX}$ & MIN & MEAN & MAX & MIN & MEAN & $\max$ & MIN & MEAN & $\max$ & MIN & MEAN \\
\hline & \multicolumn{3}{|c|}{ OCTUAER } & \multicolumn{3}{|c|}{ NOVEMBER } & \multicolumn{3}{|c|}{ UECEMBER } & \multicolumn{3}{|c|}{ JANUAKY } \\
\hline $\begin{array}{l}1 \\
2 \\
3 \\
4 \\
5\end{array}$ & $=$ & $=0$ & 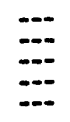 & $\begin{array}{l}11.0 \\
12.0 \\
12.5 \\
10.0 \\
10.0\end{array}$ & $\begin{array}{r}10.5 \\
10.5 \\
10.0 \\
8.0 \\
6.5\end{array}$ & $\begin{array}{r}11.0 \\
11.0 \\
11.5 \\
9.0 \\
8.5\end{array}$ & $\begin{array}{l}3.0 \\
3.5 \\
1.0 \\
1.0 \\
2.0\end{array}$ & $\begin{array}{r}1.0 \\
1.0 \\
.5 \\
.5 \\
1.0\end{array}$ & $\begin{array}{r}2.0 \\
2.5 \\
.5 \\
.5 \\
1.5\end{array}$ & $\begin{array}{r}.5 \\
.5 \\
.5 \\
.5 \\
2.0\end{array}$ & $\begin{array}{l}.5 \\
.5 \\
.5 \\
.5 \\
.5\end{array}$ & $\begin{array}{r}.5 \\
.5 \\
.5 \\
.5 \\
1.0\end{array}$ \\
\hline $\begin{array}{r}6 \\
7 \\
8 \\
9 \\
10\end{array}$ & 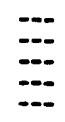 & 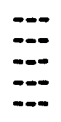 & $\begin{array}{l}\ldots- \\
\cdots \\
\cdots- \\
\cdots\end{array}$ & $\begin{array}{r}10.5 \\
11.5 \\
12.0 \\
12.5 \\
8.0\end{array}$ & $\begin{array}{r}10.0 \\
10.5 \\
11.0 \\
8.0 \\
5.5\end{array}$ & $\begin{array}{r}10.0 \\
11.0 \\
11.5 \\
11.0 \\
6.5\end{array}$ & $\begin{array}{r}1.5 \\
.5 \\
.5 \\
.5 \\
.5\end{array}$ & $\begin{array}{l}.5 \\
.5 \\
.5 \\
.5 \\
.5\end{array}$ & $\begin{array}{l}.5 \\
.5 \\
.5 \\
.5 \\
.5\end{array}$ & $\begin{array}{r}3.0 \\
4.0 \\
3.5 \\
.5 \\
.5\end{array}$ & $\begin{array}{r}1.5 \\
3.0 \\
.5 \\
.5 \\
.5\end{array}$ & $\begin{array}{l}2.5 \\
3.5 \\
1.0 \\
.5 \\
.5\end{array}$ \\
\hline $\begin{array}{l}11 \\
12 \\
13 \\
14 \\
15\end{array}$ & $\ddot{-\infty}$ & $=$ & 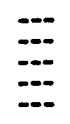 & $\begin{array}{l}5.5 \\
4.5 \\
5.0 \\
7.0 \\
8.5\end{array}$ & $\begin{array}{l}3.0 \\
2.0 \\
1.5 \\
3.0 \\
5.5\end{array}$ & $\begin{array}{l}4.5 \\
3.0 \\
3.5 \\
5.0 \\
7.0\end{array}$ & $\begin{array}{r}.5 \\
.5 \\
2.5 \\
3.5 \\
4.5\end{array}$ & $\begin{array}{r}.5 \\
.5 \\
1.0 \\
2.5 \\
3.0\end{array}$ & $\begin{array}{r}.5 \\
.5 \\
2.0 \\
3.0 \\
3.5\end{array}$ & $\begin{array}{r}.5 \\
.5 \\
.5 \\
.5 \\
1.5\end{array}$ & $\begin{array}{l}.5 \\
.5 \\
.5 \\
.5 \\
.5\end{array}$ & $\begin{array}{r}.5 \\
.5 \\
.5 \\
.5 \\
1.0\end{array}$ \\
\hline $\begin{array}{l}16 \\
17 \\
18 \\
19 \\
20\end{array}$ & 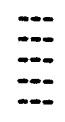 & $=$ & $\ddot{-\infty}$ & $\begin{array}{l}7.5 \\
5.5 \\
6.0 \\
6.0 \\
9.0\end{array}$ & $\begin{array}{l}5.0 \\
3.5 \\
4.5 \\
4.5 \\
5.0\end{array}$ & $\begin{array}{l}6.0 \\
5.0 \\
5.0 \\
5.0 \\
7.0\end{array}$ & $\begin{array}{l}5.0 \\
5.5 \\
5.0 \\
5.0 \\
3.5\end{array}$ & $\begin{array}{l}3.0 \\
5.0 \\
5.0 \\
3.5 \\
1.0\end{array}$ & $\begin{array}{l}4.5 \\
5.0 \\
5.0 \\
4.5 \\
2.0\end{array}$ & $\begin{array}{l}1.5 \\
1.5 \\
2.0 \\
2.5 \\
2.0\end{array}$ & $\begin{array}{l}1.0 \\
1.0 \\
1.0 \\
2.0 \\
1.5\end{array}$ & $\begin{array}{l}1.0 \\
1.0 \\
1.5 \\
2.0 \\
2.0\end{array}$ \\
\hline $\begin{array}{l}21 \\
22 \\
23 \\
24 \\
25\end{array}$ & 12.0 & $\ddot{-\ldots}$ & $=0$ & $\begin{array}{l}4.5 \\
3.5 \\
5.0 \\
4.0 \\
1.0\end{array}$ & $\begin{array}{r}1.5 \\
1.0 \\
1.5 \\
1.5 \\
.5\end{array}$ & $\begin{array}{r}2.5 \\
2.5 \\
3.5 \\
3.0 \\
.5\end{array}$ & $\begin{array}{r}2.5 \\
2.5 \\
2.5 \\
3.5 \\
.5\end{array}$ & $\begin{array}{r}1.0 \\
.5 \\
.5 \\
.5 \\
.5\end{array}$ & $\begin{array}{l}1.5 \\
1.5 \\
1.5 \\
1.5 \\
.5\end{array}$ & $\begin{array}{l}2.0 \\
1.5 \\
2.0 \\
2.0 \\
2.0\end{array}$ & $\begin{array}{r}1.0 \\
.5 \\
1.0 \\
1.0 \\
.5\end{array}$ & $\begin{array}{l}1.5 \\
1.0 \\
1.5 \\
2.0 \\
1.5\end{array}$ \\
\hline $\begin{array}{l}26 \\
27 \\
28 \\
29 \\
30 \\
31\end{array}$ & $\begin{array}{l}11.0 \\
13.0 \\
11.5 \\
11.0 \\
11.0 \\
11.0\end{array}$ & $\begin{array}{r}10.0 \\
10.0 \\
8.0 \\
8.0 \\
8.0 \\
9.5\end{array}$ & $\begin{array}{r}10.5 \\
11.5 \\
9.5 \\
9.5 \\
9.5 \\
10.0\end{array}$ & $\begin{array}{r}1.0 \\
.5 \\
.5 \\
1.0 \\
1.0 \\
-0\end{array}$ & $\begin{array}{r}.5 \\
.5 \\
.5 \\
.5 \\
.5 \\
.-0\end{array}$ & $\begin{array}{r}.5 \\
.5 \\
.5 \\
.5 \\
.5 \\
. .0\end{array}$ & $\begin{array}{r}.5 \\
.5 \\
.5 \\
.5 \\
2.0 \\
2.0\end{array}$ & $\begin{array}{l}.5 \\
.5 \\
.5 \\
.5 \\
.5 \\
.5\end{array}$ & $\begin{array}{r}.5 \\
.5 \\
.5 \\
.5 \\
1.0 \\
1.5\end{array}$ & $\begin{array}{r}1.5 \\
1.0 \\
1.0 \\
.5 \\
.5 \\
1.0\end{array}$ & $\begin{array}{l}.5 \\
.5 \\
.5 \\
.5 \\
.5 \\
.5\end{array}$ & $\begin{array}{r}1.0 \\
.5 \\
.5 \\
.5 \\
.5 \\
.5\end{array}$ \\
\hline MONTH & 13.0 & 8.0 & 10.5 & 12.5 & .5 & 5.5 & 5.5 & .5 & 1.5 & 4.0 & .5 & 1.0 \\
\hline
\end{tabular}

TEMPERATURE, WATER (DEG. C), WATER YEAR OCTOBER 1977 TO SEPTEMBER 1978

\begin{tabular}{|c|c|c|c|c|c|c|c|c|c|c|c|c|}
\hline \multirow[t]{2}{*}{ DAY } & $\max$ & MIN & MEAN & $\max$ & MIN & MEAN & $\max$ & MIN & MEAN & $\max$ & MIN & MEAN \\
\hline & \multicolumn{3}{|c|}{ FEERUARY } & \multicolumn{3}{|c|}{ MARCH } & \multicolumn{3}{|c|}{ APRIL } & \multicolumn{3}{|c|}{ maY } \\
\hline $\begin{array}{r}1 \\
2 \\
3 \\
1 \\
5\end{array}$ & $\begin{array}{l}1.0 \\
1.0 \\
1.5 \\
1.5 \\
1.5\end{array}$ & $\begin{array}{r}.5 \\
.5 \\
.5 \\
.5 \\
1.0\end{array}$ & $\begin{array}{r}.5 \\
1.0 \\
1.0 \\
1.0 \\
1.0\end{array}$ & $\begin{array}{l}2.5 \\
2.0 \\
2.5 \\
1.0 \\
1.0\end{array}$ & $\begin{array}{r}.5 \\
.5 \\
1.0 \\
.5 \\
.5\end{array}$ & $\begin{array}{l}1.5 \\
1.0 \\
1.5 \\
1.0 \\
1.0\end{array}$ & $\begin{array}{r}13.0 \\
7.0 \\
12.0 \\
10.5 \\
8.5\end{array}$ & $\begin{array}{l}6.5 \\
3.5 \\
4.0 \\
7.0 \\
4.0\end{array}$ & $\begin{array}{l}9.5 \\
4.5 \\
7.5 \\
8.5 \\
6.5\end{array}$ & $\begin{array}{r}15.0 \\
16.0 \\
15.0 \\
10.0 \\
9.0\end{array}$ & $\begin{array}{l}4.5 \\
5.0 \\
5.5 \\
7.5 \\
6.5\end{array}$ & $\begin{array}{r}9.5 \\
10.0 \\
10.5 \\
8.5 \\
7.5\end{array}$ \\
\hline $\begin{array}{r}6 \\
7 \\
8 \\
9 \\
10\end{array}$ & $\begin{array}{l}1.0 \\
1.0 \\
2.0 \\
2.0 \\
1.0\end{array}$ & $\begin{array}{r}.5 \\
.5 \\
.5 \\
1.5 \\
.5\end{array}$ & $\begin{array}{l}.5 \\
1.0 \\
1.5 \\
1.5 \\
1.0\end{array}$ & $\begin{array}{l}3.0 \\
3.5 \\
3.5 \\
3.5 \\
5.0\end{array}$ & $\begin{array}{l}1.0 \\
1.0 \\
1.0 \\
1.0 \\
1.5\end{array}$ & $\begin{array}{l}2.0 \\
2.0 \\
2.0 \\
2.0 \\
3.0\end{array}$ & $\begin{array}{r}9.0 \\
14.5 \\
8.5 \\
12.5 \\
9.0\end{array}$ & $\begin{array}{l}6.0 \\
4.5 \\
5.5 \\
5.0 \\
7.0\end{array}$ & $\begin{array}{l}7.5 \\
9.0 \\
6.5 \\
8.5 \\
8.0\end{array}$ & $\begin{array}{l}14.5 \\
10.5 \\
17.0 \\
12.5 \\
20.0\end{array}$ & $\begin{array}{l}5.0 \\
9.0 \\
9.0 \\
9.0 \\
7.0\end{array}$ & $\begin{array}{r}9.5 \\
9.5 \\
12.0 \\
10.5 \\
13.0\end{array}$ \\
\hline $\begin{array}{l}11 \\
12 \\
13 \\
14 \\
15\end{array}$ & $\begin{array}{l}2.0 \\
2.5 \\
2.0 \\
2.0 \\
2.0\end{array}$ & $\begin{array}{r}.5 \\
1.0 \\
1.0 \\
.5 \\
1.0\end{array}$ & $\begin{array}{l}1.0 \\
2.0 \\
1.5 \\
1.5 \\
1.5\end{array}$ & $\begin{array}{l}5.0 \\
5.0 \\
4.5 \\
5.0 \\
5.5\end{array}$ & $\begin{array}{l}3.0 \\
3.0 \\
2.5 \\
3.0 \\
3.0\end{array}$ & $\begin{array}{l}4.0 \\
4.0 \\
3.5 \\
4.0 \\
4.0\end{array}$ & $\begin{array}{l}11.5 \\
14.0 \\
12.5 \\
11.0 \\
14.0\end{array}$ & $\begin{array}{l}5.5 \\
5.0 \\
4.5 \\
4.5 \\
3.5\end{array}$ & $\begin{array}{l}8.0 \\
9.0 \\
8.0 \\
7.5 \\
8.5\end{array}$ & $\begin{array}{l}18.5 \\
19.5 \\
14.5 \\
11.0 \\
14.0\end{array}$ & $\begin{array}{r}12.0 \\
13.0 \\
9.5 \\
9.0 \\
9.0\end{array}$ & $\begin{array}{r}15.0 \\
16.0 \\
11.0 \\
9.5 \\
11.0\end{array}$ \\
\hline $\begin{array}{l}16 \\
17 \\
18 \\
19 \\
20\end{array}$ & $\begin{array}{l}1.5 \\
1.0 \\
1.0 \\
1.0 \\
1.5\end{array}$ & $\begin{array}{l}.5 \\
.5 \\
.5 \\
.5 \\
.5\end{array}$ & $\begin{array}{r}1.0 \\
.5 \\
.5 \\
.5 \\
160\end{array}$ & $\begin{array}{l}6.0 \\
5.5 \\
5.5 \\
7.0 \\
-\infty\end{array}$ & $\begin{array}{r}1.5 \\
.0 \\
1.0 \\
1.5\end{array}$ & $\begin{array}{l}3.5 \\
2.5 \\
3.0 \\
3.5 \\
-\infty\end{array}$ & $\begin{array}{r}14.0 \\
9.0 \\
10.0 \\
7.5 \\
7.5\end{array}$ & $\begin{array}{l}4.5 \\
4.0 \\
5.5 \\
6.5 \\
5.5\end{array}$ & $\begin{array}{l}9.0 \\
7.0 \\
7.5 \\
7.0 \\
6.5\end{array}$ & $\begin{array}{l}13.0 \\
17.0 \\
21.0 \\
20.5 \\
19.5\end{array}$ & $\begin{array}{r}10.0 \\
9.0 \\
10.0 \\
11.0 \\
13.5\end{array}$ & $\begin{array}{l}11.5 \\
13.0 \\
15.0 \\
15.5 \\
16.5\end{array}$ \\
\hline $\begin{array}{l}21 \\
22 \\
23 \\
24 \\
25\end{array}$ & $\begin{array}{l}1.0 \\
1.0 \\
2.5 \\
3.0 \\
3.0\end{array}$ & $\begin{array}{r}.5 \\
.5 \\
1.0 \\
1.5 \\
2.0\end{array}$ & $\begin{array}{r}.5 \\
.5 \\
1.5 \\
2.5 \\
2.5\end{array}$ & $\begin{array}{l}6.5 \\
7.0 \\
8.5 \\
5.0 \\
2.0\end{array}$ & $\begin{array}{r}.05 \\
1.0 \\
1.0 \\
.05 \\
1.0\end{array}$ & $\begin{array}{l}2.5 \\
3.0 \\
4.5 \\
2.5 \\
1.5\end{array}$ & $\begin{array}{l}14.0 \\
12.0 \\
12.0 \\
11.0 \\
15.5\end{array}$ & $\begin{array}{l}4.0 \\
3.5 \\
7.0 \\
6.5 \\
6.0\end{array}$ & $\begin{array}{r}8.5 \\
8.0 \\
9.0 \\
8.5 \\
10.0\end{array}$ & $\begin{array}{l}21.0 \\
18.0 \\
15.0 \\
20.0 \\
23.5\end{array}$ & $\begin{array}{l}11.00 \\
11.00 \\
13.0 \\
12.5 \\
13.0\end{array}$ & $\begin{array}{l}15.5 \\
14.5 \\
14.0 \\
16.0 \\
18.0\end{array}$ \\
\hline $\begin{array}{l}26 \\
27 \\
28 \\
29 \\
30 \\
31\end{array}$ & $\begin{array}{l}2.5 \\
2.5 \\
3.5 \\
-\infty-\infty \\
-\infty-\infty\end{array}$ & $\begin{array}{l}1.0 \\
.5 \\
2.0 \\
-\infty \\
-\infty\end{array}$ & $\begin{array}{l}1.5 \\
1.5 \\
2.5 \\
-0.0 \\
-\infty\end{array}$ & $\begin{array}{r}6.5 \\
4.5 \\
8.5 \\
10.0 \\
11.0 \\
14.5\end{array}$ & $\begin{array}{l}1.5 \\
1.0 \\
4.5 \\
2.0 \\
5.0 \\
4.5\end{array}$ & $\begin{array}{l}3.5 \\
2.0 \\
6.5 \\
6.0 \\
7.5 \\
9.5\end{array}$ & $\begin{array}{r}15.5 \\
16.0 \\
17.5 \\
14.0 \\
15.5 \\
-0.0\end{array}$ & $\begin{array}{l}5.0 \\
5.5 \\
6.5 \\
9.0 \\
6.0 \\
-.0\end{array}$ & $\begin{array}{l}10.0 \\
10.5 \\
12.0 \\
11.5 \\
10.0 \\
\end{array}$ & $\begin{array}{l}25.5 \\
24.0 \\
23.5 \\
24.0 \\
21.0 \\
23.5\end{array}$ & $\begin{array}{l}15.0 \\
15.5 \\
16.0 \\
16.0 \\
14.5 \\
13.5\end{array}$ & $\begin{array}{l}20.5 \\
19.5 \\
19.5 \\
19.5 \\
18.0 \\
18.5\end{array}$ \\
\hline MONTM & 3.5 & .5 & 1.0 & 14.5 & .0 & 3.5 & 17.5 & 3.5 & 8.5 & 25.5 & 4.5 & 14.0 \\
\hline
\end{tabular}


Table 20. Water temperatures of Steiner Branch, 1978 and 1979 water years.

TEMPERATURE, WATER (OEG, C), WATER YEAR OCTOBER 1977 TO SEPTEMBER 1978

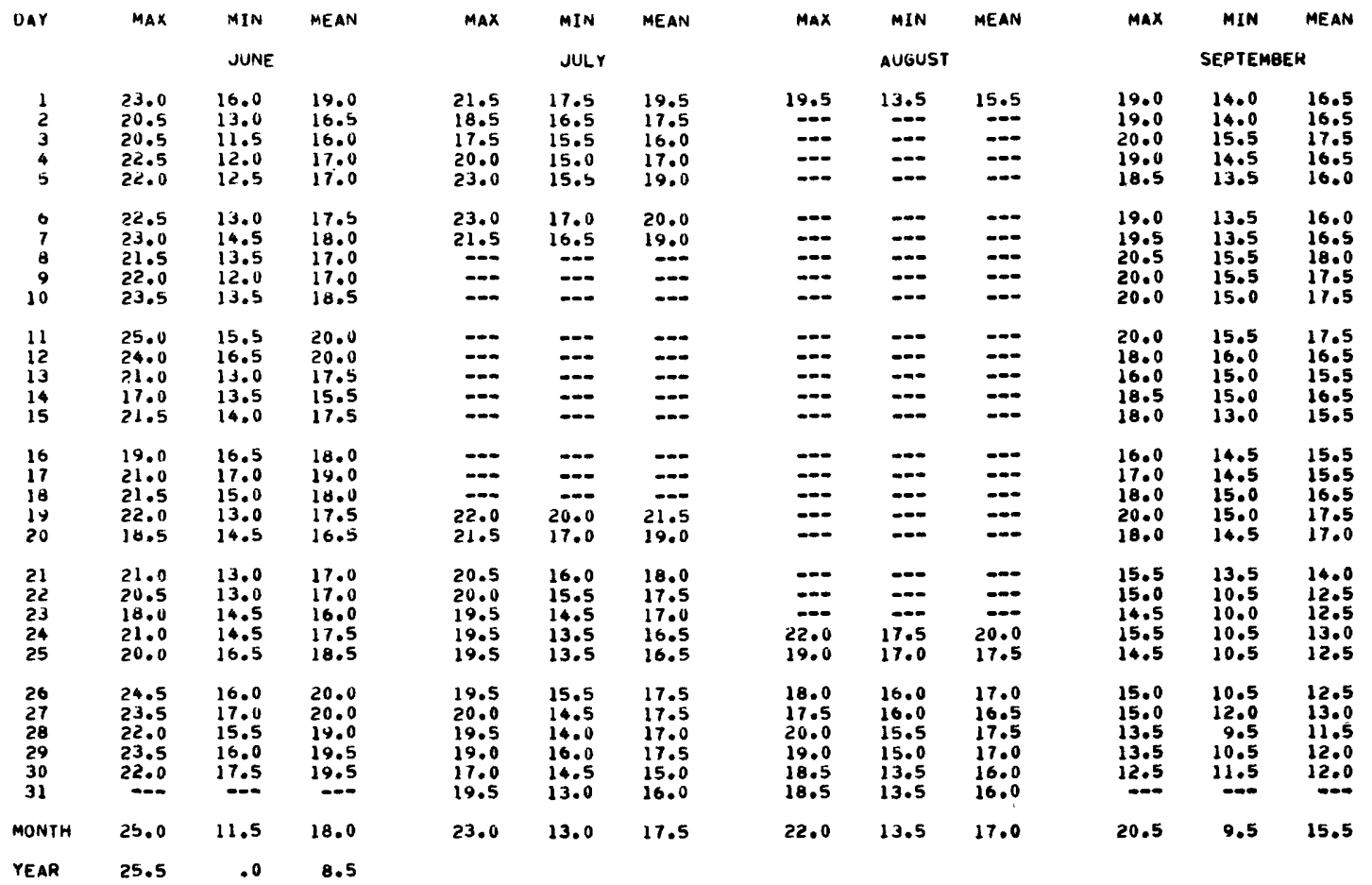

TEMPERATURE, WATER IDEg. CI, WATER YEAR OCTOBER 1978 TO SEPTEMBER 1979

\begin{tabular}{|c|c|c|c|c|c|c|c|c|c|c|c|c|}
\hline \multirow[t]{2}{*}{ DAY } & $\max$ & MIN & MEAN & $\max$ & MIN & MEAN & $\max$ & MIN & MEAN & $\max$ & MIN & MEAN \\
\hline & \multicolumn{3}{|c|}{ OCTUBER } & \multicolumn{3}{|c|}{ NOVEMBER } & \multicolumn{3}{|c|}{ DECEMGER } & \multicolumn{3}{|c|}{ JANUARY } \\
\hline $\begin{array}{l}1 \\
2 \\
3 \\
4 \\
5\end{array}$ & $\begin{array}{l}14.5 \\
13.0 \\
14.5 \\
13.5 \\
12.5\end{array}$ & $\begin{array}{l}10.0 \\
10.5 \\
12.5 \\
11.0 \\
11.5\end{array}$ & $\begin{array}{l}12.0 \\
12.0 \\
13.5 \\
12.0 \\
12.0\end{array}$ & $\begin{array}{r}9.0 \\
10.5 \\
11.5 \\
12.0 \\
11.5\end{array}$ & $\begin{array}{l}6.0 \\
6.5 \\
7.0 \\
9.0 \\
9.0\end{array}$ & $\begin{array}{r}7.5 \\
8.5 \\
9.5 \\
10.5 \\
10.5\end{array}$ & $\begin{array}{l}3.5 \\
3.0 \\
3.0 \\
2.5 \\
4.5\end{array}$ & $\begin{array}{l}2.0 \\
1.5 \\
1.5 \\
1.0 \\
2.5\end{array}$ & $\begin{array}{l}3.0 \\
2.0 \\
2.0 \\
2.0 \\
3.5\end{array}$ & $\begin{array}{l}1.5 \\
1.0 \\
-\infty \\
-\infty\end{array}$ & $\begin{array}{l}1.0 \\
1.0 \\
-\infty\end{array}$ & $\begin{array}{l}1.0 \\
1.0 \\
0.0\end{array}$ \\
\hline $\begin{array}{r}6 \\
7 \\
8 \\
9 \\
10\end{array}$ & $\begin{array}{l}12.0 \\
11.0 \\
11.5 \\
12.0 \\
12.5\end{array}$ & $\begin{array}{r}11.0 \\
9.5 \\
7.5 \\
10.0 \\
11.5\end{array}$ & $\begin{array}{r}11.5 \\
10.0 \\
9.5 \\
11.0 \\
12.0\end{array}$ & $\begin{array}{r}10.0 \\
8.0 \\
9.0 \\
10.0 \\
10.0\end{array}$ & $\begin{array}{l}7.0 \\
5.5 \\
5.5 \\
7.0 \\
7.5\end{array}$ & $\begin{array}{l}9.5 \\
6.5 \\
7.5 \\
8.5 \\
9.0\end{array}$ & $\begin{array}{l}-0.0 \\
3.0 \\
2.5 \\
1.5 \\
1.5\end{array}$ & $\begin{array}{l}-1.5 \\
1.0 \\
1.0 \\
1.0\end{array}$ & $\begin{array}{l}-0.5 \\
2.5 \\
1.5 \\
1.5 \\
1.0\end{array}$ & $\ddot{-\infty}$ & $=$ & $=$ \\
\hline $\begin{array}{l}11 \\
12 \\
13 \\
14 \\
15\end{array}$ & $\begin{array}{l}13.5 \\
12.0 \\
11.5 \\
10.0 \\
11.0\end{array}$ & $\begin{array}{r}11.5 \\
10.5 \\
8.5 \\
8.0 \\
8.5\end{array}$ & $\begin{array}{r}12.5 \\
11.0 \\
10.0 \\
9.0 \\
9.5\end{array}$ & $\begin{array}{r}9.0 \\
7.5 \\
10.0 \\
7.5 \\
6.5\end{array}$ & $\begin{array}{l}7.0 \\
6.5 \\
7.5 \\
4.5 \\
4.0\end{array}$ & $\begin{array}{l}8.5 \\
7.0 \\
8.5 \\
6.0 \\
5.0\end{array}$ & $\begin{array}{l}2.0 \\
4.0 \\
3.0 \\
3.5 \\
4.0\end{array}$ & $\begin{array}{l}1.5 \\
2.0 \\
1.5 \\
1.5 \\
2.5\end{array}$ & $\begin{array}{l}1.5 \\
3.0 \\
2.5 \\
2.5 \\
3.0\end{array}$ & $=0$ & $=$ & $=$ \\
\hline $\begin{array}{l}16 \\
17 \\
18 \\
19 \\
20\end{array}$ & $\begin{array}{l}10.5 \\
10.0 \\
10.5 \\
11.0 \\
12.0\end{array}$ & $\begin{array}{l}8.5 \\
7.0 \\
7.5 \\
7.0 \\
8.0\end{array}$ & $\begin{array}{r}9.5 \\
8.5 \\
9.0 \\
9.0 \\
10.0\end{array}$ & $\begin{array}{l}6.0 \\
6.5 \\
8.0 \\
6.0 \\
4.0\end{array}$ & $\begin{array}{l}3.0 \\
6.0 \\
6.0 \\
3.5 \\
3.5\end{array}$ & $\begin{array}{l}4.5 \\
6.5 \\
7.0 \\
4.5 \\
3.5\end{array}$ & $\begin{array}{l}4.5 \\
3.0 \\
4.5 \\
4.5 \\
5.0\end{array}$ & $\begin{array}{l}2.5 \\
1.5 \\
2.0 \\
3.5 \\
3.0\end{array}$ & $\begin{array}{l}3.0 \\
2.0 \\
3.5 \\
4.0 \\
4.0\end{array}$ & $=$ & $=$ & $=$ \\
\hline $\begin{array}{l}21 \\
22 \\
23 \\
24 \\
25\end{array}$ & $\begin{array}{l}13.5 \\
12.0 \\
11.0 \\
10.0 \\
11.0\end{array}$ & $\begin{array}{r}9.5 \\
11.0 \\
8.5 \\
6.5 \\
9.5\end{array}$ & $\begin{array}{r}11.5 \\
11.5 \\
10.0 \\
8.5 \\
10.0\end{array}$ & $\begin{array}{l}4.5 \\
4.0 \\
6.0 \\
5.5 \\
4.0\end{array}$ & $\begin{array}{l}3.0 \\
2.5 \\
3.0 \\
3.0 \\
2.0\end{array}$ & $\begin{array}{l}3.5 \\
3.5 \\
4.5 \\
4.0 \\
3.0\end{array}$ & $\begin{array}{l}3.0 \\
3.5 \\
4.5 \\
4.5 \\
2.5\end{array}$ & $\begin{array}{l}1.0 \\
2.0 \\
2.0 \\
2.0 \\
1.0\end{array}$ & $\begin{array}{l}2.0 \\
2.5 \\
3.5 \\
4.0 \\
2.0\end{array}$ & $\begin{array}{l}1.0 \\
2.0 \\
2.5 \\
1.5 \\
1.0\end{array}$ & $\begin{array}{l}.5 \\
1.0 \\
1.5 \\
1.0 \\
1.0\end{array}$ & $\begin{array}{l}1.0 \\
1.5 \\
2.0 \\
1.0 \\
1.0\end{array}$ \\
\hline $\begin{array}{l}26 \\
27 \\
28 \\
29 \\
30 \\
31\end{array}$ & $\begin{array}{r}10.5 \\
10.5 \\
9.5 \\
10.0 \\
11.0 \\
10.5\end{array}$ & $\begin{array}{l}8.0 \\
7.0 \\
6.5 \\
7.5 \\
8.0 \\
7.5\end{array}$ & $\begin{array}{l}9.5 \\
8.5 \\
8.0 \\
9.0 \\
9.5 \\
9.0\end{array}$ & $\begin{array}{l}5.0 \\
6.0 \\
4.5 \\
6.0 \\
2.5 \\
-. .\end{array}$ & $\begin{array}{l}3.5 \\
4.0 \\
2.0 \\
2.0 \\
1.0 \\
-.0\end{array}$ & $\begin{array}{l}4.0 \\
5.0 \\
2.5 \\
4.0 \\
2.0 \\
.\end{array}$ & $\begin{array}{l}2.0 \\
1.5 \\
2.0 \\
3.0 \\
3.0 \\
1.5\end{array}$ & $\begin{array}{l}1.0 \\
1.0 \\
1.5 \\
2.0 \\
1.5 \\
1.0\end{array}$ & $\begin{array}{l}1.5 \\
1.5 \\
1.5 \\
2.5 \\
2.5 \\
1.0\end{array}$ & $\begin{array}{l}1.5 \\
3.0 \\
3.5 \\
3.0 \\
2.5 \\
2.0\end{array}$ & $\begin{array}{l}1.0 \\
1.5 \\
2.0 \\
1.0 \\
1.0 \\
1.0\end{array}$ & $\begin{array}{l}1.0 \\
2.5 \\
3.0 \\
2.5 \\
1.5 \\
1.5\end{array}$ \\
\hline MONTH & 14.5 & 6.5 & 10.5 & 12.0 & 1.0 & 6.0 & 5.0 & 1.0 & 2.5 & 3.5 & .5 & 1.5 \\
\hline
\end{tabular}


Table 20. Water temperatures of Steiner Branch, 1978 and 1979 water years.

TEMPERATURE, WATER (DEG. C), WATEK YEAR OCTOGER 1978 TO SEPTEMGER 1919

\begin{tabular}{|c|c|c|c|c|c|c|c|c|c|c|c|c|}
\hline \multirow[t]{2}{*}{ DAY } & $\max$ & MIN & MEAN & MAX & MIN & MEAN & $\max$ & MIN & MEAN & $\operatorname{MAX}$ & MIN & MEAN \\
\hline & \multicolumn{3}{|c|}{ FEGRUARY } & \multicolumn{3}{|c|}{ MARCH } & \multicolumn{3}{|c|}{ APRIL } & \multicolumn{3}{|c|}{ MAY } \\
\hline $\begin{array}{l}1 \\
2 \\
3 \\
4 \\
5\end{array}$ & $\begin{array}{l}1.0 \\
2.0 \\
2.0 \\
1.0 \\
1.0\end{array}$ & $\begin{array}{l}1.0 \\
1.0 \\
1.0 \\
1.0 \\
1.0\end{array}$ & $\begin{array}{l}1.0 \\
1.5 \\
1.5 \\
1.0 \\
1.0\end{array}$ & $\begin{array}{l}6.0 \\
5.0 \\
5.0 \\
5.0 \\
5.5\end{array}$ & $\begin{array}{l}3.5 \\
3.5 \\
4.0 \\
3.5 \\
3.0\end{array}$ & $\begin{array}{l}5.0 \\
4.0 \\
4.0 \\
4.0 \\
4.0\end{array}$ & $\begin{array}{l}7.0 \\
6.5 \\
7.0 \\
7.5 \\
7.5\end{array}$ & $\begin{array}{l}6.5 \\
5.5 \\
5.5 \\
6.5 \\
1.5\end{array}$ & $\begin{array}{l}6.5 \\
6.0 \\
6.5 \\
7.0 \\
6.0\end{array}$ & $\begin{array}{l}11.5 \\
10.0 \\
23.0 \\
15.0 \\
14.5\end{array}$ & $\begin{array}{l}5.0 \\
8.0 \\
8.0 \\
6.5 \\
6.5\end{array}$ & $\begin{array}{r}8.5 \\
9.0 \\
11.5 \\
10.5 \\
10.5\end{array}$ \\
\hline $\begin{array}{r}6 \\
7 \\
8 \\
9 \\
10\end{array}$ & 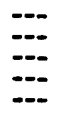 & 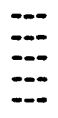 & 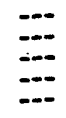 & $\begin{array}{l}6.0 \\
5.0 \\
6.5 \\
6.5 \\
2.0\end{array}$ & $\begin{array}{l}1.5 \\
4.0 \\
3.5 \\
1.5 \\
1.0\end{array}$ & $\begin{array}{l}4.0 \\
4.5 \\
5.0 \\
4.5 \\
1.0\end{array}$ & $\begin{array}{r}4.0 \\
8.5 \\
6.5 \\
7.0 \\
10.0\end{array}$ & $\begin{array}{l}1.0 \\
3.5 \\
4.0 \\
4.5 \\
3.0\end{array}$ & $\begin{array}{l}4.5 \\
5.5 \\
5.5 \\
5.5 \\
6.5\end{array}$ & $\begin{array}{l}22.5 \\
16.5 \\
19.0 \\
21.5 \\
22.0\end{array}$ & $\begin{array}{r}9.0 \\
10.0 \\
10.5 \\
12.0 \\
12.5\end{array}$ & $\begin{array}{l}13.0 \\
13.0 \\
15.0 \\
16.5 \\
17.0\end{array}$ \\
\hline $\begin{array}{l}11 \\
12 \\
13 \\
14 \\
15\end{array}$ & $\begin{array}{l}---5 \\
1.0 \\
2.5 \\
2.5 \\
2.5\end{array}$ & $\begin{array}{l}.5 \\
1.0 \\
1.0 \\
2.0\end{array}$ & $\begin{array}{l}1.0 \\
1.0 \\
2.0 \\
2.5\end{array}$ & $\begin{array}{l}4.0 \\
6.5 \\
8.5 \\
5.5 \\
5.5\end{array}$ & $\begin{array}{l}1.0 \\
1.0 \\
1.00 \\
1.0\end{array}$ & $\begin{array}{l}2.0 \\
3.0 \\
3.5 \\
2.5\end{array}$ & $\begin{array}{r}6.0 \\
14.5 \\
12.0 \\
11.5 \\
13.5\end{array}$ & $\begin{array}{l}5.0 \\
5.5 \\
7.0 \\
5.0 \\
6.5\end{array}$ & $\begin{array}{r}5.5 \\
10.0 \\
9.0 \\
9.0 \\
9.5\end{array}$ & $\begin{array}{r}10.5 \\
-0 . \\
16.0 \\
18.0\end{array}$ & $\begin{array}{r}15.0 \\
12.0 \\
0.5\end{array}$ & $\begin{array}{r}15.5 \\
-0.0 \\
14.0 \\
13.0\end{array}$ \\
\hline $\begin{array}{l}16 \\
17 \\
18 \\
19 \\
20\end{array}$ & $\begin{array}{l}2.0 \\
1.0 \\
1.0 \\
1.0 \\
--.\end{array}$ & $\begin{array}{l}1.0 \\
1.0 \\
1.0 \\
1.0 \\
-.\end{array}$ & $\begin{array}{l}1.5 \\
1.0 \\
1.0 \\
1.0 \\
-.0\end{array}$ & $\begin{array}{l}7.5 \\
5.5 \\
8.0 \\
4.5 \\
7.0\end{array}$ & $\begin{array}{l}1.0 \\
3.5 \\
3.5 \\
3.0 \\
3.0\end{array}$ & $\begin{array}{l}4.0 \\
5.0 \\
6.0 \\
3.5 \\
4.5\end{array}$ & $\begin{array}{r}14.0 \\
15.0 \\
14.5 \\
9.5 \\
10.5\end{array}$ & $\begin{array}{l}5.0 \\
5.5 \\
6.0 \\
7.5 \\
8.0\end{array}$ & $\begin{array}{r}9.5 \\
10.0 \\
10.5 \\
8.5 \\
9.5\end{array}$ & $\begin{array}{l}18.0 \\
20.0 \\
17.5 \\
20.0 \\
19.0\end{array}$ & $\begin{array}{r}7.5 \\
10.5 \\
13.0 \\
12.5 \\
10.0\end{array}$ & $\begin{array}{l}13.0 \\
15.0 \\
15.5 \\
15.5 \\
14.5\end{array}$ \\
\hline $\begin{array}{l}21 \\
22 \\
23 \\
24 \\
25\end{array}$ & \begin{tabular}{c}
$\ldots$ \\
$\cdots$ \\
\hdashline-5 \\
2.5
\end{tabular} & $\begin{array}{c}=-0 \\
=-5 \\
-5\end{array}$ & $\ddot{\ldots}$ & $\begin{array}{l}7.0 \\
7.5 \\
6.5 \\
5.0 \\
8.0\end{array}$ & $\begin{array}{l}4.0 \\
4.0 \\
5.0 \\
2.5 \\
2.5\end{array}$ & $\begin{array}{l}5.0 \\
6.0 \\
6.0 \\
3.5 \\
4.5\end{array}$ & $\begin{array}{l}15.0 \\
17.0 \\
17.0 \\
12.0 \\
14.5\end{array}$ & $\begin{array}{r}9.0 \\
7.0 \\
7.5 \\
9.5 \\
10.5\end{array}$ & $\begin{array}{l}11.5 \\
11.5 \\
12.5 \\
11.0 \\
12.5\end{array}$ & $\begin{array}{r}17.0 \\
12.5 \\
12.5 \\
9.5 \\
. . .5\end{array}$ & $\begin{array}{l}8.5 \\
8.5 \\
9.5 \\
7.5 \\
-. .\end{array}$ & $\begin{array}{r}12.5 \\
11.0 \\
11.0 \\
8.0 \\
-\ldots\end{array}$ \\
\hline $\begin{array}{l}26 \\
27 \\
28 \\
29 \\
30 \\
31\end{array}$ & $\begin{array}{l}3.0 \\
4.0 \\
4.5 \\
-\ldots . \\
-\cdots \\
-.-\end{array}$ & \begin{tabular}{l}
1.0 \\
1.0 \\
1.0 \\
\hdashline$\ldots$ \\
\hdashline .0
\end{tabular} & $\begin{array}{l}1.5 \\
2.0 \\
3.0 \\
\ldots \ldots \\
\ldots \ldots\end{array}$ & $\begin{array}{l}7.5 \\
9.5 \\
6.5 \\
6.0 \\
8.0 \\
7.5\end{array}$ & $\begin{array}{l}2.0 \\
2.5 \\
4.5 \\
5.5 \\
0.0 \\
7.0\end{array}$ & $\begin{array}{l}4.5 \\
5.5 \\
5.5 \\
6.0 \\
7.0 \\
7.0\end{array}$ & $\begin{array}{r}13.5 \\
=-0 \\
9.5 \\
0-\end{array}$ & $\begin{array}{l}8.5 \\
--.- \\
--.5 \\
7.5 \\
--.\end{array}$ & $\begin{array}{r}10.5 \\
-0.5 \\
0.5 \\
-0 .\end{array}$ & 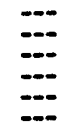 & $=0$ & $\ddot{\square}$ \\
\hline MONTH & 4.5 & .5 & 1.5 & 9.5 & 1.0 & 4.5 & 17.0 & 1.0 & 8.5 & 23.0 & 5.0 & 13.0 \\
\hline
\end{tabular}

TEMPERATURE, WATER (DEG. C), WATER YEAR OCTOBER 1978 TO SEPTEMBER 1979

\begin{tabular}{|c|c|c|c|c|c|c|c|c|c|c|c|c|}
\hline DAY & $\operatorname{mAX}$ & MIN & MEAN & $\operatorname{MAX}$ & MIN & MEAN & $\operatorname{MAX}$ & MIN & MEAN & $\max$ & MIN & MEAN \\
\hline & \multicolumn{3}{|c|}{ JUNE } & \multicolumn{3}{|c|}{ JULY } & \multicolumn{3}{|c|}{ AUGUST } & \multicolumn{3}{|c|}{ SEPTEMBER } \\
\hline $\begin{array}{l}1 \\
2 \\
3 \\
4 \\
5\end{array}$ & $=$ & 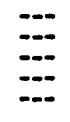 & $\ddot{m}$ & $\begin{array}{l}21.0 \\
21.0 \\
20.5 \\
21.0 \\
19.5\end{array}$ & $\begin{array}{l}13.0 \\
13.0 \\
14.0 \\
15.5 \\
12.5\end{array}$ & $\begin{array}{l}17.0 \\
17.0 \\
17.0 \\
17.5 \\
15.5\end{array}$ & ב- & 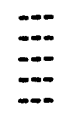 & $\begin{array}{l}-- \\
\cdots \\
\cdots-\end{array}$ & $\begin{array}{l}20.0 \\
19.5 \\
18.0 \\
18.0 \\
18.5\end{array}$ & $\begin{array}{l}16.0 \\
15.0 \\
14.0 \\
13.5 \\
13.5\end{array}$ & $\begin{array}{l}18.0 \\
17.0 \\
16.0 \\
15.5 \\
16.0\end{array}$ \\
\hline $\begin{array}{r}6 \\
7 \\
8 \\
9 \\
10\end{array}$ & $\begin{array}{r}-10 \\
16.5 \\
16.5 \\
15.5\end{array}$ & $\begin{array}{r}-0 . \\
15.0 \\
14.0 \\
12.5\end{array}$ & $\begin{array}{l}-0 . \\
16.0 \\
15.0 \\
14.0\end{array}$ & $\begin{array}{l}18.0 \\
18.5 \\
20.0 \\
20.5 \\
21.0\end{array}$ & $\begin{array}{l}11.5 \\
12.0 \\
12.5 \\
13.0 \\
14.0\end{array}$ & $\begin{array}{l}14.5 \\
15.5 \\
16.0 \\
16.5 \\
17.5\end{array}$ & $\begin{array}{l}20.0 \\
23.0 \\
19.5 \\
21.5 \\
20.5\end{array}$ & $\begin{array}{l}17.5 \\
16.0 \\
17.5 \\
18.5 \\
17.5\end{array}$ & $\begin{array}{l}19.5 \\
19.5 \\
18.5 \\
19.5 \\
19.5\end{array}$ & $\begin{array}{l}18.5 \\
15.5 \\
14.5 \\
16.0 \\
18.0\end{array}$ & $\begin{array}{l}14.5 \\
12.0 \\
10.5 \\
11.5 \\
14.0\end{array}$ & $\begin{array}{l}16.5 \\
13.5 \\
12.5 \\
14.0 \\
16.0\end{array}$ \\
\hline $\begin{array}{l}11 \\
12 \\
13 \\
14 \\
15\end{array}$ & $\begin{array}{l}20.0 \\
20.0 \\
19.0 \\
21.5 \\
29.0\end{array}$ & $\begin{array}{l}10.5 \\
12.5 \\
12.0 \\
13.0 \\
15.0\end{array}$ & $\begin{array}{l}15.0 \\
16.0 \\
16.0 \\
17.0 \\
19.0\end{array}$ & $\begin{array}{l}18.5 \\
21.0 \\
18.0 \\
20.5 \\
21.5\end{array}$ & $\begin{array}{l}15.0 \\
14.5 \\
16.0 \\
15.5 \\
15.0\end{array}$ & $\begin{array}{l}17.0 \\
17.5 \\
16.5 \\
18.5 \\
18.0\end{array}$ & $\begin{array}{l}18.0 \\
18.0 \\
15.5 \\
16.5 \\
16.5\end{array}$ & $\begin{array}{l}14.0 \\
12.5 \\
14.5 \\
12.5 \\
11.0\end{array}$ & $\begin{array}{l}16.0 \\
15.0 \\
15.0 \\
14.5 \\
13.5\end{array}$ & $\begin{array}{l}18.5 \\
17.5 \\
16.5 \\
14.0 \\
14.0\end{array}$ & $\begin{array}{r}14.5 \\
13.5 \\
14.0 \\
11.0 \\
9.5\end{array}$ & $\begin{array}{l}16.0 \\
15.5 \\
15.0 \\
12.5 \\
12.0\end{array}$ \\
\hline $\begin{array}{l}16 \\
17 \\
18 \\
19 \\
20\end{array}$ & $\begin{array}{l}21.0 \\
20.5 \\
16.0 \\
20.5 \\
21.5\end{array}$ & $\begin{array}{l}15.0 \\
15.0 \\
13.0 \\
12.5 \\
15.0\end{array}$ & $\begin{array}{l}18.5 \\
17.5 \\
14.5 \\
16.0 \\
18.5\end{array}$ & $\begin{array}{r}20.0 \\
19.0 \\
16.0 \\
\ldots .0 \\
\ldots .0\end{array}$ & $\begin{array}{r}14.5 \\
14.5 \\
12.0 \\
\ldots \ldots\end{array}$ & $\begin{array}{r}17.5 \\
16.5 \\
13.5 \\
\ldots . .-\end{array}$ & $\begin{array}{l}14.5 \\
18.0 \\
17.5 \\
17.0 \\
18.0\end{array}$ & $\begin{array}{l}11.0 \\
13.5 \\
15.5 \\
14.5 \\
16.0\end{array}$ & $\begin{array}{l}12.5 \\
14.5 \\
16.5 \\
15.5 \\
17.0\end{array}$ & $\begin{array}{l}15.0 \\
15.0 \\
15.5 \\
13.5 \\
15.0\end{array}$ & $\begin{array}{r}10.0 \\
10.0 \\
11.0 \\
10.0 \\
9.5\end{array}$ & $\begin{array}{l}12.0 \\
12.5 \\
13.0 \\
12.0 \\
12.0\end{array}$ \\
\hline $\begin{array}{l}21 \\
22 \\
23 \\
24 \\
25\end{array}$ & $\begin{array}{l}22.5 \\
20.5 \\
17.0 \\
19.5 \\
19.5\end{array}$ & $\begin{array}{l}14.5 \\
13.5 \\
13.0 \\
11.0 \\
10.5\end{array}$ & $\begin{array}{l}18.5 \\
16.5 \\
15.0 \\
15.0 \\
15.0\end{array}$ & 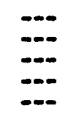 & 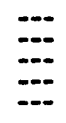 & $=$ & $\begin{array}{l}17.5 \\
18.5 \\
17.5 \\
16.0 \\
17.0\end{array}$ & $\begin{array}{l}15.0 \\
15.0 \\
14.5 \\
12.5 \\
12.5\end{array}$ & $\begin{array}{l}16.0 \\
16.5 \\
16.0 \\
14.5 \\
14.5\end{array}$ & $\begin{array}{l}14.5 \\
12.5 \\
12.5 \\
12.0 \\
14.0\end{array}$ & $\begin{array}{r}11.5 \\
9.0 \\
8.5 \\
10.0 \\
10.5\end{array}$ & $\begin{array}{l}13.0 \\
10.5 \\
10.5 \\
11.0 \\
12.0\end{array}$ \\
\hline $\begin{array}{l}26 \\
27 \\
28 \\
29 \\
30 \\
31\end{array}$ & $\begin{array}{l}21.0 \\
19.5 \\
19.5 \\
17.5 \\
21.0 \\
\ldots\end{array}$ & $\begin{array}{l}11.5 \\
14.5 \\
13.5 \\
14.5 \\
13.0 \\
0.0\end{array}$ & $\begin{array}{r}16.0 \\
17.0 \\
16.5 \\
16.0 \\
16.5 \\
-\end{array}$ & ב- & 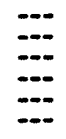 & $\ddot{-\infty}$ & $\begin{array}{l}18.0 \\
18.0 \\
17.5 \\
19.0 \\
19.0 \\
19.0\end{array}$ & $\begin{array}{l}13.5 \\
15.0 \\
14.0 \\
13.0 \\
14.0 \\
14.5\end{array}$ & $\begin{array}{l}15.5 \\
16.0 \\
15.5 \\
11.0 \\
16.5 \\
17.0\end{array}$ & $\begin{array}{r}14.5 \\
14.5 \\
15.0 \\
15.0 \\
14.5 \\
-. .5\end{array}$ & $\begin{array}{l}10.0 \\
10.5 \\
10.5 \\
12.0 \\
12.0 \\
-\end{array}$ & $\begin{array}{r}12.0 \\
12.5 \\
12.5 \\
13.5 \\
13.0 \\
-. .\end{array}$ \\
\hline MONTH & 23.0 & 10.5 & 16.5 & 21.5 & 11.5 & 16.5 & 23.0 & 11.0 & 16.0 & 20.0 & 8.5 & 13.5 \\
\hline YEAR & 23.0 & .5 & 9.5 & & & & & & & & & \\
\hline
\end{tabular}


Table 21. Specific conductance of Steiner Branch, 1978 and 1979 water years.

SPECIFIC CONOUCTANCF (MICROMHOS/CM AT 25 DEG. C), WATER YEAR OCTOBER 1977 TO SEPTEMBER 1978

\begin{tabular}{|c|c|c|c|c|c|c|c|c|c|c|c|c|}
\hline \multirow[t]{2}{*}{ DAY } & $\operatorname{MAX}$ & $M I N$ & MEAN & MAX & MIN & MEAN & $\max$ & MIN & MEAN & $\max$ & MIN & MEAN \\
\hline & \multicolumn{3}{|c|}{ OCTUAER } & \multicolumn{3}{|c|}{ NOVFMAER } & \multicolumn{3}{|c|}{ DECEMBER } & \multicolumn{3}{|c|}{ JANUARY } \\
\hline $\begin{array}{l}1 \\
2 \\
3 \\
4 \\
5\end{array}$ & $\begin{array}{l}--- \\
=- \\
\because-- \\
--\end{array}$ & $\begin{array}{l}m-- \\
\overline{--} \\
\cdots-\end{array}$ & $=$ & $\begin{array}{l}577 \\
591 \\
591 \\
588 \\
577\end{array}$ & $\begin{array}{l}564 \\
561 \\
588 \\
559 \\
569\end{array}$ & $\begin{array}{l}572 \\
579 \\
591 \\
579 \\
573\end{array}$ & $\begin{array}{l}551 \\
559 \\
585 \\
591 \\
559\end{array}$ & $\begin{array}{l}540 \\
548 \\
559 \\
556 \\
537\end{array}$ & $\begin{array}{l}546 \\
553 \\
574 \\
572 \\
550\end{array}$ & $\begin{array}{l}526 \\
551 \\
548 \\
540 \\
523\end{array}$ & $\begin{array}{l}513 \\
528 \\
528 \\
513 \\
515\end{array}$ & $\begin{array}{l}516 \\
539 \\
539 \\
525 \\
520\end{array}$ \\
\hline $\begin{array}{r}6 \\
7 \\
8 \\
9 \\
10\end{array}$ & $\begin{array}{l}--- \\
=- \\
--- \\
---\end{array}$ & $\begin{array}{l}\ldots- \\
\cdots- \\
\cdots- \\
\cdots-\end{array}$ & 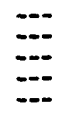 & $\begin{array}{l}572 \\
588 \\
588 \\
588 \\
580\end{array}$ & $\begin{array}{l}551 \\
569 \\
582 \\
577 \\
572\end{array}$ & $\begin{array}{l}565 \\
579 \\
587 \\
582 \\
575\end{array}$ & $\begin{array}{l}597 \\
607 \\
564 \\
572 \\
569\end{array}$ & $\begin{array}{l}548 \\
561 \\
543 \\
551 \\
551\end{array}$ & $\begin{array}{l}575 \\
585 \\
553 \\
564 \\
562\end{array}$ & $\begin{array}{l}526 \\
526 \\
561 \\
588 \\
572\end{array}$ & $\begin{array}{l}517 \\
521 \\
521 \\
561 \\
543\end{array}$ & $\begin{array}{l}522 \\
524 \\
533 \\
575 \\
558\end{array}$ \\
\hline $\begin{array}{l}11 \\
12 \\
13 \\
14 \\
15\end{array}$ & 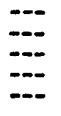 & $\overline{-}$ & $=$ & $\begin{array}{l}574 \\
569 \\
566 \\
566 \\
574\end{array}$ & $\begin{array}{l}564 \\
561 \\
561 \\
561 \\
566\end{array}$ & $\begin{array}{l}570 \\
567 \\
564 \\
565 \\
570\end{array}$ & $\begin{array}{l}569 \\
556 \\
545 \\
561 \\
564\end{array}$ & $\begin{array}{l}551 \\
543 \\
523 \\
548 \\
553\end{array}$ & $\begin{array}{l}559 \\
551 \\
532 \\
554 \\
560\end{array}$ & $\begin{array}{l}553 \\
540 \\
508 \\
504 \\
517\end{array}$ & $\begin{array}{l}528 \\
508 \\
497 \\
497 \\
506\end{array}$ & $\begin{array}{l}542 \\
524 \\
503 \\
501 \\
513\end{array}$ \\
\hline $\begin{array}{l}16 \\
17 \\
18 \\
19 \\
20\end{array}$ & 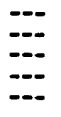 & 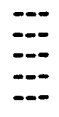 & $=-$ & $\begin{array}{l}574 \\
572 \\
572 \\
569 \\
572\end{array}$ & $\begin{array}{l}569 \\
566 \\
564 \\
564 \\
564\end{array}$ & $\begin{array}{l}572 \\
568 \\
568 \\
567 \\
568\end{array}$ & $\begin{array}{l}564 \\
566 \\
574 \\
580 \\
569\end{array}$ & $\begin{array}{l}559 \\
508 \\
532 \\
572 \\
548\end{array}$ & $\begin{array}{l}563 \\
536 \\
558 \\
577 \\
556\end{array}$ & $\begin{array}{l}519 \\
519 \\
519 \\
515 \\
515\end{array}$ & $\begin{array}{l}513 \\
513 \\
510 \\
508 \\
510\end{array}$ & $\begin{array}{l}516 \\
516 \\
515 \\
513 \\
513\end{array}$ \\
\hline $\begin{array}{l}21 \\
22 \\
23 \\
24 \\
25\end{array}$ & $\begin{array}{l}\cdots \\
\cdots \\
-0 \\
569\end{array}$ & 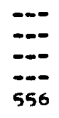 & 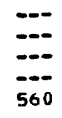 & $\begin{array}{l}566 \\
564 \\
566 \\
566 \\
577\end{array}$ & $\begin{array}{l}561 \\
561 \\
537 \\
556 \\
545\end{array}$ & $\begin{array}{l}564 \\
563 \\
550 \\
560 \\
558\end{array}$ & $\begin{array}{l}559 \\
566 \\
561 \\
561 \\
597\end{array}$ & $\begin{array}{l}\mathbf{5 5 3} \\
559 \\
553 \\
543 \\
556\end{array}$ & $\begin{array}{l}557 \\
563 \\
558 \\
555 \\
583\end{array}$ & $\begin{array}{l}517 \\
523 \\
517 \\
517 \\
561\end{array}$ & $\begin{array}{l}513 \\
510 \\
510 \\
508 \\
548\end{array}$ & $\begin{array}{l}515 \\
518 \\
515 \\
515 \\
555\end{array}$ \\
\hline $\begin{array}{l}26 \\
27 \\
28 \\
29 \\
30 \\
31\end{array}$ & $\begin{array}{l}564 \\
545 \\
543 \\
540 \\
540 \\
572\end{array}$ & $\begin{array}{l}\mathbf{5 4 5} \\
\mathbf{5 3 7} \\
\mathbf{5 3 5} \\
\mathbf{5 3 2} \\
\mathbf{5 2 3} \\
\mathbf{5 2 6}\end{array}$ & $\begin{array}{l}558 \\
542 \\
539 \\
537 \\
532 \\
549\end{array}$ & $\begin{array}{l}619 \\
585 \\
559 \\
577 \\
572 \\
---\end{array}$ & $\begin{array}{l}580 \\
543 \\
545 \\
545 \\
545 \\
---\end{array}$ & $\begin{array}{l}599 \\
558 \\
554 \\
562 \\
559 \\
---\end{array}$ & $\begin{array}{l}597 \\
574 \\
559 \\
526 \\
523 \\
528\end{array}$ & $\begin{array}{l}559 \\
553 \\
523 \\
513 \\
515 \\
510\end{array}$ & $\begin{array}{l}574 \\
564 \\
537 \\
519 \\
521 \\
522\end{array}$ & $\begin{array}{l}553 \\
566 \\
566 \\
572 \\
574 \\
561\end{array}$ & $\begin{array}{l}532 \\
551 \\
548 \\
551 \\
543 \\
543\end{array}$ & $\begin{array}{l}547 \\
559 \\
560 \\
563 \\
559 \\
554\end{array}$ \\
\hline MONTH & 572 & 523 & 545 & 619 & 537 & 570 & 607 & 508 & 556 & 588 & 497 & 531 \\
\hline
\end{tabular}

SPECIFIC CONOUCTANCF (MICROMHOS/CM AT 25 OEG. Cr, WATER YEAR OCTOBER 1977 TO SEPTEMBER 1978

\begin{tabular}{|c|c|c|c|c|c|c|c|c|c|c|c|c|}
\hline \multirow[t]{2}{*}{ DAY } & $\max$ & MIN & MEAN & $\max$ & MIN & ME AN & $\max$ & MIN & MEAN & $\max$ & MIN & MEAN \\
\hline & \multicolumn{3}{|c|}{ FEBRUARY } & \multicolumn{3}{|c|}{ MARCH } & \multicolumn{3}{|c|}{ APR IL } & \multicolumn{3}{|c|}{ MaY } \\
\hline $\begin{array}{l}1 \\
2 \\
3 \\
4 \\
5\end{array}$ & $\begin{array}{l}561 \\
551 \\
551 \\
556 \\
548\end{array}$ & $\begin{array}{l}537 \\
540 \\
535 \\
540 \\
543\end{array}$ & $\begin{array}{l}550 \\
546 \\
547 \\
548 \\
547\end{array}$ & $\begin{array}{l}548 \\
551 \\
548 \\
574 \\
577\end{array}$ & $\begin{array}{l}523 \\
523 \\
526 \\
535 \\
532\end{array}$ & $\begin{array}{l}534 \\
535 \\
536 \\
551 \\
553\end{array}$ & $\begin{array}{l}535 \\
530 \\
532 \\
530 \\
526\end{array}$ & $\begin{array}{l}521 \\
513 \\
513 \\
513 \\
461\end{array}$ & $\begin{array}{l}530 \\
521 \\
526 \\
523 \\
514\end{array}$ & $\begin{array}{l}\mathbf{5 5 1} \\
\mathbf{5 5 3} \\
\mathbf{5 8 6} \\
\mathbf{5 5 3} \\
\mathbf{5 5 5}\end{array}$ & $\begin{array}{l}525 \\
525 \\
499 \\
517 \\
534\end{array}$ & $\begin{array}{l}537 \\
539 \\
538 \\
535 \\
545\end{array}$ \\
\hline $\begin{array}{r}6 \\
7 \\
8 \\
9 \\
10\end{array}$ & $\begin{array}{l}564 \\
561 \\
551 \\
548 \\
566\end{array}$ & $\begin{array}{l}540 \\
535 \\
535 \\
535 \\
535\end{array}$ & $\begin{array}{l}554 \\
550 \\
544 \\
543 \\
551\end{array}$ & $\begin{array}{l}548 \\
553 \\
556 \\
561 \\
548\end{array}$ & $\begin{array}{l}528 \\
530 \\
530 \\
528 \\
523\end{array}$ & $\begin{array}{l}539 \\
539 \\
540 \\
541 \\
535\end{array}$ & $\begin{array}{l}530 \\
553 \\
556 \\
561 \\
547\end{array}$ & $\begin{array}{l}412 \\
528 \\
542 \\
517 \\
505\end{array}$ & $\begin{array}{l}481 \\
540 \\
550 \\
549 \\
531\end{array}$ & $\begin{array}{l}550 \\
565 \\
562 \\
564 \\
561\end{array}$ & $\begin{array}{l}515 \\
536 \\
528 \\
543 \\
528\end{array}$ & $\begin{array}{l}537 \\
555 \\
546 \\
554 \\
547\end{array}$ \\
\hline $\begin{array}{l}11 \\
12 \\
13 \\
14 \\
15\end{array}$ & $\begin{array}{l}564 \\
548 \\
551 \\
559 \\
551\end{array}$ & $\begin{array}{l}532 \\
535 \\
535 \\
537 \\
535\end{array}$ & $\begin{array}{l}549 \\
543 \\
544 \\
546 \\
544\end{array}$ & $\begin{array}{l}535 \\
540 \\
548 \\
543 \\
545\end{array}$ & $\begin{array}{l}517 \\
526 \\
528 \\
526 \\
530\end{array}$ & $\begin{array}{l}527 \\
536 \\
540 \\
536 \\
537\end{array}$ & $\begin{array}{l}552 \\
555 \\
552 \\
549 \\
551\end{array}$ & $\begin{array}{l}537 \\
520 \\
518 \\
514 \\
504\end{array}$ & $\begin{array}{l}546 \\
543 \\
540 \\
537 \\
535\end{array}$ & $\begin{array}{l}561 \\
548 \\
432 \\
477 \\
497\end{array}$ & $\begin{array}{l}517 \\
464 \\
271 \\
385 \\
485\end{array}$ & $\begin{array}{l}545 \\
531 \\
381 \\
453 \\
492\end{array}$ \\
\hline $\begin{array}{l}16 \\
17 \\
18 \\
19 \\
20\end{array}$ & $\begin{array}{l}559 \\
566 \\
566 \\
561 \\
551\end{array}$ & $\begin{array}{l}\mathbf{5 3 5} \\
532 \\
526 \\
526 \\
526\end{array}$ & $\begin{array}{l}546 \\
550 \\
548 \\
544 \\
539\end{array}$ & $\begin{array}{l}551 \\
551 \\
548 \\
530 \\
-\end{array}$ & $\begin{array}{l}532 \\
532 \\
506 \\
404 \\
-.-\end{array}$ & $\begin{array}{l}540 \\
542 \\
537 \\
513 \\
---\end{array}$ & $\begin{array}{l}549 \\
547 \\
537 \\
539 \\
544\end{array}$ & $\begin{array}{l}502 \\
515 \\
486 \\
530 \\
522\end{array}$ & $\begin{array}{l}532 \\
536 \\
515 \\
536 \\
535\end{array}$ & $\begin{array}{l}505 \\
517 \\
527 \\
584 \\
572\end{array}$ & $\begin{array}{l}502 \\
508 \\
512 \\
470 \\
543\end{array}$ & $\begin{array}{l}504 \\
512 \\
519 \\
505 \\
562\end{array}$ \\
\hline $\begin{array}{l}21 \\
22 \\
23 \\
24 \\
25\end{array}$ & $\begin{array}{l}559 \\
561 \\
537 \\
537 \\
537\end{array}$ & $\begin{array}{l}526 \\
523 \\
519 \\
526 \\
526\end{array}$ & $\begin{array}{l}541 \\
542 \\
532 \\
532 \\
532\end{array}$ & $\begin{array}{l}424 \\
434 \\
412 \\
458 \\
486\end{array}$ & $\begin{array}{l}255 \\
309 \\
343 \\
433 \\
478\end{array}$ & $\begin{array}{l}342 \\
372 \\
390 \\
447 \\
483\end{array}$ & $\begin{array}{l}546 \\
546 \\
544 \\
549 \\
549\end{array}$ & $\begin{array}{l}522 \\
520 \\
527 \\
527 \\
512\end{array}$ & $\begin{array}{l}534 \\
535 \\
537 \\
539 \\
535\end{array}$ & $\begin{array}{l}567 \\
566 \\
588 \\
591 \\
590\end{array}$ & $\begin{array}{l}530 \\
536 \\
577 \\
546 \\
537\end{array}$ & $\begin{array}{l}556 \\
557 \\
584 \\
577 \\
571\end{array}$ \\
\hline $\begin{array}{l}26 \\
27 \\
28 \\
29 \\
30 \\
31\end{array}$ & $\begin{array}{l}543 \\
545 \\
537 \\
--- \\
--0 \\
---\end{array}$ & \begin{tabular}{l}
528 \\
528 \\
523 \\
--0 \\
\hdashline-0
\end{tabular} & $\begin{array}{l}535 \\
536 \\
532 \\
\ldots-- \\
\ldots-\end{array}$ & $\begin{array}{l}522 \\
541 \\
543 \\
545 \\
545 \\
540\end{array}$ & $\begin{array}{l}506 \\
533 \\
535 \\
537 \\
532 \\
523\end{array}$ & $\begin{array}{l}515 \\
535 \\
539 \\
541 \\
539 \\
533\end{array}$ & $\begin{array}{l}549 \\
554 \\
552 \\
548 \\
553 \\
---\end{array}$ & $\begin{array}{l}515 \\
517 \\
506 \\
518 \\
518 \\
-\end{array}$ & $\begin{array}{l}534 \\
536 \\
532 \\
536 \\
540 \\
---\end{array}$ & $\begin{array}{l}588 \\
584 \\
576 \\
602 \\
582 \\
574\end{array}$ & $\begin{array}{l}535 \\
494 \\
489 \\
543 \\
553 \\
551\end{array}$ & $\begin{array}{l}566 \\
558 \\
554 \\
566 \\
572 \\
566\end{array}$ \\
\hline MONTH & 566 & 519 & 543 & 577 & 255 & 515 & 561 & 412 & 533 & 602 & 271 & 538 \\
\hline
\end{tabular}


Table 21. Specific conductance of Steiner Branch, 1978 and 1979 water years.

SPECIFIC CONDUCTANCE IMICROMHOS/CM AT 25 DFG. CI, WATER YEAR OCTOBER 1977 TO SEPTEMBER 1978

\begin{tabular}{|c|c|c|c|c|c|c|c|c|c|c|c|c|}
\hline \multirow[t]{2}{*}{ DAY } & $\max$ & MIN & MEAN & $\max$ & MIN & MEAN & $\max$ & MIN & MEAN & $\max$ & MIN & MEAN \\
\hline & \multicolumn{3}{|c|}{ JUNE } & \multicolumn{3}{|c|}{ JULY } & \multicolumn{3}{|c|}{ AUGUST } & \multicolumn{3}{|c|}{ SEPTEMBER } \\
\hline $\begin{array}{l}1 \\
2 \\
3 \\
4 \\
5\end{array}$ & $\begin{array}{l}588 \\
572 \\
561 \\
580 \\
580\end{array}$ & $\begin{array}{l}559 \\
551 \\
545 \\
548 \\
564\end{array}$ & $\begin{array}{l}569 \\
565 \\
555 \\
558 \\
570\end{array}$ & $\begin{array}{l}569 \\
601 \\
597 \\
591 \\
577\end{array}$ & $\begin{array}{l}149 \\
577 \\
591 \\
577 \\
564\end{array}$ & $\begin{array}{l}427 \\
598 \\
595 \\
584 \\
572\end{array}$ & $\begin{array}{l}620 \\
\cdots \\
\cdots-\end{array}$ & \begin{tabular}{l}
506 \\
\hdashline-- \\
\hdashline- \\
\hdashline-
\end{tabular} & \begin{tabular}{c}
594 \\
\hdashline-0 \\
\hdashline-0 \\
\hdashline-0
\end{tabular} & $\begin{array}{l}528 \\
523 \\
521 \\
517 \\
513\end{array}$ & $\begin{array}{l}517 \\
515 \\
510 \\
508 \\
506\end{array}$ & $\begin{array}{l}524 \\
519 \\
517 \\
514 \\
509\end{array}$ \\
\hline $\begin{array}{r}6 \\
7 \\
8 \\
9 \\
10\end{array}$ & $\begin{array}{l}577 \\
573 \\
565 \\
563 \\
561\end{array}$ & $\begin{array}{l}556 \\
541 \\
549 \\
542 \\
547\end{array}$ & $\begin{array}{l}568 \\
561 \\
558 \\
557 \\
555\end{array}$ & \begin{tabular}{l}
566 \\
591 \\
\hdashline-0 \\
$\cdots-0$
\end{tabular} & $\begin{array}{l}115 \\
360 \\
--- \\
--0\end{array}$ & \begin{tabular}{l}
451 \\
538 \\
-0 \\
\hdashline-0 \\
--
\end{tabular} & $\ddot{m}$ & 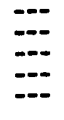 & 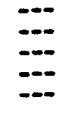 & $\begin{array}{l}510 \\
508 \\
582 \\
574 \\
564\end{array}$ & $\begin{array}{l}502 \\
500 \\
502 \\
564 \\
553\end{array}$ & $\begin{array}{l}506 \\
504 \\
526 \\
571 \\
560\end{array}$ \\
\hline $\begin{array}{l}11 \\
12 \\
13 \\
14 \\
15\end{array}$ & $\begin{array}{l}598 \\
593 \\
583 \\
578 \\
579\end{array}$ & $\begin{array}{l}553 \\
577 \\
573 \\
570 \\
565\end{array}$ & $\begin{array}{l}575 \\
587 \\
579 \\
575 \\
574\end{array}$ & $\ddot{m}$ & $\ddot{m}$ & $\ddot{m}$ & $\ddot{m}$ & 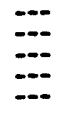 & $\ddot{a-}$ & $\begin{array}{l}553 \\
543 \\
532 \\
523 \\
535\end{array}$ & $\begin{array}{l}\mathbf{5 4 3} \\
535 \\
504 \\
500 \\
521\end{array}$ & $\begin{array}{l}550 \\
538 \\
513 \\
513 \\
528\end{array}$ \\
\hline $\begin{array}{l}16 \\
17 \\
18 \\
19 \\
20\end{array}$ & $\begin{array}{l}576 \\
552 \\
593 \\
611 \\
582\end{array}$ & $\begin{array}{l}285 \\
173 \\
563 \\
560 \\
577\end{array}$ & $\begin{array}{l}488 \\
327 \\
584 \\
589 \\
580\end{array}$ & $\begin{array}{l}-0 \\
-0 \\
588 \\
579\end{array}$ & 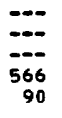 & $\begin{array}{l}-0 \\
571 \\
-5\end{array}$ & 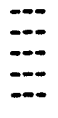 & $\ddot{-\infty}$ & $\ddot{a-}$ & $\begin{array}{l}530 \\
526 \\
493 \\
530 \\
526\end{array}$ & $\begin{array}{l}526 \\
476 \\
267 \\
497 \\
396\end{array}$ & $\begin{array}{l}528 \\
519 \\
404 \\
520 \\
459\end{array}$ \\
\hline $\begin{array}{l}21 \\
22 \\
23 \\
24 \\
25\end{array}$ & $\begin{array}{l}577 \\
572 \\
561 \\
556 \\
548\end{array}$ & $\begin{array}{l}569 \\
561 \\
556 \\
545 \\
176\end{array}$ & $\begin{array}{l}574 \\
567 \\
560 \\
552 \\
413\end{array}$ & $\begin{array}{l}579 \\
612 \\
621 \\
622 \\
610\end{array}$ & $\begin{array}{l}370 \\
571 \\
617 \\
605 \\
602\end{array}$ & $\begin{array}{l}510 \\
606 \\
620 \\
617 \\
604\end{array}$ & $\overline{-0}$ & 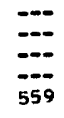 & $\ddot{-a}$ & $\begin{array}{l}532 \\
540 \\
535 \\
535 \\
530\end{array}$ & $\begin{array}{l}495 \\
528 \\
530 \\
528 \\
521\end{array}$ & $\begin{array}{l}521 \\
535 \\
533 \\
530 \\
526\end{array}$ \\
\hline $\begin{array}{l}26 \\
27 \\
28 \\
29 \\
30 \\
31\end{array}$ & $\begin{array}{l}585 \\
577 \\
564 \\
553 \\
543 \\
---\end{array}$ & $\begin{array}{l}508 \\
564 \\
553 \\
540 \\
425 \\
-\end{array}$ & $\begin{array}{l}569 \\
574 \\
559 \\
548 \\
488 \\
-\cdots\end{array}$ & $\begin{array}{l}609 \\
616 \\
613 \\
609 \\
600 \\
597\end{array}$ & $\begin{array}{l}486 \\
592 \\
599 \\
593 \\
590 \\
378\end{array}$ & $\begin{array}{l}571 \\
611 \\
608 \\
603 \\
597 \\
538\end{array}$ & $\begin{array}{l}559 \\
548 \\
532 \\
528 \\
537 \\
532\end{array}$ & $\begin{array}{l}548 \\
530 \\
343 \\
364 \\
528 \\
526\end{array}$ & $\begin{array}{l}554 \\
532 \\
495 \\
473 \\
532 \\
530\end{array}$ & $\begin{array}{l}526 \\
528 \\
521 \\
519 \\
515 \\
---\end{array}$ & $\begin{array}{l}519 \\
519 \\
515 \\
513 \\
513 \\
-\end{array}$ & $\begin{array}{l}522 \\
523 \\
518 \\
515 \\
514 \\
-\end{array}$ \\
\hline MONTH & 611 & 173 & 549 & 622 & 90 & 562 & 620 & 343 & 534 & 582 & 267 & 519 \\
\hline
\end{tabular}

SPECIFIC CONOUCTANCE (MICROMHOS/CM AT 25 DEG. C), WATER YEAR OCTOBER 1978 TO SEPTEMBER 1979

\begin{tabular}{|c|c|c|c|c|c|c|c|c|c|c|c|c|}
\hline \multirow[t]{2}{*}{ DAY } & $\operatorname{Max}$ & MIN & MEAN & $\max$ & MIN & MEAN & $\max$ & MIN & MEAN & $\operatorname{MAX}$ & MIN & MEAN \\
\hline & \multicolumn{3}{|c|}{ OCTOBER } & \multicolumn{3}{|c|}{ NOVEMBER } & \multicolumn{3}{|c|}{ DECEMBER } & \multicolumn{3}{|c|}{ JANUARY } \\
\hline $\begin{array}{l}1 \\
2 \\
3 \\
4 \\
5\end{array}$ & $\begin{array}{l}600 \\
595 \\
591 \\
596 \\
591\end{array}$ & $\begin{array}{l}593 \\
585 \\
585 \\
589 \\
587\end{array}$ & $\begin{array}{l}596 \\
591 \\
589 \\
592 \\
588\end{array}$ & $\begin{array}{l}549 \\
552 \\
553 \\
554 \\
553\end{array}$ & $\begin{array}{l}546 \\
547 \\
548 \\
547 \\
548\end{array}$ & $\begin{array}{l}548 \\
550 \\
551 \\
550 \\
551\end{array}$ & $\begin{array}{l}563 \\
560 \\
555 \\
556 \\
565\end{array}$ & $\begin{array}{l}557 \\
554 \\
544 \\
545 \\
557\end{array}$ & $\begin{array}{l}561 \\
558 \\
549 \\
550 \\
561\end{array}$ & $\begin{array}{l}563 \\
560 \\
-\cdots \\
--0 \\
\cdots\end{array}$ & $\begin{array}{l}554 \\
554 \\
-- \\
-\end{array}$ & $\begin{array}{r}558 \\
556 \\
-0- \\
-\cdots\end{array}$ \\
\hline $\begin{array}{r}6 \\
7 \\
8 \\
9 \\
10\end{array}$ & $\begin{array}{l}596 \\
592 \\
592 \\
590 \\
598\end{array}$ & $\begin{array}{l}592 \\
587 \\
585 \\
585 \\
588\end{array}$ & $\begin{array}{l}593 \\
590 \\
588 \\
586 \\
593\end{array}$ & $\begin{array}{l}554 \\
548 \\
551 \\
552 \\
551\end{array}$ & $\begin{array}{l}545 \\
544 \\
547 \\
550 \\
549\end{array}$ & $\begin{array}{l}549 \\
546 \\
548 \\
550 \\
550\end{array}$ & $\begin{array}{l}-56 \\
563 \\
562 \\
565 \\
577\end{array}$ & $\begin{array}{l}500 \\
500 \\
560 \\
561 \\
557\end{array}$ & $\begin{array}{l}-56 \\
561 \\
560 \\
563 \\
568\end{array}$ & $\ddot{-\infty}$ & $\begin{array}{l}\ldots- \\
\cdots \\
\cdots \\
\cdots-\end{array}$ & $\begin{array}{l}-\ldots \\
-\cdots \\
\cdots \\
-\cdots\end{array}$ \\
\hline $\begin{array}{l}11 \\
12 \\
13 \\
14 \\
15\end{array}$ & $\begin{array}{l}601 \\
642 \\
595 \\
585 \\
580\end{array}$ & $\begin{array}{l}596 \\
553 \\
584 \\
579 \\
575\end{array}$ & $\begin{array}{l}599 \\
596 \\
589 \\
583 \\
579\end{array}$ & $\begin{array}{l}552 \\
551 \\
548 \\
553 \\
556\end{array}$ & $\begin{array}{l}550 \\
547 \\
526 \\
538 \\
550\end{array}$ & $\begin{array}{l}551 \\
549 \\
535 \\
547 \\
554\end{array}$ & $\begin{array}{l}576 \\
598 \\
571 \\
578 \\
577\end{array}$ & $\begin{array}{l}567 \\
536 \\
566 \\
570 \\
569\end{array}$ & $\begin{array}{l}571 \\
568 \\
569 \\
574 \\
573\end{array}$ & 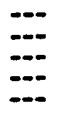 & $\ddot{-\infty}$ & $\begin{array}{l}\cdots \\
\cdots \\
\cdots\end{array}$ \\
\hline $\begin{array}{l}16 \\
17 \\
18 \\
19 \\
20\end{array}$ & $\begin{array}{l}579 \\
572 \\
573 \\
571 \\
570\end{array}$ & $\begin{array}{l}571 \\
567 \\
568 \\
566 \\
567\end{array}$ & $\begin{array}{l}576 \\
571 \\
571 \\
569 \\
569\end{array}$ & $\begin{array}{l}555 \\
556 \\
553 \\
554 \\
555\end{array}$ & $\begin{array}{l}548 \\
493 \\
522 \\
549 \\
552\end{array}$ & $\begin{array}{l}552 \\
516 \\
542 \\
552 \\
554\end{array}$ & $\begin{array}{l}576 \\
575 \\
574 \\
573 \\
572\end{array}$ & $\begin{array}{l}568 \\
570 \\
569 \\
570 \\
567\end{array}$ & $\begin{array}{l}572 \\
571 \\
572 \\
572 \\
571\end{array}$ & $\begin{array}{l}\cdots \\
\cdots \\
\cdots \\
\cdots-\end{array}$ & $\ddot{-\infty}$ & $\ddot{-0}$ \\
\hline $\begin{array}{l}21 \\
22 \\
23 \\
24 \\
25\end{array}$ & $\begin{array}{l}571 \\
569 \\
567 \\
563 \\
567\end{array}$ & $\begin{array}{l}560 \\
564 \\
557 \\
558 \\
564\end{array}$ & $\begin{array}{l}567 \\
567 \\
563 \\
560 \\
566\end{array}$ & $\begin{array}{l}558 \\
559 \\
555 \\
559 \\
557\end{array}$ & $\begin{array}{l}553 \\
552 \\
551 \\
552 \\
549\end{array}$ & $\begin{array}{l}557 \\
557 \\
554 \\
554 \\
554\end{array}$ & $\begin{array}{l}571 \\
573 \\
574 \\
571 \\
572\end{array}$ & $\begin{array}{l}568 \\
567 \\
566 \\
563 \\
562\end{array}$ & $\begin{array}{l}569 \\
570 \\
570 \\
568 \\
568\end{array}$ & $\begin{array}{l}557 \\
563 \\
567 \\
575 \\
581\end{array}$ & $\begin{array}{l}487 \\
559 \\
562 \\
564 \\
577\end{array}$ & $\begin{array}{l}555 \\
561 \\
565 \\
570 \\
579\end{array}$ \\
\hline $\begin{array}{l}26 \\
27 \\
28 \\
29 \\
30 \\
31\end{array}$ & $\begin{array}{l}568 \\
561 \\
556 \\
555 \\
556 \\
554\end{array}$ & $\begin{array}{l}\mathbf{5 5 4} \\
\mathbf{5 5 5} \\
\mathbf{5 5 1} \\
\mathbf{5 5 0} \\
\mathbf{5 5 1} \\
\mathbf{5 4 8}\end{array}$ & $\begin{array}{l}561 \\
557 \\
554 \\
553 \\
553 \\
551\end{array}$ & $\begin{array}{l}561 \\
559 \\
558 \\
566 \\
558 \\
--\end{array}$ & $\begin{array}{l}558 \\
557 \\
550 \\
555 \\
554 \\
-\infty\end{array}$ & $\begin{array}{l}559 \\
559 \\
553 \\
561 \\
556 \\
-5\end{array}$ & $\begin{array}{l}574 \\
591 \\
567 \\
560 \\
558 \\
561\end{array}$ & $\begin{array}{l}563 \\
565 \\
554 \\
552 \\
553 \\
555\end{array}$ & $\begin{array}{l}567 \\
578 \\
562 \\
558 \\
555 \\
556\end{array}$ & $\begin{array}{l}587 \\
597 \\
628 \\
596 \\
596 \\
623\end{array}$ & $\begin{array}{l}583 \\
589 \\
595 \\
588 \\
589 \\
557\end{array}$ & $\begin{array}{l}584 \\
594 \\
601 \\
594 \\
593 \\
592\end{array}$ \\
\hline MONTH & 642 & 548 & 576 & 566 & 493 & 550 & 598 & 500 & 566 & 628 & 487 & \\
\hline
\end{tabular}


Table 21. Specific conductance of Steiner Branch, 1978 and 1979 water years.

SPFCIFIC CONDUCTANCE IMICROMHOS/CM AT 25 DES. C), WAIER YEAR OCTOBER 1978 TD SEPTEMBER 1979

\begin{tabular}{|c|c|c|c|c|c|c|c|c|c|c|c|c|}
\hline DAY & $\operatorname{Max}$ & MIIN & MEAN & $\operatorname{MAX}$ & MIN & MEAN & MAX & MIN & MEAN & MAX & MIN & MEAN \\
\hline \multicolumn{5}{|c|}{ FEARUARY } & \multicolumn{3}{|c|}{ MARCH } & \multicolumn{3}{|c|}{ APRIL } & \multicolumn{2}{|l|}{ MAY } \\
\hline $\begin{array}{l}1 \\
2 \\
3 \\
4 \\
5\end{array}$ & $\begin{array}{l}612 \\
548 \\
597 \\
619 \\
619\end{array}$ & $\begin{array}{l}585 \\
586 \\
579 \\
564 \\
616\end{array}$ & $\begin{array}{l}59 A \\
587 \\
589 \\
606 \\
618\end{array}$ & $\begin{array}{l}569 \\
592 \\
574 \\
548 \\
572\end{array}$ & $\begin{array}{l}556 \\
536 \\
528 \\
530 \\
548\end{array}$ & $\begin{array}{l}564 \\
562 \\
552 \\
538 \\
560\end{array}$ & $\begin{array}{l}497 \\
504 \\
533 \\
542 \\
597\end{array}$ & $\begin{array}{l}476 \\
493 \\
494 \\
520 \\
544\end{array}$ & $\begin{array}{l}486 \\
499 \\
514 \\
532 \\
567\end{array}$ & $\begin{array}{l}583 \\
586 \\
537 \\
536 \\
530\end{array}$ & $\begin{array}{l}554 \\
508 \\
511 \\
514 \\
508\end{array}$ & $\begin{array}{l}572 \\
562 \\
528 \\
528 \\
522\end{array}$ \\
\hline $\begin{array}{r}6 \\
7 \\
8 \\
9 \\
10\end{array}$ & $=-$ & 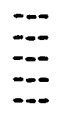 & 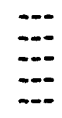 & $\begin{array}{l}574 \\
572 \\
569 \\
564 \\
569\end{array}$ & $\begin{array}{l}569 \\
564 \\
559 \\
543 \\
537\end{array}$ & $\begin{array}{l}571 \\
567 \\
564 \\
555 \\
554\end{array}$ & $\begin{array}{l}604 \\
601 \\
595 \\
575 \\
569\end{array}$ & $\begin{array}{l}578 \\
590 \\
576 \\
565 \\
558\end{array}$ & $\begin{array}{l}595 \\
595 \\
587 \\
569 \\
564\end{array}$ & $\begin{array}{l}529 \\
528 \\
541 \\
562 \\
573\end{array}$ & $\begin{array}{l}503 \\
510 \\
526 \\
545 \\
561\end{array}$ & $\begin{array}{l}519 \\
522 \\
536 \\
554 \\
566\end{array}$ \\
\hline $\begin{array}{l}11 \\
12 \\
13 \\
14 \\
15\end{array}$ & $\begin{array}{l}-1- \\
571 \\
577 \\
57 A \\
579\end{array}$ & $\begin{array}{l}-2- \\
578 \\
569 \\
562 \\
571\end{array}$ & $\begin{array}{l}-5- \\
563 \\
572 \\
574 \\
575\end{array}$ & $\begin{array}{l}572 \\
540 \\
532 \\
521 \\
537\end{array}$ & $\begin{array}{l}521 \\
523 \\
504 \\
508 \\
513\end{array}$ & $\begin{array}{l}546 \\
531 \\
520 \\
514 \\
523\end{array}$ & $\begin{array}{l}568 \\
567 \\
569 \\
565 \\
567\end{array}$ & $\begin{array}{l}552 \\
554 \\
556 \\
549 \\
548\end{array}$ & $\begin{array}{l}561 \\
560 \\
564 \\
560 \\
560\end{array}$ & \begin{tabular}{l}
574 \\
\hdashline 513 \\
572 \\
572
\end{tabular} & $\begin{array}{l}574 \\
-0 . \\
519 \\
557\end{array}$ & $\begin{array}{l}574 \\
-20 \\
568 \\
563\end{array}$ \\
\hline $\begin{array}{l}16 \\
17 \\
18 \\
19 \\
20\end{array}$ & $\begin{array}{l}582 \\
599 \\
589 \\
574 \\
-.-\end{array}$ & $\begin{array}{l}572 \\
575 \\
562 \\
574 \\
---\end{array}$ & $\begin{array}{l}575 \\
587 \\
577 \\
574 \\
-\end{array}$ & $\begin{array}{l}530 \\
523 \\
510 \\
376 \\
489\end{array}$ & $\begin{array}{l}510 \\
510 \\
376 \\
337 \\
398\end{array}$ & $\begin{array}{l}520 \\
516 \\
472 \\
349 \\
453\end{array}$ & $\begin{array}{l}561 \\
549 \\
541 \\
536 \\
544\end{array}$ & $\begin{array}{l}538 \\
531 \\
526 \\
527 \\
535\end{array}$ & $\begin{array}{l}552 \\
540 \\
533 \\
532 \\
539\end{array}$ & $\begin{array}{l}570 \\
574 \\
564 \\
560 \\
559\end{array}$ & $\begin{array}{l}547 \\
558 \\
548 \\
547 \\
537\end{array}$ & $\begin{array}{l}559 \\
565 \\
558 \\
553 \\
549\end{array}$ \\
\hline $\begin{array}{l}21 \\
? 2 \\
23 \\
24 \\
25\end{array}$ & 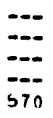 & $\bar{~}=-$ & $\overline{-0}$ & $\begin{array}{l}524 \\
504 \\
472 \\
500 \\
535\end{array}$ & $\begin{array}{l}456 \\
397 \\
429 \\
447 \\
511\end{array}$ & $\begin{array}{l}492 \\
460 \\
449 \\
411 \\
523\end{array}$ & $\begin{array}{l}543 \\
537 \\
525 \\
529 \\
521\end{array}$ & $\begin{array}{l}532 \\
518 \\
510 \\
514 \\
500\end{array}$ & $\begin{array}{l}538 \\
529 \\
518 \\
523 \\
515\end{array}$ & $\begin{array}{l}547 \\
539 \\
544 \\
541 \\
-\end{array}$ & $\begin{array}{l}532 \\
531 \\
536 \\
537 \\
--0\end{array}$ & $\begin{array}{l}539 \\
536 \\
540 \\
539 \\
-5-\end{array}$ \\
\hline $\begin{array}{l}26 \\
27 \\
28 \\
29 \\
30 \\
31\end{array}$ & $\begin{array}{l}58.3 \\
579 \\
571 \\
--- \\
---\end{array}$ & \begin{tabular}{l}
558 \\
561 \\
564 \\
\hdashline- \\
--
\end{tabular} & \begin{tabular}{l}
572 \\
570 \\
566 \\
-- \\
\hdashline- \\
-
\end{tabular} & $\begin{array}{l}592 \\
569 \\
553 \\
509 \\
454 \\
474\end{array}$ & $\begin{array}{l}489 \\
548 \\
502 \\
406 \\
430 \\
446\end{array}$ & $\begin{array}{l}547 \\
556 \\
521 \\
456 \\
445 \\
459\end{array}$ & $\begin{array}{l}518 \\
-0- \\
577 \\
--0\end{array}$ & $\begin{array}{r}497 \\
-0 . \\
564 \\
-0 . \\
-\end{array}$ & $\begin{array}{l}509 \\
--0 \\
-56 \\
---\end{array}$ & 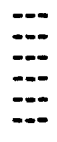 & $\begin{array}{l}=-\infty \\
=-\infty \\
=-\infty \\
=-\infty\end{array}$ & $=$ \\
\hline MONTH & 619 & 521 & 5A1 & 592 & 337 & 514 & 604 & 476 & 545 & 586 & 503 & 548 \\
\hline
\end{tabular}

SPECIFIC CONDUCTANCE (MICROMHOS/CM AT 25 DEG. CI, WATER YEAR OCTOBER 1978 TO SEPTEMBER 1979

\begin{tabular}{|c|c|c|c|}
\hline DAY & $\operatorname{MAX}$ & $\begin{array}{l}\text { MIN } \\
\text { JIINE }\end{array}$ & MEAN \\
\hline 1 & $-\infty$ & -- & -- \\
\hline 2 & $=$ & $-\infty$ & $\cdots$ \\
\hline 3 & $\cdots$ & $m$ & - \\
\hline 4 & $\cdots$ & $\cdots$ & -- \\
\hline 5 & $\cdots$ & $-\infty$ & - \\
\hline 6 & $-\infty$ & $m$ & $\cdots$ \\
\hline 7 & $=-$ & $=-$ & $-\infty$ \\
\hline A & 572 & 553 & 564 \\
\hline 9 & 569 & 553 & 563 \\
\hline 10 & 558 & 520 & 531 \\
\hline 11 & 535 & 522 & 530 \\
\hline 12 & 526 & 511 & 521 \\
\hline 13 & 513 & 504 & 510 \\
\hline 14 & 510 & 495 & 504 \\
\hline 15 & 506 & $4 B 6$ & 497 \\
\hline 16 & 504 & 403 & 496 \\
\hline 17 & 499 & 488 & 494 \\
\hline 18 & $49 ?$ & 488 & 490 \\
\hline 19 & 501 & 488 & 494 \\
\hline 20 & 499 & 485 & 493 \\
\hline 21 & 507 & 487 & 497 \\
\hline 72 & $\cdots$ & $\cdots$ & -- \\
\hline 23 & -- & $=-$ & $-\cdots$ \\
\hline 24 & $\cdots$ & $\cdots$ & $\cdots$ \\
\hline 7.5 & $\cdots$ & -- & $-\infty$ \\
\hline 26 & -- & $-\infty$ & -- \\
\hline 27 & -- & $\cdots$ & -- \\
\hline 28 & $-\infty$ & $\cdots$ & - \\
\hline 29 & $\cdots$ & -- & $-\infty$ \\
\hline 30 & $m$ & $\cdots$ & - \\
\hline 31 & -- & $-\infty$ & -- \\
\hline MONTH & 572 & 485 & 513 \\
\hline YE & 65 & 272 & \\
\hline
\end{tabular}

MAX MIN MEAN

JIJY

(2)

MAX MIN MEAN
AUGUST

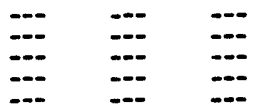

$624 \quad 572 \quad 619$

$\begin{array}{lll}624 & 572 & 619 \\ 628 & 619 & 625 \\ 619 & 528 & 567 \\ 597 & 272 & 439 \\ 541 & 350 & 478\end{array}$

589
631
654
612

654
612
626

635

035
517
555

517
555
593

593
612

618
637
614
608

608
592

588
572
575
558

558
544
536

654
572

572
620
577
601

577
601

462

462
395
410

310
580

580
539

$611 \quad 614$

$\begin{array}{ll}578 & 606 \\ 611 & 613\end{array}$

$\begin{array}{ll}595 & 601 \\ 580 & 585\end{array}$

$577 \quad 582$

$\begin{array}{ll}564 & 568 \\ 566 & 570\end{array}$

566
536
539

539
528

272
478

584
626
612
609

609
616

488
495
509

495
509
586

586
572

570
547
542

532

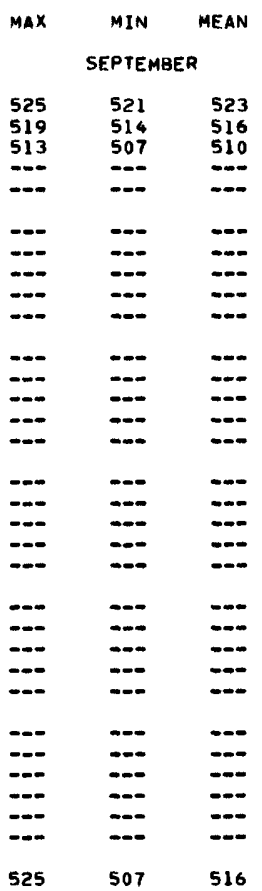

NOTE: NUMMEER OF MISSING DAYS OF KECORD EXCEEDED 20\% OF YEAR 